\title{
Natalizumab for relapsing remitting multiple sclerosis (Review)
}

\author{
Pucci E, Giuliani G, Solari A, Simi S, Minozzi S, Di Pietrantonj C, Galea I
}

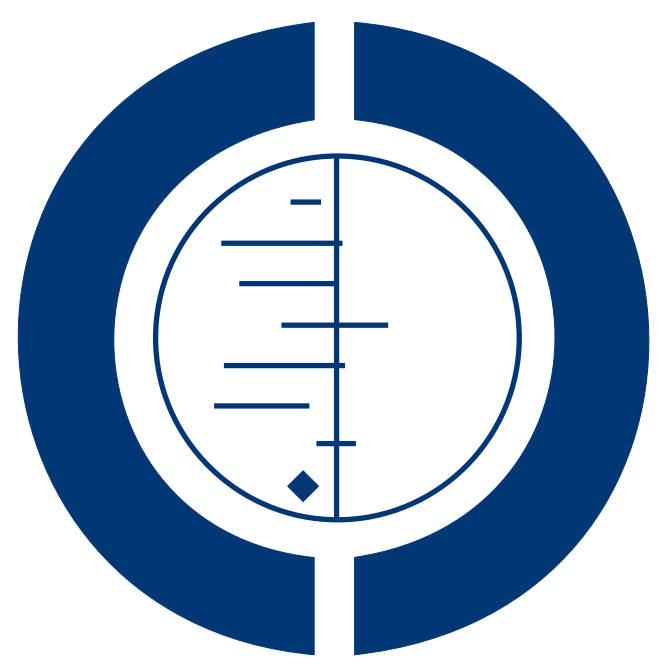

THE COCHRANE
COLLABORATION $^{\circledR}$

This is a reprint of a Cochrane review, prepared and maintained by The Cochrane Collaboration and published in The Cochrane Library 2011, Issue 10

http://www.thecochranelibrary.com

\section{WILEY}




\section{TABLE OF CONTENTS}

HEADER . . . . . . . . . . . . . . . . . . . . . . . . . . . . . . . . . . . . . . . . 1

ABSTRACT . . . . . . . . . . . . . . . . . . . . . . . . . . . . . . . . . . . . . . . 1

PLAIN LANGUAGE SUMMARY . . . . . . . . . . . . . . . . . . . . . . . . . . . . . . . . . . . 2

BACKGROUND . . . . . . . . . . . . . . . . . . . . . . . . . . . . . . . . . . . . . 3

OBJECTIVES . . . . . . . . . . . . . . . . . . . . . . . . . . . . . . . . . . . . . . . . . . . . 44

METHODS .. . . . . . . . . . . . . . . . . . . . . . . . . . . . . . . . . . . . . . . . . .

RESULTS . . . . . . . . . . . . . . . . . . . . . . . . . . . . . . . . . . . . . . . . . . . . .

Figure 1. . . . . . . . . . . . . . . . . . . . . . . . . . . . . . . . . . . . . . . .

Figure 2. . . . . . . . . . . . . . . . . . . . . . . . . . . . . . . . . . . . . .

DISCUSSION . . . . . . . . . . . . . . . . . . . . . . . . . . . . . . . . . . . . . . 12

AUTHORS' CONCLUSIONS . . . . . . . . . . . . . . . . . . . . . . . . . . . . . . . . . . . . . . . . 18

ACKNOWLEDGEMENTS . . . . . . . . . . . . . . . . . . . . . . . . . . . . . . . . . . . 19

REFERENCES . . . . . . . . . . . . . . . . . . . . . . . . . . . . . . . . . . . . . . . 19

CHARACTERISTICS OF STUDIES . . . . . . . . . . . . . . . . . . . . . . . . . . . . . . . . . . . . . . $\quad 26$

DATA AND ANALYSES . . . . . . . . . . . . . . . . . . . . . . . . . . . . . . . . . . . . . . . . . 33

Analysis 1.1. Comparison 1 Primary Efficacy Outcome (Natalizumab vs Control), Outcome $1 \mathrm{~N}$ of pts with at least one relapse at 2 yrs. . . . . . . . . . . . . . . . . . . . . . . . . . . . . . . . . . . . . . . . . . .

Analysis 1.2. Comparison 1 Primary Efficacy Outcome (Natalizumab vs Control), Outcome $2 \mathrm{~N}$ of pts who progressed at 2 yrs. . . . . . . . . . . . . . . . . . . . . . . . . . . . . . . . . . . . . . . . . 39

Analysis 1.3. Comparison 1 Primary Efficacy Outcome (Natalizumab vs Control), Outcome 3 PCS Change in Short Form (SF-36) follow up 2 years.

Analysis 1.4. Comparison 1 Primary Efficacy Outcome (Natalizumab vs Control), Outcome 4 MCS Change in Short Form (SF-36) follow up 2 years.

Analysis 2.1. Comparison 2 Secondary Efficacy Outcome (Natalizumab vs Control), Outcome 1 Change in Well-being (VAS) at 2 yrs.

Analysis 2.2. Comparison 2 Secondary Efficacy Outcome (Natalizumab vs Control), Outcome 2 Gd-enhacing lesion (at least one) at 2 yrs. . . . . . . . . . . . . . . . . . . . . . . . . . . . . . . . . . . . . . . . . . .

Analysis 2.3. Comparison 2 Secondary Efficacy Outcome (Natalizumab vs Control), Outcome 3 Change of MRI T2 total lesion load at 2 yrs.

Analysis 3.1. Comparison 3 Primary Safety Outcome (Natalizumab vs Control), Outcome $1 \mathrm{~N}$ of pts with Severe AE over 2 yrs.

Analysis 3.2. Comparison 3 Primary Safety Outcome (Natalizumab vs Control), Outcome $2 \mathrm{~N}$ of pts with Serious AE (irrespective of treatment duration).

Analysis 3.3. Comparison 3 Primary Safety Outcome (Natalizumab vs Control), Outcome $3 \mathrm{~N}$ of pts with serious AE (irrespective of treatment duration - MS relapses excluded).

Analysis 4.1. Comparison 4 Secondary Safety Outcome (Natalizumab vs Control), Outcome $1 \mathrm{~N}$ of pts with at least one $\mathrm{AE}$ (irrespective of treatment duration).

Analysis 4.2. Comparison 4 Secondary Safety Outcome (Natalizumab vs Control), Outcome 2 Treatment Discontinuation caused by $\mathrm{AE}$ (irrespective of treatment duration).

Analysis 5.1. Comparison 5 Adverse Event Analysis, Outcome 1 Headache. . . . . . . . . . . . . . . . 50

Analysis 5.2. Comparison 5 Adverse Event Analysis, Outcome 2 Pain in arms or legs - Arthralgia. . . . . . . . . 51

Analysis 5.3. Comparison 5 Adverse Event Analysis, Outcome 3 Depression. . . . . . . . . . . . . . . . . 52

Analysis 5.4. Comparison 5 Adverse Event Analysis, Outcome 4 Anxiety. . . . . . . . . . . . . . . . . . . . 53

Analysis 5.5. Comparison 5 Adverse Event Analysis, Outcome 5 Insomnia. . . . . . . . . . . . . . . . . . . 53

Analysis 5.6. Comparison 5 Adverse Event Analysis, Outcome 6 Influenza Like Illness. . . . . . . . . . . . . . 54

Analysis 5.7. Comparison 5 Adverse Event Analysis, Outcome 7 Nasopharyngitis. . . . . . . . . . . . . . . 55

Analysis 5.8. Comparison 5 Adverse Event Analysis, Outcome 8 Pharyngitis. . . . . . . . . . . . . . . . . . 56

Analysis 5.9. Comparison 5 Adverse Event Analysis, Outcome 9 Sinusitis. . . . . . . . . . . . . . . . . 57

Analysis 5.10. Comparison 5 Adverse Event Analysis, Outcome 10 Sinus Congestion. . . . . . . . . . . . . . . 58

Analysis 5.11. Comparison 5 Adverse Event Analysis, Outcome 11 Sinus Headache. . . . . . . . . . . . . . . 58

Analysis 5.12. Comparison 5 Adverse Event Analysis, Outcome 12 Upper Respiratory Infection. . . . . . . . . . . $\quad$. 59

Natalizumab for relapsing remitting multiple sclerosis (Review)

Copyright @ 201 I The Cochrane Collaboration. Published by John Wiley \& Sons, Ltd. 
Analysis 5.13. Comparison 5 Adverse Event Analysis, Outcome 13 Influenza. . . . . . . . . . . . . . .

Analysis 5.14. Comparison 5 Adverse Event Analysis, Outcome 14 Cough. . . . . . . . . . . . . . . . . . .

Analysis 5.15. Comparison 5 Adverse Event Analysis, Outcome 15 Diarrhea. . . . . . . . . . . . . . . . . .

Analysis 5.16. Comparison 5 Adverse Event Analysis, Outcome 16 Nausea. . . . . . . . . . . . . . . . . . .

Analysis 5.17. Comparison 5 Adverse Event Analysis, Outcome 17 Vomiting. . . . . . . . . . . . . . . . . . .

Analysis 5.18. Comparison 5 Adverse Event Analysis, Outcome 18 Abdominal Pain or Discomfort. . . . . . . .

Analysis 5.19. Comparison 5 Adverse Event Analysis, Outcome 19 Muscle Cramp. . . . . . . . . . . . . . . .

Analysis 5.20. Comparison 5 Adverse Event Analysis, Outcome 20 Myalgia. ． . . . . . . . . . . . . . . . .

Analysis 5.21. Comparison 5 Adverse Event Analysis, Outcome 21 Seasonal Allergy. . . . . . . . . . . . . . . . .

Analysis 5.22. Comparison 5 Adverse Event Analysis, Outcome 22 Peripheral Edema. . . . . . . . . . . . . .

Analysis 5.23. Comparison 5 Adverse Event Analysis, Outcome 23 Tremor. . . . . . . . . . . . . . . . . .

Analysis 5.24. Comparison 5 Adverse Event Analysis, Outcome 24 Flushing. . . . . . . . . . . . . . . . . . .

Analysis 5.25. Comparison 5 Adverse Event Analysis, Outcome 25 Fatigue - Myasthenia. . . . . . . . . . . . .

Analysis 5.26. Comparison 5 Adverse Event Analysis, Outcome 26 Urinary Urgency / Frequency. . . . . . . . . .

Analysis 5.27. Comparison 5 Adverse Event Analysis, Outcome 27 Hypersensitivity reactions. . . . . . . . . . . .

Analysis 5.28. Comparison 5 Adverse Event Analysis, Outcome 28 Chest Discomfort. . . . . . . . . . . . . . .

Analysis 5.29. Comparison 5 Adverse Event Analysis, Outcome 29 Local Bleeding. . . . . . . . . . . . . . . . .

Analysis 5.30. Comparison 5 Adverse Event Analysis, Outcome 30 Rigors. . . . . . . . . . . . . . . . . .

Analysis 5.31. Comparison 5 Adverse Event Analysis, Outcome 31 Syncope. . . . . . . . . . . . . . . . . .

Analysis 5.32. Comparison 5 Adverse Event Analysis, Outcome 32 Urinary Infection. . . . . . . . . . . . . . .

Analysis 5.33. Comparison 5 Adverse Event Analysis, Outcome 33 Lower Respiratory Infection. . . . . . . . . .

Analysis 5.34. Comparison 5 Adverse Event Analysis, Outcome 34 Tonsillitis. . . . . . . . . . . . . . . . .

Analysis 5.35. Comparison 5 Adverse Event Analysis, Outcome 35 Gastroenteritis. . . . . . . . . . . . . . .

Analysis 5.36. Comparison 5 Adverse Event Analysis, Outcome 36 Vaginitis. . . . . . . . . . . . . . . . . . . . .

Analysis 5.37. Comparison 5 Adverse Event Analysis, Outcome 37 Menstrual disorders. . . . . . . . . . . . .

Analysis 5.38. Comparison 5 Adverse Event Analysis, Outcome 38 Skin Rash. . . . . . . . . . . . . . . . .

Analysis 5.39. Comparison 5 Adverse Event Analysis, Outcome 39 Dermatitis. . . . . . . . . . . . . . . . .

Analysis 5.40. Comparison 5 Adverse Event Analysis, Outcome 40 Pruritus. . . . . . . . . . . . . . . . .

Analysis 5.41. Comparison 5 Adverse Event Analysis, Outcome 41 Vertigo. . . . . . . . . . . . . . . . . .

Analysis 5.42. Comparison 5 Adverse Event Analysis, Outcome 42 Infection. . . . . . . . . . . . . . . . . .

Analysis 5.43. Comparison 5 Adverse Event Analysis, Outcome 43 Infusion reactions. . . . . . . . . . . .

Analysis 5.44. Comparison 5 Adverse Event Analysis, Outcome 44 Back Pain. . . . . . . . . . . . . . . . .

Analysis 5.45. Comparison 5 Adverse Event Analysis, Outcome 45 Fall. . . . . . . . . . . . . . . . .

Analysis 5.46. Comparison 5 Adverse Event Analysis, Outcome 46 Neoplasms. . . . . . . . . . . . . . . . .

Analysis 5.47. Comparison 5 Adverse Event Analysis, Outcome 47 Abnormal liver function tests. . . . . . . .

Analysis 5.48. Comparison 5 Adverse Event Analysis, Outcome 48 Death. . . . . . . . . . . . . . . . . .

Analysis 5.49. Comparison 5 Adverse Event Analysis, Outcome $49 \mathrm{MS}$ relapse as a serious AE. . . . . . . . . . .

ADDITIONAL TABLES . . . . . . . . . . . . . . . . . . . . . . . . . . . . . . . . . .

APPENDICES . . . . . . . . . . . . . . . . . . . . . . . . . . . . . . . . . . . . .

HISTORY . . . . . . . . . . . . . . . . . . . . . . . . . . . . . . . . . . . . . . .

CONTRIBUTIONS OF AUTHORS . . . . . . . . . . . . . . . . . . . . . . . . . . . . . . . . .

DECLARATIONS OF INTEREST . . . . . . . . . . . . . . . . . . . . . . . . . . . . . .

SOURCES OF SUPPORT . . . . . . . . . . . . . . . . . . . . . . . . . . . . . . . . . .

DIFFERENCES BETWEEN PROTOCOL AND REVIEW . . . . . . . . . . . . . . . . . . . . . . . . . 


\section{[Intervention Review]}

\section{Natalizumab for relapsing remitting multiple sclerosis}

Eugenio Pucci ${ }^{1}$, Giorgio Giuliani ${ }^{1}$, Alessandra Solari ${ }^{2}$, Silvana Simi ${ }^{3}$, Silvia Minozzi ${ }^{4}$, Carlo Di Pietrantonj ${ }^{5}$, Ian Galea ${ }^{6}$

${ }^{1}$ U.O. Neurologia - Ospedale di Macerata, ASUR Marche - Zona Territoriale 9, Macerata, Italy. ${ }^{2}$ Neuroepidemiology Unit, Fondazione I.R.C.C.S. - Neurological Institute Carlo Besta, Milan, Italy. ${ }^{3}$ Past Senior Researcher of Institute of Clinical Physiology, Pisa, Italy. ${ }^{4}$ Department of Epidemiology, ASL RM/E, Rome, Italy. ${ }^{5}$ Servizio Regionale di Riferimento per l'Epidemiologia, SSEpi-SeREMI Cochrane Vaccines Field, Azienda Sanitaria Locale ASL AL, Alessandria, Italy. ${ }^{6}$ Division of Clinical Neurosciences, School of Medicine, University of Southampton, Southampton, UK

Contact address: Eugenio Pucci, U.O. Neurologia - Ospedale di Macerata, ASUR Marche - Zona Territoriale 9, Via Santa Lucia, 3 , Macerata, 62100, Italy. eugenio_pucci@yahoo.it.

Editorial group: Cochrane Multiple Sclerosis and Rare Diseases of the Central Nervous System Group.

Publication status and date: New, published in Issue 10, 2011.

Review content assessed as up-to-date: 15 August 2010.

Citation: Pucci E, Giuliani G, Solari A, Simi S, Minozzi S, Di Pietrantonj C, Galea I. Natalizumab for relapsing remitting multiple sclerosis. Cochrane Database of Systematic Reviews 2011, Issue 10. Art. No.: CD007621. DOI: 10.1002/14651858.CD007621.pub2.

Copyright (C) 2011 The Cochrane Collaboration. Published by John Wiley \& Sons, Ltd.

\section{A B S T R A C T}

\section{Background}

Natalizumab (NTZ) $\left(\right.$ Tysabri $\left.^{\circledR}\right)$ is a monoclonal antibody that inhibits leukocyte migration across the blood-brain barrier, thus reducing inflammation in central nervous system, and has been approved worldwide for the treatment of relapsing-remitting multiple sclerosis (RRMS).

\section{Objectives}

To evaluate the efficacy, tolerability and safety of NTZ in the treatment of patients with RRMS.

\section{Search methods}

We searched the Cochrane Multiple Sclerosis Group Trials Register, the Cochrane Central Register of Controlled Trials (CENTRAL, The Cochrane Library, 2010, Issue 1), MEDLINE (PubMed) and EMBASE, all up to 19 February 2010, and bibliographies of papers. Handsearching was carried out. Trialists and pharmaceutical companies were contacted. Furthermore, the websites of US Food and Drug Administration (FDA), the European Medicines Evaluation Agency (EMA) and the National Institute for health and Clinical Excellence (NICE) were also checked.

\section{Selection criteria}

All double-blind, randomised, controlled trials analysing more than a single infusion of NTZ (dosage $>3 \mathrm{mg} / \mathrm{kg}$ intravenous infusion every 4 weeks), also including its use as add-on treatment, versus placebo or other drugs in patients with RRMS. No restrictions on the basis of duration of treatment or length of follow up.

\section{Data collection and analysis}

Three reviewers independently selected articles which met the inclusion criteria. Disagreements were solved by discussion. Two reviewers independently extracted the data and assessed the methodological quality of each trial. Missing data was sought by contacting principal authors and Biogen Idec, through Biogen-Dompé Italia. 


\section{Main results}

Three studies met the inclusion criteria. These included one placebo-controlled trial (942 patients) and two add-on placebo-controlled trials, i.e. one plus glatiramer acetate (110 patients) and the second plus interferon beta-1a (1171 patients).

This review assessed the efficacy, tolerability and safety of NTZ in patients with RRMS. Data was conclusive with respect to efficacy and tolerability, but not safety. As far as efficacy is concerned, the results showed statistically significant evidence in favour of NTZ for all the primary outcomes and for the secondary ones where data was available. NTZ reduced the risk of experiencing at least one new exacerbation at 2 years by about $40 \%$ and of experiencing progression at 2 years by about $25 \%$ as compared to a control group. MRI parameters showed statistical evidence in favour of participants receiving NTZ. Infusion reactions, anxiety, sinus congestion, lower limb swelling, rigors, vaginitis and menstrual disorders were reported as adverse events (AEs) more frequently after NTZ treatment. In this review NTZ was found to be well tolerated over a follow-up period of two years: the number of patients experiencing at least one $\mathrm{AE}$ (including severe and serious AEs) during this period did not differ between NTZ-treated patients and controls. Safety concerns have been raised about Progressive Multifocal Leukoencephalopathy (PML). In the trials included in this review, two cases of PML were encountered: one in a patient who had received 29 doses of NTZ and a second fatal case of PML in another patient after 37 doses of NTZ. Our protocol was insufficient to evaluate PML risk as well as other rare and long-term adverse events such as cancers and other opportunistic infections, which are very important issues in considering the risk/benefit ratio of NTZ.

\section{Authors' conclusions}

Although one trial did not contribute to efficacy results due to its duration, we found robust evidence in favour of a reduction in relapses and disability at 2 years in RRMS patients treated with NTZ. The drug was well tolerated. There are current significant safety concerns due to reporting of an increasing number of PML cases in patients treated with NTZ. This review was unable to provide an up-to-date systematic assessment of the risk due to the maximum 2 year-duration of the trials included. An independent systematic review of the safety profile of NTZ is warranted. NTZ should be used only by skilled neurologists in MS centres under surveillance programs.

All the data in this review came from trials supported by the Pharmaceutical Industry. In agreement with the Cochrane Collaboration policy, this may be considered a potential source of bias.

\section{PLAIN LANGUAGE SUMMARY}

\section{The use of the monoclonal antibody Natalizumab (NTZ) in patients with relapsing remitting multiple sclerosis (RRMS)}

It is currently thought that inflammation is crucial in MS, leading to a disruption in the ability of nerves to conduct impulses. NTZ is the first of a new generation of anti-inflammatory treatments for MS, which is given intravenously every 4 weeks. It is usually prescribed once other drugs have failed or when the disease is rapidly worsening.

The Authors of this review evaluated the efficacy, tolerability and safety of NTZ in patients with RRMS. Among the pertinent literature, 3 studies met the inclusion criteria of methodological quality, comprising a total of 2223 participants. The results show that NTZ treatment reduces the number of patients who experienced relapses and the number of patients who progressed at 2 years. Also Magnetic Resonance scans show evidence of a beneficial effect of NTZ on disease activity.

Although information on adverse events (AEs) was limited, as most participants were followed up for 2 years only, infusion reactions, anxiety, sinus congestion, lower limb swelling, rigors, vaginal inflammation and menstrual disorders were found to be more frequent after NTZ treatment. However, the number of patients experiencing at least one AE (including severe or serious AEs) did not differ between NTZ and control groups. On the contrary, significant safety concerns have been raised regarding Progressive Multifocal Leukoencephalopathy (PML), a rare and often fatal viral disease characterized by damage to the white matter of the brain. In the studies included in this review, PML was reported in 2 patients treated with NTZ for more than 2 years. However, our protocol was insufficient to evaluate PML risk as well as other potential rare and long-term AEs (e.g. cancers and other infections) which are important issues in considering the risk/benefit ratio of NTZ. An independent systematic review of the safety profile of NTZ is warranted. NTZ should be used only by skilled neurologists in MS centres under surveillance programs.

All the data in this review came from studies supported by the Pharmaceutical Industry. In agreement with the Cochrane Collaboration policy, this may be considered a potential source of bias. 


\section{B A C K G R O U N D}

Table 1 lists abbreviations used in the text.

\section{Description of the condition}

Multiple sclerosis (MS) is regarded as the foremost cause of nontraumatic neurologic disability in young adults (Tremlett 2010). MS is notoriously heterogeneous, both clinically and histopathologically (Lucchinetti 1996), and characterised by unpredictability from patient to patient and within a given individual over time. In most cases it begins with episodic, largely reversible neurologic dysfunction, in a pattern termed relapsing-remitting multiple sclerosis (RRMS) (Lublin 1996). A minority of patients (ranging from 10 to $20 \%$ of cases) have benign MS (as defined by no or minimal disability at 10 or 20 years), although this continues to be a controversial issue (Pittock 2007). Natural history studies show that, after about 10 years, about half of people with MS gradually develop permanent disability, which may also include acute relapses; this is known as secondary progressive MS (SPMS) (Weinshenker 1989). After a median of 15-28 years (Weinshenker 1989; Tremlett 2006) from disease onset, a disability milestone equivalent to the use of an assistive walking device is reached. There is an increased risk of death in MS (Tremlett 2010).

Magnetic resonance imaging (MRI) does provide a reflection of the underlying pathology, and it is integrated with clinical and other paraclinical diagnostic methods to facilitate the diagnosis of MS (McDonald 2001; Polman 2005). MRI parameters are used as a surrogate marker of disease activity and/or progression. MRI studies have shown that $\mathrm{T} 2$ lesion burden and contrast enhancing lesions are representative of the active inflammatory component which characterises the relapsing-remitting course, while their correlation with disability is poor (Filippi 2002).

The disease has an adverse and often highly debilitating impact on the quality of life (QoL) of people with MS and their families. Relapses, even when they completely remit, are associated with a level of temporary disability that disrupts working, family and social life. MS, even in its early stages, may undermine patients' confidence, restrict their activity and limit their role in society. Subtle but disabling symptoms (such as fatigue, cognitive disturbances or symptoms in the spectrum of anxiety and mood disorders), may not be easily recognised and taken into consideration.

Although the etiology is largely unknown, it is believed that MS develops in genetically predisposed individuals and that environmental factors play a central role in its pathogenesis based on immune-mediated mechanisms. It is thought that aberrant immune responses to self or foreign antigens initiate and perpetuate inflammation (Frohman 2006). The conventional hypothesis of multiple sclerosis pathogenesis is that inflammation is the primary event, leading to demyelination and subsequent axonal damage. However, the role of inflammation is complex, with both beneficial and deleterious features (Martino 2002). On the other hand, some researchers hypothesise that inflammation is not the primary pathogenic mechanism, that axonal loss occurs early and that a cryptic aetiological agent may cause axonal damage and demyelination, as well as inducing an inflammatory response, which plays a secondary role (Trapp 1998; Maggs 2004).

In summary the current predominant school of thought is that the acute inflammatory process characterises the initial stage of the illness, while progression of disability is more closely related to irreversible damage to myelin and axons. These features have important implications for therapy: strategies that target inflammation will only have a limited influence on progression once patients have entered the progressive phase of the disease.

\section{Description of the intervention}

Natalizumab (NTZ) $\left(\right.$ Tysabri $^{\circledR}$, previously labelled Antegren ${ }^{\circledR}$; Elan Pharmaceuticals Inc., San Diego, CA, and Biogen Idec Inc., Cambridge, MA) is a recombinant humanized monoclonal antibody. It contains human IgG4 ${ }_{K}$ framework regions and the complementary-determining regions of a murine antibody that binds to the $\alpha 4$ chain of $\alpha 4 \beta 1$ integrin. The murine region may result in the generation of neutralizing antibodies or allergic reactions. The human region endows natalizumab with the effector functions of immunoglobulin subclass IgG4, which is the least immune activating amongst the human IgGs. The recommended dose of Tysabri ${ }^{\circledR}$ is $300 \mathrm{mg}$ intravenous (IV) infusion every four weeks (FDA 2004).

Tysabri ${ }^{\circledR}$ was approved by Food and Drug Administration (FDA) for treatment of patients with RRMS on 23 November 2004 after priority review of 1-year data from the two ongoing SENTINEL and AFFIRM trials. Priority review and accelerated approval was determined to be appropriate because of the strength of the efficacy and safety data available at 1 year. Following the recognition of two cases of progressive multifocal leukoencephalopathy (PML) in patients who had been receiving NTZ, Biogen Idec and Elan Pharmaceuticals, in discussions with the FDA, suspended commercialization and clinical trials on 28 February 2005 and started to investigate the relationship between PML and NTZ therapy. A comprehensive clinical, radiological, and laboratory investigation of patients exposed to NTZ in clinical trials (including trials carried on in patients with Crohn Disease - CD) was completed (Yousry 2006). In addition, the 2-year results of SENTINEL and AFFIRM trials were submitted to the FDA in September 2005. On July 2006 marketing of Tysabri ${ }^{\circledR}$ resumed . In the following months, Tysabri ${ }^{\circledR}$ was gradually commercialised worldwide.

\section{How the intervention might work}

Inflammatory lesions in MS appear to arise after activated leucocytes gain access to the CNS from the circulation. Integrins on the surface of leucocytes interact with immunoglobulin superfamily 
proteins on cerebral endothelial cells, facilitating diapedesis across the blood-brain barrier. Examples of integrin / immunoglobulin superfamily pairs are VLA4/VCAM1 and LFA1/ICAM1. NTZ is a monoclonal antibody against $\alpha 4$-integrin (part of VLA4), thus preventing interaction of VLA4- with VCAM1 and, as a consequence, blocking the transmigration of VLA4-expressing leucocytes across the blood-brain barrier (Niino 2006; Ransohoff 2007). In preclinical studies, NTZ reduced disease activity in mice with experimentally induced allergic encephalomyelitis, an animal model of MS (Yednock 1992; Kent 1995).

\section{Why it is important to do this review}

Tysabri ${ }^{\circledR}$ is available in many countries for treating RRMS. As a result of the risk of PML (Yousry 2006), it is generally recommended as second-line therapy in RRMS if a conventional DMD has failed, and in rapidly evolving severe disease (e.g. FDA 2006, EMA 2009, AIFA 2006, NICE 2007). The details of the eligibility criteria vary from country to country. A systematic review to assess the efficacy and side effect profile of NTZ is timely and important.

\section{O B J E C T I VES}

The efficacy, tolerability and safety of NTZ in the treatment of people with RRMS were evaluated.

\section{METHODS}

\section{Criteria for considering studies for this review}

\section{Types of studies}

Double-blind, randomised, controlled trials (RCTs). Trials were not excluded on the basis of duration of treatment (except those involving a single infusion) or length of follow up.

\section{Types of participants}

Patients with RRMS of both gender who met the criteria of Poser (Poser 1983) for clinically definite or laboratory-supported definite MS, or the original / revised McDonald criteria (McDonald 2001, Polman 2005), aged > 17 years.

\section{Types of interventions}

NTZ (dosage $>3 \mathrm{mg} / \mathrm{Kg}$ IV infusion every 4 weeks), also as addon treatment, versus placebo or other drug.

\section{Types of outcome measures}

\section{Primary outcomes}

We assessed the following primary outcome measures:

(1) The number of patients experiencing at least one relapse at 2 years. Definitions of relapse given in the original studies were accepted.

(2) The number of patients who progressed at 2 years. Definitions of progression given in the original studies were accepted. However, we tried to evaluate this outcome using the definition of progression as a persistent worsening of at least one point in EDSS (Kurtzke 1983), recorded outside a relapse and confirmed by a follow-up assessment at six months; a persistent half-point increase was adopted if baseline EDSS was 5.5 or worse.

(3) Mean change in Short Form 36 (SF-36) scores (Ware 1992) at 2 years. The SF-36 is a widely used, generic measure of selfreported health status that consists of 35 items investigating eight domains over the previous month: physical functioning (10 items), social functioning (2 items), physical role limitations (4 items), mental health ( 5 items), emotional role limitations ( 3 items), pain (2 items), energy/vitality ( 4 items), and general health (5 items); one more item (change in health over the previous year) was not used in scoring. Higher scores indicate higher QoL. The scores for the eight domains can be reduced to two composite scores, the Physical Component Summary (PCS) and the Mental Component Summary (MCS), by means of principal component analysis (Ware 1993). These summary scales are computed as standardized scores such that a mean score of 50 (standard deviation [SD], 10) corresponds to that of the general US population.

(4) The number of patients with at least one severe AE during 2 years of treatment. Many terms are used to describe harm associated with healthcare interventions, causing confusion. Thus, we define an "adverse event" as any unfavourable outcome that occurs during or after the study, whether or not related to the study drug, including an exacerbation of a preexisting condition, except for MS progression; we also include hospitalization or death (whatever the cause of both). With respect to their severity, definition of severe $\mathrm{AE}$ given in the original studies was accepted. If not otherwise specified, AEs were defined as severe when leading to withdrawal from the study or discontinuation of treatment without satisfying the definition of serious AE (see below for definition). It may be helpful to remember that the term "severe" refers to the intensity of a particular AE and is not synonymous with "serious", i.e. it refers to tolerability, while "serious" (see below for definition) refers to safety (e.g. a non-serious $\mathrm{AE}$, such as headache, may be severe in intensity as opposed to mild or moderate) (ICH Expert Working Group 1994).

(5) The number of patients with a serious AE (no period restriction). Definitions of serious AE were those reported by the Expert Working Group of the International Conference on Harmonisation of Technical Requirements for Registration of Pharmaceuti- 
cals for Human Use (ICH) (death, life-threatening event, hospitalisation or prolongation of existing hospitalisation, persistent or significant disability) (ICH Expert Working Group 1994), except for the fact that we did not consider permanent or significant disability caused by MS as a serious AE.

\section{Secondary outcomes}

The secondary outcome measures included:

(1) Time to progression of disability at 2 years

(2) Mean change in EDSS score at 2 years

(3) Mean change in Multiple Sclerosis Functional Composite (MSFC - Rudick 2002) at 2 years

(4) The number of patients who were unable to walk without aid (EDSS greater than 5.5) at 2 years

(5) Mean change in Modified Fatigue Impact Scale (MFIS) at 2 years (Kos 2005)

(6) Mean change in well-being as measured by a visual analog scale (VAS) at 2 years

(7) Mean change in PASAT (one of the components of MSFC), which assess cognitive function, at 2 years (Gronwall 1977)

(8) The number of patients experiencing clinically significant worsening of vision at 2 years [defined as two-line (10-letter) reductions in Sloan chart scores, sustained over 12 weeks] (Balcer 2000; Rosser 2003)

(9) The number of patients who showed at least one gadoliniumenhancing lesion at 2 years

(10) The mean change of total lesion load on T2-weighted images at 2 years

(11) The number of patients experiencing at least one AE, no matter whether mild or severe, serious or not (no period restriction)

(12) The number of patients experiencing treatment discontinuation caused by $\mathrm{AE}$

(13) The number of patients experiencing a relapse in the 4 weeks after the first dose of NTZ

\section{Search methods for identification of studies}

A systematic search without language restrictions was conducted to identify all relevant published and unpublished randomised controlled trials.

For additional information about the Group's search strategy please see: Cochrane Multiple Sclerosis Group

\section{Electronic searches}

We searched the following databases

1. Cochrane Multiple Sclerosis Group Trials Register (19 February 2010)

2. The Cochrane Central Register of Controlled Trials (CENTRAL) “The Cochrane Library"(Issue 1, 2010) (Appendix 1)
3. MEDLINE (PubMed) (1966 to 19 February 2010)

(Appendix 2)

4. EMBASE (EMBASE.com) (1988 to 19 February 2010)

(Appendix 3)

\section{Searching other resources}

Handsearching of the references quoted or linked to the identified trials and other papers of interest, congress reports (1998 to February 2010) of the American Academy of Neurology, the American Neurological Association, the American Committee for Treatment and Research in MS, the European Committee for Treatment and Research in MS and the Italian Neurological Society. Contact with researchers who were participating in trials on NTZ; and contact with Biogen or other pharmaceutical companies.

In addition we checked the following sources for trials about NTZ: clinicaltrials.gov (www.clinicaltrials.gov); US Food and Drug Administration (FDA) (www.fda.gov), the European Public Assessment Reports from the European Medicines Evaluation Agency (EMA) (www.emea.eu) and the National Institute for health and Clinical Excellence (NICE) (www.nice.org.uk).

\section{Data collection and analysis}

\section{Selection of studies}

Three reviewers (EP, GG, AS - all MS experts), independently assessed the eligibility of articles for the review. The same reviewers independently scrutinised the full texts of the selected studies and decided which trials met the inclusion criteria. All reviewers assessing the relevance of studies knew the names of the authors, institutions, journal of publication and results when they applied the eligibility criteria. Any disagreement was resolved by discussion.

\section{Data extraction and management}

Two reviewers (EP, IG) extracted the data independently: characteristics of participants, interventions, duration of treatment, length of follow-up, outcome measures, side effects and adverse events. We sought to extract from each RCT the number of patients originally assigned to each treatment group to allow an intention-to-treat analysis, if the trial was not already presented in this way. Disagreement was resolved by discussion amongst all the reviewers. All data was registered on a collection form. Study authors were consulted to resolve controversies and clarify questions, including missing data, which were posed by the two reviewers extracting data. Similar clarifications were sought with Biogen Idec Inc. and Elan Pharmaceuticals Inc, through the Medical Direction of Biogen-Dompè Italy. 


\section{Assessment of risk of bias in included studies}

The risk of bias assessment for RCTs and CCTs was performed as recommended by the Cochrane Handbook (Handbook 5 2008) using a two-part tool addressing seven specific domains: sequence generation and allocation concealment (selection bias), blinding of participants and providers (performance bias), blinding of outcome assessor (detection bias), incomplete outcome data (attrition bias), selective outcome reporting (reporting bias) and other sources of bias. The first part of the tool involves describing what was reported to have happened in the study. The second part of the tool involves assigning a judgement relating to the risk of bias for that entry, in terms of low, high or unclear risk. See Appendix 4 for details.

The domains of sequence generation, allocation concealment (avoidance of selection bias) and selective outcome reporting (avoidance of reporting bias) were addressed in the tool by a single entry for each study.

Blinding of participants, personnel and outcome assessor (avoidance of performance bias and detection bias) were considered separately for both objective and subjective outcomes.

We assessed whether included studies were in line with the CONSORT Statement (Moher 2001), a reflection of the risk for biased estimates of treatment effects (Schulz 1995; Moher 1998). Despite the controversy surrounding the importance of the CONSORT Statement (see "Risk of bias' and 'quality" in Cochrane Handbook for Systematic Reviews of Interventions (Higgins 2008), we felt that adherence to such a statement that aims to improve trial reporting was appropriate.

\section{Measures of treatment effect}

Data was analysed according to an intention-to-treat approach. We analysed dichotomous outcomes by calculating relative risks (RR) for each trial with the uncertainty in each trial being expressed using $95 \%$ confidence intervals $(95 \% \mathrm{CI})$. Difference in means (MD) across trials was used for continuous outcomes.

If not available, standard deviations were obtained from sample size, mean values and $\mathrm{p}$-values.

Where appropriate, we planned to calculate Number Needed to Treat (NNT), i.e. Number Needed to Benefit (NNB) or Number Needed to Harm (NNH), as follows: $N N T=1 /[B R(1-R R)]$, where $\mathrm{BR}$ is the baseline risk (rate of the event in the control group) and $\mathrm{RR}$ is the relative risk resulting from meta analysis.

\section{Assessment of heterogeneity}

The statistic $\mathrm{I}^{2}$ was calculated for each pooled estimate, in order to assess the impact of statistical heterogeneity. $\mathrm{I}^{2}$ may be interpreted as the proportion of total variation among effect estimates that is due to heterogeneity rather than sampling error, and it is intrinsically independent of the number of studies. When $\mathrm{I}^{2}<$ $30 \%$ there is little concern about statistical heterogeneity Higgins
2002; Higgins 2003). We used the random-effect model to take account of the between-study variance in our findings (DerSimonian 1986). A sensitivity analysis was performed if $\mathrm{I}^{2}$ was $30 \%$ or more, comparing results obtained via random- and fixed-effect models.

\section{Data synthesis}

We used Review Manager (RevMan) 2008 to perform meta-analyses of the included studies and displayed the results as forest plots. Descriptive analyses of included and excluded trials were also undertaken.

\section{Subgroup analysis and investigation of heterogeneity}

Subgroup analysis were planned for analysing particular AEs which were pooled with other AEs in a generic label. For example, serious AEs due to MS relapse were analysed separately from other serious AEs.

Possible sources of heterogeneity were explored by subgroup analysis where appropriate.

\section{Sensitivity analysis}

In order to incorporate assessment of risk of bias in the review process we planned to plot intervention effects estimates stratified for risk of bias for each relevant domain. In case of differences in results among studies with different risks of bias, we planned to perform sensitivity analysis excluding studies with high risk of bias.

Many issues suitable for sensitivity analysis are only identified during the review process where the individual peculiarities of the studies under investigation are identified. Thus, we retained the opportunity to carry out other sensitivity analyses during the review process that could affect the overall result and conclusions.

\section{R E S U L T S}

\section{Description of studies}

See: Characteristics of included studies; Characteristics of excluded studies; Characteristics of studies awaiting classification.

\section{Results of the search}

After eliminating duplicates, the number of hits retrieved by the Cochrane Multiple Sclerosis Group systematic search strategy was 251. Eleven articles were considered as potentially eligible after screening of titles and abstracts, with consensus among the reviewers. After study of the full text, with consensus among the reviewers, 10 were confirmed as potentially relevant papers. The article excluded concerned the UK Antegren Study 1999. 
No further studies were identified by handsearching of congress reports and other sources.

At this point, the process of linking multiple reports of the same study was carried out. Four studies were identified. Three identified studies completely satisfied the criteria for inclusion in this review. The fourth study, the INMSTG trial (INMSTG 2003), included participants affected with both RRMS and SPMS, who were randomised to two different doses of NTZ ( 3 or $6 \mathrm{mg}$ per kilogram) or placebo. We contacted the study investigators in order to obtain data on RRMS patients in the placebo arm and in the $6 \mathrm{mg}$ per kilogram arm. The INMSTG trial did not contribute to the metanalysis because we did not receive any data from the investigators; for this reason it was included in "studies awaiting classification" (see Characteristics of studies awaiting classification).

\section{Included studies}

Figure I. Methodological quality graph: review authors' judgements on each methodological quality item presented as percentages across all included studies.

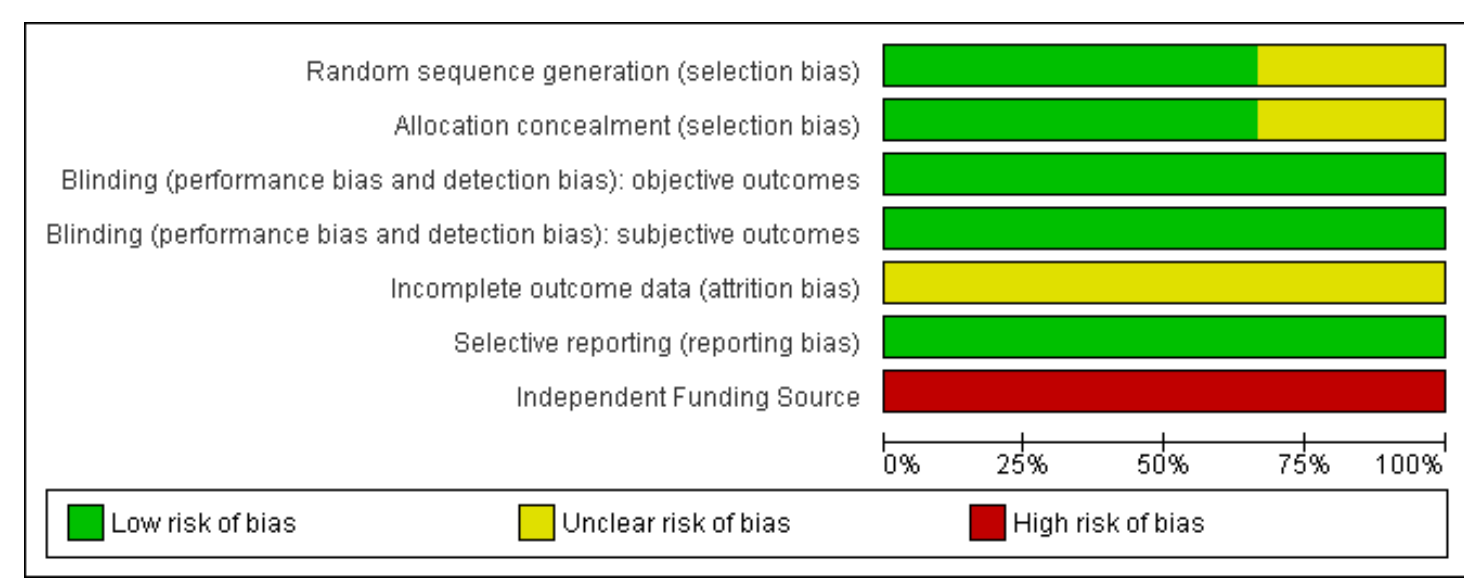

Figure 2 shows authors' judgements on each methodological quality item for each included study.
Three studies met the inclusion criteria: one placebo-controlled trial (942 patients) (AFFIRM 2006) and two add-on placebocontrolled trials, i.e. one plus glatiramer acetate (110 patients) (GLANCE 2009) and the second plus interferon beta-1a (1171 patients) (SENTINEL 2006).

For details see "Characteristics of included studies". Baseline characteristics of participants in the studies which contributed to primary efficacy outcomes are summarised in Table 2.

\section{Excluded studies}

See "Characteristics of excluded studies".

\section{Risk of bias in included studies}

Figure 1 shows authors' judgements on each methodological quality item presented as percentages across all included studies. 
Figure 2. Methodological quality summary: review authors' judgements on each methodological quality item for each included study.

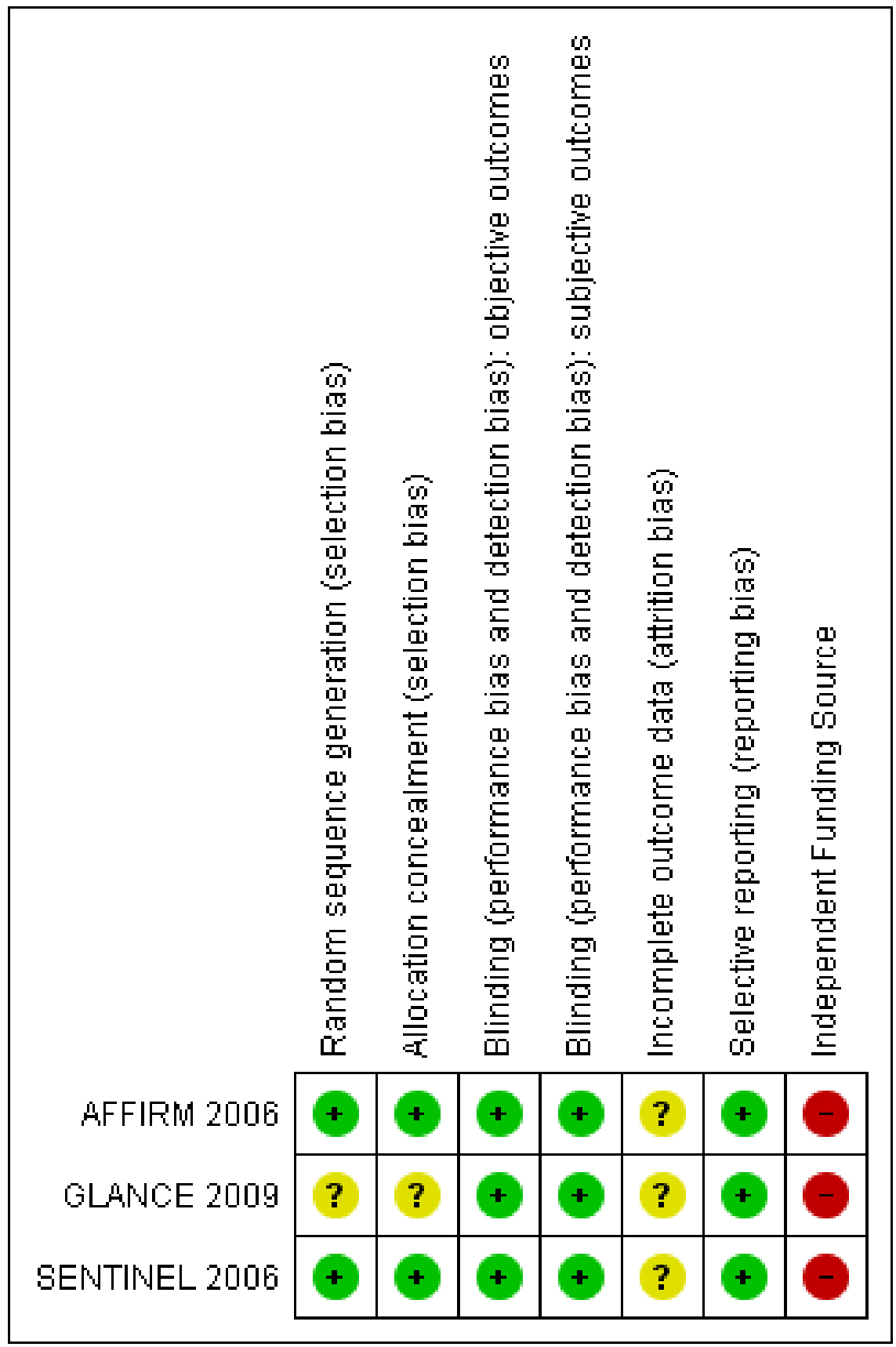


All the data of the present review came from trials supported by Biogen Idec and Elan Pharmaceuticals. All primary references of the included RCTs reported author financial disclosures. Authorindustry ties were reported for $100 \%$ of the authors of the primary reference for each trial. In particular, 4 out of the 14 authors (AFFIRM 2006), 4 out of the 12 authors (GLANCE 2009) and 3 out of the 12 authors (SENTINEL 2006) were employees of Biogen Idec.

Since one of the included trials (SENTINEL 2006), which contributed to primary efficacy outcomes, was an add on study, in which the control arm was placebo plus interferon beta 1a (IFNß1a), one possible risk was underestimation or overestimation of the effect size of NTZ efficacy due to interaction between the DMDs. Results for the NTZ group versus placebo were also reported separately. The use of GA or IFNß-1a in two of the included trials may have biased safety/tolerability outcomes because of interactions between these DMDs and NTZ.

The different durations of included trials could have been a source of bias with respect to secondary safety/tolerability outcomes. To address this concern we performed a sensitivity analysis comparing results including and excluding GLANCE 2009 for tolerability/ safety outcomes, given the short period of follow-up (6 months) in this trial.

Protocol violations may affect results by introducing bias. Data about protocol violations are reported in Table 3, Table 4 and Table 5, and are mainly derived from the FDA's CDER "medical review” (FDA 2004). Unfortunately, the CDER only analysed 1year data from the SENTINEL 2006 and AFFIRM 2006 trials. As far as this 1-year analysis is concerned, the frequency of protocol violations was considered similar for the two treatment arms in both trials.

\section{Allocation}

The AFFIRM 2006 and the SENTINEL 2006 studies had adequate sequence generation and allocation concealment. Randomisation was carried out with the use of a computer-generated schedule and a multidigit identification number, implemented by way of an interactive voice-response system. There was insufficient published information about the method of randomisation and treatment allocation of the GLANCE 2009 trial.

\section{Blinding}

All the included studies were double-blinded.

The occurrence of more frequent AEs in NTZ treated subjects (such as headache during infusion) was not of sufficiently large size to raise concerns about blinding.

A well-established pharmacodynamic feature of NTZ is the increase in number of all circulating leukocytes except neutrophils (Polman 2006 - AFFIRM 2006). The increase of leukocytes was appropriately taken in consideration in blinding procedures, at least in the AFFIRM 2006 and SENTINEL 2006 trials (see below).

Adequacy of double-blinding was appropriate in AFFIRM 2006 and SENTINEL 2006 studies. At each study site, primary and backup examining neurologists (who were not in contact with patients in any other capacity including laboratory assessments) and primary and backup treating neurologists were designated. However, to our knowledge no analyses of the efficacy of blinding was carried out in the included studies.

\section{Incomplete outcome data}

All included studies: (a) reported the percentage of patients who dropped out from the study for each assignment group; (b) reported the percentage of patients who discontinued the treatment but continued follow up (including CONSORT flowcharts); (c) performed the analysis according to the intention-to-treat principle. However, none of the papers described how missing data was imputed for ITT analysis of primary outcomes (the rate of clinical relapse at one year and the rate of sustained progression of disability, as measured by the EDSS, at 2 years). Considering secondary outcomes, the AFFIRM 2006 and SENTINEL 2006 papers reported that missing values were imputed using the mean for the respective measures in the study population. ITT statements with no further details carry a risk of bias. Thus, after resolution of controversy among EP and SM, the methodological quality item "incomplete outcome data addressed" was judged as unclear.

It was not possible to carry out sensitivity analysis to assess the effect of patients who withdrew since raw data was not available to enable an "available case analysis". Data on "the number of patients experiencing at least one relapse" was extracted from Table 2 in Polman 2006 (AFFIRM 2006) and from Table 2 in Rudick 2006 (SENTINEL 2006). In both the tables, looking at the item "Number of relapses - no. of patients", one can see that the total number of patients in each arm is equal to the number of randomised patients (ITT populations), but it is not specified how missing values were included. As far as "the number of patients who progressed" is concerned, data was obtained from the KaplanMeier plots in Figure 2 in Polman 2006 (AFFIRM 2006) and in Figure 2 in Rudick 2006 (SENTINEL 2006).

The percentages of patients who withdrew were low, and similar, between NTZ treated and untreated patients, and the reasons for withdrawal were comparable.

In the AFFIRM trial, the discrepancy between the number of randomised patients $(n=315)$ and the number of patients submitted to safety analysis $(n=312)$ is due to the fact that three patients who were assigned to receive placebo were never treated; these patients were included in the ITT efficacy analyses but were excluded from 
the safety analyses.

MRI data was not available for 8 to $9 \%$ of patients at year 2 in the AFFIRM trial (Miller 2007 - AFFIRM 2006). The main reason for missing data ( $>80 \%$ ) was the scan not being performed because the patient withdrew from the study; in the remainder, although the patient remained in the study, the scan was either not performed, had not been received at the Central MRI Analysis Center, or had been received but was of inadequate quality for analysis (Miller 2007 - AFFIRM 2006).

The SENTINEL 2006 trial was stopped approximately one month early because of 2 reports of PML.

In the SENTINEL 2006 trial 25 patients were excluded from analysis because of irregularities in data (the original enrolled cohort was of 1196 patients while 1171 patients were included in ITT analysis). We did not analyse the effect of this exclusion but the FDA Center for drug evaluation and research (CDER) did, through a "worst case" sensitivity analyses. That analysis did not bring to light significant effects on overall study results at 1 year (FDA 2004a).

\section{Selective reporting}

We did not identify any selective reporting in all the included studies.

\section{Other potential sources of bias}

We did not find any other study characteristics that may have negatively affected the quality of the trials. Except for GLANCE 2009 , papers reported that the studies were overseen by independent data and safety monitoring committees; sample size calculation was performed in all included trials.

Due to the limited number of trials available, we did not perform additional subgroup analyses.

\section{Effects of interventions}

\section{PRIMARY EFFICACY OUTCOME MEASURES}

(1) THE NUMBER OF PARTICIPANTS EXPERIENCING AT LEAST ONE RELAPSE DURING 2 YEARS OF TREATMENT

Data was available from the AFFIRM (Polman 2006, AFFIRM 2006) and SENTINEL (Rudick 2006, SENTINEL 2006) trials for a total of 2113 participants. Relapses were defined as new or recurrent neurologic symptoms not associated with fever or infection, lasting at least 24 hours, and accompanied by new, objective neurologic findings.

The pooled estimate was $\mathrm{RR}=0.57$ ( $95 \%$ CI 0.47 to 0.69 ), showing statistical evidence in favour of NTZ. This result can be reexpressed as follows: NTZ (with or without IFNß-1a) reduced the risk of experiencing at least one new exacerbation at 2 years by $30 \%$ to $50 \%$ as compared to not receiving NTZ.
In order to avoid one patient from experiencing at least one relapse during two years of treatment, 3 to 5 people would have to receive $\mathrm{NTZ}$ (NNB=4, 95\% CI 3 to 5).

There was heterogeneity between the trials $\left(\mathrm{I}^{2}=71 \%\right)$, but no difference was found between fixed-and random-effect models.

(2) THE NUMBER OF PATIENTS WHO PROGRESSED AT 2 YEARS

Data was available from the AFFIRM (Polman 2006, AFFIRM 2006) and SENTINEL (Rudick 2006, SENTINEL 2006) trials for a total of 2113 participants. Definitions of progression given in the original studies were used: in both studies sustained progression of disability was defined as an EDSS increase of 1.0 or more from a baseline score of 1.0 or more, or an EDSS increase of 1.5 or more from a baseline score of 0 that was sustained for 12 weeks (progression could not be confirmed during a relapse).

The pooled estimate was $\mathrm{RR}=0.74$ (95\% CI 0.62 to 0.89 ), showing statistical evidence of efficacy of NTZ in reducing the number of patients who progressed. In other words, NTZ (with or without IFNß-1a) reduced the risk of experiencing progression at 2 years by $10 \%$ to $40 \%$ as compared to a control group not receiving NTZ.

The number of patients needing treatment with NTZ in order to avoid progression in one patient at 2 years is $10(\mathrm{NNB}=10,95 \%$ CI 7 to 23 ).

There was heterogeneity between the trials $\left(\mathrm{I}^{2}=52 \%\right)$, but this was not confirmed in the sensitivity analysis (data not shown).

(3) MEAN CHANGE IN SF-36 SCALE SCORES AT 2 YEARS The PCS and the MCS were analysed separately. Data was available from the AFFIRM and SENTINEL trials (Rudick 2007, SENTINEL 2006, AFFIRM 2006) for a total of 2113 patients.

The mean difference in PCS mean change between the NTZ and control groups favoured NTZ treated patients (MD=1.98, 95\% CI 1.05 to $2.91, \mathrm{p}<0.0001)$. There was no statistical evidence of heterogeneity $\left(\mathrm{I}^{2}=0\right)$.

The mean difference in MCS mean change between NTZ and control groups showed a difference favouring NTZ treated patients $(\mathrm{MD}=1.38,95 \% \mathrm{CI} 0.33$ to $2.42, \mathrm{p}=0.01)$. There was no statistical evidence of heterogeneity $\left(\mathrm{I}^{2}=0\right)$.

\section{SECONDARY EFFICACY OUTCOME MEASURES}

The following measures were planned as secondary efficacy outcome measures in the protocol:

(1) TIME TO PROGRESSION IN DISABILITY AT 2 YEARS

No data was available despite contacting authors and sponsor.

(2) MEAN CHANGE IN EDSS SCORE AT 2 YEARS

No data was available despite contacting authors and sponsor.

(3) MEAN CHANGE IN MSFC AT 2 YEARS

No data was available despite contacting authors and sponsor.

(4) THE NUMBER OF PATIENTS WHO WERE UNABLE

TO WALK WITHOUT AID (EDSS > 5.5) AT 2 YEARS

No data was available despite contacting authors and sponsor. (5) MEAN CHANGE IN MFIS AT 2 YEARS

No data was available despite contacting authors and sponsor. 
(6) MEAN CHANGE IN WELL-BEING AS MEASURED BY A VAS AT 2 YEARS

Data was only available from the AFFIRM trial (Rudick 2007, AFFIRM 2006) for a total of 942 patients.

Mean difference between NTZ and control groups favoured NTZ treatment $(\mathrm{MD}=6.40,95 \% \mathrm{CI} 1.76$ to $11.04, \mathrm{p}=0.007)$.

(7) MEAN CHANGE IN PASAT AT 2 YEARS

No data was available despite contacting authors and sponsor.

(8) THE NUMBER OF PATIENTS EXPERIENCING CLINICALLY SIGNIFICANT WORSENING OF VISION AT 2 YEARS

Clinically significant worsening of vision was defined as two-line (10-letter) reductions in Sloan chart scores, sustained over 12 weeks (Balcer 2000, Rosser 2003). Data from AFFIRM and SENTINEL trials was published in Balcer 2007 (SENTINEL 2006 AFFIRM 2006) but it could not be extracted in a form suitable for the meta-analysis. Data was requested from the authors and sponsor, but no response was received.

(9) THE NUMBER OF PATIENTS WHO SHOWED AT LEAST ONE GADOLINIUM-ENHANCING LESION AT 2 YEARS

Data was available from the AFFIRM (Polman 2006, AFFIRM 2006) and the SENTINEL (Rudick 2006, SENTINEL 2006) trials for a total of 2113 participants.

The number of patients with at least one Gadolinium-enhancing lesion was lower in the NTZ group as compared to the control group ( $R R=0.12,95 \%$ CI 0.09 to 0.17 ). In other words, NTZ (with or without IFNß-1a) reduces the risk of developing at least one Gadolinium-enhancing lesion at 2 years by $87 \%$. NNB is 4 ( $95 \%$ CI 4 to 4$)$. There was no statistical evidence of heterogeneity $\left(\mathrm{I}^{2}=0\right)$.

(10) THE MEAN CHANGE OF TOTAL LESION LOAD ON T2-WEIGHTED IMAGES AT 2 YEARS

Data was available from the AFFIRM trial (Miller 2007, AFFIRM 2006) for 855 patients (91\% from a total of 942). Over 2 years, NTZ significantly reduced the mean change in T2 lesion volume compared with placebo $(\mathrm{MD}=-3796,95 \% \mathrm{CI}-5849.43$ to 1742.97, $\mathrm{p}=0.0003)$.

\section{PRIMARY SAFETY OUTCOMES}

(1) THE NUMBER OF PATIENTS WITH SEVERE AE AT 2 YEARS

Here we report the numbers of patients with a severe AE as reported in the original papers from 2110 RRMS patients over two years [Polman 2006, (AFFIRM 2006) and Rudick 2006, (SENTINEL 2006)]. Number of patients experiencing at least one severe AE did not differ between patients treated with NTZ and controls $\mathrm{RR}=0.92$ (95\% CI 0.81 to 1.04$)$, with no statistical evidence of heterogeneity $\left(\mathrm{I}^{2}=0 \%\right)$.

(2) THE NUMBER OF PATIENTS WITH SERIOUS AE

Serious AE were collected from SENTINEL (Rudick 2006, SENTINEL 2006), AFFIRM (Polman 2006, AFFIRM 2006) and GLANCE (Goodman 2009, GLANCE 2009) trials.
Pooled estimate showed that serious AEs in the NTZ group (227/ 1271 , or $18 \%$ ) were less common than in the control group (199/ 949, or $21 \%$ ): $R R=0.83$ ( $95 \%$ CI 0.70 to 0.98 ). No statistical evidence of heterogeneity was found $\left(\mathrm{I}^{2}=0 \%\right)$. Since serious $\mathrm{AEs}$ prevailed in the control group. NNH was not calculated.

A sensitivity analysis excluding the GLANCE trial which was characterised by lower occurrence of serious AEs ( $2 \%$ in the NTZ arm and $4 \%$ in the control arm over 6 months, vs. $18 \%$ and $21 \%$ [SENTINEL 2006] and 19\% and 24\% [AFFIRM 2006], respectively, over 2 years) did not change findings: $\mathrm{RR}=0.83$ (95\% CI 0.70 to 0.99$)$.

Two cases of PML were included in the serious AEs. They were two participants in the SENTINEL trial who were diagnosed as having PML after their completion of the two-year study (after 29 and 37 doses of NTZ respectively) (Langer-Gould 2005; KleinschmidtDeMasters 2005).

The most common serious AE was a relapse of MS, which was significantly more frequent in controls than in NTZ-treated patients ( $R R=0.50,95 \%$ CI 0.37 to 0.68 ). We speculated that MS relapses were considered as serious AEs because they resulted in hospitalisation (unofficial communication from the Medical Direction of Biogen-Dompé Italia in May 2009). When recalculating serious AEs without including MS relapses, we did not find any statistical difference between NTZ and control groups (RR=1.13, 95\% CI 0.90 to 1.43$)$.

Death occurred in 3 patients in the SENTINEL trial: 2 were assigned to IFNß-1a alone and one was the fatal case of PML after 37 doses of NTZ (Kleinschmidt-DeMasters 2005). Two deaths occurred in the AFFIRM study, both in the NTZ group. One patient died of malignant melanoma. A second patient, a 49 yearold woman, died of alcohol intoxication (Polman 2006, AFFIRM 2006) (a suicide was suspected - unofficial communication from the Medical Direction of Biogen-Dompé Italia in May 2009).

\section{SECONDARY SAFETY OUTCOMES}

We assessed the following secondary safety outcome measures at any time of follow-up:

(1) THE NUMBER OF PATIENTS EXPERIENCING AT LEAST ONE AE

In SENTINEL (Rudick 2006, SENTINEL 2006), AFFIRM (Polman 2006, AFFIRM 2006) and GLANCE (Goodman 2009, GLANCE 2009) trials, the numbers of patients who reported at least one $\mathrm{AE}$ were given.

Number of patients experiencing at least one AE did not differ between patients treated with NTZ and controls $[\mathrm{RR}=1.00(95 \%$ CI 0.99 to 1.01)], with no statistical evidence of heterogeneity (I ${ }^{2}=0 \%$ ).

As far as the type of $\mathrm{AE}$ is concerned, we report those $\mathrm{AE}$ which were significantly different between NTZ-treated and placebotreated patients, as follows:

- In the SENTINEL study, anxiety was statistically more frequent in patients treated with NTZ than in patients who were not $(\mathrm{RR}=1.49,95 \% \mathrm{CI} 1.05$ to 2.12$)$. Data on anxiety was not 
reported in the AFFIRM and GLANCE papers.

- In the SENTINEL study, "sinus congestion" was statistically more frequent in patients treated with NTZ than in patients who were not $(\mathrm{RR}=2.03,95 \% \mathrm{CI} 1.15$ to 3.59). In the AFFIRM and GLANCE studies, the term "sinus congestion" was not reported among the AEs.

- In the SENTINEL study, "peripheral edema” was statistically more frequent in patients treated with NTZ than in patients who were not $(\mathrm{RR}=4.78,95 \%$ CI 2.00 to 11.42$)$. In the AFFIRM and GLANCE papers, the authors did not report the term "peripheral edema" among the AEs.

- "Rigors" were statistically more frequent in patients treated with NTZ than in patients who were not $(R R=3.54,95 \% \mathrm{CI}$ 1.16 to 10.83 ). In the SENTINEL trial (Rudick 2006, SENTINEL 2006) the term "rigors" was not mentioned among the AEs.

- In the AFFIRM study, "vaginitis" was statistically more frequent in women treated with NTZ than in those who were not $(\mathrm{RR}=1.65,95 \% \mathrm{CI} 1.01$ to 2.71$)$. In the SENTINEL (Rudick 2006, SENTINEL 2006) and GLANCE (Goodman 2009, GLANCE 2009) studies the term "vaginitis" was not reported among the AEs.

- In the AFFIRM study, menstrual disorders were statistically more frequent in women treated with natalizumab than in those who were treated with placebo ( $R R=1.89$, 95\% CI 1.09 to 3.29). In the SENTINEL (Rudick 2006, SENTINEL 2006) and GLANCE (Goodman 2009, GLANCE 2009) trials menstrual disorders were not reported among the AEs.

- In the SENTINEL, AFFIRM and GLANCE trials, the numbers of patients who suffered from "infusion reactions" and "hypersensitivity reactions" (HSRs) were reported. "Infusion reactions" were defined as any event that occurred within two hours after the start of the infusion. "Infusion reactions" were more frequent in NTZ-treated patients than in controls $(\mathrm{RR}=$ $1.24,95 \%$ CI 1.05 to 1.47 ). The most common "infusion reaction" was headache. However, when only headache was analysed, no statistical significant difference was found between NTZ-treated participants and controls. HSRs, which are a major concern among clinicians, were more frequent in NTZ-treated patients than in controls but this was not statistically significant ( $\mathrm{RR}=3.43$, 95\% CI 0.33 to 36.07). The term "HSRs" included all conditions defined as "hypersensitivity", "allergic reaction", "anaphylactic/anaphylactoid reaction", "urticaria”, "allergic dermatitis", or "hives". There was, however, heterogeneity among the trials $\left(\mathrm{I}^{2}=65 \%\right)$, and when repeating the comparison with the fixed model, a statistically significant difference was found. Since the most likely source of heterogeneity was the GLANCE trial, the comparison was repeated without the GLANCE data. In this comparison, HSRs were significantly more frequent in NTZ-treated patients without evidence of heterogeneity ( $\mathrm{I}^{2}<30 \%$ using either the random-effect or fixedeffect methods). No cardiovascular or respiratory compromise was associated with any of these events classified as HSRs, except for one patient who received epinephrine and one patient who required supplemental oxygen (both in the AFFIRM 2006 trial, Polman 2006, Phillips 2006). In the AFFIRM study two NTZ patients were re-dosed after experiencing a hypersensitivity reaction (protocol violation); thus, a total of 27 HSRs were observed in 25 NTZ patients (Phillips 2006, AFFIRM 2006).

Since clinically significant liver injury has been reported in patients treated with NTZ in the post-marketing setting (Francis 2008, US FDA 2008), we looked at liver-function tests. The number of patients experiencing an abnormality in liver-function tests was only available in the AFFIRM study (Polman 2006, AFFIRM 2006), without evidence of statistically significant differences between NTZ and placebo groups ( $R R=1.29,95 \%$ CI 0.67 to 2.47 ). In the SENTINEL study (Rudick 2006, SENTINEL 2006) it is stated that "no increase in the incidence of chemical abnormalities, including the results of liver-function tests, was observed with combination therapy"; the same applies for the GLANCE trial (Goodman 2009, GLANCE 2009).

Finally, we pooled data regarding the number of patients with at least one "infection" (irrespective of infection type) and found no evidence of differences between NTZ and placebo groups $(\mathrm{RR}=$ $1.01,95 \%$ CI 0.97 to 1.06 ; $\mathrm{I}^{2}=0 \%$ ).

(2) THE NUMBER OF PATIENTS EXPERIENCING TREATMENT DISCONTINUATION CAUSED BY AE

Data was available for the SENTINEL (Rudick 2006, SENTINEL 2006), AFFIRM (Polman 2006, AFFIRM 2006) and GLANCE (Goodman 2009, GLANCE 2009) trials. The pooled estimate was $\mathrm{RR}=1.14$ (95\% CI 0.82 to 1.59 ), showing no statistical difference in the rate of discontinuation between patients who took NTZ and those who did not; there was no statistical evidence of heterogeneity $\left(\mathrm{I}^{2}=0 \%\right)$. It is important to mention that we encountered difficulty in extracting raw data for this outcome; differences between the review authors were resolved by discussion.

(3) THE NUMBER OF PATIENTS EXPERIENCING A RELAPSE IN THE 4 WEEKS AFTER THE FIRST DOSE OF NTZ

No data was available despite contacting the authors and sponsor.

\section{DISCUSSION}

\section{Summary of main results}

Our results show statistical evidence in favour of NTZ for all the primary efficacy outcome measures and for those secondary efficacy measures for which data was available.

NTZ (with or without IFNß-1a once a week) reduced the risk of experiencing at least one new exacerbation at 2 years by about $40 \%$ and the risk of experiencing progression at 2 years by about $25 \%$ 
as compared to a control group. To reduce the risk of experiencing at least one new exacerbation, 3 to 5 patients need to receive NTZ (with or without IFNß-1a once a week) (NNB=4; 95\% CI 3 to 5). The number of patients needing treatment with NTZ in order to prevent progression in one patient at 2 years is 7 to 23 ( $\mathrm{NNB}=$ $10 ; 95 \%$ CI 7 to 23). It is noteworthy that the effect size is high for both primary outcomes, with NNB of 4 and 10. Confidence intervals show that the estimate is very precise for the risk of at least one new exacerbation, though less so for progression.

NTZ therapy results in significant HRQoL benefits. Both PCS and MCS mean changes favour NTZ-treated patients.

Available data was not suitable for metanalysis of the following secondary efficacy outcome measures: time to progression at 2 years; mean change in EDSS score at 2 years; mean change in MSFC at 2 years; the number of patients who were unable to walk without aid (EDSS > 5.5) at 2 years; mean change in PASAT at 2 years.

Available data was also not suitable for metanalysis of the mean change in MFIS at 2 years. There are some trials included in the trial register ClinicalTrials.gov (accessed 1 April, 2010) aimed at evaluating NTZ for the relief of MS-related fatigue through the MFIS (ENER-G study http://clinicaltrials.gov/ct2/show/ NCT00464074; TYNERGY study - http://clinicaltrials.gov/ ct2/show/NCT00884481 and http://clinicaltrials.gov/ct2/show/ NCT00966797); however these are open label trials with an observation period of less than 2 years. An open label trial indicated significant improvement in MFIS scores after 6 months therapy with NTZ compared to baseline (Putzki 2009). Moreover, preliminary results indicate that MFIS scores decreased (improved) significantly after the third NTZ infusion follow-up, compared to baseline, in an open study of 186 MS patients (Stephenson 2009). We were unable to extract data from the paper by Balcer 2007, which reported results from the AFFIRM 2006 and SENTINEL 2006 trials, in order to assess the number of patients experiencing clinically significant worsening of vision at 2 years. This paper demonstrated reduction in visual loss, as assessed by low-contrast acuity testing, after NTZ treatment.

MRI parameters show statistical evidence in favour of participants receiving NTZ versus controls.

Our analysis indicated that NTZ is well tolerated and safe over a period of up to 2 years.

Serious AEs were less probable in the NTZ group than in the control group. Since this could be due to the fact that the most common serious $\mathrm{AE}$ in included trials was a MS relapse, which was significantly more frequent in controls than in NTZ-treated patients, MS relapses were excluded from the analysis and no difference in serious AEs was found.

We did not find evidence of potential liver injury with NTZ. This problem raised interest in 2008 when a FDA safety review of NTZ identified four cases of serious hepatic injury (http://www.fda.gov/ cder/dsn/2008 spring/ postmarketing.htm\#natalizumab). None of the cases resulted in death or liver transplant. As a consequence, the "Warnings and Precautions" section of the product labelling was updated to reflect this new safety information. Currently, monitoring liver enzymes is recommended before and during treatment with NTZ.

In the NTZ arm of the AFFIRM study, one patient died of malignant melanoma. He had a history of malignant melanoma and had noted a new lesion at the time of receiving the first dose of NTZ. In the literature, other cases of possible association between NTZ and melanoma have been reported (Mullen 2008; Bergamaschi 2009; Ismail 2009; Laroni 2010). Whether this association is real or coincidental remains to be seen.

About PML and other safety issues see "Overall completeness and applicability of evidence".

Not surprisingly, the PML cases have sensitized the neurologic community to potential risks of NTZ, and this could result in over-reporting of concomitant medical problems as potential $\mathrm{AE}$ in NTZ-treated patients.

The number of patients experiencing at least one severe AE during 2 years did not differ between patients treated with NTZ and controls. NTZ may cause HSRs and acute infusion reactions (Cohen 2010) but data emerging from this review is not alarming. Similar to other protein-based therapies, NTZ may trigger these events primarily in the first months of treatment. Most HSRs seem to occur during the second infusion (Berger 2009; Phillips 2006, AFFIRM 2006). HSRs and infusion-related AEs have been correlated with incidence of anti-NTZ antibodies (Calabresi 2007; Cohen 2010). However, some cases of delayed allergic reactions were reported or hypothesised in the absence of anti-NTZ antibodies (Krumbholz 2007; Hellwig 2008; Cohen 2009; Zephir 2009; Killestein 2009).

It was difficult to calculate the number of patients who discontinued the interventions because of AEs in the AFFIRM and SENTINEL trials. Reasons for discontinuation from the study interventions were not available for the patients who "discontinued study drug but completed follow-up" in the "participant flow" figures in the papers Polman 2006 (AFFIRM 2006 - Figure1, page 906) and Rudick 2006 (SENTINEL 2006 - Figure 1, page 915). Therefore, the numbers used in the metanalysis were drawn from percentages reported in the text. No statistically significant difference in rate of discontinuation because of AEs was found between patients who took NTZ and those who did not. It is worth mentioning that patients who experienced any HSR (irrespective of severity) were required by the protocol to discontinue the study drug in the AFFIRM and SENTINEL trials (Biogen Idec and Elan Pharmaceuticals 2006).

A well-established pharmacodynamic feature of NTZ is the increase in number of circulating leukocytes. Counts return to baseline levels when NTZ is discontinued. Thus, the increase in number of leukocytes was not reported among laboratory AEs.

No data was available regarding the number of patients experiencing a relapse in the 4 weeks after the first dose of NTZ. We included this outcome to assess the first-dose paradoxical reaction hypoth- 
esised in some reports (Centonze 2008; Haupts 2008; Haartsen 2009; Rinaldi 2009). It was speculated that NTZ can promote the release of inflammatory mediators from lymphocytes present in the CNS (Centonze 2008) or modify the regulatory network in the brain (Rinaldi 2009) at the time of the first infusion, thus favouring the clinical manifestation of a pre-existing active lesion. A RCT (O'Connor 2004) aimed at evaluating the effects of a single dose of IV NTZ 1 or $3 \mathrm{mg} / \mathrm{kg}(\mathrm{n}=117)$ or placebo $(\mathrm{n}=63)$ within 96 hours of the onset of a MS relapse, found that NTZ did not effect the short-term clinical course of patients during acute relapses; a significant decrease in Gd-enhancing lesion volume was observed at 1 and 3 weeks after treatment. Moreover, there were no differences in the NTZ versus placebo groups in the occurrence of new acute relapses during a 14-week follow-up period.

\section{Overall completeness and applicability of evidence}

The review's aim was to assess NTZ's efficacy, tolerability and safety in patients with RRMS. In our view this review has reliably assessed efficacy and short- and 2 year long-term tolerability and safety.

As far as assessment of progression is concerned, included studies required only 12 weeks of sustained EDSS worsening to classify patient outcome as progression. As stated in the review protocol, the preferred definition of progression included confirmation of sustained EDSS increase at 6 months; one cannot exclude that some patients classified as developing progression may merely have experienced a prolonged but still reversible disability after a relapse and not an actual progression (Ebers 2008).

A limitation in the analysis of the PCS and MCS components of SF-36 is the clinical significance of measured changes. A change of 5.0 points $(\mathrm{SD}, 0.5)$ is considered a clinically meaningful difference in a reference population of disease-free individuals (Norman 2003).

Tysabri ${ }^{\circledR}$ is available in many countries for treating RRMS. It has marketing authorisation or recommendation as a single diseasemodifying therapy in patients with highly active RRMS or patients who have had an inadequate response to, or are unable to tolerate, other current multiple sclerosis therapies (FDA 2006, EMA 2009, AIFA 2006, NICE 2007). The definition of highly active RRMS differs slightly from country to country, but it can be said to include: (i) failure to respond to a full and adequate course of an interferon beta (IFNß - different types) or GA, with at least one significant relapse in the previous year of therapy, and at least $9 \mathrm{~T} 2$ hyperintense lesions on cranial MRI or at least one gadoliniumenhancing lesion; (ii) previously untreated patients with rapidly evolving severe RRMS defined by two or more disabling relapses in 1 year, and 1 or more gadolinium-enhancing lesions on brain MRI or a significant increase in T2 lesion load compared with a previous MRI (EMA 2009, AIFA 2006, NICE 2007). In any case, the variable licensed indications all over the world for the use of NTZ represents a compromise between the need to provide a more effective therapy for RRMS, the risk of PML and the cost of implementation (Giovannoni 2007).

This review did not evaluate the question whether the clinical efficacy of NTZ in the suboptimal therapy group can be considered to be fully established. However, study populations included patients with active MS, with clinical and MRI features similar to those included in prescribing recommendations (even with some differences from country to country). As an example $38 \%$ of patients in the combined SENTINEL 2006 and AFFIRM 2006 cohort had two or more relapses in the preceding year and $41 \%$ had at least one gadolinium enhancing lesion on brain MRI. A post hoc analysis of the AFFIRM study (Havrdova 2009, AFFIRM 2006) showed that NTZ was superior to placebo (absence of disease activity on combined clinical and radiological measures defined as no relapse, no progression of disability sustained for 3 months, no Gd+ lesion, and no new or enlarging T2-hyperintense lesions) in both highly active ( $\geq 2$ relapses in the year before entry and $\geq 1 \mathrm{Gd}+$ lesion at entry) and non-highly active subgroups. Another post hoc analysis of SENTINEL and AFFIRM studies (Hutchinson 2009) found that NTZ reduced the annualised relapse rate and the risk of sustained disability progression regardless of baseline disease or demographic characteristics, except for the subgroup of patients with less than $9 \mathrm{~T} 2$ lesions at baseline. The number of subjects in the subgroup of patients with less than $9 \mathrm{~T} 2$ lesions at baseline is so small ( $8 \%$ of the total population) that any speculation about this result is futile in our opinion.

The primary outcomes of this review were set at 2 years of treatment. No data from RCTs is available for longer treatment duration. However, data from real-world cohorts of RRMS patients who received more than 36 infusions confirm the efficacy of NTZ throughout the 3 years of treatment (O'Connor 2010, Horga 2010, Sangalli 2010). Another open question is the duration of NTZ treatment and the effects of discontinuation. Two studies report that patients who stopped NTZ experienced significant clinical relapses and radiologic worsening within 6 months (West 2010; Killestein 2010). An immune reconstitution inflammatory syndrome (IRIS) - like rebound of inflammatory MS activity after discontinuation is also reported (Miravalle 2011).

What about early treatment? This question was not directly addressed but we can report that patients who participated in AFFIRM 2006 had a median disease duration of 5 yrs (range 0$34 \mathrm{yrs}$ ); 4\% were diagnosed as having MS after a single clinical attack according to McDonald criteria. As protocol violations, 13 patients ( $1.4 \%$ of the total population) in the AFFIRM study were included even if only Clinically Isolated Syndrome (CIS) criteria were satisfied (McDonald 2001). SENTINEL 2006 patients had longer median disease duration (7 yrs; range 1-34 yrs). Thus, one can conclude that NTZ was poorly studied as an early treatment option in RRMS in these studies.

A limitation of this review's external validity is the previous use of DMDs, including immunosuppressants such as cyclophospha- 
mide, mitoxantrone, cyclosporine, azathioprine and methotrexate (some of which are largely used off label in several countries). Only $55 \%$ of the combined SENTINEL 2006 and AFFIRM 2006 cohort (all patients in SENTINEL) had a duration $\geq 10$ months of IFNß therapy before the first dose of NTZ. Precise data on immunosuppressant use prior to inclusion in the trials was not available. Exclusion criteria included treatment with cyclophosphamide or mitoxantrone within the previous year or treatment with cyclosporine, azathioprine or methotrexate within the previous 6 months (Polman 2006, AFFIRM 2006) or with an approved disease-modifying therapy other than IFN $\beta$-1a intramuscularly once weekly within the 12-month period before randomisation (Rudick 2006, SENTINEL 2006). In practice a large number of patients are treated with NTZ after the use of other DMDs, including immunosuppressants and this fact may have an impact on tolerability and safety issues.

Because of the demographic characteristics of the participants in the trials included, the results of this review cannot be considered valid for pediatric RRMS patients (for pediatric use see Ghezzi 2010) and for people with RRMS aged over 55 years or with EDSS $>5$.

Pregnancy or conception planning were exclusion criteria in the RCTs; hence teratogenicity and/or safety of NTZ in pregnancy were not addressed. We can only quote published data on 98 pregnancies, from the TOUCH and TYGRIS studies, showing that exposure to NTZ had no negative effect on pregnancy outcomes (Bozic 2007). Since there is lack of data, NTZ is contraindicated during pregnancy and there is a pregnancy exposure registry for Tysabri sponsored by Biogen Idec \& Elan Pharmaceuticals (http://clinicaltrials.gov/ct2/show/NCT00472992 accessed 9 April 2010).

This review did not intend to evaluate the impact of anti-NTZ antibodies, which develop persistently in about $6 \%$ of treated patients; they are correlated with a higher incidence of AEs, as above mentioned, as well as reduced efficacy (Calabresi 2007).

This review did not compare the efficacy of NTZ with other currently available DMDs in RRMS. Add-on studies are not as directly informative as monotherapy, however they provide evidence of efficacy in a well defined setting. If we assume that IFN $\beta$-1a and NTZ do not interact in a synergistic manner, one might infer from the results of the SENTINEL trial that NTZ appears more efficacious than IFNß-1a once a week (i.e. Avonex) after 2 years of treatment. What DMDs are available as alternatives to Tysabri ${ }^{\circledR}$ in RRMS? In patients with suboptimal response to first line options, it is acceptable to increase the dose if applicable or switch to alternative first line treatments: e.g. high-dose IFN $ß$ if on lowdose IFNß treatment (Panitch 2002; Sharief 2003; Schwid 2005); GA in place of IFNß (Caon 2006; Zwibel 2006) or vice versa. In Italy, and also in other countries, azathioprine and cyclophosphamide are used off-label in MS. Mitoxantrone is approved for MS treatment world-wide (with some differences from country to country), but it is cardiotoxic (Ghalie 2002) and the risk for therapy-related leukaemia is increasingly reported (Straffi 2010). Cross-trial comparisons are very controversial (Freedman 2008; Goodin 2008a; Klawiter 2009). Earnshaw and collaborators, evaluating data for clinical trials and long-term clinical assessments thereafter, found that GA or NTZ in RRMS patients is associated with increased benefits compared with symptom management, albeit at higher costs, and that long-term lifetime cost effectiveness is similar for NTZ and GA (Earnshaw 2009). The best way to avoid any bias is to perform direct head-to-head comparisons of therapies in the same population with adequate randomisation and allocation concealment, clinically meaningful outcomes and statistical power.

Another issue is how well current clinical and MRI criteria for disease activity are measures of response to a particular therapy. Future trials should deal with these issues. The trial entitled "A Multicenter, Randomized, Rater-Blind, Parallel-Group, ActiveControlled Study to Evaluate the Effects of Switching Therapy (Glatiramer Acetate or Interferon B-1a) to NTZ in Subjects With Relapsing Remitting Multiple Sclerosis (SURPASS)" intends to study the outcome of switching to Tysabri ${ }^{\circledR}$ in subjects with active RRMS despite receiving GA or IFNß-1a $\left(\right.$ Rebif $\left.^{\circledR}\right)$ for at least 12 months (http://clinicaltrials.gov/ct2/show/NCT01058005 accessed 9 April 2010). Findings from such a study will provide validation of proposed "activity" criteria, information about the relative benefits of different treatment options with a significant advancement toward optimising treatment in a high-risk MS patient population. IQUALYSEP is a randomised parallel single blind cost-effectiveness trial comparing three years NTZ treatment versus 6 months mitoxantrone treatment followed by immunomodulators for 2.5 years in RRMS defined as "aggressive" ( 1 or more disabling relapses during the 12 months before inclusion; EDSS between 2 and 5) (http://clinicaltrials.gov/ct2/show/ NCT01065727 accessed 9 April 2010).

A major limit of this review is the inability to provide an up-todate systematic assessment of long-term safety. Our protocol was insufficient to evaluate rare and long-term AEs such as PML, cancers and other opportunistic infections, which are very important issues in risk/benefit balancing.

PML is a demyelinating infectious CNS disease, usually observed in immunodeficient patients, especially in AIDS patients, caused by the human polyomavirus JC virus, a common and widespread virus infecting humans (Koralnik 2004; Tan 2010). JC virus has been identified in human post mortem brain samples from immunological normal individuals without PML (White 1992; Mori 1992). The pathogenesis of PML in patients receiving NTZ is complex and not fully understood. PML causes death or severe disability, either directly or as a result of IRIS. This syndrome is an inflammatory response to JC virus associated with a rapid recovery of the immune system after a period of immunosuppression. Therefore, although a cellular immune response directed against the JC virus is beneficial, a rapid global recovery of the immune system might not always be favourable (Tan 2010). The issue of 
PML in MS therapies is not restricted to NTZ. Rituximab is a potentially effective approach in the treatment of RRMS (Hauser 2008). PML occurred during rituximab treatment for hematologic malignancies or autoimmune diseases (e.g. Rheumatoid Arthritis, Systemic Lupus Erythematosus) (Biogen Idec Inc 2008). Azathioprine has been associated with PML in some case reports in different diseases (Schneider 1991, White 2002, Pagnoux 2003, Gedizlioglu 2009). PML has also been described in a NTZ-treated patient with Crohn's disease (Van Assche 2005). NTZ has been approved for CD in USA in January 2008. To our knowledge, there have been no postmarketing reports of PML in patients treated with Tysabri ${ }^{\circledR}$ for CD. Less than $2 \%$ of Tysabri ${ }^{\circledR}$ use in the U.S. has been in patients with CD (US FDA 2009). The FDA, EMEA, Biogen Idec \& Elan Pharmaceuticals continue to receive reports of PML in MS patients treated with Tysabri ${ }^{\circledR}$. The last update obtained from Biogen Idec and Elan Pharmaceuticals dates December 2, 2010 (see http://www.biogenidec.ch accessed 31 December, 2010) when the number of patients with PML was 79 (34 in USA, 40 in Europe and 5 in the rest of the world) of which 16 died (20\%), out of 75500 patients exposed to Tysabri ${ }^{\circledR}$ (exposure as of September 30, 2010). Surviving PML patients have varying levels of disability, ranging from severe to mild. The risk for developing PML in a patient treated with NTZ, initially estimated to be 1:1000 at around 18 months (Yousry 2006), appears now to increase with the number of Tysabri infusions received. On the basis of the total number of patients treated with NTZ and the number of infusions, at 2 December 2010, Biogen Idec \& Elan Pharmaceuticals provided the following treatment epoch risk of PML: $\leq 12$ infusions $=0.01$ per 1000 patients $(95 \% \mathrm{CI}=0$ to 0.07 per 1000$) ; 13-24$ infusions $=0.38$ per 1000 patients $(95 \% \mathrm{CI}=0.23$ to 0.60 per 1000$) ; 25-36$ infusions $=$ 1.48 per 1000 patients ( $95 \% \mathrm{CI}=1.08$ to 1.97 per 1000$)$ and the risk does not seem to increase further after 36 infusions (see http://www.biogenidec.ch accessed 31 December, 2010). It must be noted that around 31000 patients were exposed $\geq 24$ months and $12500 \geq 36$ months to Tysabri ${ }^{\circledR}$ (even this duration may not fully reflect treatment interruptions that may have happened) (see http://www.biogenidec.ch accessed 31 December, 2010). Accumulating experience indicates that a history of prior immunosuppressant use is a risk factor for PML, which appears to be independent of treatment duration. In terms of geographical distribution, the possible higher risk of PML in Europe might be due to greater use of immunosuppressant therapies for MS (Clifford 2010). In February 2010, the FDA provided a safety update that noted an increased risk of getting PML with increasing number of infusions, with the overall worldwide cumulative rate of PML in patients who have received at least 24 infusions estimated as 1.3 cases of PML per 1000 patients. The agency concluded that the benefits of the medicine continue to outweigh the risks (US FDA 2010). The European Medicines Agency (EMA) provided safety updates along similar lines (EMA 2010). Currently, there are no established interventions that can reliably prevent or adequately treat PML, though some are reported (Wenning 2009; Clifford 2010; Warnke 2010). Large-scale, prospective clinical studies are currently under way to determine whether a new JC virus assay will help clinicians predict which patients are most at risk for PML ( STRATIFY-1 and STRATIFY-2). According to Thompson 2008, more than a sevenfold increase in actual risk of PML was required to decrease NTZ's health gain below that of IFNß-1a (Rebif ${ }^{\circledR} 44$ $4 \mathrm{~g})$.

Some controversial safety concerns have been raised in the last few years about opportunistic infections other than PML as a result of prolonged suppression of immunosurveillance of the CNS and other tissues: severe cutaneous Candida infection (Gutwinski 2010), ocular toxoplasmosis (Zecca 2009) and severe herpetic infections (Ransohoff 2007). There was one fatal case of herpes simplex encephalitis (that occurred 3 months after a single dose of NTZ in a patient previously treated with the maximum lifetime dose of mitoxantrone) and one case of herpes simplex meningitis (that developed several hours after a single dose of NTZ) in the post-marketing MS setting (Biogen Idec and Elan Pharmaceuticals 2006). It is currently too difficult to draw conclusions on the causation of these AEs. A single case of cryptosporidial gastroenteritis occurred during the AFFIRM study (the event was considered resolved 70 days after the symptoms first started - Biogen Idec and Elan Pharmaceuticals 2006); this infection may also occur in immunocompetent hosts and, in general, it is a self-limited illness with an average time to recovery ranging from several days up to 5 weeks (Leav 2003).

Other infections (more or less classifiable as opportunistic or atypical) have been reported in CD patients treated with NTZ, including one case each of fatal Pneumocystis carinii pneumonia, fatal Pulmonary aspergillosis, Mycobacterium avium complex pneumonia, cytomegalovirus colitis, cytomegalovirus hepatitis, primary varicella pneumonia, Burkholderia cepacia pneumonia, tubercle bacillus peritonitis, cavitating pneumonia with lung abscess and Candida sepsis (Tysabri CD Briefing Book). It seems that more patients with $\mathrm{CD}$ experienced opportunistic or atypical infections than MS patients during NTZ treatment.

A possible association of NTZ treatment with lymphoma has been postulated. Two cases of primary CNS lymphoma were reported in MS patients: one was Epstein Barr virus negative (Schweikert 2009); for the other case, Epstein Barr virus staining results were not available (Bozic 2009). A systemic B-cell lymphoma has been reported in the ENCORE trial in a patient with CD after NTZ treatment (Targan 2007).

Dysimmune disorders reported in relation to NTZ therapy have been described, including autoimmune thrombocytopenia (Jones 2008) and autoimmune haemolytic anaemia (Outteryck 2009).

As a result of these concerns, mostly PML risk, NTZ is recommended in many countries as second-line therapy if conventional immunomodulatory agents have failed or as first line therapy in severe relapsing disease, as mentioned above (FDA 2004 and 2006, EMA 2009, AIFA 2006, NICE 2007). Immune com- 
petence is crucial before NTZ initiation. Expert recommendations (Gold 2007; Kappos 2007) includes: neutrophils > 1500 cells $/ \mathrm{ml}$, lymphocytes $>1000$ cells $/ \mathrm{ml}$, CD $4+$ cells $>500$ cells $/ \mathrm{ml}$ and CD8+ cells $>250$ cells $/ \mathrm{ml}$; no history of opportunistic infections in the previous 3-6 months; immunosuppressive drugs (except for standard steroid therapy for relapse) should be discontinued at least 6 months before; immunomodulatory agents are contraindicated if concomitant and should be discontinued at least 6 weeks before. The contraindication of simultaneous treatment with immunomodulatory agents and NTZ emerged from the fact that the first 2 cases of PML in MS occurred in patients who were part of the combination treatment arm of the SENTINEL 2006 trial. Beyond these guidelines and recommendations, an important unknown faces the clinician: once a patient is started on NTZ, it is currently unclear how duration of treatment with NTZ impacts the risk-benefit ratio of this drug. The safety issue of NTZ treatment is managed through active post-marketing surveillance programs that are currently being undertaken in several countries. There is the Tysabri Global Observational Program in Safety (TYGRIS) which is a voluntary 5000-patient registry cohort in North America (http://clinicaltrials.gov/ct2/show/ NCT00477113) and the rest of world (http://clinicaltrials.gov/ ct2/show/NCT00483847) with 5-year follow-up for infections requiring hospitalisation, cases of PML, malignancies, and all AEs that are serious or medically significant. The "Tysabri Outreach: Unified Commitment to Health" (TOUCH $\left.{ }^{\circledR}\right)$ is a mandatory prescribing program started by Biogen Idec and Elan Pharmaceuticals in USA with the help of the Food and Drug Administration (FDA) and it is based on the restriction of NTZ prescription to physicians participating in this risk management program (http://www.tysabry.com; http://www.fda.gov/cder/drug/ infopage/natalizumab/RiskMAP.pdf). Reports from the TYGRIS and TOUCH ${ }^{\circledR}$ studies show that the benefit-risk profile of NTZ remains favourable for patients with RRMS (Bozic 2009a). Tysabri Observational Program (TOP) has been planned as an observational program in Europe, Australia and Canada with the primary aim of assessing long-term safety of 5,000 patients treated with Tysabri in RRMS in the post-marketing setting (http:// clinicaltrials.gov/ct2/show/NCT00493298). NTZ is under intensive monitoring by the Medicines and Healthcare products Regulatory Agency (MHRA) accredited by the United Kingdom National Health Service to provide drug safety updates (http:/ /www.mhra.gov.uk). Other examples are the Danish Multiple Sclerosis Treatment Register (Oturai 2009), the Swedish Multiple Sclerosis registry (Piehl 2010), the Australian Prescribing Program (TAPP), and the Italian Agenzia Italiana del Farmaco (AIFA) pharmacovigilance electronic program (www.http://aifaneuro.agenziafarmaco.it; Mancardi 2010). Moreover, STRATA is an ongoing open-label, multinational study evaluating the longterm safety of Tysabri in participants who completed AFFIRM, SENTINEL or GLANCE trials and a dosing suspension safety evaluation, with no history of anti-NTZ antibodies (O'Connor
2010).

Thus, unlike mitoxantrone, for which the actual risks of serious cardiotoxicity and leukaemia only became apparent as case series were published, NTZ has a robust postmarketing safety monitoring program involving a large number of NTZ-treated MS patients worldwide.

From the Cochrane Collaboration point of view, in light of these uncertainties, an independent systematic updated review of the safety profile of NTZ is warranted. Such a review for AEs should be based on different eligibility criteria for selecting studies. The use of different eligibility criteria specifically addresses the problem that RCTs are insufficient to evaluate rare and long-term AEs. AEs may be studied across different indications such as CD, Rheumatoid Arthritis and rare neurological diseases (eg multifocal motor neuropathy - Raji 2009; Susac syndrome - Lee 2009).

\section{Quality of the evidence}

The two larger included studies were classified as having good methodological quality. This is in line with the fact that they also satisfy definition of Class I studies according to the system used by the American Academy of Neurology for therapeutic interventions (Goodin 2008). The quality of evidence for each of the primary outcome measures of the review was good, even if bias could not be definitively excluded (see "Potential biases in the review process"). The two MRI-based secondary outcomes and the other available secondary outcomes confirmed superiority of NTZ treatment, allowing a robust conclusion regarding the main objectives of the review.

Showing both absolute and relative measures for each outcome is a more transparent evaluation of data, considering the different weight that several variables (e.g. frequency of the events studied, baseline patient characteristics, and so on) have on such measures. We accomplished such a need by reporting both RR and NNB values.

\section{Potential biases in the review process}

All relevant studies were identified. The International Natalizumab Multiple Sclerosis Trial Group (INMSTG 2003) was a "study awaiting classification" but we hope to obtain data, from authors or sponsors, for inclusion in pooled data of safety/tolerability outcomes in an updated future version of this review. Seemingly, the exclusion of this data does not effect results on safety/ tolerability.

Single dose trials and trials using dose $\leq 3 \mathrm{mg} / \mathrm{kg}$ were not included in the present review (Table 6), since these are dosages significantly lower than the dosage approved in clinical practice.

Our review is not able to provide data about the possible biasing effect of protocol violations on the results. During the US FDA evaluation process of NTZ in RRMS, the CDER judged the vio- 
lations as minor, stating that they "would not be expected to affect the results directionally” (FDA 2004 - page 38).

We found heterogeneity for the 2 primary outcomes "number of patients who experienced a relapse at 2 yrs" and "number of patients who experienced progression at 2 yrs", but sensitivity analysis did not change conclusions. The heterogeneity may be clearly ascribed to the fact that the SENTINEL 2006 trial was an addon study, with an active treatment control group. Also, AFFIRM 2006 and SENTINEL 2006 populations differed from each other. SENTINEL 2006 had to meet the inclusion criterion of breakthrough disease while on IFNß-1a IM monotherapy. On the other hand, patients who had received treatment with IFNß or GA for more than six months were excluded in AFFIRM 2006.

The type of ITT analysis was not described in the papers reporting included trials. ITT statements with no further details carry an unclear risk of bias.

All the data of the present review was from trials supported by Biogen Idec and Elan Pharmaceuticals. In agreement with Cochrane Collaboration policy, this may be considered as a potential risk of bias. We included Table 6 for the sake of completeness in reporting features of excluded trials which were sponsored.

\section{Agreements and disagreements with other studies or reviews}

Our review is in agreement with other papers which reviewed NTZ (Hutchinson 2007; Yaldizli 2009; Coyle 2009) and with the Report of the Therapeutics and Technology Assessment Subcommittee of the American Academy of Neurology (Goodin 2008). Of notable mention is the post-hoc reassessment of data from the AFFIRM trial made by Havrdova 2009 (AFFIRM 2006) which used as outcome the proportion of patients with absence of disease activity (defined as no relapses, no sustained disability progression, no gadolinium-enhancing lesions, no new or enlarging T2-hyperintense lesions on cranial MRI). This type of outcome could be an increasingly attainable goal in RRMS treatment and could be of interest for future Cochrane reviews.

Several real-life experiences confirm the efficacy and tolerability of NTZ in RRMS (Mancardi 2010, Piehl 2010, Putzki 2010, Putzki 2010a, Belachew 2010, Outteryck 2010, Ghezzi 2010).

\section{Additional comments}

Arriving at the best treatment option for an individual MS patient needs an open and realistic discussion of MS natural history, the therapeutic benefits and risks of each available DMT (paying attention to the insurmountable cross-trial comparison issues), and the patient's own disease history. It is ultimately the patient's decision to refuse or accept the relevant risks related to a treatment. People tend to underestimate common risk and overestimate rare risk. They respond to risks primarily on the basis of emotion rather than facts. They seem to be risk averse when faced with medical interventions, and want information on even the rarest of adverse events (Moore 2008). Denial and other defence mechanisms may make them less capable of weighing pros and cons to a treatment like NTZ. Treatment decisions are based on facts and emotions, both of which may be manipulated. Many factors contribute to an incomplete understanding of the available evidence on risk by both patients and health professionals (Moore 2008). Moreover, studies have revealed communication and information deficits in the context of MS care (Freeman 2000, Vickrey 2000, Heesen 2004, Solari 2007) and heterogeneity in patients' preference in their involvement in decisions regarding their care. As an example, data on Italian MS patients indicates a preference for information but less involvement in decision-making (i.e. more passive role) in more than $30 \%$ of cases (Giordano 2008). These preferences vary from country to country, for example comparing Italian with German MS patients (Giordano 2008). A passive attitude may create a marked difficulty during the decision-making process about a treatment like NTZ. On the contrary, a more active role may be associated with the fact that patients were willing to accept a higher risk of PML than neurologists, and more willing to continue treatment with NTZ as reported by Heesen 2010. Open information about treatment-related risks was appreciated by German MS patients and considered important in supporting shared decision making (Heesen 2010). Although evidence-based medicine strives to reduce medical decision-making to standardized, codified recommendations, it is the judgment of the neurologist and the personal choice of the patient that ultimately determine the treatment plan. Whereas all therapeutic decisions are ultimately in the hands of the patients, their decisions are heavily influenced by the manner in which clinicians present the choices to them. Although the first precept may be "do no harm," if this was taken too far to mean that the risks of all complications should be eliminated, we would be discouraging interventions that on average produce benefits.

More studies about patients' preferences, physicians' communication skills, methodology to enhance communication and patients' evaluation of treatment efficacy and risks are needed. This is not restricted to NTZ, since it is clear that all future therapies that effectively act on the immune system will similarly require analysis of risks and prolonged postmarketing surveillance to determine their safety profiles. As the treatment paradigm of MS evolves and newer agents become available, making treatment decisions and providing skilled guidance for patients will become more challenging for neurologists and health service providers.

\section{AUTHORS'CONCLUSIONS}

\section{Implications for practice}

In patients with RRMS, we found a consistent positive effect of NTZ in reducing relapses and disability at 2 years. NTZ was well tolerated but information on the frequency and nature of AEs was limited to a short follow-up period. There are significant safety 
concerns about PML which is increasingly reported in the postmarketing setting. NTZ should be used only by skilled neurologists in MS centres under national or international surveillance programs.

\section{Implications for research}

Because of safety concerns and the substantial expense related to NTZ, future research should be aimed at:

- further study of the use of NTZ in suboptimal therapy RRMS patients;

- comparing benefit/risk and cost-effectiveness profiles between NTZ and current agents in naive RRMS patients through head-to-head trials;

- comparing benefit/risk and cost-effectiveness profiles through head to head trials between NTZ and new emerging agents in RRMS;

- development and validation of clinical and MRI criteria for reliably assessing disease activity in treatment trials;

- cohort studies investigating predictive parameters of longterm NTZ effectiveness in clinical practice;

- exploring the possible detrimental first-dose effect on relapse, including its prevention;
- investigating and optimising the use of NTZ as induction therapy, with the minimum number of infusions to reduce the risk of PML;

- further study of the risk of PML, other opportunistic infections and cancer during NTZ treatment, evaluating risk threshold on the basis of the number of infusions;

- identifying risk factors for PML at baseline and during treatment;

- optimising best practice to monitor patients during NTZ therapy to facilitate early diagnosis of PML;

- further study on the optimum duration of NTZ treatment;

- assessing the best options for treating PML and IRIS in MS patients exposed to NTZ;

- evaluating the cost-effectiveness of increasing the current 4 week time interval between infusions;

- enhancing strategies for decision making and patient empowerment.

\section{ACKNOWLEDGEMENTS}

We thank Deirdre Beecher, Liliana Coco and Dr. Graziella Filippini - Cochrane Multiple Sclerosis Review Group.

\section{R E F E R E N C E S}

\section{References to studies included in this review}

\section{AFFIRM 2006 \{published data only\}}

Balcer LJ, Galetta SL, Calabresi PA, Confavreux C, Giovannoni G, Havrdova E, et al.Natalizumab reduces visual loss in patients with relapsing multiple sclerosis. Neurology 2007;68:1299-304.

Havrdova E, Galetta S, Hutchinson M, Stefoski D, Bates $\mathrm{D}$, Polman $\mathrm{CH}$, et al.Effect of natalizumab on clinical and radiological disease activity in multiple sclerosis: a retrospective analysis of the Natalizumab Safety and Efficacy in Relapsing-Remitting Multiple Sclerosis (AFFIRM) study. Lancet neurology 2009;8:254-60.

Miller DH, Soon D, Fernando KT, MacManus DG, Barker GJ, Yousry TA, et al.MRI outcomes in a placebo controlled trial of natalizumab in relapsing MS. Neurology 2007;68: 1390-401.

Phillips JT, O'Connor PW, Havrdova E, Hutchinson M, Kappos L, Miller DH, et al.Infusion-related hypersensitivity reactions during natalizumab treatment. Neurology 2006; 67:1717-8. [DOI: 10.1212/01.wnl.0000242629.66372; : Erratum in Neurology 2007; 68:473]

* Polman CH, O'Connor PW, Havrdova E, Hutchinson
M, Kappos L, Miller DH, et al.A Randomized placebocontrolled trial of Nataluzimab for relapsing multiple sclerosis. NEJM 2006;354(9):899-910.

Rudick RA, Miller D, Hass S, Hutchinson M, Calabresi PA, Confavreux C, et al.Health related quality of life in multiple sclerosis: effects of natalizumab. Annals of Neurology 2007; 62(4):335-46.

GLANCE 2009 \{published data only\}

* Goodman AD, Rossman H, Bar-Or A, Miller A, Miller $\mathrm{DH}$, Schmierer K, et al.GLANCE: Results of a phase 2, randomized, double-blind, placebo-controlled study. Neurology 2009;72:806-12.

SENTINEL 2006 \{published data only\} Balcer LJ, Galetta SL, Calabresi PA, Confavreux C, Giovannoni G, Havrdova E, et al.Natalizumab reduces visual loss in patients with relapsing multiple sclerosis. Neurology 2007;68:1299-304.

Rudick RA, Miller D, Hass S, Hutchinson M, Calabresi PA, Confavreux $\mathrm{C}$, et al.Health related quality of life in multiple sclerosis: effects of natalizumab. Annals of Neurology 2007; 62:335-46.

* Rudick RA, Stuart WH, Calabresi PA, Confavreux C, 
Galetta SL, Radue EW, et al.Natalizumab plus interferon beta-1a for relapsing multiple sclerosis. NEJM 2006;354: 911-23.

\section{References to studies excluded from this review}

\section{UK Antegren Study 1999 \{published data only\}}

* Tubridy N, Behan PO, Capildeo R, Chaudhuri A, Forbes $\mathrm{R}$, Hawkins CP, et al.The effect of anti-[alpha] 4 integrin antibody on brain lesion activity in MS. Neurology 1999;53 (3):466-72.

\section{References to studies awaiting assessment}

\section{INMSTG 2003 \{published data only\}}

Miller DH, Khan OA, Sheremata WA, Blumhardt LD, Rice GP, Libonati MA, et al.A controlled trial of nataluzimab for relapsing multiple sclerosis. NEJM 2003;348:15-23.

\section{Additional references}

\section{Balcer 2000}

Balcer LJ, Baier ML, Pelak VS, Fox RJ, Shuwairi S, Galetta SL, et al.New low-contrast vision charts: reliability and test characteristics in patients with multiple sclerosis. Multiple Sclerosis 2000;6:163-71.

\section{Belachew 2010}

Belachew S, Phan-Ba R, Bartholomé E, Delvaux V, Hansen I, Calay P, et al.Natalizumab induces a rapid improvement of disability status and ambulation after failure of previous therapy in relapsing-remitting multiple sclerosis. European Journal of Neurology 2010 Jun 16 [Epub ahead of print]. [DOI: $10.1111 /$ j.1468-1331.2010.03112.x]

Bergamaschi 2009

Bergamaschi R, Montomoli C. Melanoma in multiple sclerosis treated with natalizumab: causal association or coincidence?. Multiple Sclerosis 2009;15(12):1532.

\section{Berger 2009}

Berger E, Rumbach LP, Lavier A, Vermersch P, Outteryck $\mathrm{O}$, Ongagna JC, et al.Natalizumab use in two French Multiple Sclerosis Centers: the incidence of hypersensitivity reactions based on premedication practices. Neurology 2009;72(Suppl 3):A356.

Biogen Idec and Elan Pharmaceuticals 2006

Biogen Idec, Elan Pharmaceuticals. Tysabri ${ }^{\circledR}$ (natalizumab) Advisory Committee Briefing Document. www.fda.gov/ohrms/dockets/ac/06/briefing/2006-

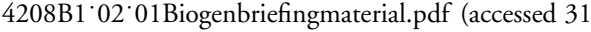
March 2010).

Biogen Idec Inc 2008

Biogen Idec Inc, Genentech USA Inc. Rituxan®. Full Prescribing Information - USA 09/2008.

Bozic 2007

Bozic C, Belcher G, Kooijmans M, Kim R, Lynn F, Panzara MA. The Safety of Natalizumab in Patients With Relapsing Multiple. Update from TOUCH ${ }^{T M}$ and TYGRIS. Poster No P06.095. Proceedings of the 59th Annual Meeting of the American Academy of Neurology; 2007 Apr 28 - May 5; Boston (MA). 2007.

Bozic 2009

Bozic C, LaGuette J, Panzara MA, Sandrock AW.

Natalizumab and central nervous system lymphoma: no clear association. Annals of Neurology 2009;66(3):261-2.

Bozic 2009a

Bozic C, Belcher G, Kim R, Hyde R, Lynn F, KooijmansCoutinho M, et al.Natalizumab in Patients with Relapsing Multiple Sclerosis: Updated Utilization and Safety Results including TOUCH and TYGRIS. Abstracts S11.005. American Academy of Neurology 61st Annual Meeting; 2009 Apr 25 - May 2; Seattle (WA). 2009.

\section{Calabresi 2007}

Calabresi PA, Giovannoni G, Confavreux C, Galetta SL, Havrdova E, Hutchinson M, et al.The incidence and significance of antinatalizumab antibodies: results from AFFIRM and SENTINEL. Neurology 2007;69:1391-403.

\section{Caon 2006}

Caon C, Din M, Ching W, Tselis A, Lisak R, Khan O. Clinical course after change of immunomodulating therapy in relapsing-remitting multiple sclerosis. European Journal of Neurology 2006;13:471-4.

Centonze 2008

Centonze D, Furlan R, Gasperini C, Salvetti M, Battistini L. Early relapses after the first dose of natalizumab in active multiple sclerosis patients. Multiple Sclerosis 2008;14: $1137-8$.

\section{Clifford 2010}

Clifford DB, DeLuca A, Simpson DM, Arendt G, Giovannoni G, Nath A. Natalizumab-associated progressive multifocal leukoencephalopathy in patients with multiple sclerosis: lessons from 28 cases. Lancet Neurology 2010;9 (4):438-46.

Cohen 2009

Cohen M, Rocher F, Brunschwig C, Lebrun C. Case report of recurrent pericarditis due to natalizumab treatment with positive re-challenging test. Neurology 2009;72(Supl 3): A357.

\section{Cohen 2010}

Cohen M, Rocher F, Vivinus S, Thomas P, Lebrun C. Giant urticaria and persistent neutralizing antibodies after the first natalizumab infusion. Neurology 2010;74:1394-5. [DOI: .1212/WNL.0b013e3181dad567]

Coyle 2009

Coyle PK Jeffery DR. Clinical efficacy and benefit of natalizumab. Multiple Sclerosis 2009;15(S4):S7-S15. [DOI: $10.1177 / 1352458509347129]$

\section{DerSimonian 1986}

DerSimonian R, Laird N. Meta-analysis in clinical trials. Controlled Clinical Trials 1986;7:177-88.

\section{Earnshaw 2009}

Earnshaw SR, Graham J, Oleen-Burkey M, Castelli-Haley J, Johnson K. Cost effectiveness of glatiramer acetate and natalizumab in relapsing-remitting multiple sclerosis . 
Applied Health Economics and Health Policy 2009;7(2): 91-108.

Ebers 2008

Ebers GC, Heigenhauser L, Daumer M, Lederer C, Noseworthy JH. Disability as an outcome in MS clinical trials. Neurology 2008;71:624-31. [DOI: 10.1212/ 01.wnl.0000313034.46883.16]

\section{FDA 2004}

Center for Drug Evaluation and Research. Reviewer: Bryan WW. Clinical Review BLA 125104/0 Tysabri (natalizumab). http://www.accessdata.fda.gov/drugsatfda docs/nda/2004/ 125104s000 Natalizumab'Medr'P1.pdf (accessed 31 December 2010).

\section{FDA 2004a}

Center for Drug Evaluation and Research. Office of Pharmacoepidemiology and Statistical Science. Office of Biostatistics. Statistical review and evaluation. Natalizumab. NDA/serial number $125104(0)$. http://www.fdable.com/ wiki/images/7/70/Statistical' review natalizumab.pdf (accessed 31 December 2010).

Filippi 2002

Filippi M. Predictive value of MRI findings in multiple sclerosis. The Lancet Neurology 2002;1:9.

\section{Francis 2008}

Francis G, Panzara M. Tysabri (Dear Healthcare Professional Letter). Biogen Idec and Elan Pharmaceuticals (accessed 01 May 2009).

\section{Freedman 2008}

Freedman MS, Hughes B, Mikol DD, Bennett R, Cuffel B, Divan V, et al.Efficacy of Disease-Modifying Therapies in Relapsing Remitting Multiple Sclerosis: A Systematic Comparison. European Neurology 2008;60:1-11.

\section{Freeman 2000}

Freeman JA, Thompson AJ. Community services in multiple sclerosis: still a matter of chance. Journal of Neurology Neurosurgery and Psychiatry 2000;69:728-32.

\section{Frohman 2006}

Frohman EM, Racke MK, Raine CS. Multiple sclerosis: the plaque and its pathogenesis. NEJM 2006;354(9):942-55.

\section{Gedizlioglu 2009}

Gedizlioglu M, Coban P, Ce P, Sivasli I. An unusual complication of immunosuppression in myasthenia gravis: Progressive multifocal leukoencephalopathy. Neuromuscular Disorders 2009;19(2):155-7.

\section{Ghalie 2002}

Ghalie RG, Edan G, Laurent M, Mauch E, Eisenman S, Hartung HP, et al.Cardiac Adverse Effects Associated with Mitoxantrone (Novantrone) Therapy in Patients with MS. Neurology 2002;59(6):909-13.

\section{Ghezzi 2010}

Ghezzi A, Pozzilli C, Grimaldi LM, Brescia Morra V, Bortolon F, Capra R, et al.Safety and efficacy of natalizumab in children with multiple sclerosis. Neurology 2010;75(10): 912-7.

\section{Giordano 2008}

Giordano A, Mattarozzi K, Pucci E, Leone M, Casini F, Collimedaglia L, et al.Participation in medical decisionmaking: Attitudes of Italians with multiple sclerosis. Journal of Neurological Sciences 2008;15(275(1-2)):86-91.

Giovannoni 2007

Giovannoni G, Kinkel RP, Vartanian T. Treating Multiple Sclerosis in the Natalizumab Era: Risks, Benefits, Clinical Decision Making, and a Comparison Between North American and European Union Practices. Reviews in Neurological Diseases 2007;4(4):184-93.

\section{Gold 2007}

Gold R, Jawad A, Miller DH, Henderson DC, Fassas A, Fierz W, et al.Expert opinion: guidelines for the use of natalizumab in multiple sclerosis patients previously treated with immunomodulating therapies. Journal of Neuroimmunology 2007;187:156-8.

\section{Goodin 2008}

Goodin DS, Cohen BA, O'Connor P, Kappos L, Stevens JC. Assessment: The use of natalizumab (Tysabri) for the treatment of multiple sclerosis (an evidence-based review): Report of the Therapeutics and Technology Assessment Subcommittee of the American Academy of Neurology. Neurology 2008;71:766-73. [: 10.1212/ 01.wnl.0000320512.21919.d2]

\section{Goodin 2008a}

Goodin DS. Disease-modifying therapy in multiple Sclerosis Update and clinical implications. Neurology 2008; 71(Suppl 3):S8-S13.

\section{Gronwall 1977}

Gronwall DMA. Paced Auditory Serial-Addition Task: a measure of recovery from concussion. Perceptual and Motor Skills 1977;44:367-73.

\section{Gutwinski 2010}

Gutwinski S, Erbe S, Munch C, Janke O, Muller U, Haas J. Severe cutaneous candida infection during natalizumab therapy in multiple sclerosis. Neurology 2010;74:521-3.

\section{Haartsen 2009}

Haartsen J, Marriott M, Butzkueven H. Early relapses after the first dose of natalizumab in active multiple sclerosis. Multiple Sclerosis 2009;15:520.

\section{Haupts 2008}

Haupts MR, Schimrigk SK, Brune N, Chan A, Ahle G, Hellwig K, et al.Fulminant tumefactive multiple sclerosis: Therapeutic implications of histopathology. Journal of Neurology 2008;255:1272-3. [DOI: 10.1007/ s00415-008-0883-x.]

\section{Hauser 2008}

Hauser SL, et al. for the HERMES Trial Group. BCell Depletion with Rituximab in Relapsing? Remitting Multiple Sclerosis. NEJM 2008;358:676-88.

\section{Heesen 2004}

Heesen C, Kasper J, Segal J, Kopke S, Mühlhauser I. Decisional role preferences, risk knowledge and information 
interests in patients with multiple sclerosis. Multiple Sclerosis 2004;10:643-50.

\section{Heesen 2010}

Heesen C, Kleiter I, Nguyen F, Schaffler N, Kasper J, Kopke S, et al.Risk perception in natalizumabtreated multiple sclerosis patients and their neurologists. Multiple Sclerosis 2010;16(12):1507-12. [DOI: 10.1177/ 1352458510379819]

\section{Hellwig 2008}

Hellwig K, Schimrigk S, Fischer M, Haghikia A, Müller T, Chan A, et al.Allergic and Nonallergic Delayed Infusion Reactions During Natalizumab Therapy. Archives of Neurology 2008;65(5):656-8.

\section{Higgins 2002}

Higgins JP, Thompson SG. Quantifying heterogeneity in a meta-analysis. Statistics in Medicine 2002;21:1539-58.

\section{Higgins 2003}

Higgins JP, Thompson SG, Deeks JJ, Altman DG. Measuring inconsistency in meta-analyses. BMJ 2003;327: 557-60.

\section{Higgins 2008}

Higgins JPT, Altman DG (editors). Chapter 8: Assessing risk of bias in included studies. In: Higgins JPT, Green S (editors). Cochrane Handbook for Systematic Reviews of Interventions Version 5.0.1 (updated September 2008). The Cochrane Collboration, 2008. Available from www.cochrane-handbook.org.

Horga 2010

Horga A, Castilló J, Río J, Tintoré M, Edo MC, PéerezMiralles F, et al.Effectiveness and safety of natalizumab in patients with relapsing multiple sclerosis: report of threeyear experience in a multiple sclerosis centre, Catalonia. P841. Proceedings of 26th Congress of the European Committee for Treatment and Research in Multiple Sclerosis (ECTRIMS) \& 15th Annual Conference of Rehabilitation in MS (RIMS); 2010 Oct 13-16; Gothenburg, Sweden. 2010.

\section{Hutchinson 2007}

Hutchinson M. Natalizumab: A new treatment for relapsing remitting multiple sclerosis. Therapeutics and Clinical Risk Management 2007;3(2):259-68.

\section{Hutchinson 2009}

Hutchinson M, Kappos L, Calabresi PA, Confavreux C, Giovannoni G, Galetta SL. The efficacy of natalizumab in patients with relapsing multiple sclerosis: subgroup analyses of AFFIRM and SENTINEL. Journal of Neurology 2009; 256:1035-37.

\section{ICH Expert Working Group 1994}

ICH Expert Working Group. In: Clinical Safety Data Management Definition and Standards for Expidet Reporting. International Conference on Harmonisation of Technical Requirements for Registration of Pharmaceuticals for Human Use (ICH); 1994 Oct 27. http:// www.private.ich.org/cache/compo/475-272-1.html\#E2A (accessed 31 December 2010).

\section{Ismail 2009}

Ismail A, Kemp J, Sharrack B. Melanoma complicating treatment with natalizumab (Tysabri) for multiple sclerosis. Journal of Neurology 2009;256(10): 1771.

\section{Jones 2008}

Jones D, Ionete C. Recurrent autoimmune

thrombocytopenia after exposure to interferon beta-1a and natalizumab. World Congress on Treatment and Research in Multiple Sclerosis, the first joint meeting of ACTRIMS (the Americas Committee on Treatment and Research in Multiple Sclerosis) and its counterparts in Europe and Latin America: ECTRIMS and LACTRIMS; 2008 Sept 17-20; Montréal. 2008.

\section{Kappos 2007}

Kappos L, Bates D, Hartung HP, Havrdova E, Miller D, Polman $\mathrm{CH}$, et al.Natalizumab treatment for multiple sclerosis: recommendations for patients selection and monitoring. Lancet Neurology 2007;6:431-41. [DOI: 10.1016/S1474-4422(07)70078-9]

\section{Kent 1995}

Kent SJ, Karlik SJ, Cannon C, Hines DK, Yednock TA, Fritz LC, et al.A monoclonal antibody to alpha 4 integrin suppresses and reverses active experimental allergic encephalomyelitis. Journal of Neuroimmunology 1995;58 (1):1-10. [PUBMED: 7730443]

\section{Killestein 2009}

Killestein J, Jasperse B, Liedorp M, Seewann A, Polman $\mathrm{CH}$. Very late delayed-allergic reaction to natalizumab not associated with neutralizing antibodies. Multiple Sclerosis 2009;15(4):525-6. [PUBMED: 19324985 ]

Killestein 2010

Killestein J, Vennegoor A, Strijbis EM, Seewann A, van Oosten BW, Uitdehaag BM, et al.Natalizumab drug holiday in multiple sclerosis: Poorly tolerated. Annals of Neurology 2010;68:392-5.

\section{Klawiter 2009}

Klawiter EC, Cross AH, Naismith RT. The present efficacy of multiple sclerosis therapeutics. Is the new $66 \%$ just the old 33\%?. Neurology 2009;73:984-90.

\section{Kleinschmidt-DeMasters 2005}

Kleinschmidt-DeMasters BK, Tyler KL. Progressive multifocal leukoencephalopathy complicating treatment with natalizumab and interferon beta-1a for multiple sclerosis. NEJM 2005;353:369-74.

\section{Koralnik 2004}

Koralnik IJ. New insights into progressive multifocal leukoencephalopathy. Current Opinion in Neurology 2004; 17:365-70.

Kos 2005

Kos D, Kerckhofs E, Carrea I, Verza R, Ramos M, Jansa J. Evaluation of the Modified Fatigue Impact Scale in four different European countries. Multiple Sclerosis 2005;11(1): 76-80.

\section{Krumbholz 2007}

Krumbholz M, Pellkofer H, Gold R, Hoffmann LA, Hohlfeld R, Kümpfel T. Delayed allergic reaction to 
natalizumab associated with early formation of neutralizing antibodies. Archives of Neurology 2007;64(9):1331-3.

\section{Kurtzke 1983}

Kurtzke JF. Rating neurologic impairment in multiple sclerosis: an expanded disability status scale (EDSS). Neurology 1983;33(11):1444-52. [PUBMED: 6685237]

\section{Langer-Gould 2005}

Langer-Gould A, Atlas SW, Green AJ, Bollen AW, Pelletier D. Progressive multifocal leukoencephalopathy in a patient treated with natalizumab. NEJM 2005;353:375-81.

\section{Laroni 2010}

Laroni A, Bedognetti M, Uccelli A, Capello E, Mancardi GL. Association of melanoma and natalizumab therapy in the Italian MS population: a second case report. Neurological Sciences 2010 Nov 5 [Epub ahead of print].

Leav 2003

Leav BA, Mackay M, Ward HD. Cryptosporidium species: new insights and old challenges. Clinical Infectious Diseases 2003;36:903-8.

Lee 2009

Lee MB, Amezcua L. Natalizumab for stabilization of Susac syndrome. Neurology 2009;72(Suppl 3):A203.

\section{Lublin 1996}

Lublin FD, Reingold SC. Defining the clinical course of multiple sclerosis:Results of an international survey. Neurology 1996;46:907-11.

\section{Lucchinetti 1996}

Lucchinetti CF, Brück W, Rodriguez M, Lassmann H. Distinct patterns of multiple sclerosis pathology indicates heterogeneity in pathogenesis. Brain Pathology 1996;6: $259-74$.

Maggs 2004

Maggs FG, Palace J. The pathogenesis of multiple sclerosis: is it really a primary inflammatory process?. Multiple Sclerosis 2004;10(3):326-9.

Mancardi 2010

Mancardi GL, Tedeschi G, Amato MP, D’Alessandro R, Drago F, Milanese C, et al.Three years of experience: the Italian registry and safety data update. Neurological Sciences 2010 July 20 [Epub ahead of print]. [PUBMED: 20644975]

\section{Martino 2002}

Martino G, Adorini L, Rieckmann P, Hillert J, Kallmann B, Comi G, et al.Inflammation in multiple sclerosis: the good, the bad, and the complex. Lancet Neurology 2002;1:499509.

\section{McDonald 2001}

McDonald WI, Compston A, Edan G, Goodkin D, Hartung HP, Lublin FD, et al.Recommended diagnostic criteria for multiple sclerosis: guidelines from the International Panel on the diagnosis of multiple sclerosis. Annals of Neurology 2001;50(1):121-7. [PUBMED: 11456302]

\section{Miravalle 2011}

Miravalle A, Jensen R, Kinkel P. Immune reconstitution inflammatory syndrome in patients with multiple sclerosis following cessation of Natalizumab therapy. Archives of Neurology 2011;68(2):186-91. [DOI: 10.1001/ archneurol.2010.257]

\section{Moher 1998}

Moher D, Pham B, Jones A, Cook DJ, Jadad AR, Moher $\mathrm{M}$, et al.Does quality of reports of randomised trials affect estimates of intervention efficacy reported in meta-analyses? . Lancet 1998;352:609-13. [PUBMED: 0009746022]

\section{Moher 2001}

Moher D, Schulz KF, Altman DG. The CONSORT

Statement: Revised Recommendations for Improving the Quality of Reports of Parallel-Group Randomized Trials. Annals of Internal Medicine 2001;134:657-62.

\section{Moore 2008}

Moore RA, Derry S, McQuay HJ, Paling J. What do we know about communicating risk? A brief review and suggestion for contextualising serious, but rare, risk, and the example of cox-2 selective and non-selective NSAIDs. Arthritis Research \& Therapy 2008;10(1):R20.

\section{Mori 1992}

Mori M, Aoki N, Shimada H, Tajima M, Kato K. Detection of JC virus in the brains of aged patients without progressive multifocal leukoencephalopathy by the polymerase chain reaction and Southern hybridization analysis. Neuroscience Letters 1992;141:151-5.

Mullen 2008

Mullen JT, Vartanian TK, Atkins MB. Melanoma

Complicating Treatment with Natalizumab for Multiple Sclerosis. NEJM 2008;358:647-8.

Niino 2006

Niino M, Bodner C, Simard ML, Alatab S, Gano D, Kim $\mathrm{HJ}$, et al.Natalizumab effects on immune cell responses in multiple sclerosis. Annals of Neurology 2006;59(5):748-54. [PUBMED: 16634035]

\section{Norman 2003}

Norman GR, Sloan JA, Wyrwich KW. Interpretation of changes in health-related quality of life. The remarkable universality of half a standard deviation. Medical Care 2003; 41:582-92.

\section{O’Connor 2010}

O'Connor PW, Goodman AD, Kappos L, Lublin FD, Polman $\mathrm{CH}$, Rudick RA, et al.Updated efficacy and safety of natalizumab in patients who participated in the STRATA study. Proceedings of 26th Congress of the European Committee for Treatment and Research in Multiple Sclerosis (ECTRIMS) \& 15th Annual Conference of Rehabilitation in MS (RIMS); 2010 Oct 13-16; Gothenburg, Sweden. 2010.

O'Connor 2004

O'Connor PW, Goodman AD, Willmer-Hulme AJ, Libonati MA, Metz L, Murray RS, et al.Randomized multicenter trial of natalizumab in acute MS relapses. Clinical and MRI effects. Neurology 2004;62:2038-43.

\section{Oturai 2009}

Oturai AB, Koch-Henriksen N, Petersen T, Jensen PEH, Sellebjerg F, Sorensen PS. Efficacy of natalizumab in 
multiple sclerosis patients with high disease activity: a Danish nationwide study. European Journal of Neurology 2009; 16:420-3.

\section{Outteryck 2009}

Outteryck O, Lacour A, Zephir H, Ferriby D, Vermersch P. Autoimmune haemolytic anemia under treatment with natalizumab. Neurology 2009;72(Suppl 3):A317.

\section{Outteryck 2010}

Outteryck O, Ongagna JC, Zéphir H, Fleury MC, Lacour A, Blanc F, et al.Demographic and clinic characteristics of French patients treated with natalizumab in clinical practice. Journal of Neurology 2010;257(2):207-11.

\section{Pagnoux 2003}

Pagnoux C, Hayem G, Roux F, Rouidi SA, Palazzo E, Hénin D, et al.JC virus leukoencephalopathy complicating Wegener's granulomatosis. Joint Bone Spine 2003;70(5): 376-9.

Panitch 2002 Panitch H, Goodin DS, Francis G, Chang P, Coyle PK, O'Connor P, et al.Randomized, comparative study of interferon $\beta$-1a treatment regimens in MS. The EVIDENCE Trial. Neurology 2001;59:1496-506.

\section{Piehl 2010}

Piehl F, Holmén C, Hillert J, Olsson T. Swedish natalizumab (Tysabri) multiple sclerosis surveillance study. Neurolocial Sciences 2010 Jun 16 [Epub ahead of print].

\section{Pittock 2007}

Pittock SJ. Implications for treatment. Does benign multiple sclerosis today imply benign multiple sclerosis tomorrow?. Neurology 2007;68:480-1. [DOI: 10.1212/ 01.wnl.0000255797.19050.e8]

Polman 2005

Polman CH, Reingold SC, Edan G, Filippi M, Hartung HP, Kappos L, et al.Diagnostic criteria for multiple sclerosis: 2005 revisions to the 'McDonald' criteria. Annals of Neurology 2005;58:840-6. [PUBMED: 12941579]

\section{Poser 1983}

Poser CM, Paty DW, Scheinberg L, McDonald WI, Davis FA, Ebers GC, et al.New diagnostic criteria for multiple sclerosis: guidelines for research protocols. Annals of neurology 1983;13(3):227-31. [PUBMED: 6847134]

\section{Putzki 2009}

Putzki N, Yaldizli O, Tettenborn B, Diener HC. Multiple sclerosis associated fatigue during natalizumab treatment. Journal of the Neurological Sciences 2009;285(1-2):109-13.

\section{Putzki 2010}

Putzki N, Yaldizli O, Bühler R, Schwegler G, Curtius D, Tettenborn B. Natalizumab reduces clinical and MRI activity in multiple sclerosis patients with high disease activity: results from a multicenter study in Switzerland. European Neurology 2010;63(2):101-6.

\section{Putzki 2010a}

Putzki N, Yaldizli O, Mäurer M, Cursiefen S, Kuckert $\mathrm{S}$, Klawe C, et al.Efficacy of natalizumab in second line therapy of relapsing-remitting multiple sclerosis: results from a multi-center study in German speaking countries. European Journal of Neurology 2010;17(1):31-7.

Raji 2009

Raji A, Winkler G. Natalizumab in the therapy of multifocal motoric neuropathy (MMN): first case report. Neurology 2009;72(Suppl 3):A134.

\section{Ransohoff 2007}

Ransohoff RM. Natalizumab for Multiple Sclerosis. NEJM 2007;356:2622-9.

\section{Review Manager (RevMan) 2008}

The Nordic Cochrane Centre, The Cochrane Collaboration. Review Manager (RevMan). 5.0. Copenhagen: The Nordic Cochrane Centre, The Cochrane Collaboration, 2008.

\section{Rinaldi 2009}

Rinaldi F, Perini P, Calabrese M, Rinaldi L, Gallo P. Severe relapses after the first infusion of natalizumab in active relapsing-remitting multiple sclerosis. Multiple Sclerosis 2009;15(11):1359-62.

Rosser 2003

Rosser DA, Cousens SN, Murdoch IE, Fitzke FW, Laidlaw DA. How sensitive to clinical change are ETDRS and $\log$ MAR visual acuity measurements?. Investigative Ophthalmology and Visual Science 2003;44:3278-81.

\section{Rudick 2002}

Rudick RA, Cutter G, Reingold S. The Multiple Sclerosis Functional Composite: a new clinical outcome measure for multiple sclerosis trials. Multiple Sclerosis 2002;8:359.

Rudick 2004

Rudick RA, Sandrock A. Natalizumab: a4-integrin antagonist selective adhesion molecule inhibitors for MS. Expert Review Neurotherapeutics 2004;4:571-80.

Sangalli 2010

Sangalli F, Moiola L, Annovazzi P, Bucello S, Radaelli M, Ghezzi A, et al.Three years efficacy and tolerability of natalizumab treatment. P896. Proceedings of 26th Congress of the European Committee for Treatment and Research in Multiple Sclerosis (ECTRIMS) \& 15th Annual Conference of Rehabilitation in MS (RIMS); 2010 Oct 1316; Gothenburg, Sweden. 2010.

\section{Schneider 1991}

Schneider F. Progressive multifocal leukoencephalopathy as a cause of neurologic symptoms in Sharp syndrome. Zeitschrift fur Rheumatologie 1991;50(4):222-4.

\section{Schulz 1995}

Schulz KF, Chalmers I, Hayes RJ, Altman DG. Empirical Evidence of BiasDimensions of Methodological Quality Associated With Estimates of treatment Effects in Controlled trials. JAMA 1995;273:408-12. [PUBMED: 0007823387]

\section{Schweikert 2009}

Schweikert A, Kremer M, Ringel F, Liebig T, Duyster J, Stüve $\mathrm{O}$, et al.Primary central nervous system lymphoma in a patient treated with natalizumab. Annals of Neurology 2009;66:403-6. 


\section{Schwid 2005}

Schwid SR, Thorpe J, Sharief M, Sandberg-Wollheim M, Rammohan K, Wendt J, et al.Enhanced Benefit of Increasing Interferon Beta-1a Dose and Frequency in Relapsing Multiple Sclerosis. The EVIDENCE Study. Archives of Neurology 2005;62:785-92.

\section{Sharief 2003}

Sharief MK. The impact of change in interferon beta-1a dose regimen (30 mcg qw to $44 \mathrm{mcg}$ tiw) in patients with relapsing MS - cross-over results from the EVIDENCE study. ENS Meeting; 2003 June; Istanbul, Turkey. 2003.

\section{Sheremata 1999}

Sheremata WA, Vollmer TL, Stone LA, Willmer-Hulme AJ, Koller M. A safety and pharmacokinetic study of intravenous natalizumab in patients with MS. Neurology 1999;52:1072-4.

\section{Solari 2007}

Solari A, Acquarone N, Pucci E, Martinelli V, Marrosu MG Trojano M, et al.Communicating the diagnosis of multiple sclerosis - a qualitative study. Multiple Sclerosis 2007;13(6): 763-9.

Stephenson 2009

Stephenson JJ, Kamat SA, Rajagopalan K, Agarwal SS, Singer J. Early effects of natalizumab on patient reported fatigue and cognitive function. Neurology 2009;72(Suppl 3):A84.

\section{Straffi 2010}

Straffi L, Martinelli V, Amato M, Bellantonio P, Bergamaschi $\mathrm{R}$, Bertolotto A, et al.Incidence rate of acute myeloid leukaemia and related mortality in Italian Multiple Sclerosis patients treated with mitoxantrone. Neurological Sciences 2010;31(Suppl):S2-S3.

Tan 2010

Tan CS, Koralnik IJ. Progressive multifocal leukoencephalopathy and other disorders caused by JC virus: clinical features and pathogenesis. Lancet Neurology 2010;9:425-37.

Targan 2007

Targan SR, Feagan BG, Fedorak RN, Lashner BA, Panaccione R, Present DH, et al.Natalizumab for the treatment of active Crohn's disease: results of the ENCORE Trial. Gastroenterology 2007;132:1672-83.

Thompson 2008

Thompson JP, Noyes K, Dorsey ER, Schwid SR, Holloway RG. Quantitative risk-benefit analysis of natalizumab. Neurology 2008;71:357-64. [DOI: 10.1212/ 01.wnl.0000319648.65173.7a]

Trapp 1998

Trapp BD, Peterson J, Ransohoff RM, Rudick R, Mörk S, Bö L. Axonal transection in the lesions of multiple sclerosis. NEJM 1998;338:278-85.

Tremlett 2006

Tremlett H, Paty D, Devonshire V. Disability progression in multiple sclerosis is slower than previously reported. Neurology 2006;66:172-7.

\section{Tremlett 2010}

Tremlett H, Zhao Y, Rieckmann P, Hutchinson M. New perspectives in the natural history of multiple sclerosis. Neurology 2010;74:2004-15.

\section{US FDA 2008}

US Food, Drug Administration. Natalizumab (marketed as TYSABRI): Serious liver injury. http://www.fda.gov/cder/ dsn/2008 spring/postmarketing.htm\#natalizumab 2008 (accessed 1 March 2010)

\section{US FDA 2009}

US Food, Drug Administration. Information on Natalizumab (marketed as Tysabri). http://www.fda.gov/Drugs/DrugSafety/ PostmarketDrugSafetyInformationforPatientsandProviders/ ucm107198.htm 9/2009 (accessed 31 December 2010).

\section{US FDA 2010}

US Food, Drug Administration. Risk of Progressive Multifocal Leukoencephalopathy (PML) with the use of Tysabri (natalizumab). FDA Drug Safety Communication http://www.fda.gov/Drugs/DrugSafety/ PostmarketDrugSafetyInformationforPatientsandProviders, 05.02.2010 (accessed 1 March 2010).

Van Assche 2005

Van Assche G, Van Ranst M, Sciot R, Dubois B, Vermeire S, Noman M, et al.Progressive multifocal leukoencephalopathy after natalizumab therapy for Crohns disease. NEJM 2005; 353:362-8.

\section{Vickrey 2000}

Vickrey BG, Shatin D, Wolf SM, Myers LW, Belin TR, Hanson RA, et al.Management of multiple sclerosis across managed care and fee-for-service systems. Neurology 2000; 55:1341-9.

Vollmer 2004

Vollmer TL, Phillips JT, Goodman AD, Agius MA, Libonat MA, Giacchino JL, et al.An open-label safety and drug interaction study of natalizumab (Antegren) incombination with interferon-beta (Avonex) in patients with multiple sclerosis. Multiple Sclerosis 2004;10(5):511-20.

Ware 1992

Ware JE, Sherbourne CD. The MOS SF-36 Short-Form Health Survey (SF-36). Conceptual framework and item selection. Medical Care 1992;30:473-81.

Ware 1993

Ware JE. SF-36 Health Survey: Manual and interpretation guide. Boston MA: The Health Institute, New England Medical Centre, 1993.

Warnke 2010

Warnke C, Menge T, Hartung HP, Racke MK, Cravens PD, Bennett JL, et al.Natalizumab and progressive multifocal leukoencephalopathy: what are the causal factors and can it be avoided?. Archives of Neurology 2010;67(8):923-30.

Weinshenker 1989

Weinshenker BG, Bass B, Rice GP, Noseworthy J, Carriere W, Baskerville J, et al.Natural history of multiple sclerosis: a 
geographically based study. 1 . Clinical course and disability. Brain 1989;112:133-46.

\section{Wenning 2009}

Wenning W, Haghikia A, Laubenberger J, Clifford DB, Behrens PF, Chan A, et al.Treatment of Progressive Multifocal Leukoencephalopathy Associated with Natalizumab. NEJM 2009;361:1075-80.

West 2010

West TW, Cree BAC. Natalizumab dosage suspension: Are we helping or hurting?. Annals of Neurology 2010;68:395-9.

\section{White 1992}

White FA 3rd, Ishaq M, Stoner GL, Frisque RJ. JC virus DNA is present in many human brain samples from patients without progressive multifocal leukoencephalopathy. Journal of Virology 1992;66:5726-34.

White 2002

White RP, Abraham S, Singhal S, Manji H, Clarke CRA . Progressive multifocal leukencephalopathy isolated to the posterior fossa in a patient with systemic lupus erythematosus. Rheumatology 2002;41:826-7.

Yaldizli 2009

Yaldizli O, Putzki N. Natalizumab in the treatment of multiple sclerosis. Therapeutic Advances in Neurological Disorders 2009;2:115-28. [DOI: 10.1177/ $1756285608101861]$

\section{Yednock 1992}

Yednock TA, Cannon C, Fritz LC, Sanchez-Madrid F, Steinman L, Karin N. Prevention of experimental autoimmune encephalomyelitis by antibodies against alpha 4 beta 1 integrin. Nature 1992;356(6364):63-6. [PUBMED: 1538783]

\section{Yousry 2006}

Yousry TA, Major EO, Ryschkewitsch C, Fahle G, Fischer S, Hou J, et al.Evaluation of patients treated with natalizumab for progressive multifocal leukoencephalopathy. NEJM 2006;354(9):924-33. [PUBMED: 16510746]

\section{Zecca 2009}

Zecca C, Nessi F, Bernasconi E, Gobbi C. Ocular toxoplasmosis during natalizumab treatment. Neurology 2009;73(17):1418-9. [DOI: 10.1212/ WNL.0b013e3181bd114f]

\section{Zephir 2009}

Zephir H, Carpentier O, Outteryck O, Lacour A, Ferriby D, Vermersch P. Extensive erosive dermatitis associated with hypereosinophilia under natalizumab treatment. Neurology 2009;72(Suppl 3):A241.

\section{Zwibel 2006}

Zwibel HL. Glatiramer acetate in treatment-naïve and prior interferon- $ß$ - $1 \mathrm{~b}$-treated multiple sclerosis patients. Acta neurologica Scandinavica 2006;113:378-86.

* Indicates the major publication for the study 


\section{CHARACTERISTICS OF STUDIES}

\section{Characteristics of included studies [ordered by study ID]}

\section{AFFIRM 2006}

Methods

Participants

Interventions

Outcomes
Phase 3, multicentre, randomised, double-blind, placebo controlled trial

99 centers in Europe, North America, Australia, and New Zealand enrolled 942 patients recruited from November 6, 2001 to January 31, 2005. Inclusion criteria: age $=18-50$ years, diagnosis of RRMS (McDonald criteria), EDSS=0-5.0; at least one medically documented relapse within the 12 months before the study began

Exclusion criteria: a relapse within 50 days before the administration of the first dose of the study drug; treatment with cyclophosphamide or mitoxantrone within the previous year, or treatment with IFNß, GA, cyclosporine, azathioprine, methotrexate, or intravenous immune globulin within the previous 6 months; treatment with IFNß, GA, or both for more than six months

Patients were randomly assigned in a 2:1 ratio to receive either NTZ (at a dose of 300 $\mathrm{mg}$ ) or placebo by intravenous infusion every 4 weeks for up to 116 weeks

Primary endpoints: rate of clinical relapse at 1 year; rate of sustained progression of disability at 2 years, as measured by EDSS, defined as an increase of 1.0 or more on the EDSS from a baseline score of 1.0 or more or an increase of 1.5 or more from a baseline score of 0 , that was sustained for 12 weeks (progression could not be confirmed during a relapse). Secondary endpoints: different MRI parameters at 1 and 2 years; the proportion of relapse free patients at 1 year; rate of clinical relapse at 2 years; progression of disability at 2 years, as measured by MSFC. Tertiary endpoints: Visual function testing (Sloan charts) ; Physical Component Summary (PCS) and Mental Component Summary (MCS) from SF-36; Subject Global Assessment Visual Analog Scale

3 patients who were assigned to receive placebo were never treated; these patients were included in the intention-to-treat efficacy analyses but were excluded from the safety analyses

Binding antibodies against NTZ were assessed.

\section{Risk of bias}

\begin{tabular}{|c|c|c|}
\hline Bias & Authors' judgement & Support for judgement \\
\hline $\begin{array}{l}\text { Random sequence generation (selection } \\
\text { bias) }\end{array}$ & Low risk & $\begin{array}{l}\text { quote "Patients were randomly assigned in } \\
\text { a 2:1 ratio to treatment that was stratified } \\
\text { according to study site in blocks of three } \\
\text { (two active, one placebo) with the use of } \\
\text { a computer-generated block randomisation } \\
\text { schedule" }\end{array}$ \\
\hline Allocation concealment (selection bias) & Low risk & $\begin{array}{l}\text { quote: "a multi digit identification num- } \\
\text { ber, implemented by an interactive voice- } \\
\text { response system was used" }\end{array}$ \\
\hline
\end{tabular}




\begin{tabular}{|c|c|c|}
\hline $\begin{array}{l}\text { Blinding (performance bias and detection } \\
\text { bias) } \\
\text { objective outcomes }\end{array}$ & Low risk & $\begin{array}{l}\text { quote: "All study personnel, patients, spon- } \\
\text { sor personnel involved in the conduct of the } \\
\text { study, and the investigator advisory com- } \\
\text { mittee were unaware of treatment assign- } \\
\text { ments throughout the study" }\end{array}$ \\
\hline $\begin{array}{l}\text { Blinding (performance bias and detection } \\
\text { bias) } \\
\text { subjective outcomes }\end{array}$ & Low risk & $\begin{array}{l}\text { quote: "All study personnel, patients, spon- } \\
\text { sor personnel involved in the conduct of the } \\
\text { study, and the investigator advisory com- } \\
\text { mittee were unaware of treatment assign- } \\
\text { ments throughout the study" }\end{array}$ \\
\hline $\begin{array}{l}\text { Incomplete outcome data (attrition bias) } \\
\text { All outcomes }\end{array}$ & Unclear risk & $\begin{array}{l}\text { quote: " } 8 \text { percent of patients in the } \\
\text { NTZ group and } 10 \text { percent of those in } \\
\text { the placebo group) withdrew from the } \\
\text { study. Thirty-nine patients discontinued } \\
\text { the study drug but completed follow-up (a } \\
\text { total of } 4 \text { percent, including } 4 \text { percent of } \\
\text { patients in the NTZ group and } 5 \text { percent of } \\
\text { those in the placebo group)". "All analyses } \\
\text { followed the intention-to-treat principle." } \\
\text { A CONSORT flowchart is shown. } \\
\text { However, the AFFIRM Authors did not re- } \\
\text { port how the outcomes for patient with- } \\
\text { drawals were assigned in the ITT analysis }\end{array}$ \\
\hline Selective reporting (reporting bias) & Low risk & No selective reporting was identified. \\
\hline Independent Funding Source & High risk & $\begin{array}{l}\text { Supported by Biogen Idec and Elan Phar- } \\
\text { maceuticals. Data were } \\
\text { analysed by Biogen Idec and Elan Pharma- } \\
\text { ceuticals. }\end{array}$ \\
\hline
\end{tabular}

GLANCE 2009

Methods

Participants
Phase 2, multicentre, randomised, double-blind, add-on, placebo-controlled, parallelgroup study

110 patients from 25 centres in US and Canada (between June 17, 2003 and March 23, 2004. Eligible patients: aged 18-55 years, diagnosis of RRMS (McDonald criteria), EDSS $=0-5.0$, treatment with GA for at least 12 months before randomisation, one or more relapses during that time. Exclusion criteria: diagnosis of progressive MS, MS relapse within 50 days before randomisation, clinically significant infectious illness within 30 days of randomisation, abnormal laboratory results (or history thereof) indicative of any major organ system disease precluding administration of NTZ or GA, history of severe allergic or anaphylactic reactions, known drug hypersensitivity, or history of malignancy (excluding nonmetastatic basal cell carcinoma). Women who were pregnant, at risk of or planning to become pregnant, or breast-feeding were excluded 
GLANCE 2009 (Continued)

\begin{tabular}{|c|c|c|}
\hline Interventions & \multicolumn{2}{|c|}{$\begin{array}{l}\text { IV NTZ } 300 \mathrm{mg} \text { or placebo once every } 4 \text { weeks plus GA } 20 \mathrm{mg} \text { subcutaneously once } \\
\text { daily for } 24 \text { weeks }\end{array}$} \\
\hline Outcomes & \multicolumn{2}{|c|}{$\begin{array}{l}\text { Primary endpoint: rate of development of new active lesions on cranial MRI. Secondary } \\
\text { endpoints: AEs }\end{array}$} \\
\hline Notes & \multicolumn{2}{|c|}{$\begin{array}{l}\text { Aims: safety and tolerability data. The main hypothesis was that, because the proposec } \\
\text { mechanism of action of GA requires cellular entry into the brain, NTZ might impai } \\
\text { rather than enhance the efficacy of GA } \\
\text { Binding antibodies against NTZ were assessed. }\end{array}$} \\
\hline \multicolumn{3}{|l|}{ Risk of bias } \\
\hline Bias & Authors' judgement & Support for judgement \\
\hline $\begin{array}{l}\text { Random sequence generation (selection } \\
\text { bias) }\end{array}$ & Unclear risk & $\begin{array}{l}\text { quote:"Patients were randomly assigned } 1 \text { : } \\
1 \text { to receive IV NTZ } 300 \text { mg or placebo" } \\
\text { However, the investigators did not describe } \\
\text { a random component in the sequence gen- } \\
\text { eration process }\end{array}$ \\
\hline Allocation concealment (selection bias) & Unclear risk & unclear \\
\hline $\begin{array}{l}\text { Blinding (performance bias and detection } \\
\text { bias) } \\
\text { objective outcomes }\end{array}$ & Low risk & $\begin{array}{l}\text { quote: "All study personnel, patients, and } \\
\text { sponsor personnel involved in study con- } \\
\text { duct were blinded to treatment assign- } \\
\text { ments" }\end{array}$ \\
\hline $\begin{array}{l}\text { Blinding (performance bias and detection } \\
\text { bias) } \\
\text { subjective outcomes }\end{array}$ & Low risk & $\begin{array}{l}\text { quote: "All study personnel, patients, and } \\
\text { sponsor personnel involved in study con- } \\
\text { duct were blinded to treatment assign- } \\
\text { ments" }\end{array}$ \\
\hline $\begin{array}{l}\text { Incomplete outcome data (attrition bias) } \\
\text { All outcomes }\end{array}$ & Unclear risk & $\begin{array}{l}\text { A CONSORT flowchart is shown. } \\
\text { However, the GLANCE Authors did not } \\
\text { report how the outcomes for patient with- } \\
\text { drawals were assigned in the ITT analysis }\end{array}$ \\
\hline Selective reporting (reporting bias) & Low risk & No selective reporting was identified. \\
\hline Independent Funding Source & High risk & $\begin{array}{l}\text { This study was supported by Biogen Idec, } \\
\text { Inc. and Elan Pharmaceuticals, Inc }\end{array}$ \\
\hline
\end{tabular}


Methods

Participants
Phase 3, multicentre, randomised, double-blind, add-on, placebo controlled trial

124 centers in Europe and US enrolled 1196 patients beginning on January 14, 2002 up to February 28, 2005 (planned May 31, 2005). Inclusion criteria: age $=18-55$ years; diagnosis of RRMS (McDonald criteria), EDSS=0-5.0; at least one relapse within the 12 months before randomisation; treatment with IFNß-1a im for at least 12 months before randomisation. Exclusion criteria: a relapse within 50 days before randomisation; treatment with an approved disease-modifying therapy other than IFNß-1a im once weekly within the 12-month period before randomisation

Interventions

Patients were randomly assigned, in a 1:1 ratio, to receive $300 \mathrm{mg}$ of NTZ (589 patients) or placebo (582 patients) intravenously every 4 weeks in addition to IFNß-1a (Avonex, Biogen Idec) at a dose of $30 \mu \mathrm{g}$ intramuscularly once weekly for up to 116 weeks

Outcomes

Primary endpoints: rate of clinical relapse at 1 year; rate of sustained progression of disability at 2 years, as measured by EDSS, defined as an increase of 1.0 or more on the EDSS from a baseline score of 1.0 or more or an increase of 1.5 or more from a baseline score of 0 , that was sustained for 12 weeks (progression could not be confirmed during a relapse)

Secondary endpoints: different MRI parameters at 1 and 2 years; the proportion of relapse free patients at 1 year; rate of clinical relapse at 2 years; progression of disability at 2 years, as measured by MSFC

Tertiary endpoints: Visual function testing (Sloan charts) ; Physical Component Summary (PCS) and Mental Component Summary (MCS) from SF-36

Notes

One center with 25 patients was excluded before unblinding owing to irregularities in data. Thus, the number of patients included in data analysis was 1171

Following the recognition of two cases of PML in patients who had been receiving NTZ in combination with IFNß-1a (Avonex®) for over 2 years, Biogen Idec and Elan Pharmaceuticals, in discussions with FDA, suspended commercialisation and clinical trials on 28 February 2005

Binding antibodies against NTZ were assessed.

\section{Risk of bias}

\begin{tabular}{l|l|l}
\hline Bias & Authors' judgement & Support for judgement \\
\hline $\begin{array}{l}\text { Random sequence generation (selection } \\
\text { bias) }\end{array}$ & Low risk & $\begin{array}{l}\text { quote: "Randomization was stratified ac- } \\
\text { cording to study site in blocks of four (two } \\
\text { active and two placebo) with the use of a } \\
\text { computer-generated schedule" }\end{array}$ \\
\hline $\begin{array}{l}\text { Allocation concealment (selection bias) } \\
\text { cow risk }\end{array}$ & Lom & $\begin{array}{l}\text { quote: "a multidigit identification num- } \\
\text { ber, implemented by an interactive voice- } \\
\text { response system was used" }\end{array}$ \\
\hline $\begin{array}{l}\text { Blinding (performance bias and detection } \\
\text { bias) } \\
\text { objective outcomes }\end{array}$ & Low risk & $\begin{array}{l}\text { quote: "All study personnel, patients, spon- } \\
\text { sor personnel involved in the conduct of the } \\
\text { study, and members of the investigator ad- }\end{array}$ \\
\hline
\end{tabular}

Natalizumab for relapsing remitting multiple sclerosis (Review)

Copyright ( 201 I The Cochrane Collaboration. Published by John Wiley \& Sons, Ltd. 
SENTINEL 2006 (Continued)

visory committee were blinded to the treatment assignments throughout the study"

Blinding (performance bias and detection Low risk

bias)

subjective outcomes

quote: "All study personnel, patients, sponsor personnel involved in the conduct of the study, and members of the investigator advisory committee were blinded to the treatment assignments throughout the study"

Incomplete outcome data (attrition bias) Unclear risk

All outcomes

quote: "12 percent of the group assigned to IFNß-1a plus NTZ and 16 percent of the group assigned to IFNß-1a alone) withdrew from the study". " 5 percent of the combination-therapy group and 6 percent of the group assigned to IFNß-1a alone discontinued the study drug but completed follow-up ". "All analyses followed the intention-to-treat principle."

A CONSORT flowchart is shown.

However, the SENTINEL authors did not report how the outcomes for patient withdrawals were assigned in the ITT analysis

\begin{tabular}{lll} 
Selective reporting (reporting bias) & Low risk & No selective reporting was identified. \\
\hline Independent Funding Source & High risk & $\begin{array}{l}\text { Supported by Biogen Idec and Elan Phar- } \\
\text { maceuticals. }\end{array}$
\end{tabular}

\section{Characteristics of excluded studies [ordered by study ID]}

Study Reason for exclusion

UK Antegren Study 1999 Dosage: $3 \mathrm{mg} / \mathrm{kg}$.

\section{Characteristics of studies awaiting assessment [ordered by study ID]}

\section{INMSTG 2003}

\begin{tabular}{ll} 
Methods & Randomized, double-blind trial, placebo-controlled. \\
\hline Participants & 213 patients with RRMS or relapsing SPMS.
\end{tabular}

Interventions Three arms: (i) $3 \mathrm{mg}$ of intravenous $\mathrm{NTZ}$ per kilogram of body weight (N=68), (ii) $6 \mathrm{mg}$ per kilogram ( $\mathrm{N}=74$ ), (iii) placebo $(\mathrm{N}=71)$ every 28 days for 6 months 
INMSTG 2003

Outcomes The primary end point was the number of new brain lesions on monthly gadolinium-enhanced MRI during the sixmonth treatment period. Other MRI outcomes included the number of persistent enhancing lesions; the volume of enhancing lesions; the number of new active lesions (the number of new enhancing lesions plus the number of new or newly enlarging, nonenhancing lesions on T2-weighted MRI); and the number of scans showing one or more new enhancing lesions. Secondary and tertiary clinical end points included the frequency of relapse, EDSS changes, and patients' own assessments of well-being

Notes Since the trial duration was 6 months, this study was included with the sole aim of assessing tolerability/safety data. Data on RRMS only in the $6 \mathrm{mg}$ per

kilogram arm are pending. 
DATA AND ANALYSES

Comparison 1. Primary Efficacy Outcome (Natalizumab vs Control)

\begin{tabular}{|c|c|c|c|c|}
\hline Outcome or subgroup title & $\begin{array}{l}\text { No. of } \\
\text { studies }\end{array}$ & $\begin{array}{c}\text { No. of } \\
\text { participants }\end{array}$ & Statistical method & Effect size \\
\hline $\begin{array}{l}1 \mathrm{~N} \text { of pts with at least one relapse } \\
\text { at } 2 \mathrm{yrs}\end{array}$ & 2 & 2113 & Risk Ratio (M-H, Random, 95\% CI) & $0.57[0.47,0.69]$ \\
\hline 1.1 Natalizumab vs Placebo & 1 & 942 & Risk Ratio (M-H, Random, 95\% CI) & $0.51[0.44,0.61]$ \\
\hline $\begin{array}{l}1.2 \text { Natalizumab + IFN vs } \\
\text { IFN }\end{array}$ & 1 & 1171 & Risk Ratio (M-H, Random, 95\% CI) & $0.62[0.55,0.70]$ \\
\hline $2 \mathrm{~N}$ of pts who progressed at $2 \mathrm{yrs}$ & 2 & 2113 & Risk Ratio (M-H, Random, 95\% CI) & $0.74[0.62,0.89]$ \\
\hline 2.1 Natalizumab vs Placebo & 1 & 942 & Risk Ratio (M-H, Random, 95\% CI) & $0.67[0.55,0.81]$ \\
\hline $\begin{array}{l}2.2 \text { Natalizumab + IFN vs } \\
\text { IFN }\end{array}$ & 1 & 1171 & Risk Ratio (M-H, Random, 95\% CI) & $0.80[0.69,0.93]$ \\
\hline $\begin{array}{l}3 \text { PCS Change in Short Form } \\
\text { (SF-36) follow up } 2 \text { years }\end{array}$ & 2 & 2113 & Mean Difference (IV, Random, 95\% CI) & $1.98[1.05,2.91]$ \\
\hline 3.1 Natalizumab vs Placebo & 1 & 942 & Mean Difference (IV, Random, 95\% CI) & $2.01[0.48,3.54]$ \\
\hline $\begin{array}{l}3.2 \text { Natalizumab + IFN vs } \\
\text { IFN }\end{array}$ & 1 & 1171 & Mean Difference (IV, Random, 95\% CI) & $1.96[0.79,3.13]$ \\
\hline $\begin{array}{l}4 \text { MCS Change in Short Form } \\
\text { (SF-36) follow up } 2 \text { years }\end{array}$ & 2 & 2113 & Mean Difference (IV, Random, 95\% CI) & $1.38[0.33,2.42]$ \\
\hline 4.1 Natalizumab vs Placebo & 1 & 942 & Mean Difference (IV, Random, 95\% CI) & $2.53[0.00,5.06]$ \\
\hline $\begin{array}{l}4.2 \text { Natalizumab + IFN vs } \\
\text { IFN }\end{array}$ & 1 & 1171 & Mean Difference (IV, Random, 95\% CI) & $1.14[-0.00,2.28]$ \\
\hline
\end{tabular}

\section{Comparison 2. Secondary Efficacy Outcome (Natalizumab vs Control)}

\begin{tabular}{|c|c|c|c|c|}
\hline Outcome or subgroup title & $\begin{array}{l}\text { No. of } \\
\text { studies }\end{array}$ & $\begin{array}{c}\text { No. of } \\
\text { participants }\end{array}$ & Statistical method & Effect size \\
\hline $\begin{array}{l}1 \text { Change in Well-being (VAS) at } \\
2 \text { yrs }\end{array}$ & 1 & 942 & Mean Difference (IV, Random, 95\% CI) & $6.4[1.76,11.04]$ \\
\hline 1.1 Natalizumab vs Placebo & 1 & 942 & Mean Difference (IV, Random, 95\% CI) & $6.4[1.76,11.04]$ \\
\hline $\begin{array}{l}2 \mathrm{Gd} \text {-enhacing lesion (at least one) } \\
\text { at } 2 \mathrm{yrs}\end{array}$ & 2 & 2113 & Risk Ratio (M-H, Random, 95\% CI) & $0.12[0.09,0.17]$ \\
\hline 2.1 Natalizumab vs Placebo & 1 & 942 & Risk Ratio (M-H, Random, 95\% CI) & $0.11[0.07,0.17]$ \\
\hline $\begin{array}{l}2.2 \text { Natalizumab + IFN vs } \\
\text { IFN }\end{array}$ & 1 & 1171 & Risk Ratio (M-H, Random, 95\% CI) & $0.14[0.09,0.22]$ \\
\hline $\begin{array}{l}3 \text { Change of MRI T2 total lesion } \\
\text { load at } 2 \mathrm{yrs}\end{array}$ & 1 & 855 & Mean Difference (IV, Random, 95\% CI) & $\begin{array}{l}-3796.20[-5849.43, \\
-1742.97]\end{array}$ \\
\hline 3.1 Natalizumab vs Placebo & 1 & 855 & Mean Difference (IV, Random, 95\% CI) & $\begin{array}{l}-3796.20[-5849.43, \\
-1742.97]\end{array}$ \\
\hline
\end{tabular}




\begin{tabular}{|c|c|c|c|c|}
\hline Outcome or subgroup title & $\begin{array}{l}\text { No. of } \\
\text { studies }\end{array}$ & $\begin{array}{c}\text { No. of } \\
\text { participants }\end{array}$ & Statistical method & Effect size \\
\hline $\begin{array}{l}1 \mathrm{~N} \text { of pts with Severe AE over } 2 \\
\text { yrs }\end{array}$ & 2 & 2110 & Risk Ratio (M-H, Random, 95\% CI) & $0.92[0.81,1.04]$ \\
\hline 1.1 Natalizumab vs Placebo & 1 & 939 & Risk Ratio (M-H, Random, 95\% CI) & $0.85[0.68,1.08]$ \\
\hline $\begin{array}{l}\text { 1.2 Natalizumab + IFN vs } \\
\text { IFN }\end{array}$ & 1 & 1171 & Risk Ratio (M-H, Random, 95\% CI) & $0.95[0.81,1.10]$ \\
\hline $\begin{array}{l}2 \mathrm{~N} \text { of pts with Serious } \mathrm{AE} \\
\text { (irrespective of treatment } \\
\text { duration) }\end{array}$ & 3 & 2220 & Risk Ratio (M-H, Random, 95\% CI) & $0.83[0.70,0.98]$ \\
\hline 2.1 Natalizumab vs Placebo & 1 & 939 & Risk Ratio (M-H, Random, 95\% CI) & $0.79[0.61,1.02]$ \\
\hline $\begin{array}{l}2.2 \text { Natalizumab + IFN vs } \\
\text { IFN }\end{array}$ & 1 & 1171 & Risk Ratio (M-H, Random, 95\% CI) & $0.87[0.69,1.09]$ \\
\hline 2.3 Natalizumab + GA vs GA & 1 & 110 & Risk Ratio (M-H, Random, 95\% CI) & $0.5[0.05,5.36]$ \\
\hline $\begin{array}{l}3 \mathrm{~N} \text { of pts with serious } \mathrm{AE} \\
\text { (irrespective of treatment } \\
\text { duration - MS relapses } \\
\text { excluded) }\end{array}$ & 3 & 2220 & Risk Ratio (M-H, Random, 95\% CI) & $1.13[0.90,1.43]$ \\
\hline 3.1 Natalizumab vs Placebo & 1 & 939 & Risk Ratio (M-H, Random, 95\% CI) & $1.19[0.81,1.73]$ \\
\hline $\begin{array}{l}3.2 \text { Natalizumab + IFN vs } \\
\text { IFN }\end{array}$ & 1 & 1171 & Risk Ratio (M-H, Random, 95\% CI) & $1.10[0.81,1.49]$ \\
\hline 3.3 Natalizumab + GA vs GA & 1 & 110 & Risk Ratio (M-H, Random, 95\% CI) & $1.0[0.06,15.59]$ \\
\hline
\end{tabular}

\section{Comparison 4. Secondary Safety Outcome (Natalizumab vs Control)}

\begin{tabular}{|c|c|c|c|c|}
\hline Outcome or subgroup title & $\begin{array}{l}\text { No. of } \\
\text { studies }\end{array}$ & $\begin{array}{c}\text { No. of } \\
\text { participants }\end{array}$ & Statistical method & Effect size \\
\hline $\begin{array}{l}1 \mathrm{~N} \text { of pts with at least one } \mathrm{AE} \\
\text { (irrespective of treatment } \\
\text { duration) }\end{array}$ & 3 & 2220 & Risk Ratio (M-H, Random, 95\% CI) & $1.00[0.99,1.01]$ \\
\hline 1.1 Natalizumab vs Placebo & 1 & 939 & Risk Ratio (M-H, Random, 95\% CI) & $0.99[0.96,1.02]$ \\
\hline $\begin{array}{l}1.2 \text { Natalizumab + IFN vs } \\
\text { IFN }\end{array}$ & 1 & 1171 & Risk Ratio (M-H, Random, 95\% CI) & $1.00[0.99,1.01]$ \\
\hline 1.3 Natalizumab + GA vs GA & 1 & 110 & Risk Ratio (M-H, Random, 95\% CI) & $0.98[0.88,1.10]$ \\
\hline $\begin{array}{l}2 \text { Treatment Discontinuation } \\
\text { caused by AE (irrespective of } \\
\text { treatment duration) }\end{array}$ & 3 & 2220 & Risk Ratio (M-H, Random, 95\% CI) & $1.14[0.82,1.59]$ \\
\hline 2.1 Natalizumab vs Placebo & 1 & 939 & Risk Ratio (M-H, Random, 95\% CI) & $1.58[0.84,2.97]$ \\
\hline $\begin{array}{l}2.2 \text { Natalizumab + IFN vs } \\
\text { IFN }\end{array}$ & 1 & 1171 & Risk Ratio (M-H, Random, 95\% CI) & $1.01[0.68,1.50]$ \\
\hline 2.3 Natalizumab + GA vs GA & 1 & 110 & Risk Ratio (M-H, Random, 95\% CI) & $1.0[0.06,15.59]$ \\
\hline
\end{tabular}




\section{Comparison 5. Adverse Event Analysis}

\begin{tabular}{|c|c|c|c|c|}
\hline Outcome or subgroup title & $\begin{array}{l}\text { No. of } \\
\text { studies }\end{array}$ & $\begin{array}{c}\text { No. of } \\
\text { participants }\end{array}$ & Statistical method & Effect size \\
\hline 1 Headache & 3 & 2220 & Risk Ratio (M-H, Random, 95\% CI) & $1.08[0.97,1.20]$ \\
\hline 1.1 Natalizumab vs Placebo & 1 & 939 & Risk Ratio (M-H, Random, 95\% CI) & $1.15[0.95,1.39]$ \\
\hline 1.2 Natalizumab IFN vs IFN & 1 & 1171 & Risk Ratio (M-H, Random, 95\% CI) & $1.05[0.92,1.19]$ \\
\hline 1.3 Natalizumab + GA vs GA & 1 & 110 & Risk Ratio (M-H, Random, 95\% CI) & $1.13[0.63,2.03]$ \\
\hline 2 Pain in arms or legs - Arthralgia & 3 & 2220 & Risk Ratio (M-H, Fixed, 95\% CI) & $1.17[0.98,1.40]$ \\
\hline 2.1 Natalizumab vs Placebo & 1 & 939 & Risk Ratio (M-H, Fixed, 95\% CI) & $1.35[0.98,1.85]$ \\
\hline $\begin{array}{l}2.2 \text { Natalizumab + IFN vs } \\
\text { IFN }\end{array}$ & 1 & 1171 & Risk Ratio (M-H, Fixed, 95\% CI) & $1.05[0.85,1.31]$ \\
\hline 2.3 Natalizumab + GA vs GA & 1 & 110 & Risk Ratio (M-H, Fixed, 95\% CI) & $5.0[0.60,41.42]$ \\
\hline 3 Depression & 3 & 2220 & Risk Ratio (M-H, Random, 95\% CI) & $1.18[0.98,1.41]$ \\
\hline 3.1 Natalizumab vs Placebo & 1 & 939 & Risk Ratio (M-H, Random, 95\% CI) & $1.18[0.88,1.60]$ \\
\hline $\begin{array}{l}3.2 \text { Natalizumab + IFN vs } \\
\text { IFN }\end{array}$ & 1 & 1171 & Risk Ratio (M-H, Random, 95\% CI) & $1.17[0.92,1.47]$ \\
\hline 3.3 Natalizumab + GA vs GA & 1 & 110 & Risk Ratio (M-H, Random, 95\% CI) & $1.5[0.26,8.63]$ \\
\hline 4 Anxiety & 1 & 1171 & Risk Ratio (M-H, Random, 95\% CI) & $1.49[1.05,2.12]$ \\
\hline $\begin{array}{l}\text { 4.1 Natalizumab + IFN vs } \\
\text { IFN }\end{array}$ & 1 & 1171 & Risk Ratio (M-H, Random, 95\% CI) & $1.49[1.05,2.12]$ \\
\hline 5 Insomnia & 1 & 1171 & Risk Ratio (M-H, Random, 95\% CI) & $1.06[0.82,1.36]$ \\
\hline $\begin{array}{l}5.1 \text { Natalizumab + IFN vs } \\
\text { IFN }\end{array}$ & 1 & 1171 & Risk Ratio (M-H, Random, 95\% CI) & $1.06[0.82,1.36]$ \\
\hline 6 Influenza Like Illness & 1 & 1171 & Risk Ratio (M-H, Random, 95\% CI) & $1.05[0.83,1.33]$ \\
\hline $\begin{array}{l}\text { 6.1 Natalizumab + IFN vs } \\
\text { IFN }\end{array}$ & 1 & 1171 & Risk Ratio (M-H, Random, 95\% CI) & $1.05[0.83,1.33]$ \\
\hline 7 Nasopharyngitis & 2 & 1281 & Risk Ratio (M-H, Fixed, 95\% CI) & $1.09[0.94,1.26]$ \\
\hline $\begin{array}{l}\text { 7.1 Natalizumab + IFN vs } \\
\text { IFN }\end{array}$ & 1 & 1171 & Risk Ratio (M-H, Fixed, 95\% CI) & $1.11[0.96,1.29]$ \\
\hline 7.2 Natalizumab + GA vs GA & 1 & 110 & Risk Ratio (M-H, Fixed, 95\% CI) & $0.64[0.27,1.52]$ \\
\hline 8 Pharyngitis & 2 & 2110 & Risk Ratio (M-H, Random, 95\% CI) & $1.41[0.98,2.04]$ \\
\hline 8.1 Natalizumab vs Placebo & 1 & 939 & Risk Ratio (M-H, Random, 95\% CI) & $1.20[0.81,1.79]$ \\
\hline $\begin{array}{l}8.2 \text { Natalizumab + IFN vs } \\
\text { IFN }\end{array}$ & 1 & 1171 & Risk Ratio (M-H, Random, 95\% CI) & $1.76[1.07,2.90]$ \\
\hline 9 Sinusitis & 2 & 1281 & Risk Ratio (M-H, Random, 95\% CI) & $1.29[0.88,1.88]$ \\
\hline $\begin{array}{l}\text { 9.1 Natalizumab + IFN vs } \\
\text { IFN }\end{array}$ & 1 & 1171 & Risk Ratio (M-H, Random, 95\% CI) & $1.20[0.93,1.56]$ \\
\hline 9.2 Natalizumab + GA vs GA & 1 & 110 & Risk Ratio (M-H, Random, 95\% CI) & $2.25[0.74,6.87]$ \\
\hline 10 Sinus Congestion & 1 & 1171 & Risk Ratio (M-H, Random, 95\% CI) & $2.03[1.15,3.59]$ \\
\hline $\begin{array}{l}\text { 10.1 Natalizumab + IFN vs } \\
\text { IFN }\end{array}$ & 1 & 1171 & Risk Ratio (M-H, Random, 95\% CI) & $2.03[1.15,3.59]$ \\
\hline 11 Sinus Headache & 1 & 1171 & Risk Ratio (M-H, Random, 95\% CI) & $1.69[0.94,3.03]$ \\
\hline $\begin{array}{l}\text { 11.1 Natalizumab + IFN vs } \\
\text { IFN }\end{array}$ & 1 & 1171 & Risk Ratio (M-H, Random, 95\% CI) & $1.69[0.94,3.03]$ \\
\hline 12 Upper Respiratory Infection & 3 & 2220 & Risk Ratio (M-H, Random, 95\% CI) & $1.05[0.87,1.28]$ \\
\hline 12.1 Natalizumab vs Placebo & 1 & 939 & Risk Ratio (M-H, Random, 95\% CI) & $1.00[0.80,1.26]$ \\
\hline $\begin{array}{l}\text { 12.2 Natalizumab + IFN vs } \\
\text { IFN }\end{array}$ & 1 & 1171 & Risk Ratio (M-H, Random, 95\% CI) & $1.13[0.76,1.69]$ \\
\hline
\end{tabular}

Natalizumab for relapsing remitting multiple sclerosis (Review)

Copyright @ 20 I I The Cochrane Collaboration. Published by John Wiley \& Sons, Ltd. 


\begin{tabular}{|c|c|c|c|c|}
\hline $\begin{array}{l}\text { 12.3 Natalizumab + GA vs } \\
\text { GA }\end{array}$ & 1 & 110 & Risk Ratio (M-H, Random, 95\% CI) & $1.8[0.64,5.03]$ \\
\hline 13 Influenza & 1 & 1171 & Risk Ratio (M-H, Random, 95\% CI) & $1.14[0.87,1.48]$ \\
\hline $\begin{array}{l}13.1 \text { Natalizumab + IFN vs } \\
\text { IFN }\end{array}$ & 1 & 1171 & Risk Ratio (M-H, Random, 95\% CI) & $1.14[0.87,1.48]$ \\
\hline 14 Cough & 1 & 1171 & Risk Ratio (M-H, Random, 95\% CI) & $1.24[0.87,1.75]$ \\
\hline $\begin{array}{l}14.1 \text { Natalizumab + IFN vs } \\
\text { IFN }\end{array}$ & 1 & 1171 & Risk Ratio (M-H, Random, 95\% CI) & $1.24[0.87,1.75]$ \\
\hline 15 Diarrhea & 1 & 1171 & Risk Ratio (M-H, Random, 95\% CI) & $1.19[0.93,1.53]$ \\
\hline $\begin{array}{l}15.1 \text { Natalizumab + IFN vs } \\
\text { IFN }\end{array}$ & 1 & 1171 & Risk Ratio (M-H, Random, 95\% CI) & $1.19[0.93,1.53]$ \\
\hline 16 Nausea & 2 & 1281 & Risk Ratio (M-H, Random, 95\% CI) & $1.13[0.88,1.46]$ \\
\hline $\begin{array}{l}\text { 16.1 Natalizumab + IFN vs } \\
\text { IFN }\end{array}$ & 1 & 1171 & Risk Ratio (M-H, Random, 95\% CI) & $1.14[0.87,1.48]$ \\
\hline $\begin{array}{l}\text { 16.2 Natalizumab + GA vs } \\
\text { GA }\end{array}$ & 1 & 110 & Risk Ratio (M-H, Random, 95\% CI) & $1.13[0.47,2.70]$ \\
\hline 17 Vomiting & 1 & 1171 & Risk Ratio (M-H, Random, 95\% CI) & $1.40[0.88,2.22]$ \\
\hline $\begin{array}{l}\text { 17.1 Natalizumab + IFN vs } \\
\text { IFN }\end{array}$ & 1 & 1171 & Risk Ratio (M-H, Random, 95\% CI) & $1.40[0.88,2.22]$ \\
\hline 18 Abdominal Pain or Discomfort & 2 & 2110 & Risk Ratio (M-H, Random, 95\% CI) & $1.14[0.84,1.55]$ \\
\hline 18.1 Natalizumab vs Placebo & 1 & 939 & Risk Ratio (M-H, Random, 95\% CI) & $1.11[0.74,1.65]$ \\
\hline $\begin{array}{l}18.2 \text { Natalizumab + IFN vs } \\
\text { IFN }\end{array}$ & 1 & 1171 & Risk Ratio (M-H, Random, 95\% CI) & $1.19[0.74,1.92]$ \\
\hline 19 Muscle Cramp & 1 & 1171 & Risk Ratio (M-H, Random, 95\% CI) & $1.19[0.74,1.92]$ \\
\hline $\begin{array}{l}19.1 \text { Natalizumab + IFN vs } \\
\text { IFN }\end{array}$ & 1 & 1171 & Risk Ratio (M-H, Random, 95\% CI) & $1.19[0.74,1.92]$ \\
\hline 20 Myalgia & 1 & 1171 & Risk Ratio (M-H, Random, 95\% CI) & $1.31[0.95,1.81]$ \\
\hline $\begin{array}{l}20.1 \text { Natalizumab + IFN vs } \\
\text { IFN }\end{array}$ & 1 & 1171 & Risk Ratio (M-H, Random, 95\% CI) & $1.31[0.95,1.81]$ \\
\hline 21 Seasonal Allergy & 1 & 1171 & Risk Ratio (M-H, Random, 95\% CI) & $1.50[0.90,2.51]$ \\
\hline $\begin{array}{l}21.1 \text { Natalizumab + IFN vs } \\
\text { IFN }\end{array}$ & 1 & 1171 & Risk Ratio (M-H, Random, 95\% CI) & $1.50[0.90,2.51]$ \\
\hline 22 Peripheral Edema & 1 & 1171 & Risk Ratio (M-H, Random, 95\% CI) & $4.78[2.00,11.42]$ \\
\hline $\begin{array}{l}22.1 \text { Natalizumab + IFN vs } \\
\text { IFN }\end{array}$ & 1 & 1171 & Risk Ratio (M-H, Random, 95\% CI) & $4.78[2.00,11.42]$ \\
\hline 23 Tremor & 2 & 2110 & Risk Ratio (M-H, Random, 95\% CI) & $1.42[0.89,2.27]$ \\
\hline 23.1 Natalizumab vs Placebo & 1 & 939 & Risk Ratio (M-H, Random, 95\% CI) & $1.05[0.48,2.29]$ \\
\hline $\begin{array}{l}23.2 \text { Natalizumab + IFN vs } \\
\text { IFN }\end{array}$ & 1 & 1171 & Risk Ratio (M-H, Random, 95\% CI) & $1.69[0.94,3.03]$ \\
\hline 24 Flushing & 1 & 110 & Risk Ratio (M-H, Random, 95\% CI) & $6.00[0.75,48.21]$ \\
\hline 24.1 Natalizumab GA vs GA & 1 & 110 & Risk Ratio (M-H, Random, 95\% CI) & $6.00[0.75,48.21]$ \\
\hline 25 Fatigue - Myasthenia & 1 & 939 & Risk Ratio (M-H, Random, 95\% CI) & $1.27[0.99,1.64]$ \\
\hline 25.1 Natalizumab vs Placebo & 1 & 939 & Risk Ratio (M-H, Random, 95\% CI) & $1.27[0.99,1.64]$ \\
\hline 26 Urinary Urgency / Frequency & 1 & 939 & Risk Ratio (M-H, Random, 95\% CI) & $1.27[0.79,2.03]$ \\
\hline 26.1 Natalizumab vs Placebo & 1 & 939 & Risk Ratio (M-H, Random, 95\% CI) & $1.27[0.79,2.03]$ \\
\hline 27 Hypersensitivity reactions & 3 & 2220 & Risk Ratio (M-H, Random, 95\% CI) & $3.43[0.33,36.07]$ \\
\hline 27.1 Natalizumab vs Placebo & 1 & 939 & Risk Ratio (M-H, Random, 95\% CI) & $25.42[1.55,416.15]$ \\
\hline $\begin{array}{l}27.2 \text { Natalizumab + IFN vs } \\
\text { IFN }\end{array}$ & 1 & 1171 & Risk Ratio (M-H, Random, 95\% CI) & $5.43[1.21,24.41]$ \\
\hline 27.3 Natalizumab GA vs GA & 1 & 110 & Risk Ratio (M-H, Random, 95\% CI) & $0.2[0.01,4.07]$ \\
\hline 28 Chest Discomfort & 1 & 939 & Risk Ratio (M-H, Random, 95\% CI) & $1.71[0.83,3.56]$ \\
\hline 28.1 Natalizumab vs Placebo & 1 & 939 & Risk Ratio (M-H, Random, 95\% CI) & $1.71[0.83,3.56]$ \\
\hline
\end{tabular}




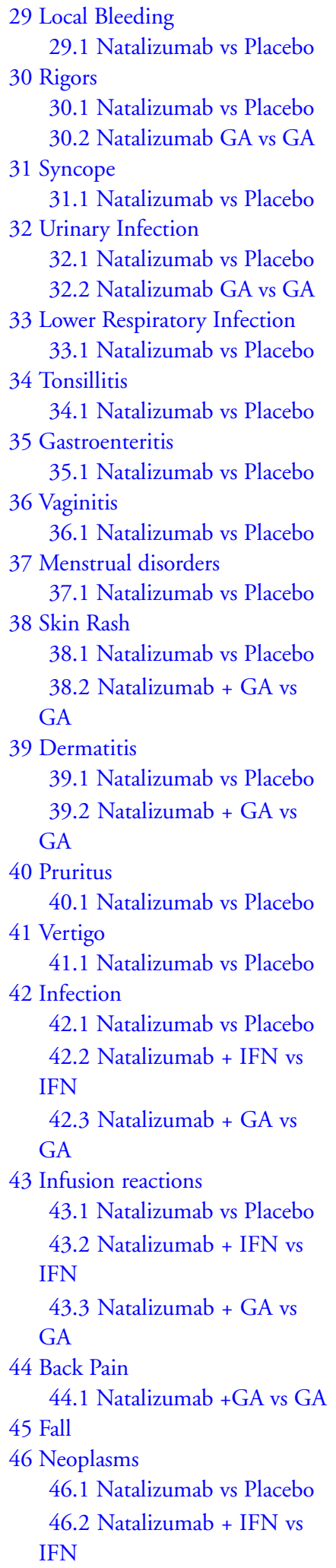

Risk Ratio (M-H, Random, 95\% CI)

$1.58[0.64,3.91]$ Risk Ratio (M-H, Random, 95\% CI) Risk Ratio (M-H, Random, 95\% CI) Risk Ratio (M-H, Random, 95\% CI) Risk Ratio (M-H, Random, 95\% CI) Risk Ratio (M-H, Random, 95\% CI) Risk Ratio (M-H, Random, 95\% CI) Risk Ratio (M-H, Random, 95\% CI) Risk Ratio (M-H, Random, 95\% CI) Risk Ratio (M-H, Random, 95\% CI) Risk Ratio (M-H, Random, 95\% CI) Risk Ratio (M-H, Random, 95\% CI) Risk Ratio (M-H, Random, 95\% CI) Risk Ratio (M-H, Random, 95\% CI) Risk Ratio (M-H, Random, 95\% CI) Risk Ratio (M-H, Random, 95\% CI) Risk Ratio (M-H, Random, 95\% CI) Risk Ratio (M-H, Random, 95\% CI) Risk Ratio (M-H, Random, 95\% CI) Risk Ratio (M-H, Random, 95\% CI) Risk Ratio (M-H, Random, 95\% CI) Risk Ratio (M-H, Random, 95\% CI) Risk Ratio (M-H, Random, 95\% CI)

Risk Ratio (M-H, Random, 95\% CI) Risk Ratio (M-H, Random, 95\% CI) Risk Ratio (M-H, Random, 95\% CI)

Risk Ratio (M-H, Random, 95\% CI) Risk Ratio (M-H, Random, 95\% CI) Risk Ratio (M-H, Random, 95\% CI) Risk Ratio (M-H, Random, 95\% CI) Risk Ratio (M-H, Random, 95\% CI) Risk Ratio (M-H, Random, 95\% CI) Risk Ratio (M-H, Random, 95\% CI)

Risk Ratio (M-H, Random, 95\% CI)

Risk Ratio (M-H, Random, 95\% CI) Risk Ratio (M-H, Random, 95\% CI) Risk Ratio (M-H, Random, 95\% CI)

Risk Ratio (M-H, Random, 95\% CI)

Risk Ratio (M-H, Random, 95\% CI) Risk Ratio (M-H, Random, 95\% CI) Risk Ratio (M-H, Random, 95\% CI) Risk Ratio (M-H, Random, 95\% CI) Risk Ratio (M-H, Random, 95\% CI) Risk Ratio (M-H, Random, 95\% CI)
$1.58[0.64,3.91]$

$3.54[1.16,10.83]$

$3.15[0.94,10.57]$

$7.0[0.37,132.40]$

$1.05[0.48,2.29]$

$1.05[0.48,2.29]$

$0.99[0.51,1.93]$

$1.17[0.88,1.57]$

$0.5[0.13,1.90]$

$1.06[0.78,1.45]$

$1.06[0.78,1.45]$

$1.37[0.78,2.39]$

$1.37[0.78,2.39]$

$1.23[0.81,1.86]$

$1.23[0.81,1.86]$

$1.65[1.01,2.71]$

$1.65[1.01,2.71]$

1.89 [1.09, 3.29]

1.89 [1.09, 3.29]

$1.94[0.47,7.99]$

$1.23[0.81,1.86]$

$6.00[0.75,48.21]$

$2.15[0.96,4.85]$

$1.82[0.98,3.40]$

$6.00[0.75,48.21]$

$2.07[0.86,5.00]$

$2.07[0.86,5.00]$

$1.18[0.67,2.09]$

$1.18[0.67,2.09]$

$1.01[0.97,1.06]$

$1.00[0.93,1.07]$

$1.03[0.97,1.08]$

$0.92[0.69,1.22]$

$1.24[1.05,1.47]$

1.34 [1.01, 1.77]

$1.20[0.97,1.49]$

$0.86[0.31,2.39]$

$2.25[0.74,6.87]$

$2.25[0.74,6.87]$

$2.69[0.32,22.39]$

$0.83[0.19,3.66]$

$2.49[0.29,21.20]$

$0.49[0.19,1.31]$ 


\begin{tabular}{|c|c|c|c|c|}
\hline $\begin{array}{l}46.3 \text { Natalizumab + GA vs } \\
\text { GA }\end{array}$ & 1 & 110 & Risk Ratio (M-H, Random, 95\% CI) & $0.0[0.0,0.0]$ \\
\hline 47 Abnormal liver function tests & 1 & 939 & Risk Ratio (M-H, Random, 95\% CI) & $1.29[0.67,2.47]$ \\
\hline 47.1 Natalizumab vs Placebo & 1 & 939 & Risk Ratio (M-H, Random, 95\% CI) & $1.29[0.67,2.47]$ \\
\hline 48 Death & 3 & 2220 & Risk Ratio (M-H, Random, 95\% CI) & $0.92[0.14,6.04]$ \\
\hline 48.1 Natalizumab vs Placebo & 1 & 939 & Risk Ratio (M-H, Random, 95\% CI) & $2.49[0.12,51.75]$ \\
\hline $\begin{array}{l}48.2 \text { Natalizumab + GA vs } \\
\text { GA }\end{array}$ & 1 & 110 & Risk Ratio (M-H, Random, 95\% CI) & $0.0[0.0,0.0]$ \\
\hline $\begin{array}{l}48.3 \text { Natalizumab + IFN vs } \\
\text { IFN }\end{array}$ & 1 & 1171 & Risk Ratio (M-H, Random, 95\% CI) & $0.49[0.04,5.43]$ \\
\hline $49 \mathrm{MS}$ relapse as a serious $\mathrm{AE}$ & 3 & 2220 & Risk Ratio (M-H, Random, 95\% CI) & $0.50[0.37,0.68]$ \\
\hline 49.1 Natalizumab vs Placebo & 1 & 939 & Risk Ratio (M-H, Random, 95\% CI) & $0.46[0.30,0.70]$ \\
\hline $\begin{array}{l}49.2 \text { Natalizumab + IFN vs } \\
\text { IFN }\end{array}$ & 1 & 1171 & Risk Ratio (M-H, Random, 95\% CI) & $0.55[0.36,0.86]$ \\
\hline $\begin{array}{l}49.3 \text { Natalizumab + GA vs } \\
\text { GA }\end{array}$ & 1 & 110 & Risk Ratio (M-H, Random, 95\% CI) & $0.33[0.01,8.01]$ \\
\hline
\end{tabular}

\section{Analysis I.I. Comparison I Primary Efficacy Outcome (Natalizumab vs Control), Outcome I N of pts with at least one relapse at 2 yrs.}

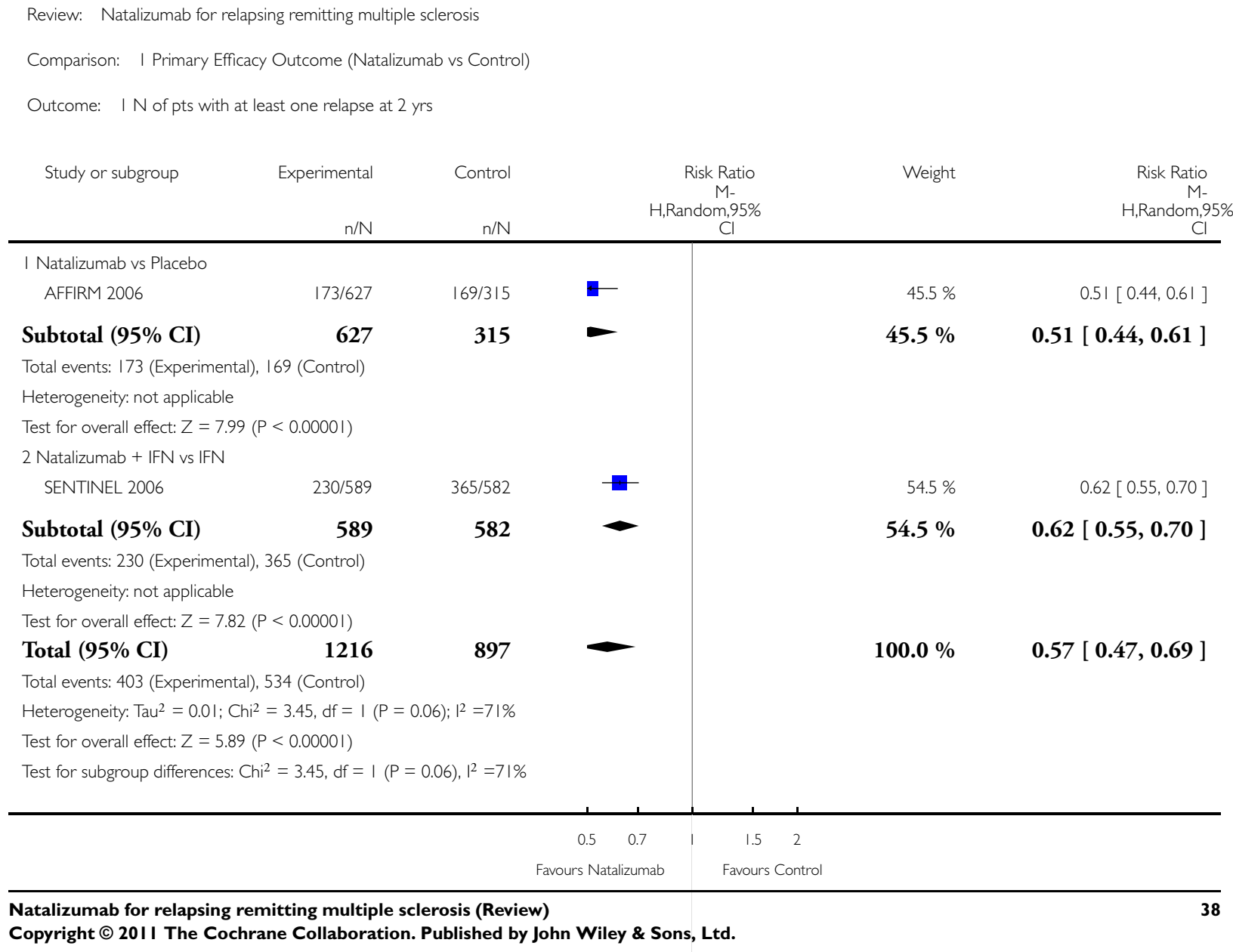

$173 / 627 \quad 169 / 315 \quad-$

\section{$\begin{array}{lllll}0.5 & 0.7 & \text { I } & 1.5 & 2\end{array}$}

Favours Natalizumab Favours Control 


\section{Analysis I.2. Comparison I Primary Efficacy Outcome (Natalizumab vs Control), Outcome 2 N of pts who progressed at 2 yrs.}

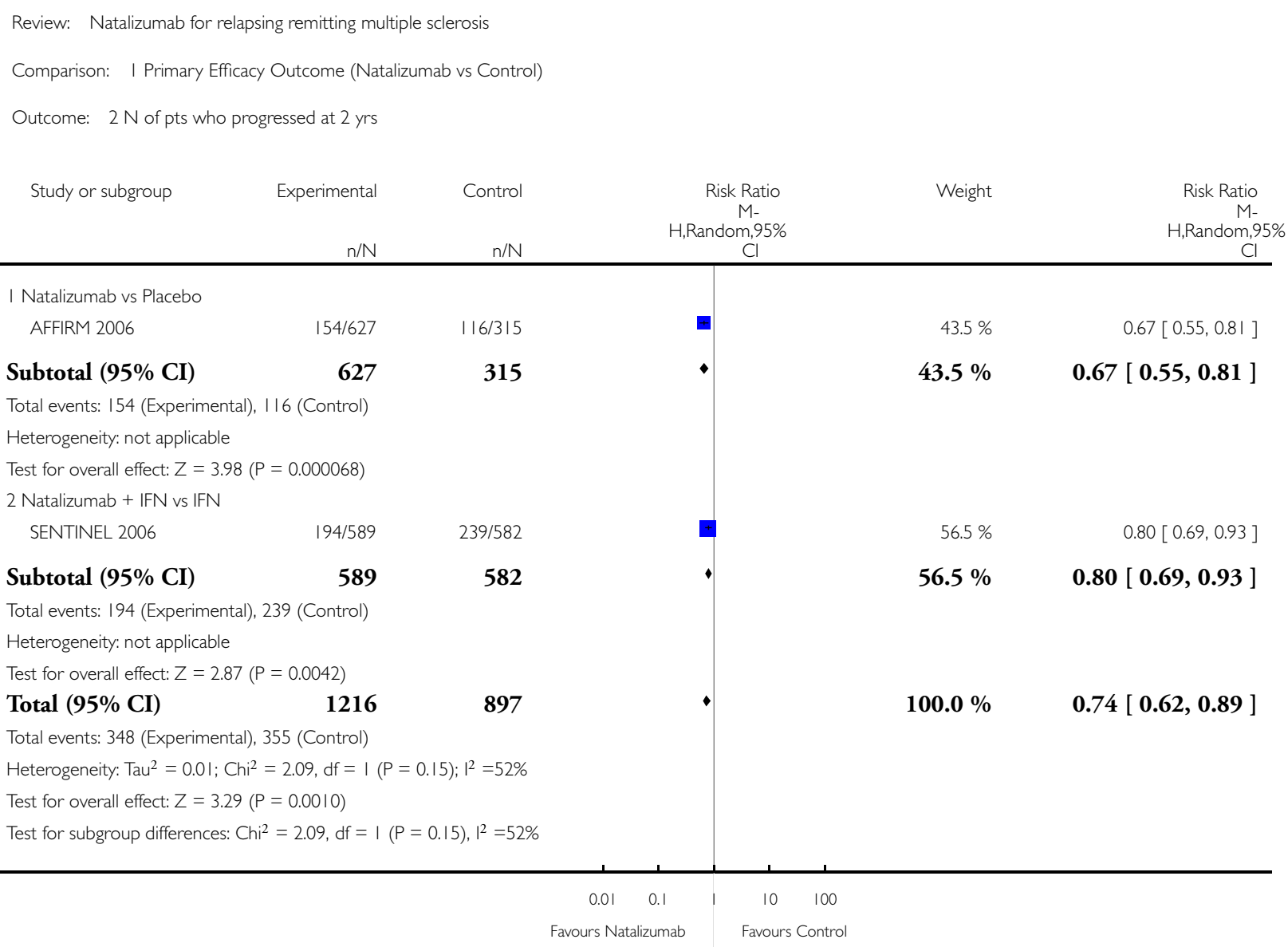




\section{Analysis I.3. Comparison I Primary Efficacy Outcome (Natalizumab vs Control), Outcome 3 PCS Change in Short Form (SF-36) follow up 2 years.}

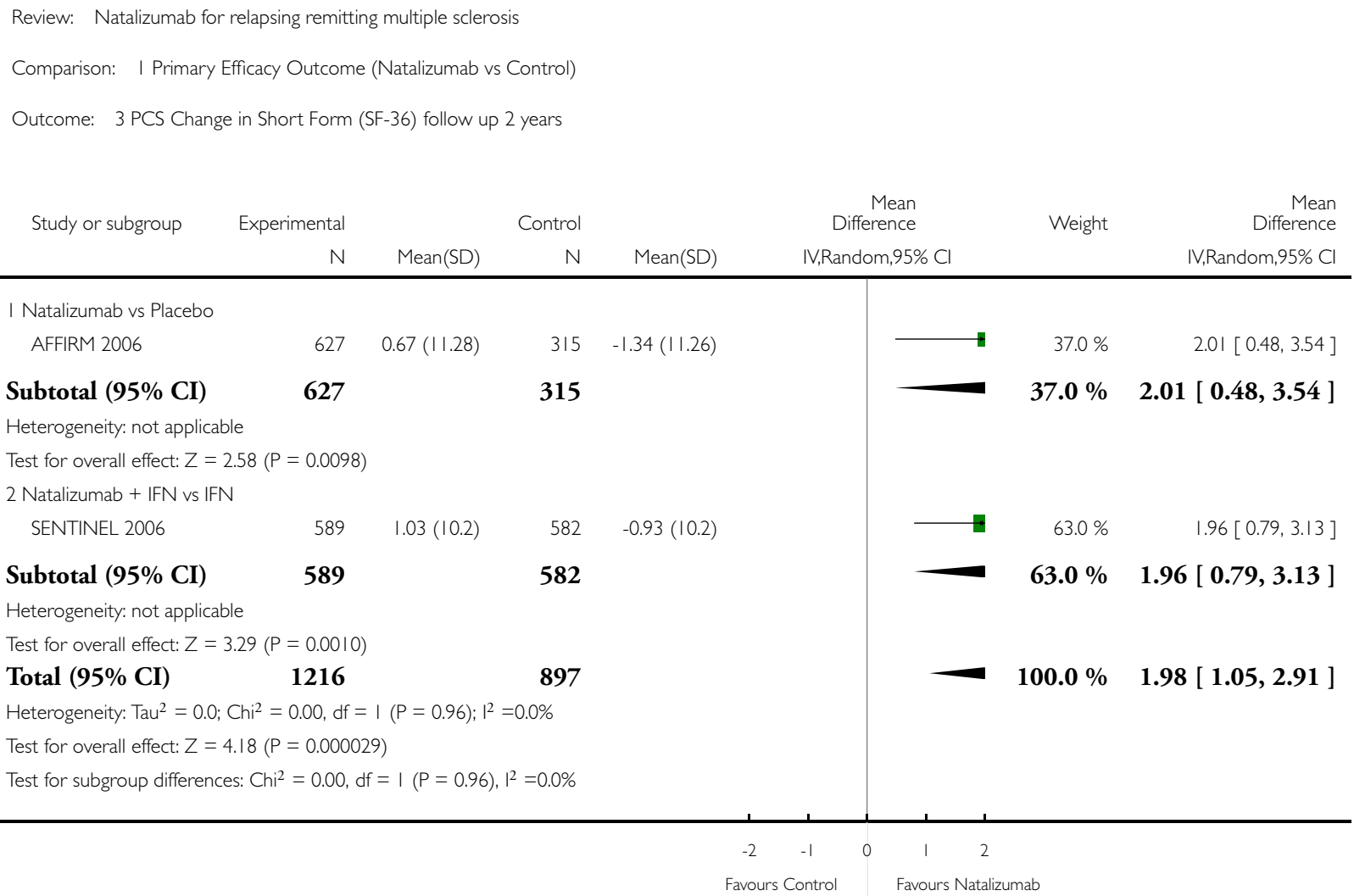




\section{Analysis I.4. Comparison I Primary Efficacy Outcome (Natalizumab vs Control), Outcome 4 MCS Change}

in Short Form (SF-36) follow up 2 years.

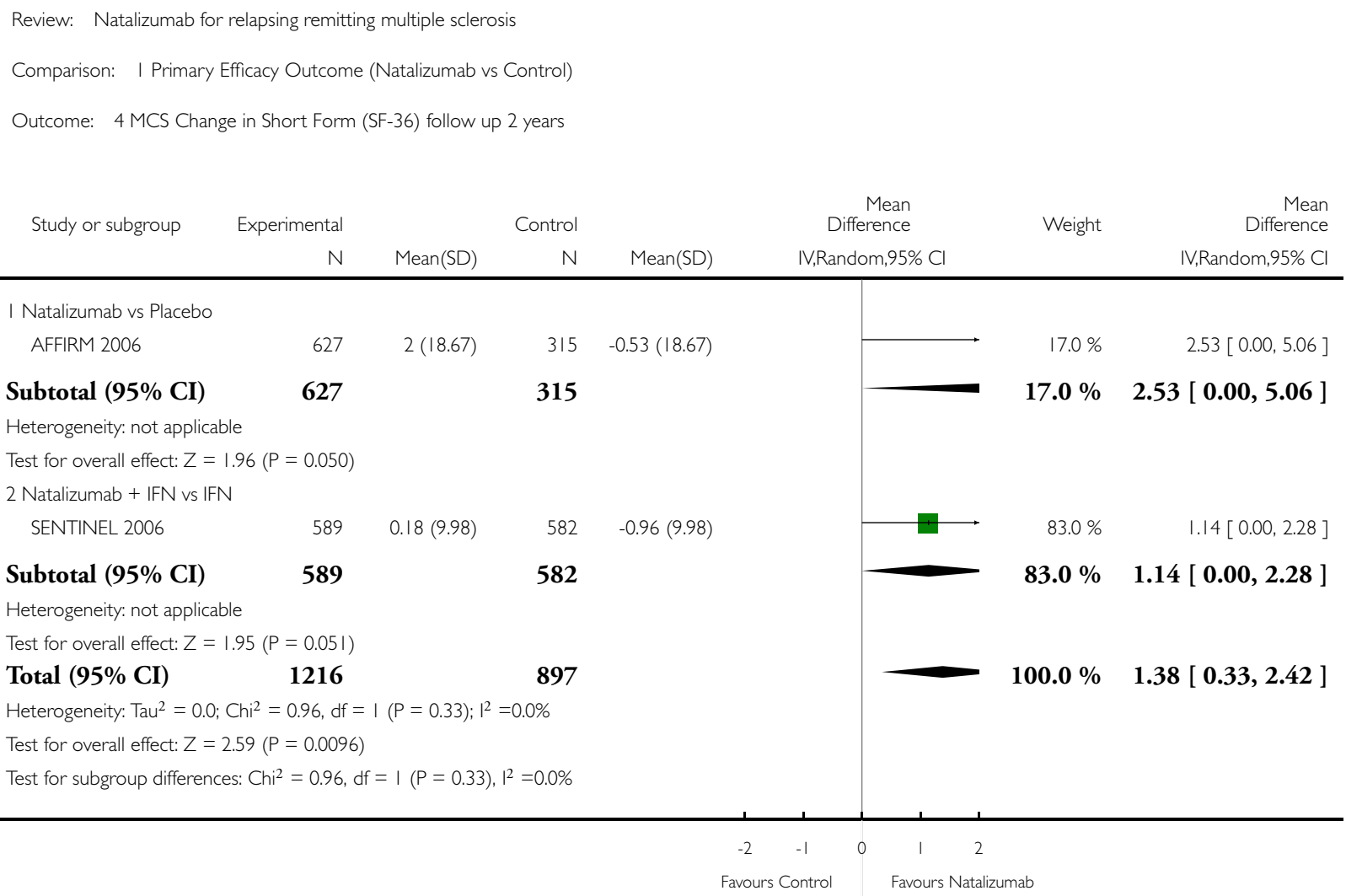


Analysis 2.1. Comparison 2 Secondary Efficacy Outcome (Natalizumab vs Control), Outcome I Change in Well-being (VAS) at 2 yrs.

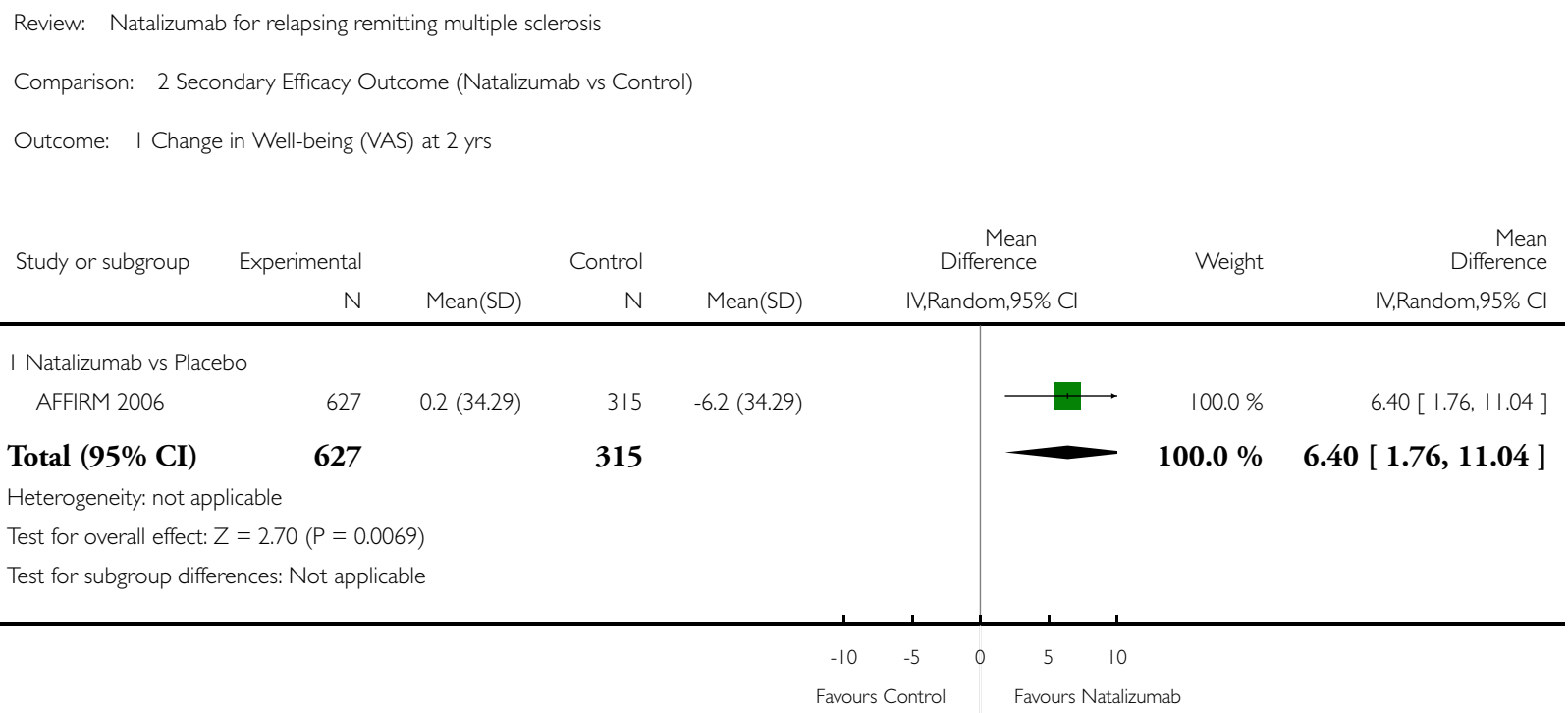




\section{Analysis 2.2. Comparison 2 Secondary Efficacy Outcome (Natalizumab vs Control), Outcome 2 Gd-}

enhacing lesion (at least one) at 2 yrs.

\begin{tabular}{|c|c|c|c|c|c|}
\hline \multicolumn{6}{|c|}{ Comparison: 2 Secondary Efficacy Outcome (Natalizumab vs Control) } \\
\hline \multicolumn{6}{|c|}{ Outcome: 2 Gd-enhacing lesion (at least one) at 2 yrs } \\
\hline Study or subgroup & $\begin{array}{r}\text { Experimental } \\
n / N \\
\end{array}$ & $\begin{array}{r}\text { Control } \\
n / N \\
\end{array}$ & $\begin{array}{c}\text { Risk Ratio } \\
\text { M- } \\
\text { H,Random,95\% } \\
\text { Cl }\end{array}$ & Weight & $\begin{array}{c}\text { Risk Ratio } \\
\text { M- } \\
\text { H,Random,95\% } \\
\text { Cl }\end{array}$ \\
\hline \multicolumn{6}{|l|}{ I Natalizumab vs Placebo } \\
\hline AFFIRM 2006 & $22 / 627$ & $102 / 315$ & \# & $50.3 \%$ & $0.11[0.07,0.17]$ \\
\hline Subtotal $(95 \% \mathrm{CI})$ & 627 & 315 & - & $50.3 \%$ & $0.11[0.07,0.17]$ \\
\hline \multicolumn{6}{|c|}{ Total events: 22 (Experimental), 102 (Control) } \\
\hline \multicolumn{6}{|c|}{ Heterogeneity: not applicable } \\
\hline \multicolumn{6}{|c|}{ Test for overall effect: $Z=9.89(P<0.0000 \mathrm{I})$} \\
\hline \multicolumn{6}{|l|}{2 Natalizumab + IFN vs IFN } \\
\hline SENTINEL 2006 & $21 / 589$ & $147 / 582$ & 毒 & $49.7 \%$ & $0.14[0.09,0.22]$ \\
\hline Subtotal $(95 \% \mathrm{CI})$ & 589 & 582 & $\hookrightarrow$ & $49.7 \%$ & $0.14[0.09,0.22]$ \\
\hline \multicolumn{6}{|c|}{ Total events: 21 (Experimental), I 47 (Control) } \\
\hline \multicolumn{6}{|c|}{ Heterogeneity: not applicable } \\
\hline \multicolumn{6}{|c|}{ Test for overall effect: $Z=8.67$ ( $P<0.0000 \mathrm{I})$} \\
\hline Total $(95 \% \mathrm{CI})$ & 1216 & 897 & $\bullet$ & $100.0 \%$ & $0.12[0.09,0.17]$ \\
\hline \multicolumn{6}{|c|}{ Total events: 43 (Experimental), 249 (Control) } \\
\hline \multicolumn{6}{|c|}{ Heterogeneity: $\mathrm{Tau}^{2}=0.0 ; \mathrm{Ch}^{2}=0.70, \mathrm{df}=\mathrm{I}(\mathrm{P}=0.40) ; \mathrm{I}^{2}=0.0 \%$} \\
\hline \multicolumn{6}{|c|}{ Test for overall effect: $Z=13.13(P<0.0000 \mid)$} \\
\hline Test for subgroup differen & $2=0.69, \mathrm{df}=1$ & 1), $\left.\right|^{2}=0.0 \%$ & & & \\
\hline
\end{tabular}


Analysis 2.3. Comparison 2 Secondary Efficacy Outcome (Natalizumab vs Control), Outcome 3 Change of MRI T2 total lesion load at 2 yrs.

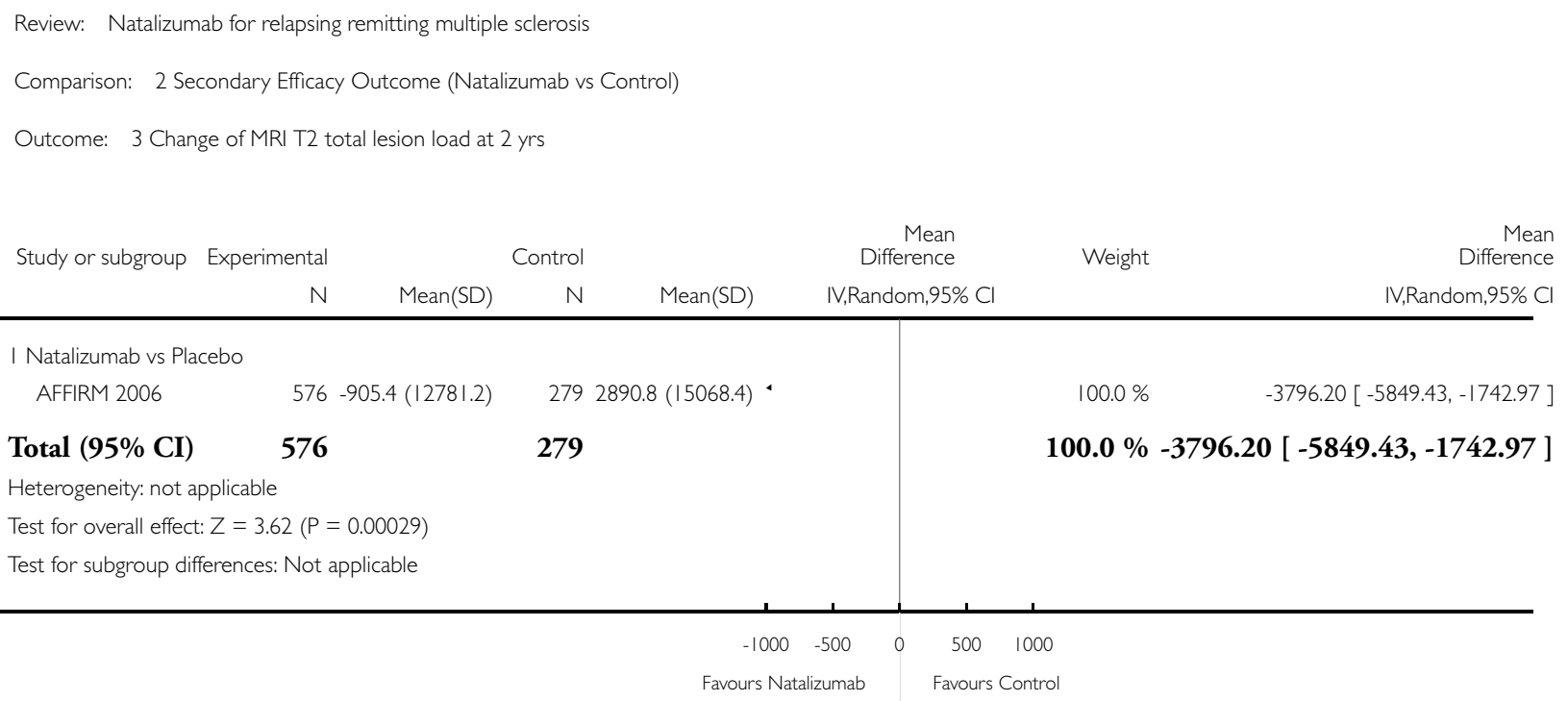




\section{Analysis 3.I. Comparison 3 Primary Safety Outcome (Natalizumab vs Control), Outcome I N of pts with}

Severe AE over 2 yrs.

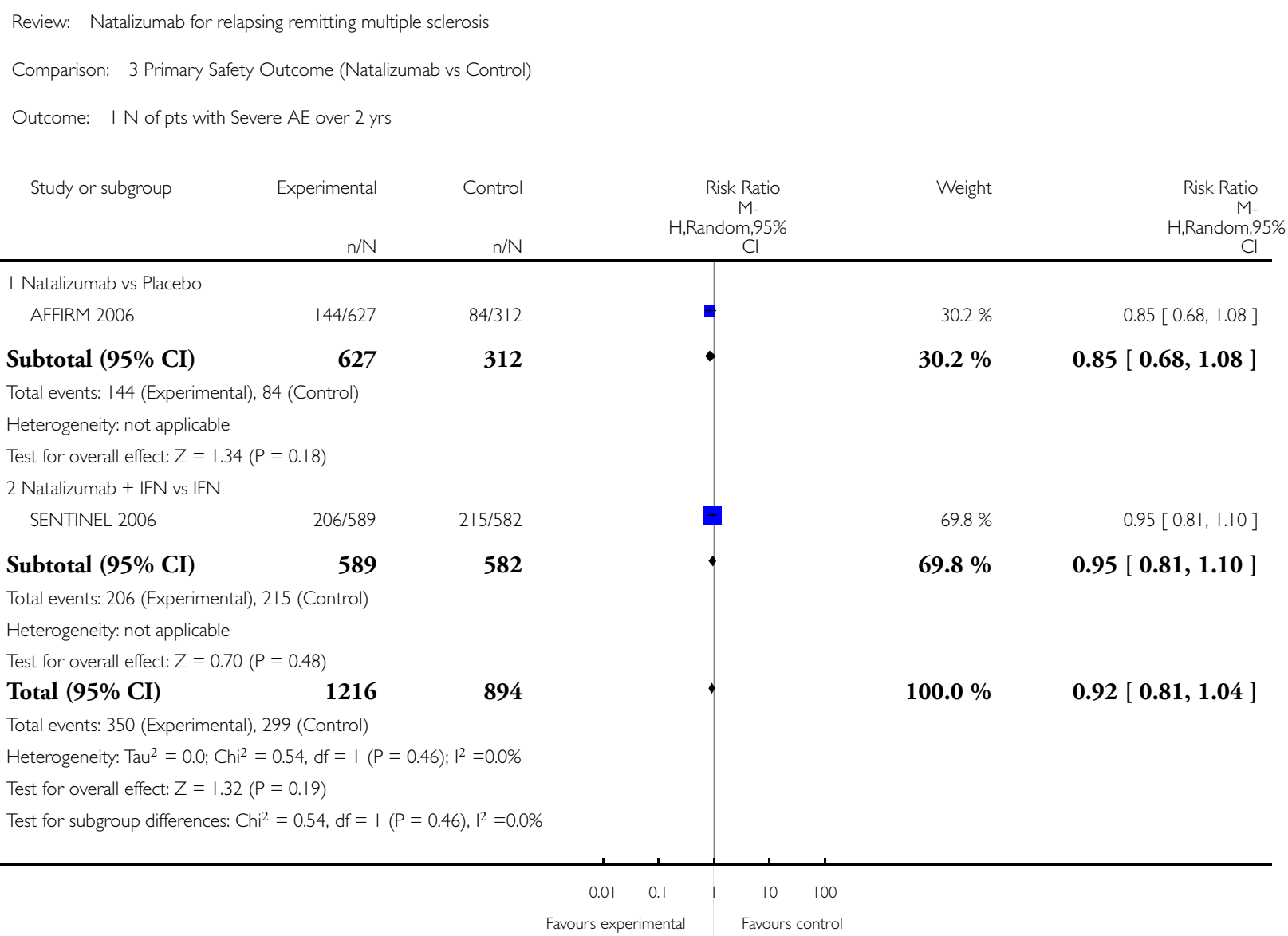




\section{Analysis 3.2. Comparison 3 Primary Safety Outcome (Natalizumab vs Control), Outcome 2 N of pts with Serious AE (irrespective of treatment duration).}

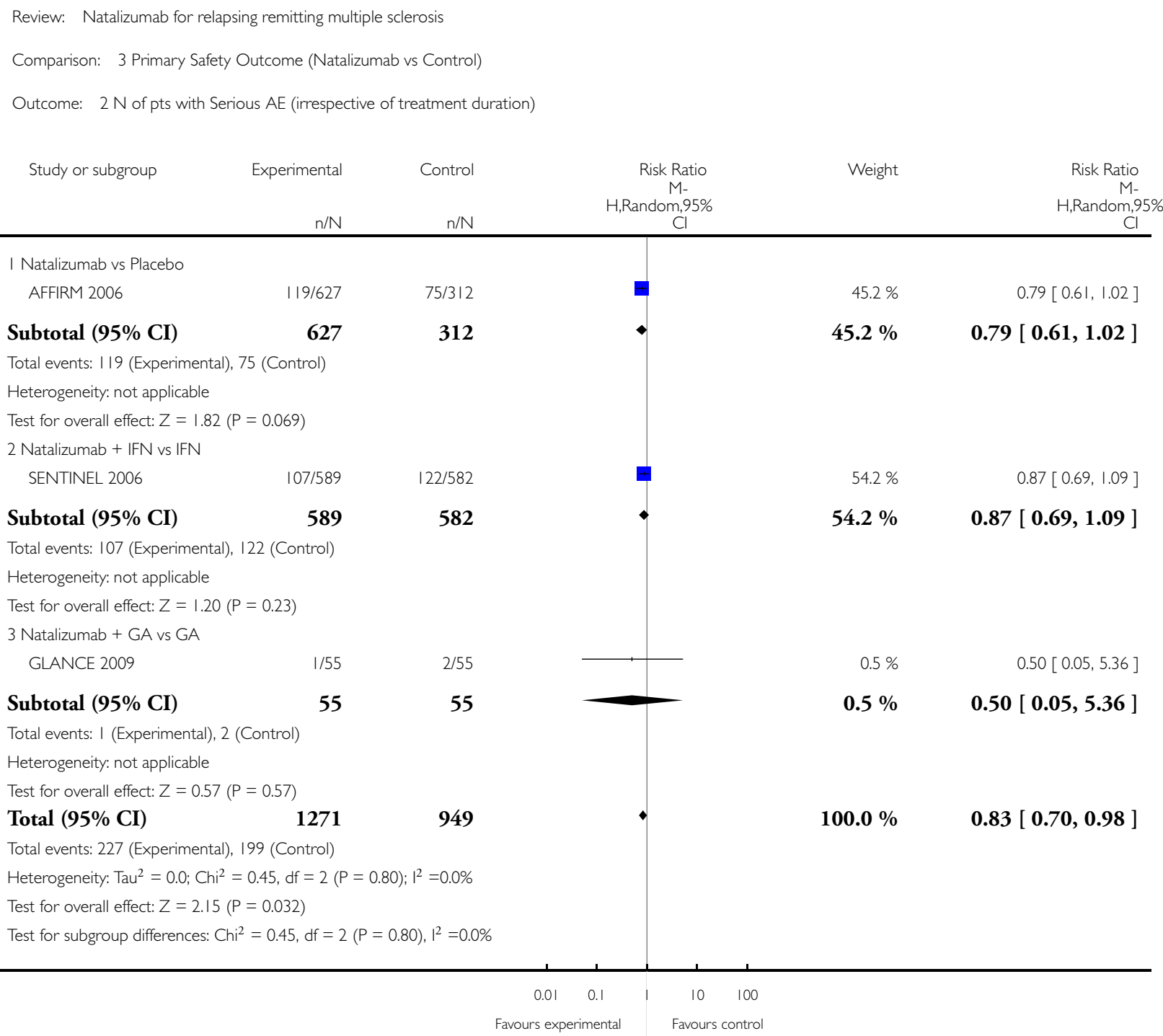




\section{Analysis 3.3. Comparison 3 Primary Safety Outcome (Natalizumab vs Control), Outcome $3 \mathbf{N}$ of pts with serious AE (irrespective of treatment duration - MS relapses excluded).}

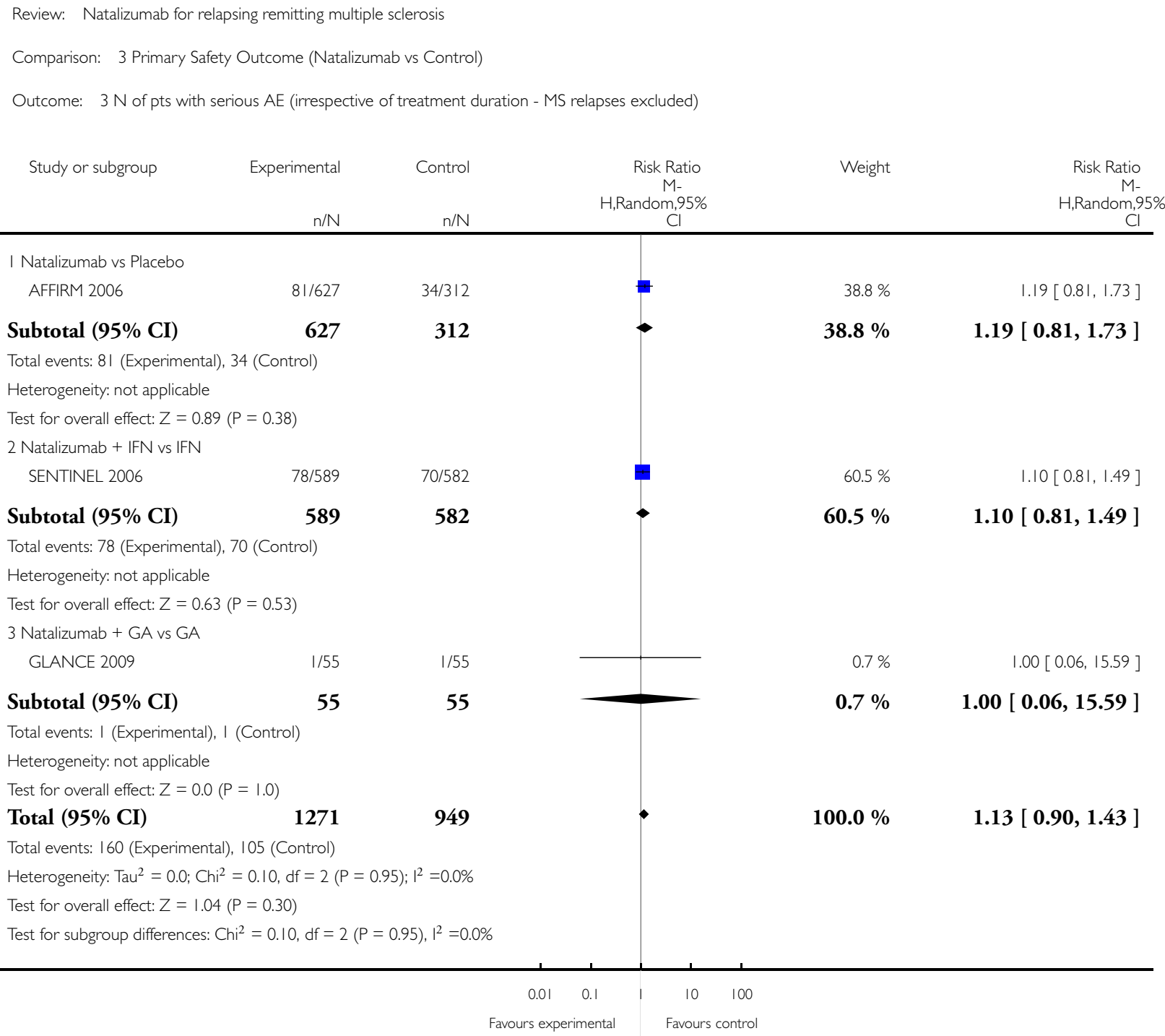




\section{Analysis 4.I. Comparison 4 Secondary Safety Outcome (Natalizumab vs Control), Outcome I N of pts with}

at least one AE (irrespective of treatment duration).

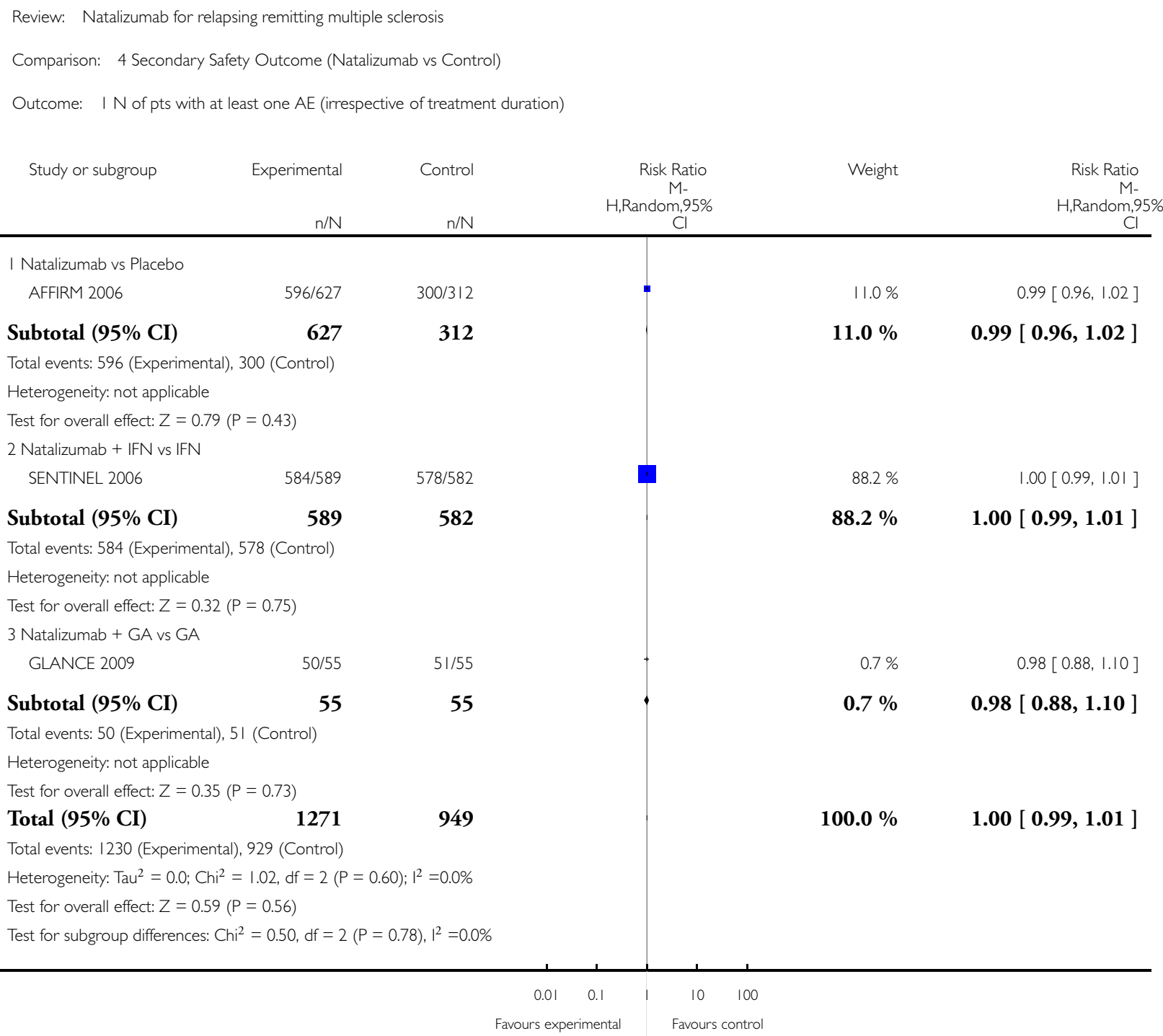


Analysis 4.2. Comparison 4 Secondary Safety Outcome (Natalizumab vs Control), Outcome 2 Treatment Discontinuation caused by AE (irrespective of treatment duration).

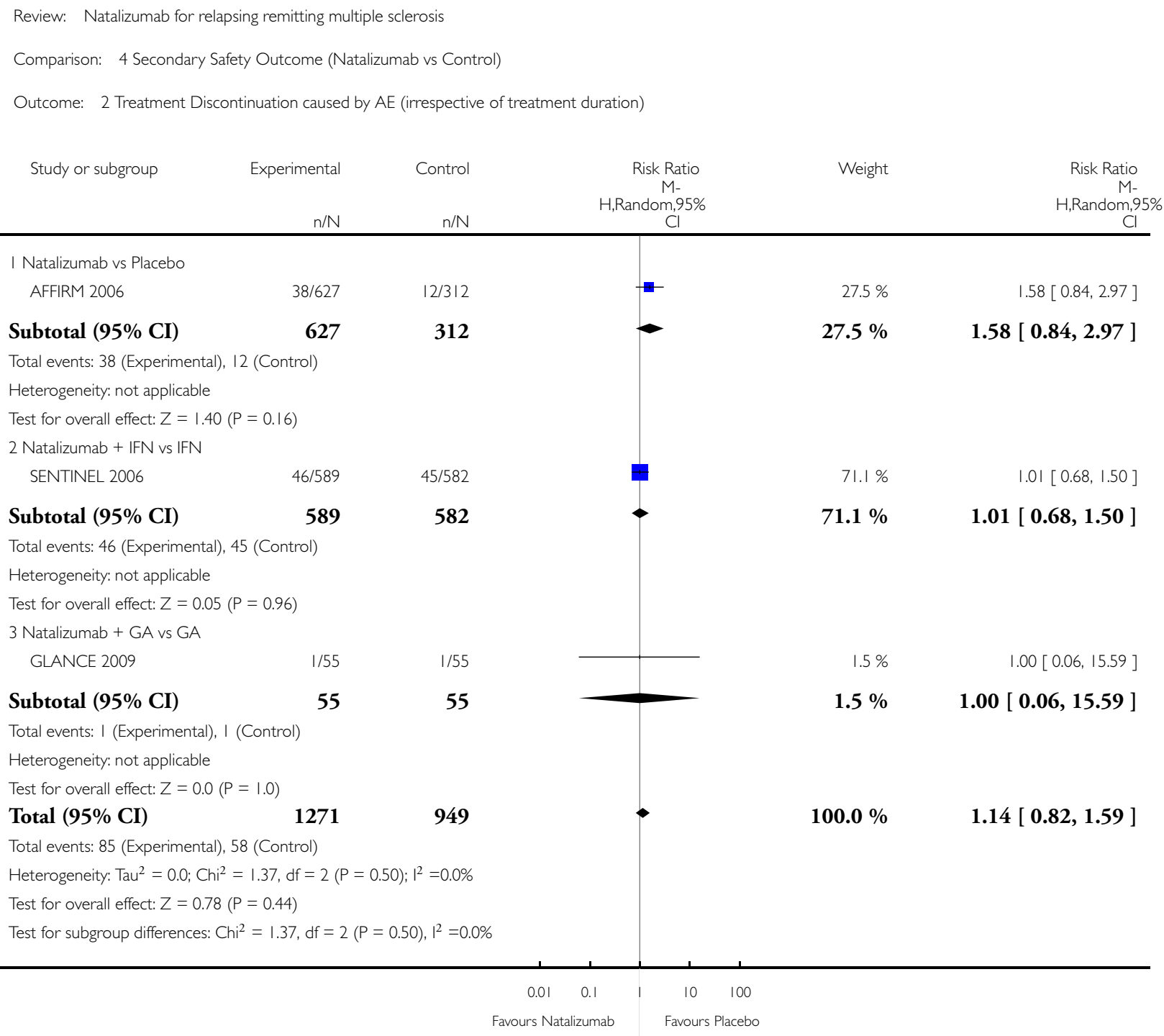




\section{Analysis 5.I. Comparison 5 Adverse Event Analysis, Outcome I Headache.}

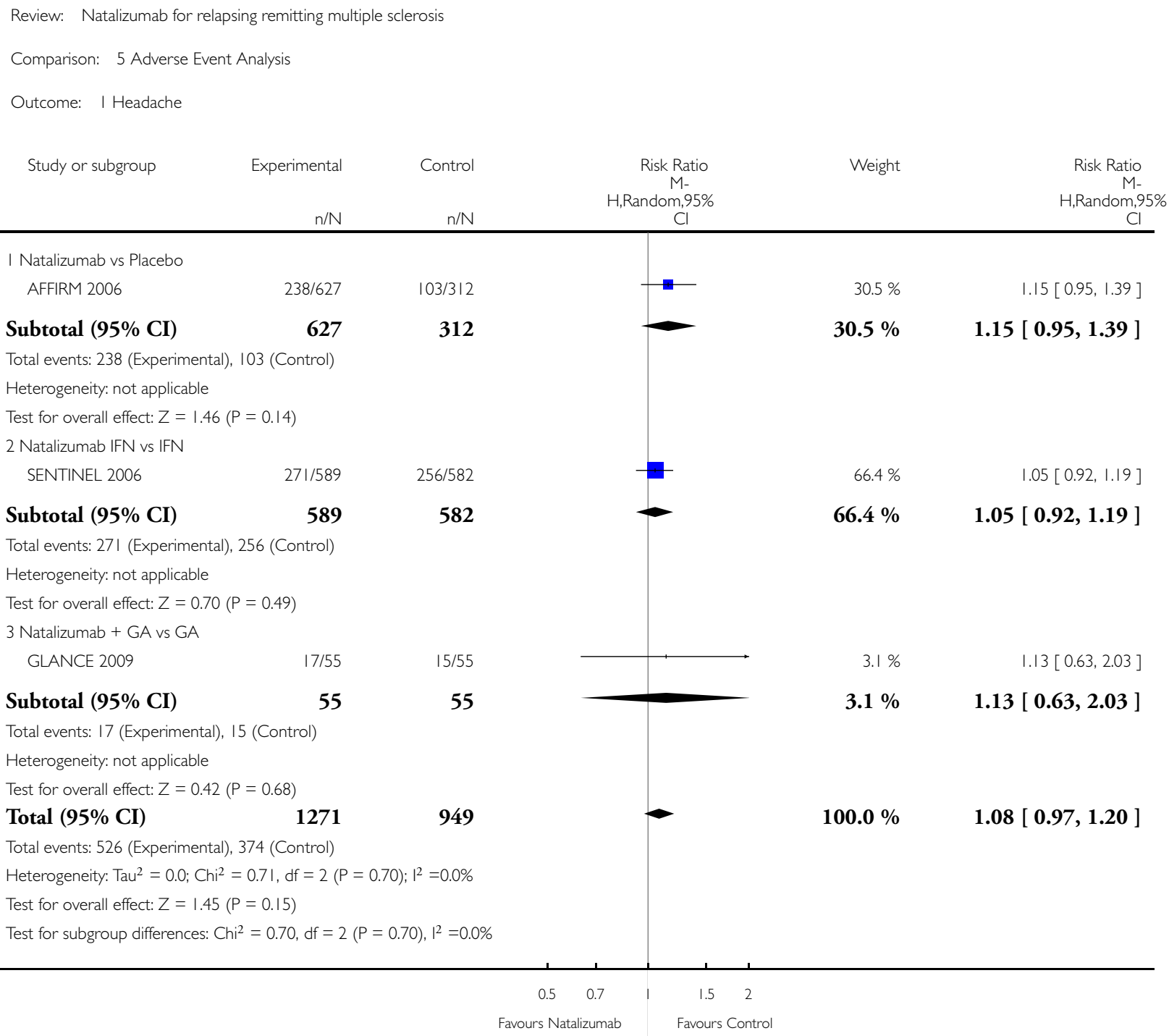




\section{Analysis 5.2. Comparison 5 Adverse Event Analysis, Outcome 2 Pain in arms or legs - Arthralgia.}

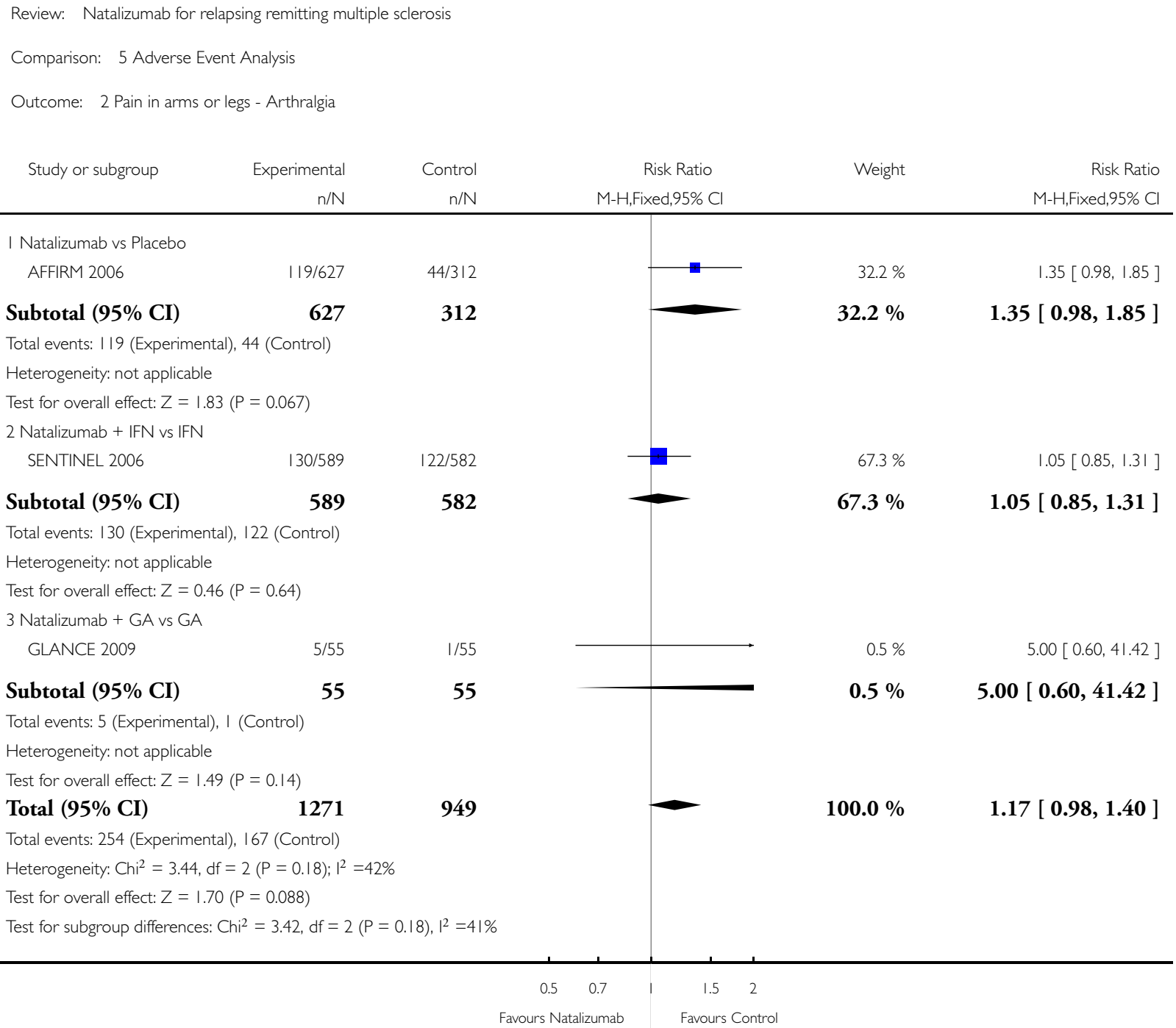




\section{Analysis 5.3. Comparison 5 Adverse Event Analysis, Outcome 3 Depression.}

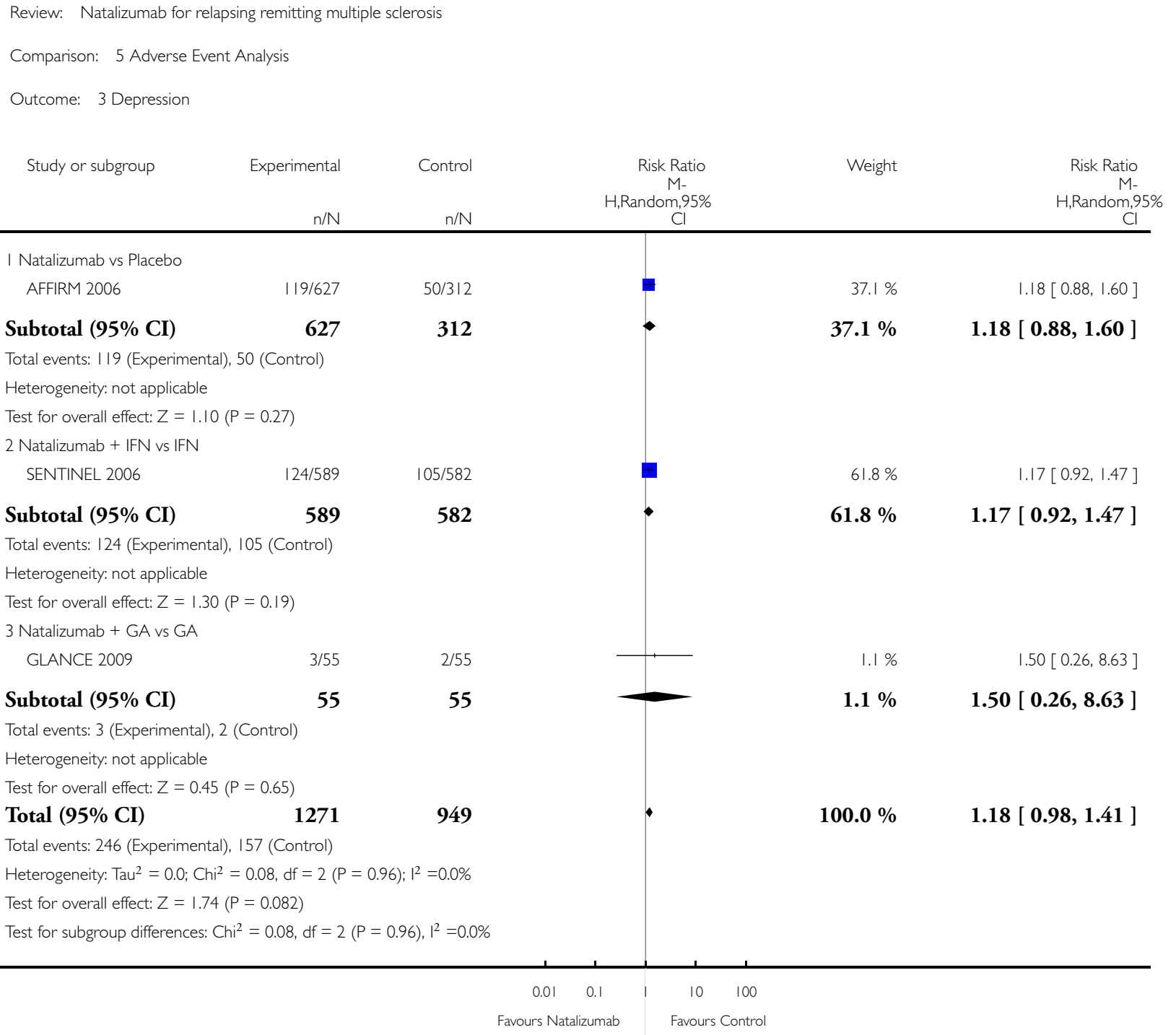




\section{Analysis 5.4. Comparison 5 Adverse Event Analysis, Outcome 4 Anxiety.}

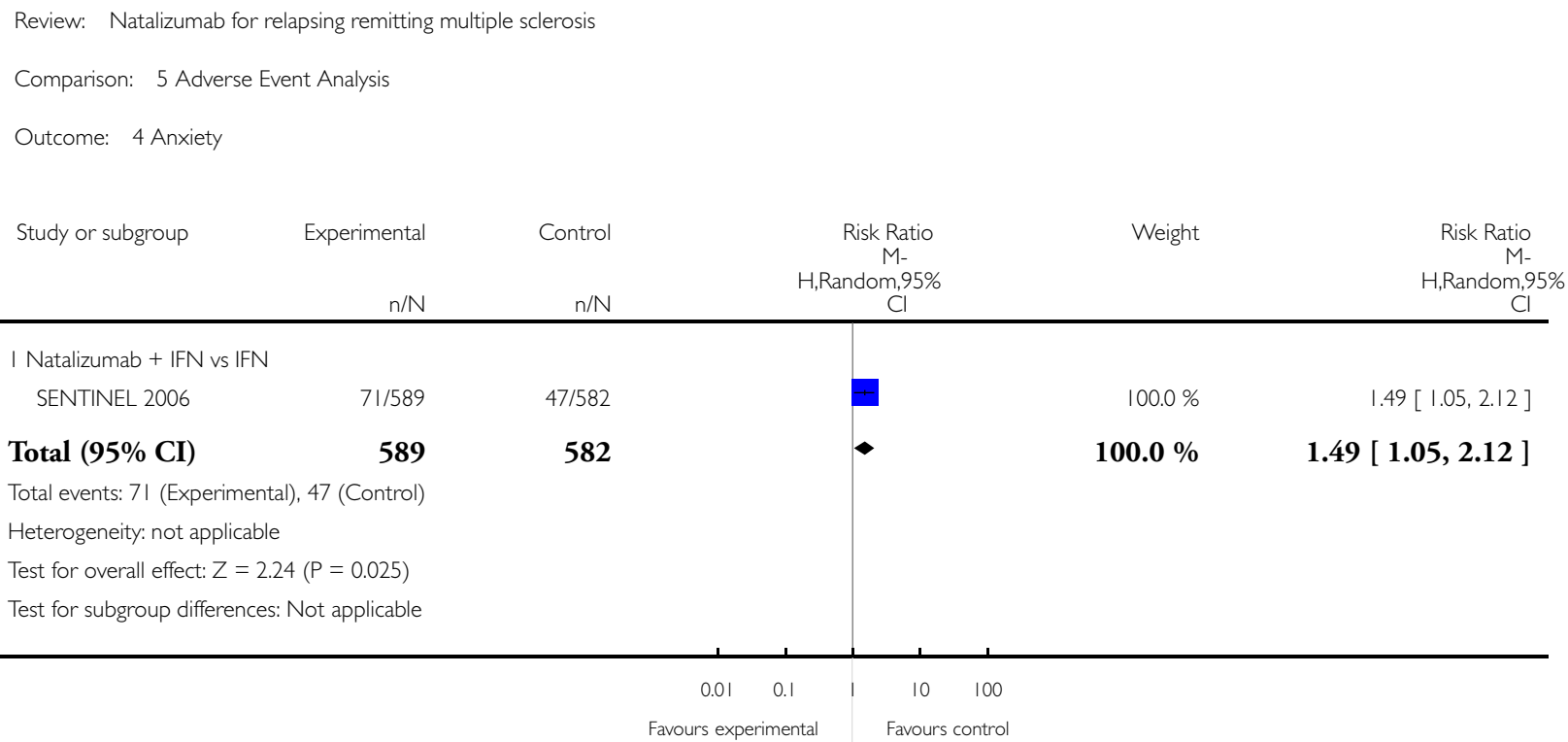

\section{Analysis 5.5. Comparison 5 Adverse Event Analysis, Outcome 5 Insomnia.}

Review: Natalizumab for relapsing remitting multiple sclerosis

Comparison: 5 Adverse Event Analysis

Outcome: 5 Insomnia

\begin{tabular}{|c|c|c|c|c|c|}
\hline Study or subgroup & Experimental & Control & $\begin{array}{c}\text { Risk Ratio } \\
\text { M- } \\
\text { H,Random,95\% } \\
\text { Cl }\end{array}$ & Weight & $\begin{array}{c}\text { Risk Ratio } \\
\text { M- } \\
\text { H,Random,95\% } \\
\text { Cl }\end{array}$ \\
\hline I Natalizumab + IFN & & & & & \\
\hline SENTINEL 2006 & $106 / 589$ & $99 / 582$ & & $100.0 \%$ & $1.06[0.82,1.36]$ \\
\hline
\end{tabular}

Total (95\% CI)

589

582

$100.0 \%$

$1.06[0.82,1.36$ ]

Total events: 106 (Experimental), 99 (Control)

Heterogeneity: not applicable

Test for overall effect: $Z=0.44(P=0.66)$

Test for subgroup differences: Not applicable

\section{$\begin{array}{lllll}0.01 & 0.1 & 1 & 10 & 100\end{array}$ \\ Favours Natalizumab Favours Control}




\section{Analysis 5.6. Comparison 5 Adverse Event Analysis, Outcome 6 Influenza Like Illness.}

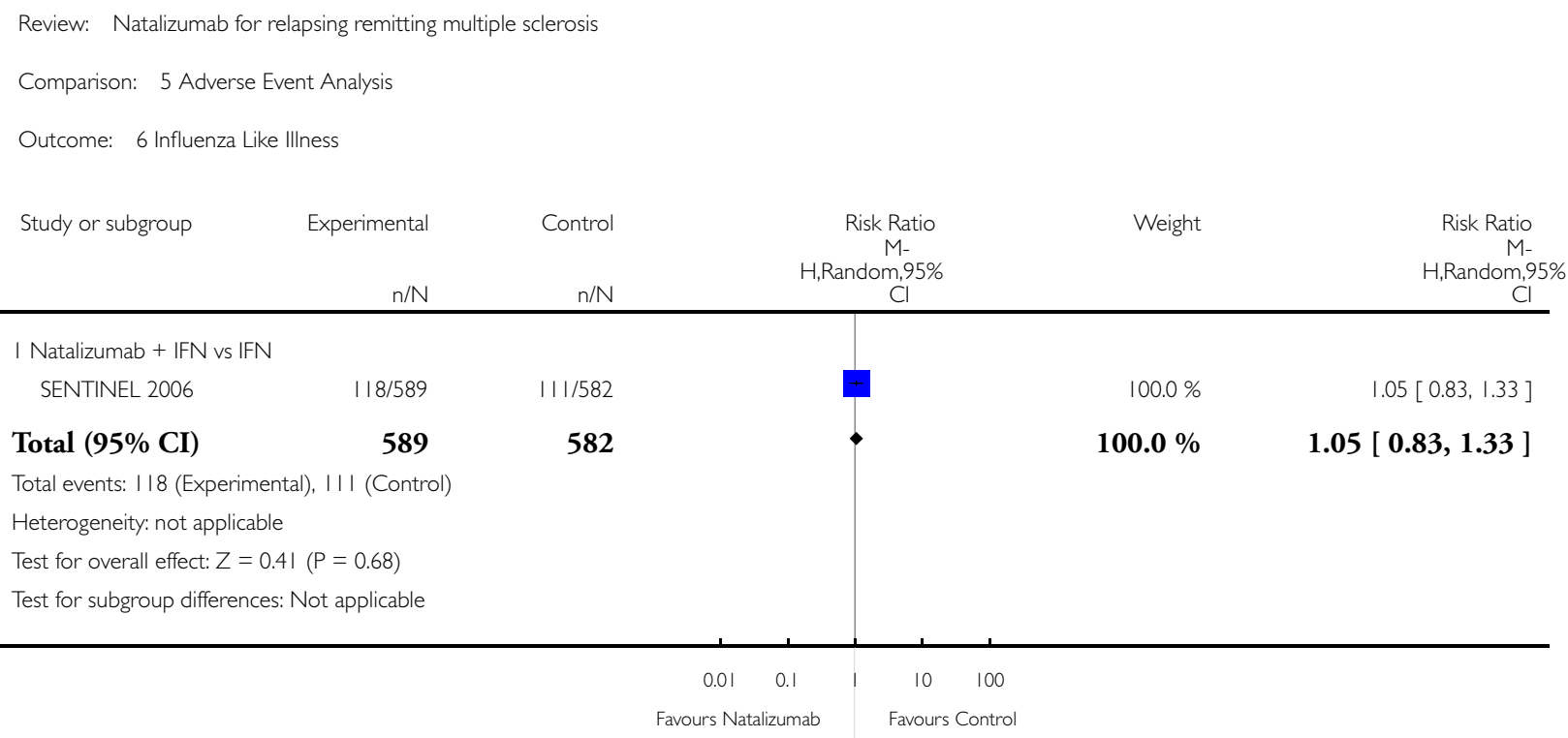




\section{Analysis 5.7. Comparison 5 Adverse Event Analysis, Outcome 7 Nasopharyngitis.}

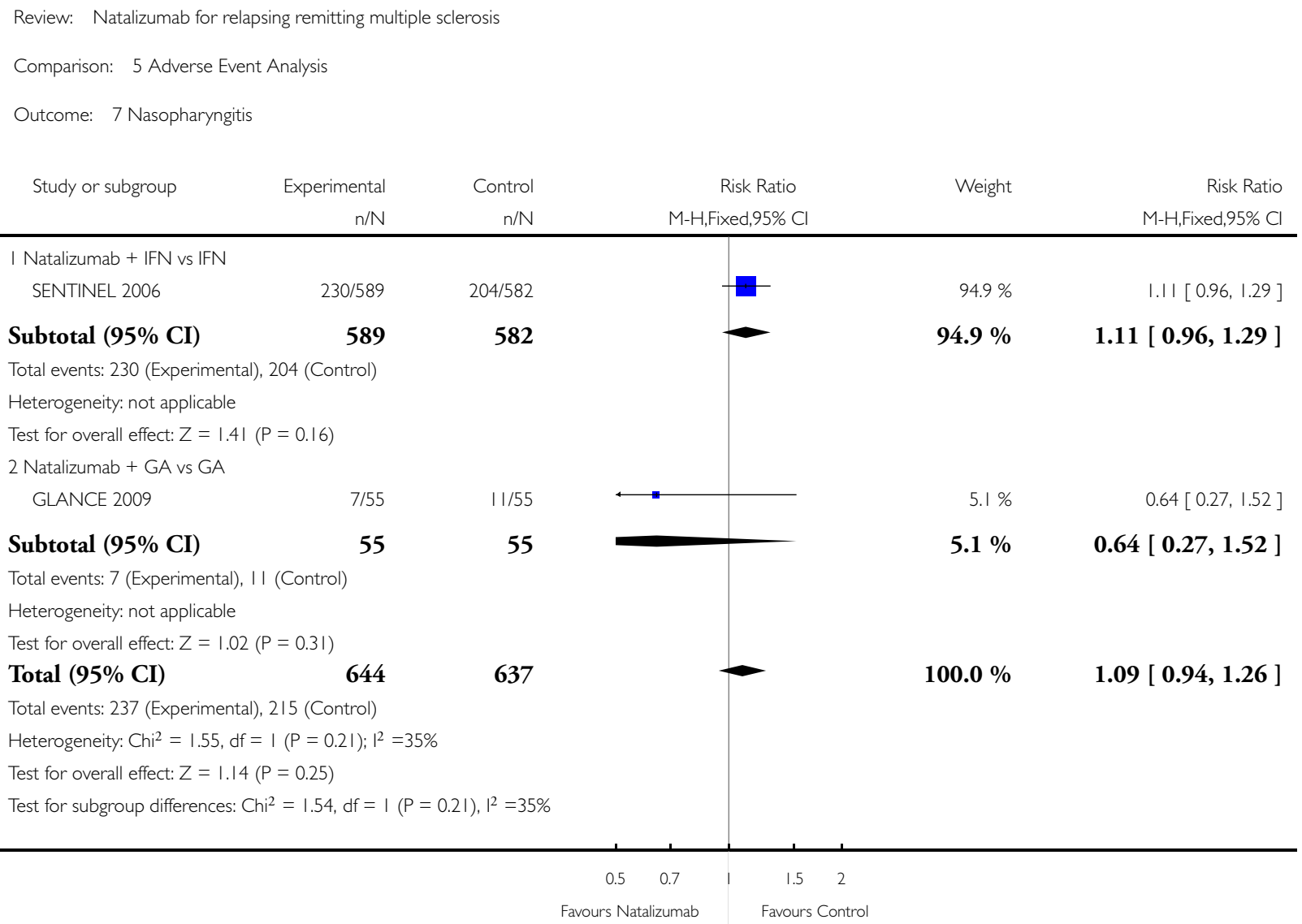




\section{Analysis 5.8. Comparison 5 Adverse Event Analysis, Outcome 8 Pharyngitis.}

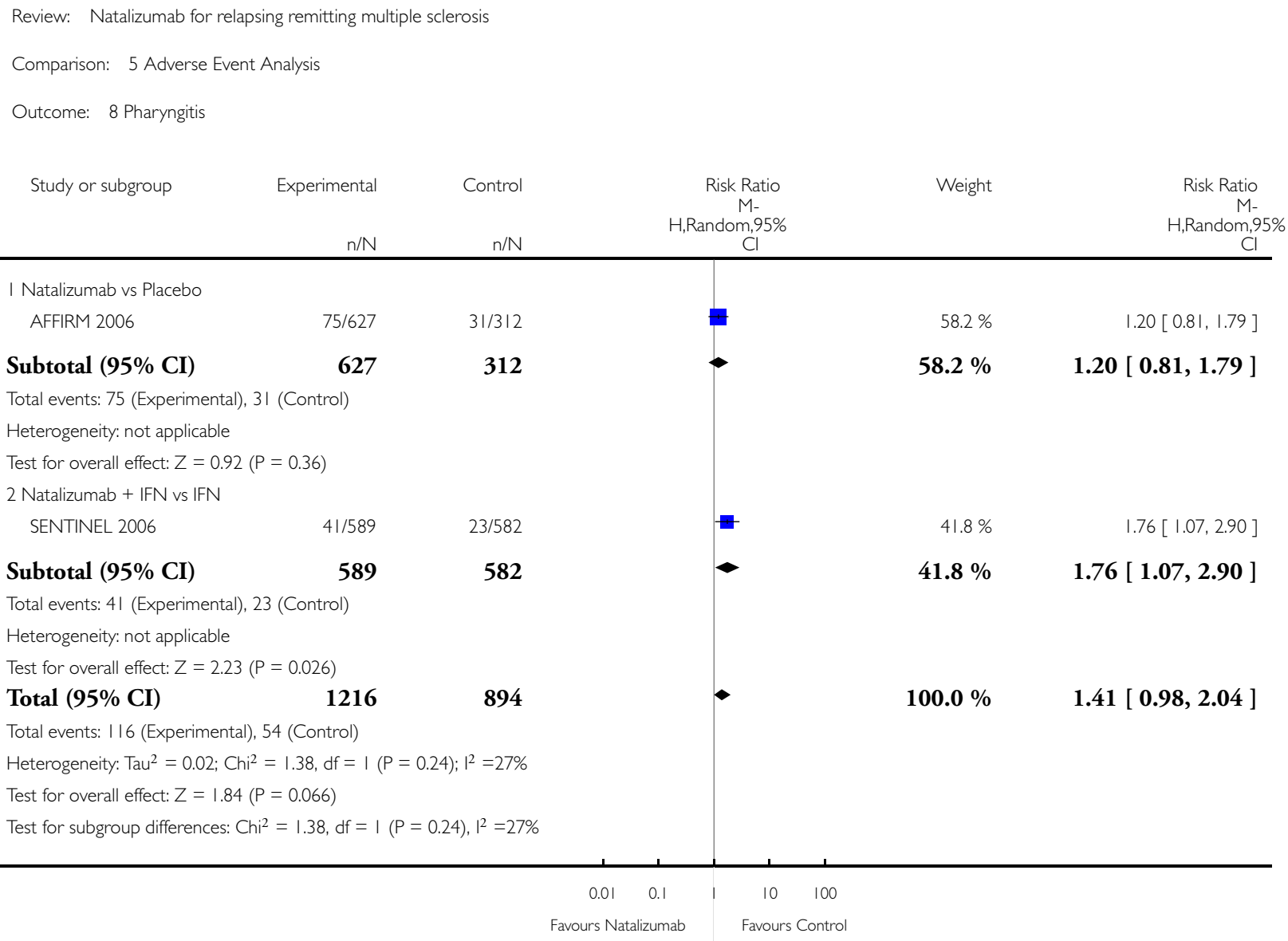




\section{Analysis 5.9. Comparison 5 Adverse Event Analysis, Outcome 9 Sinusitis.}

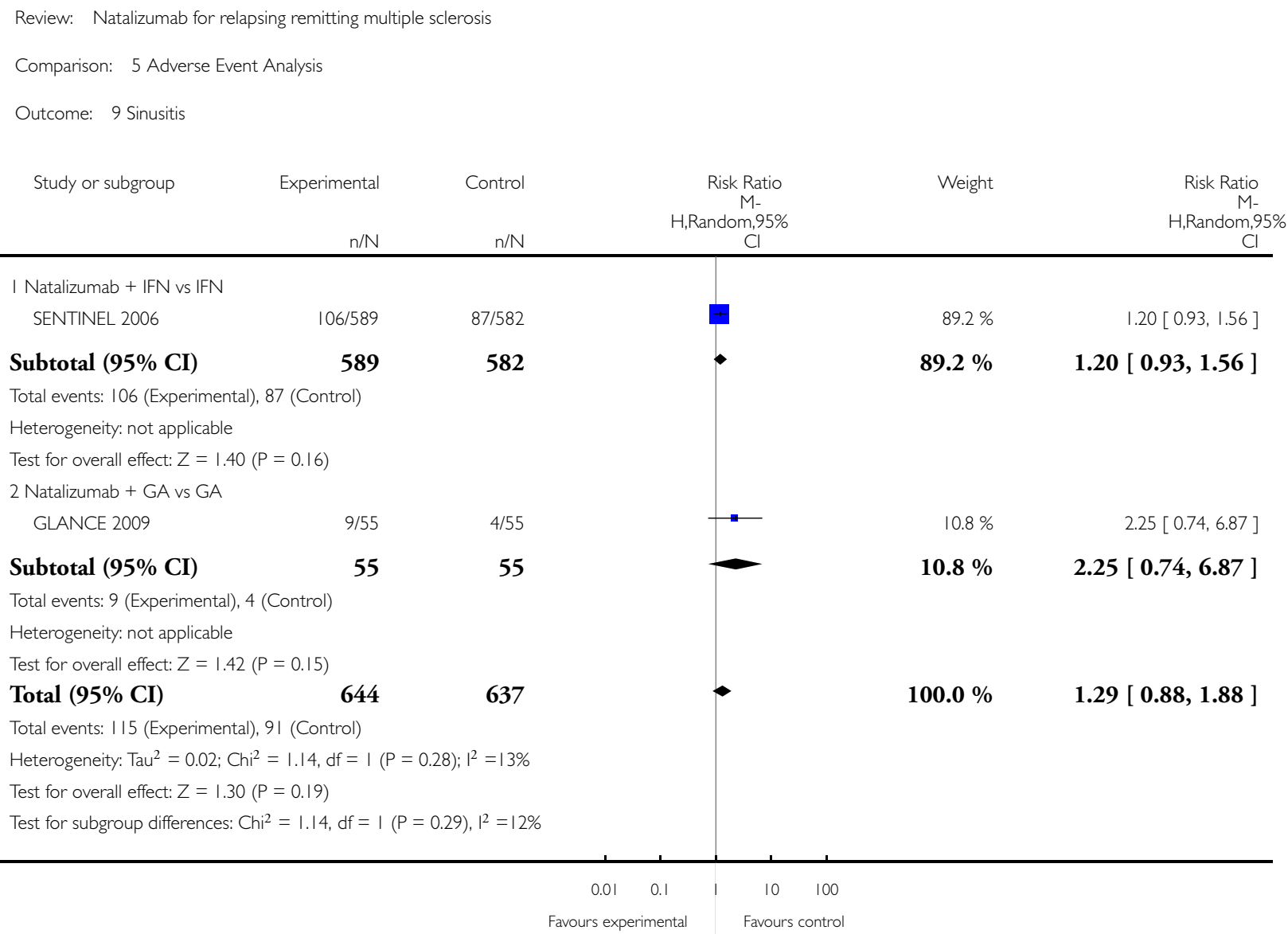




\section{Analysis 5.10. Comparison 5 Adverse Event Analysis, Outcome 10 Sinus Congestion.}

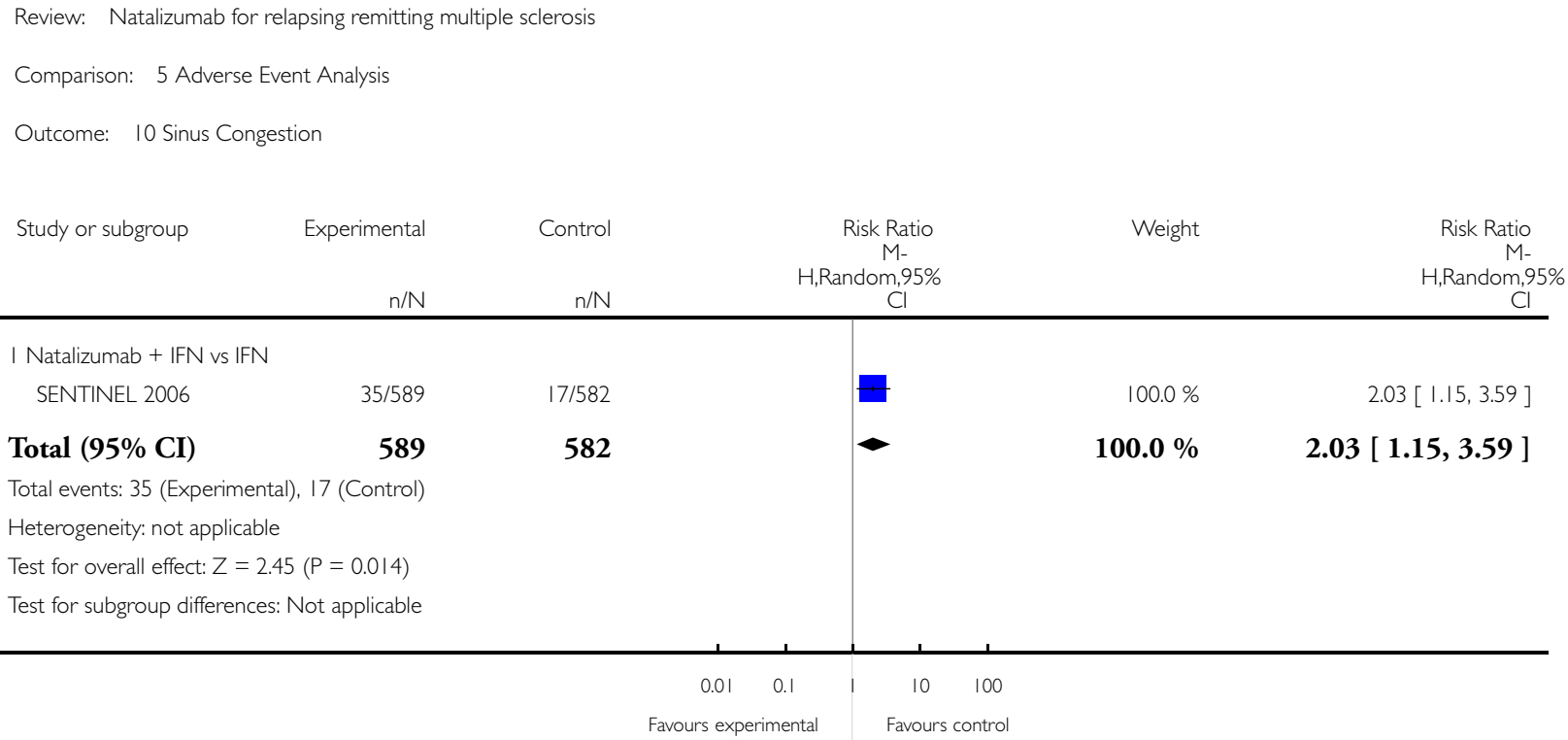

\section{Analysis 5.I I. Comparison 5 Adverse Event Analysis, Outcome I I Sinus Headache.}

Review: Natalizumab for relapsing remitting multiple sclerosis

Comparison: 5 Adverse Event Analysis

Outcome: II Sinus Headache

\begin{tabular}{|c|c|c|c|c|c|}
\hline Study or subgroup & Experimental & Control & $\begin{array}{c}\text { Risk Ratio } \\
\text { M- } \\
\text { H,Random,95\% } \\
\text { Cl }\end{array}$ & Weight & $\begin{array}{c}\text { Risk Ratio } \\
\text { M- } \\
\text { H,Random,95\% } \\
\text { Cl }\end{array}$ \\
\hline \multicolumn{6}{|c|}{ I Natalizumab + IFN vs IFN } \\
\hline SENTINEL 2006 & $29 / 589$ & $17 / 582$ & & $100.0 \%$ & $1.69[0.94,3.03]$ \\
\hline
\end{tabular}

Total (95\% CI)

589

582

$100.0 \%$

$1.69[0.94,3.03$ ]

Total events: 29 (Experimental), 17 (Control)

Heterogeneity: not applicable

Test for overall effect: $Z=1.74(P=0.082)$

Test for subgroup differences: Not applicable

\section{$\begin{array}{lllll}0.01 & 0.1 & 1 & 10 & 100\end{array}$ \\ Favours experimental \\ Favours control}




\section{Analysis 5.12. Comparison 5 Adverse Event Analysis, Outcome 12 Upper Respiratory Infection.}

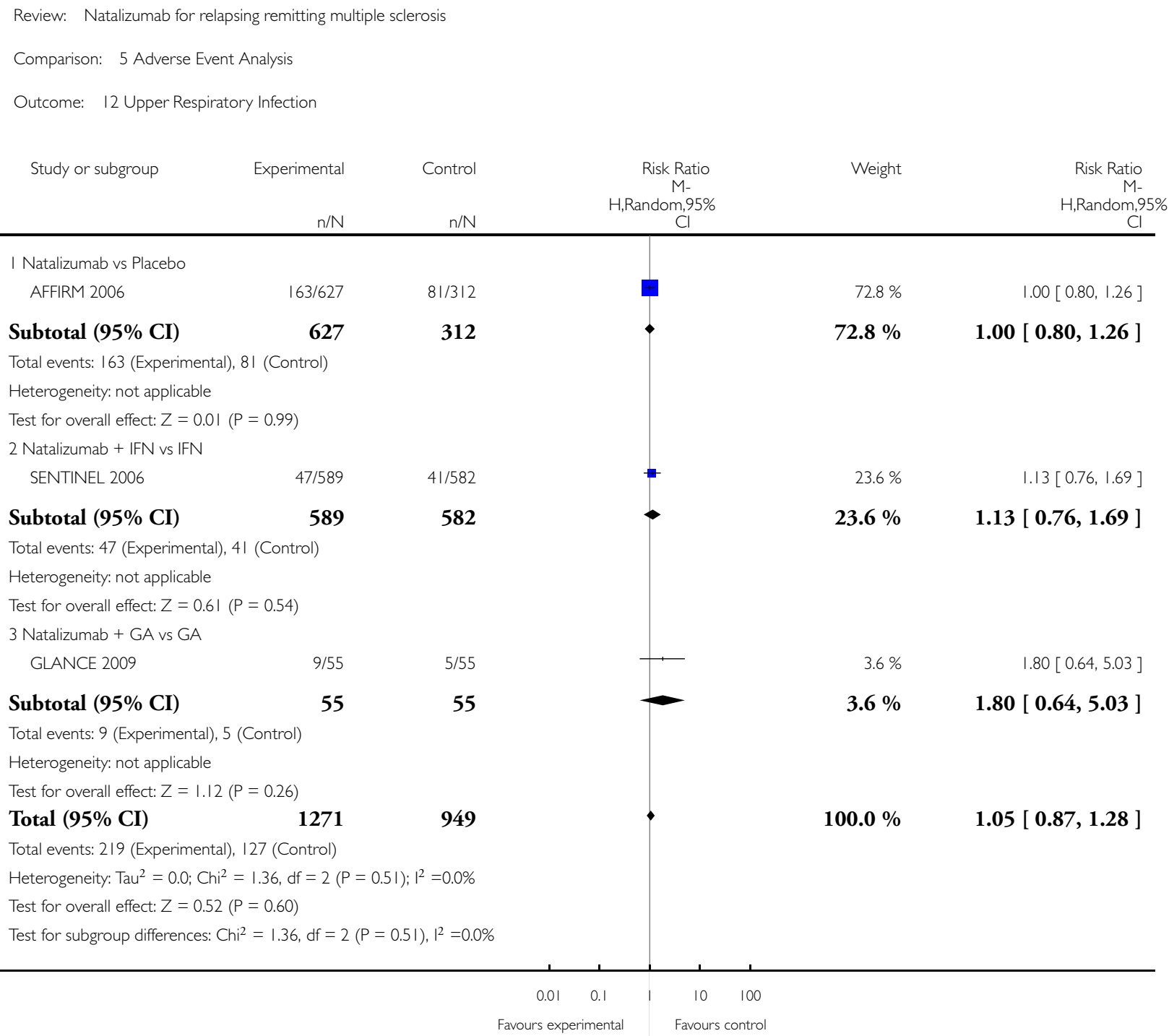




\section{Analysis 5.13. Comparison 5 Adverse Event Analysis, Outcome 13 Influenza.}

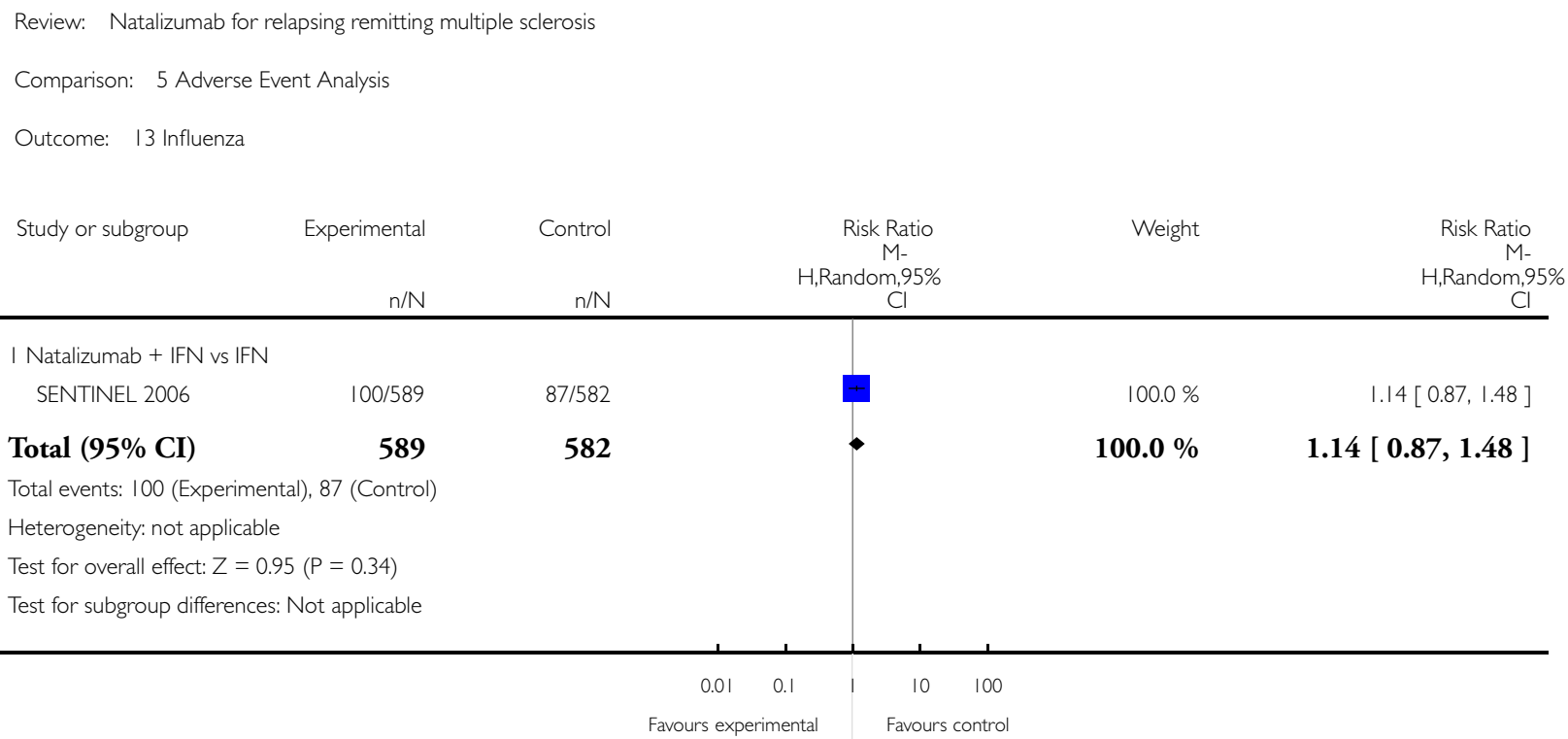

Analysis 5.14. Comparison 5 Adverse Event Analysis, Outcome 14 Cough.

Review: Natalizumab for relapsing remitting multiple sclerosis

Comparison: 5 Adverse Event Analysis

Outcome: 14 Cough

Control Risk Ratio

$M-$

H,Random, $95 \%$

$\mathrm{n} / \mathrm{N} \quad \mathrm{n} / \mathrm{N}$

$\mathrm{Cl}$

Weight

Risk Ratio

H,Random, $95 \%$

I Natalizumab + IFN vs IFN

SENTINEL 2006

$65 / 589 \quad 52 / 582$

$100.0 \%$

$1.24[0.87,1.75]$

Total (95\% CI)

589

582

$+$

$100.0 \%$

$1.24[0.87,1.75]$

Total events: 65 (Experimental), 52 (Control)

Heterogeneity: not applicable

Test for overall effect: $Z=1.20(P=0.23)$

Test for subgroup differences: Not applicable

$\begin{array}{ccccc}0.01 & 0.1 & 1 & 10 & 100 \\ & \text { Favours experimental } & & \text { Favours control }\end{array}$

Copyright $\odot 201$ I The Cochrane Collaboration. Published by John Wiley \& Sons, Ltd. 


\section{Analysis 5.15. Comparison 5 Adverse Event Analysis, Outcome 15 Diarrhea.}

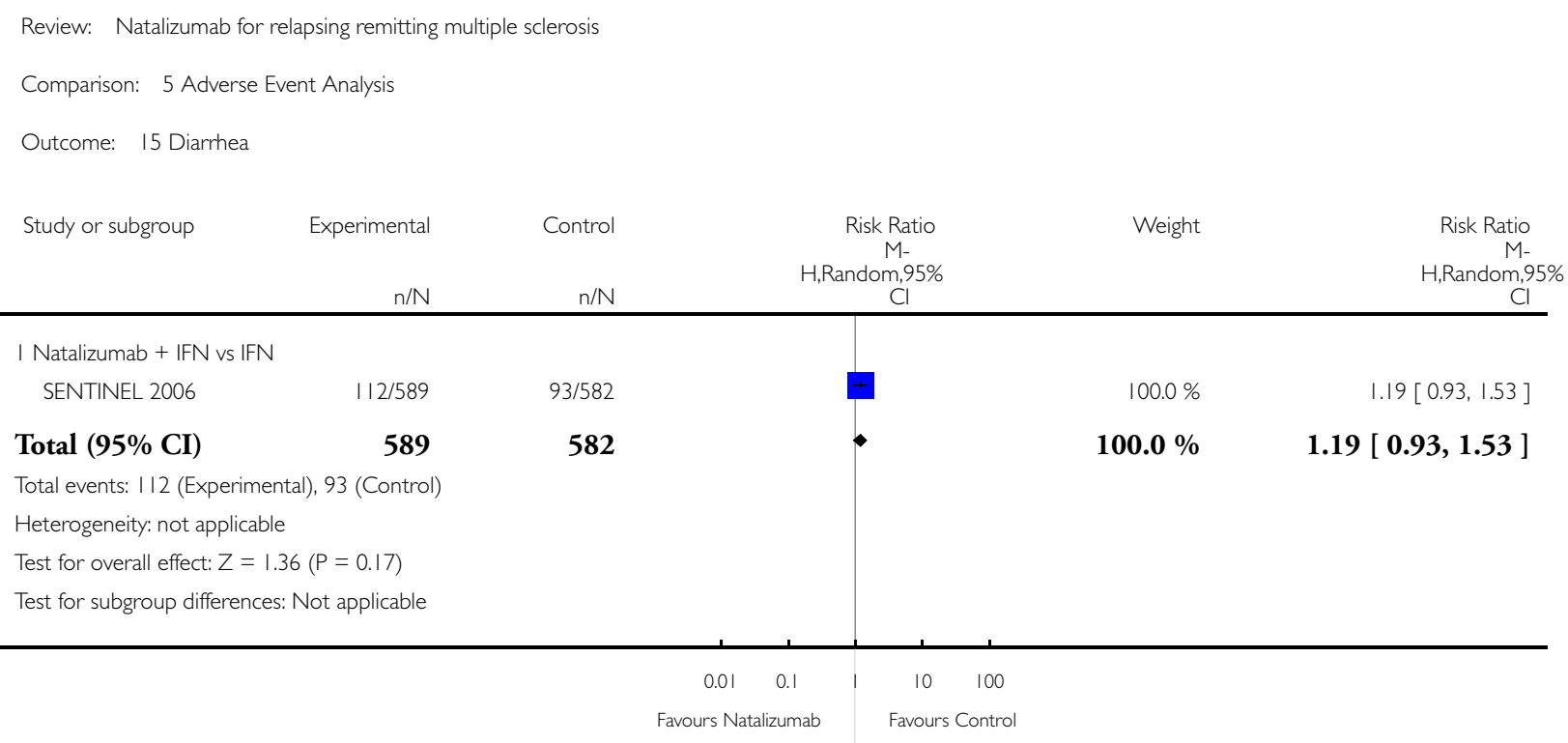




\section{Analysis 5.16. Comparison 5 Adverse Event Analysis, Outcome 16 Nausea.}

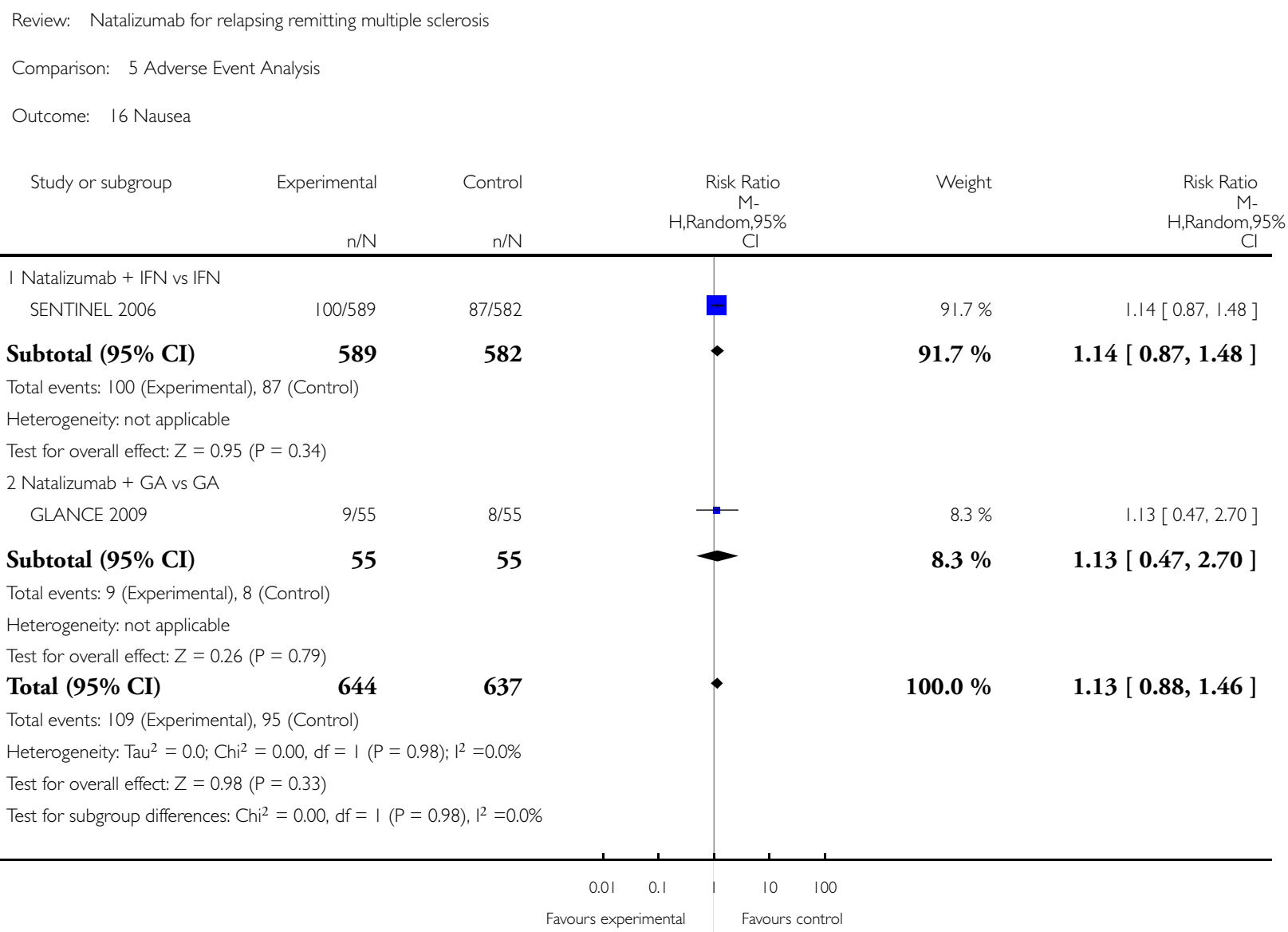




\section{Analysis 5.17. Comparison 5 Adverse Event Analysis, Outcome 17 Vomiting.}

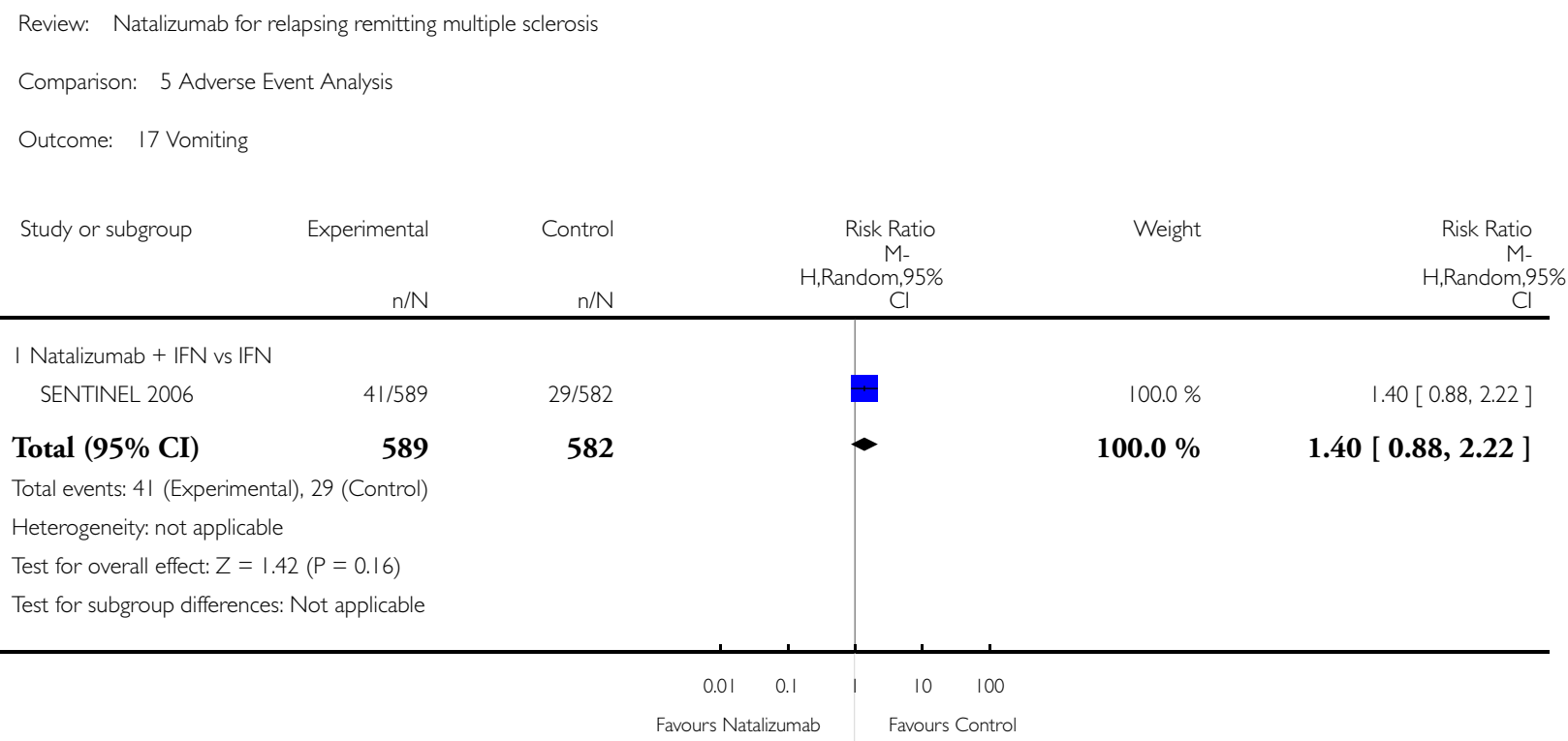




\section{Analysis 5.18. Comparison 5 Adverse Event Analysis, Outcome 18 Abdominal Pain or Discomfort.}

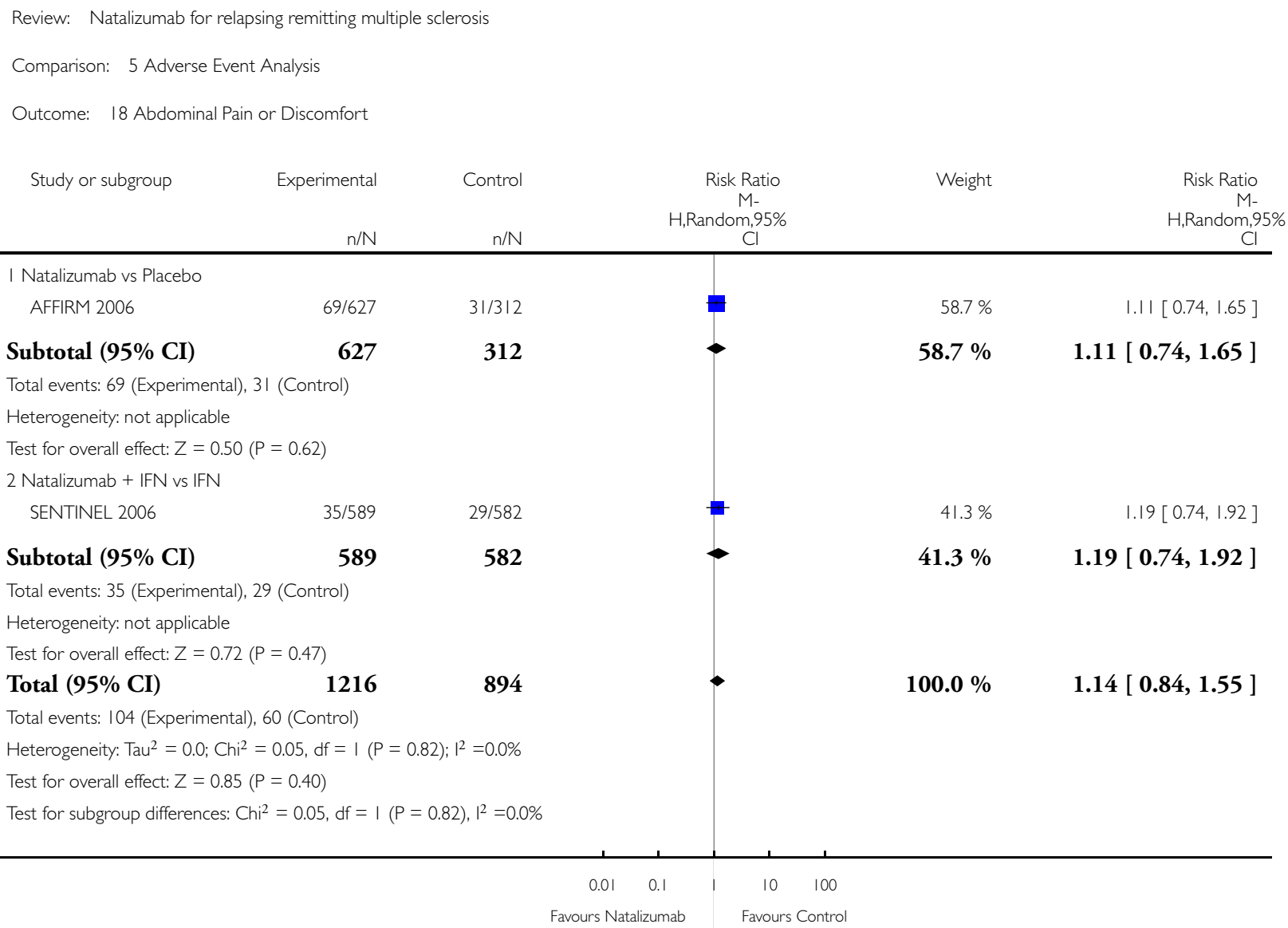




\section{Analysis 5.19. Comparison 5 Adverse Event Analysis, Outcome 19 Muscle Cramp.}

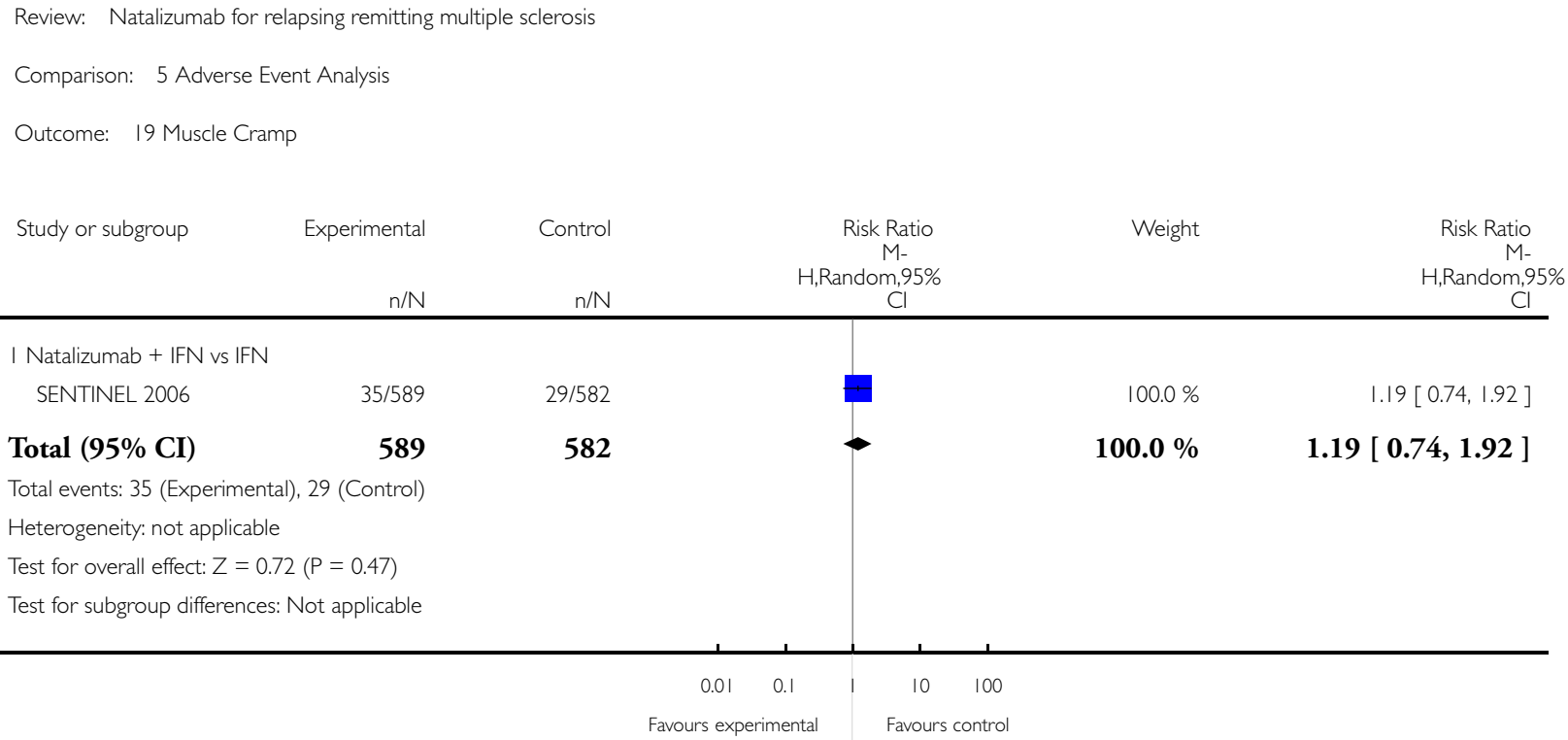

Analysis 5.20. Comparison 5 Adverse Event Analysis, Outcome 20 Myalgia.

Review: Natalizumab for relapsing remitting multiple sclerosis

Comparison: 5 Adverse Event Analysis

Outcome: 20 Myalgia

\begin{tabular}{|c|c|c|c|c|c|}
\hline Study or subgroup & Experimental & Control & $\begin{array}{c}\text { Risk Ratio } \\
\text { M- } \\
\text { H,Random,95\% } \\
\text { Cl }\end{array}$ & Weight & $\begin{array}{c}\text { Risk Ratio } \\
\text { M- } \\
\text { H,Random,95\% } \\
\text { Cl }\end{array}$ \\
\hline \multicolumn{6}{|c|}{ I Natalizumab + IFN vs IFN } \\
\hline SENTINEL 2006 & $77 / 589$ & $58 / 582$ & & $100.0 \%$ & $1.31[0.95,1.81]$ \\
\hline
\end{tabular}

Total (95\% CI)

589

582

$100.0 \%$

$1.31[0.95,1.81]$

Total events: 77 (Experimental), 58 (Control)

Heterogeneity: not applicable

Test for overall effect: $Z=1.66(P=0.097)$

Test for subgroup differences: Not applicable

$\begin{array}{cccccc}0.01 & 0.1 & 1 & 10 & 100 \\ & \text { Favours experimental } & & \text { Favours control }\end{array}$ 


\section{Analysis 5.21. Comparison 5 Adverse Event Analysis, Outcome 2 I Seasonal Allergy.}

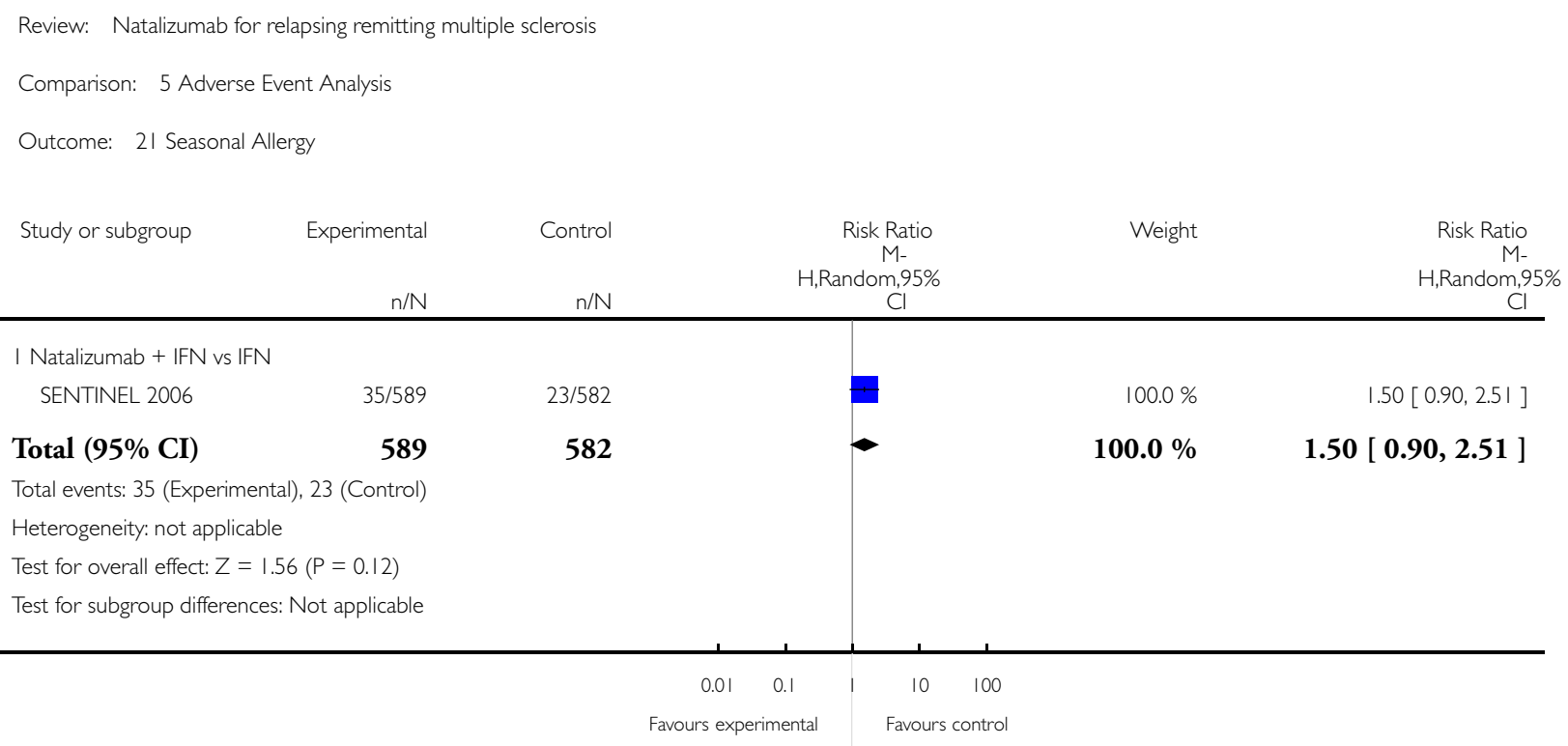




\section{Analysis 5.22. Comparison 5 Adverse Event Analysis, Outcome 22 Peripheral Edema.}

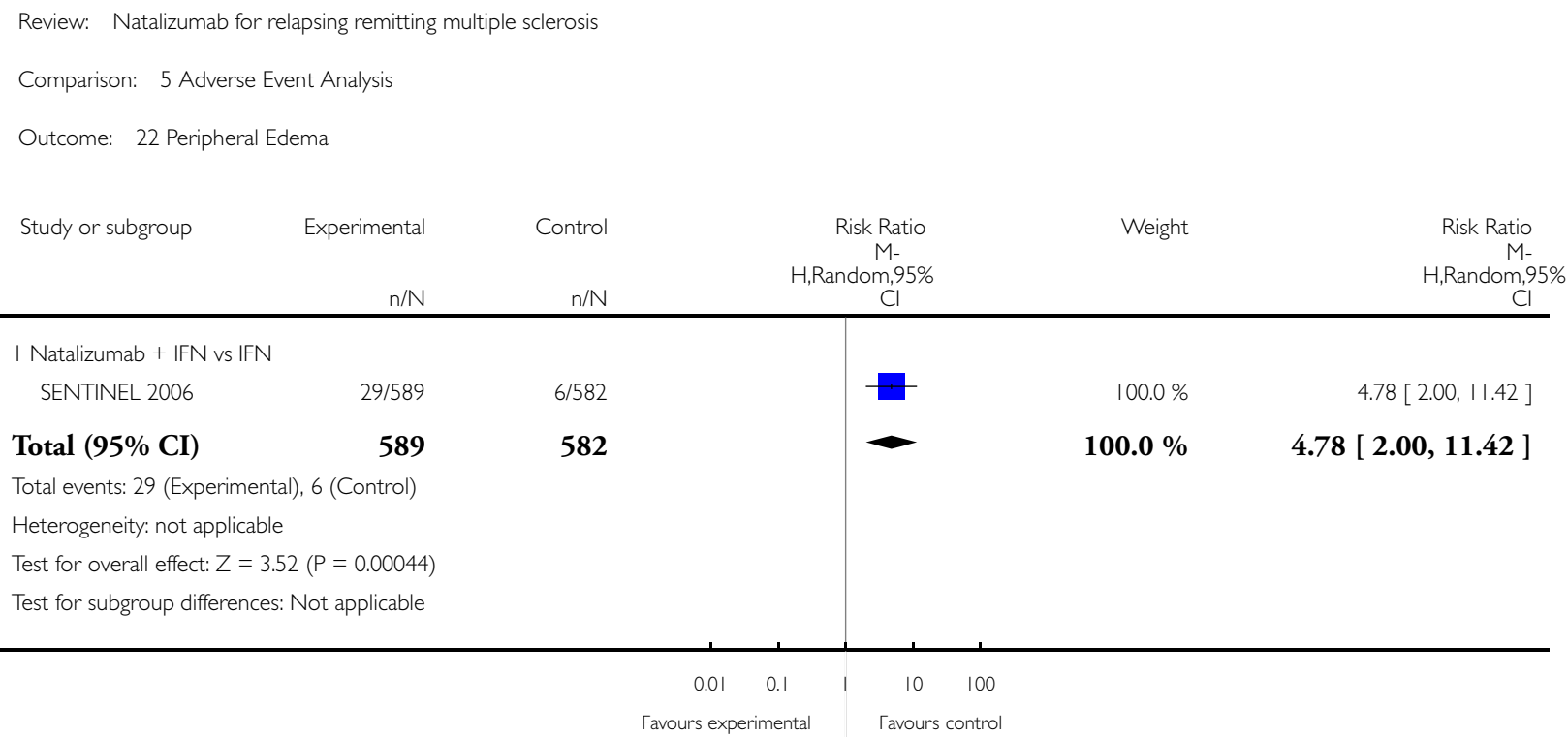




\section{Analysis 5.23. Comparison 5 Adverse Event Analysis, Outcome 23 Tremor.}

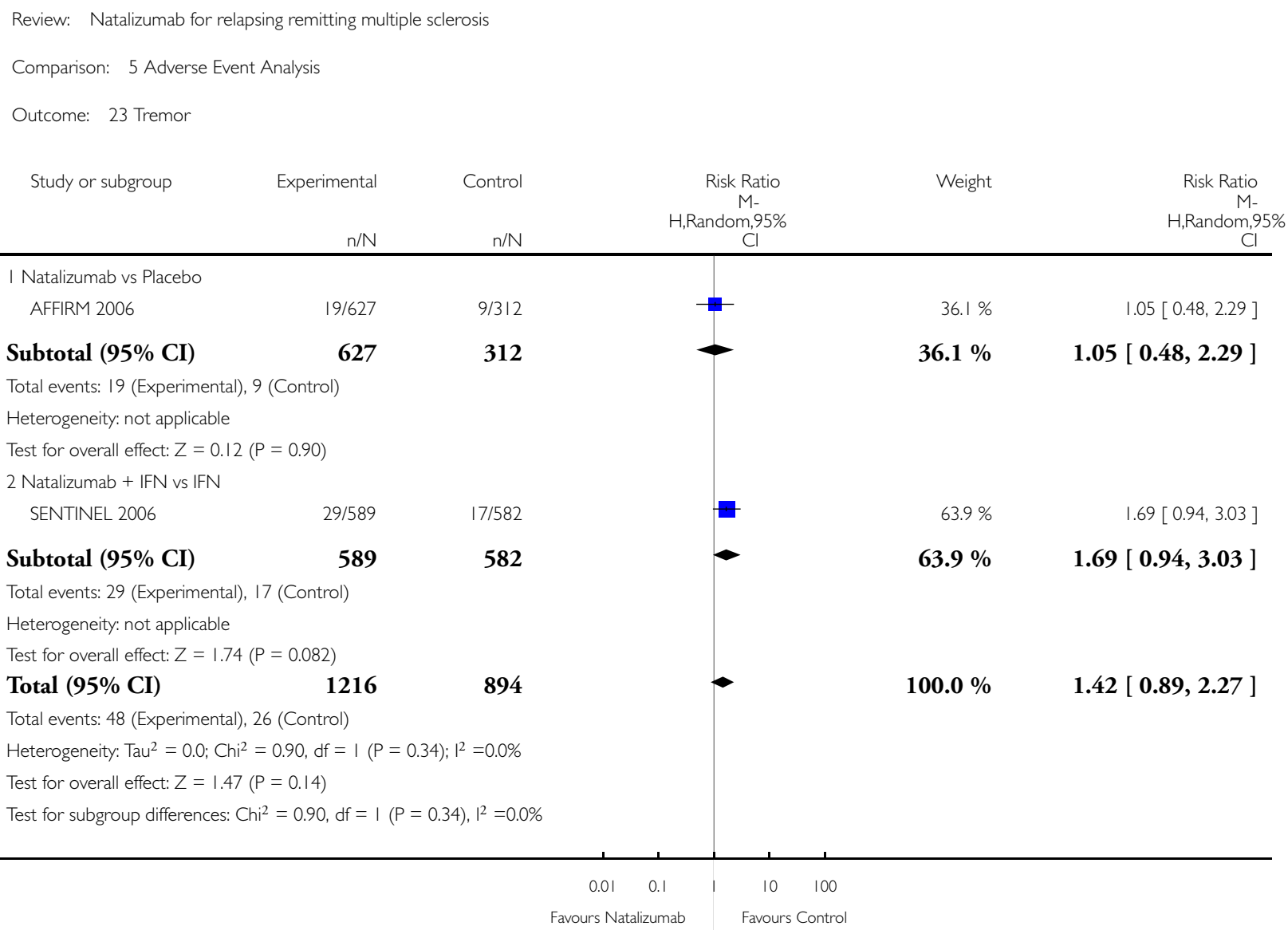




\section{Analysis 5.24. Comparison 5 Adverse Event Analysis, Outcome 24 Flushing.}

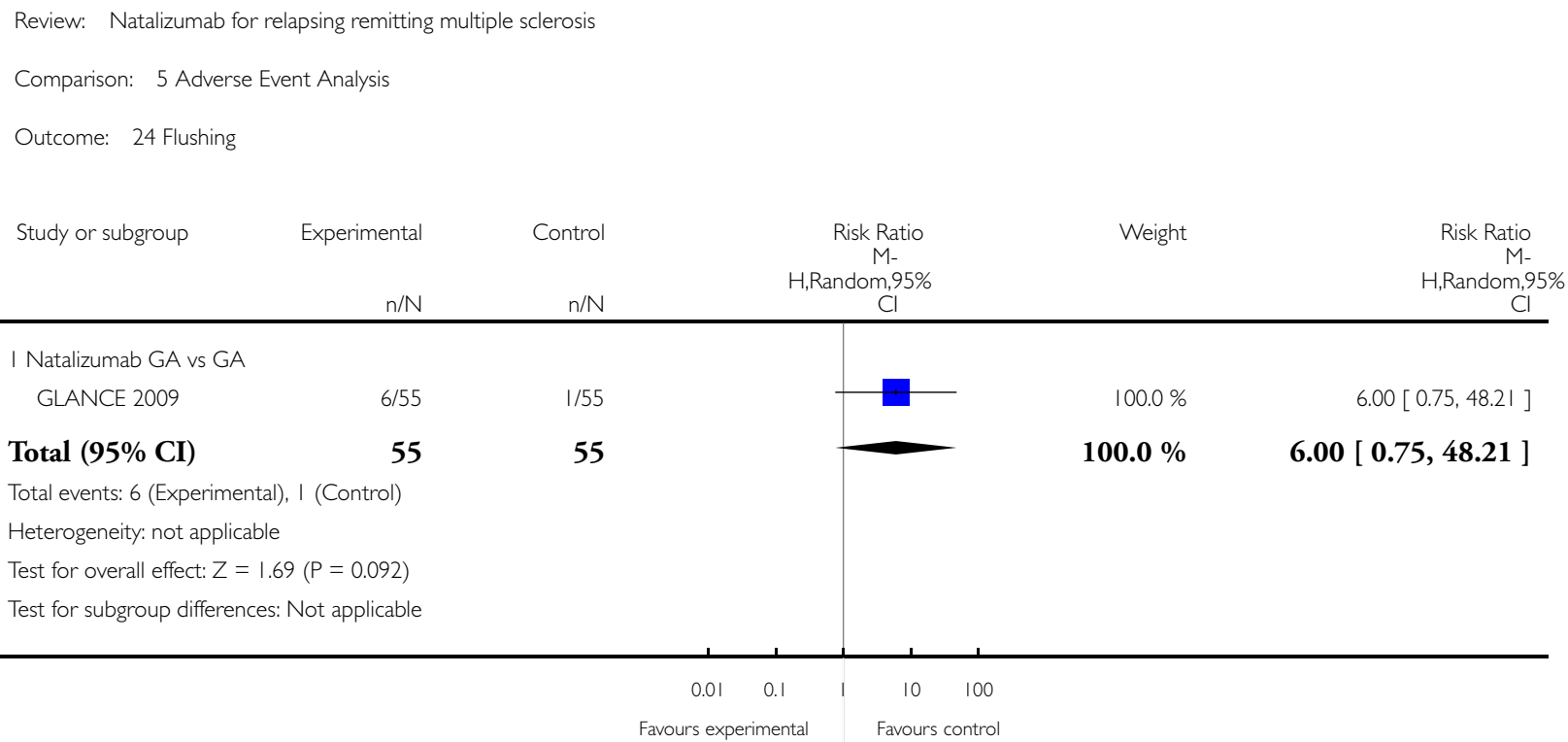

\section{Analysis 5.25. Comparison 5 Adverse Event Analysis, Outcome 25 Fatigue - Myasthenia.}

Review: Natalizumab for relapsing remitting multiple sclerosis

Comparison: 5 Adverse Event Analysis

Outcome: 25 Fatigue - Myasthenia

\begin{tabular}{|c|c|c|c|c|c|}
\hline Study or subgroup & Experimental & Control & $\begin{array}{c}\text { Risk Ratio } \\
\text { M- } \\
\text { H,Random,95\% } \\
\text { Cl }\end{array}$ & Weight & $\begin{array}{c}\text { Risk Ratio } \\
\text { M- } \\
\text { H,Random,95\% } \\
\text { Cl }\end{array}$ \\
\hline \multicolumn{6}{|c|}{ I Natalizumab vs Placebo } \\
\hline AFFIRM 2006 & $169 / 627$ & $66 / 312$ & & $100.0 \%$ & $1.27[0.99,1.64]$ \\
\hline
\end{tabular}

Total (95\% CI)

627

312

$100.0 \%$

$1.27[0.99,1.64]$

Total events: 169 (Experimental), 66 (Control)

Heterogeneity: not applicable

Test for overall effect: $Z=1.90(P=0.057)$

Test for subgroup differences: Not applicable

\section{$\begin{array}{lllll}0.01 & 0.1 & 1 & 10 & 100\end{array}$ \\ Favours Natalizumab Favours Control}




\section{Analysis 5.26. Comparison 5 Adverse Event Analysis, Outcome 26 Urinary Urgency / Frequency.}

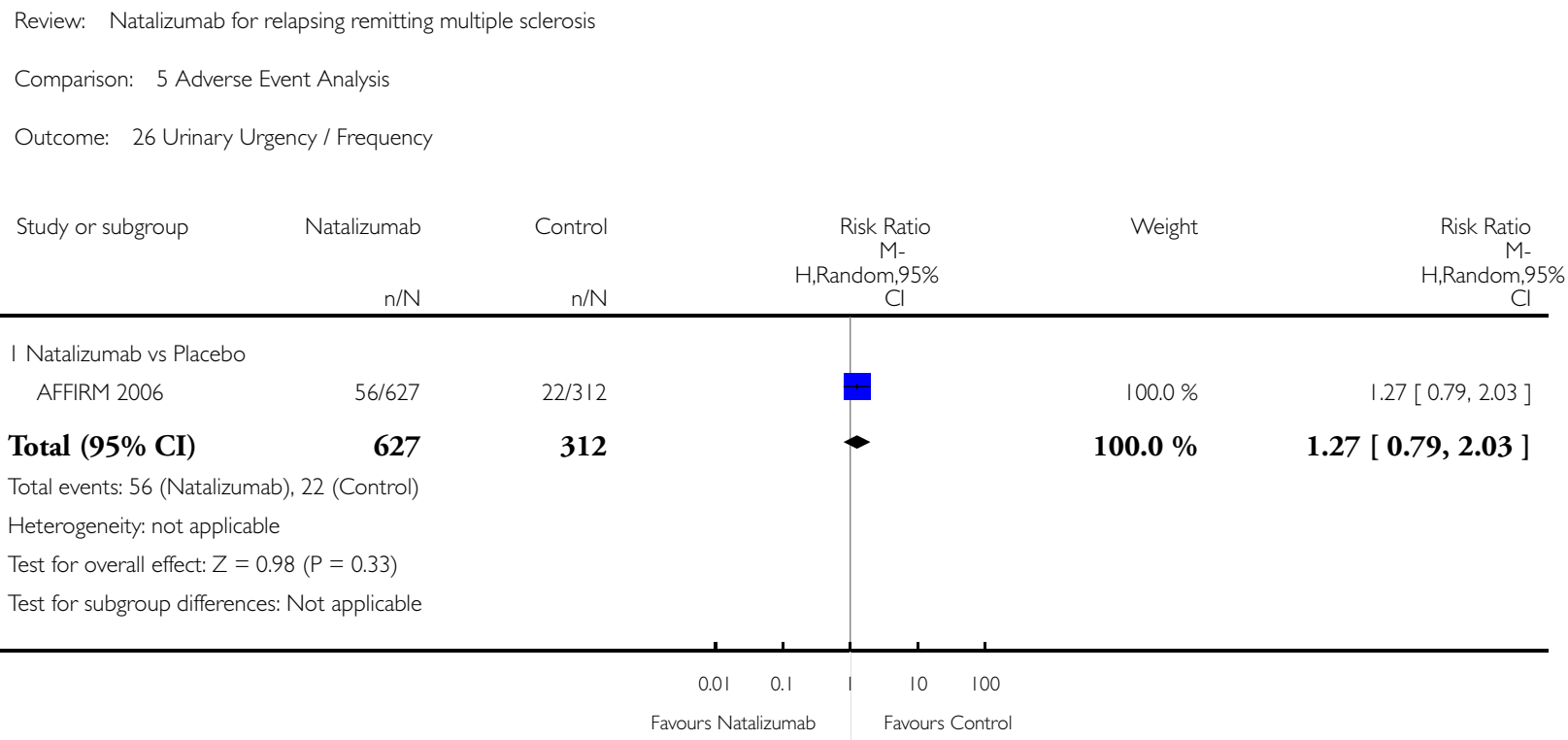




\section{Analysis 5.27. Comparison 5 Adverse Event Analysis, Outcome 27 Hypersensitivity reactions.}

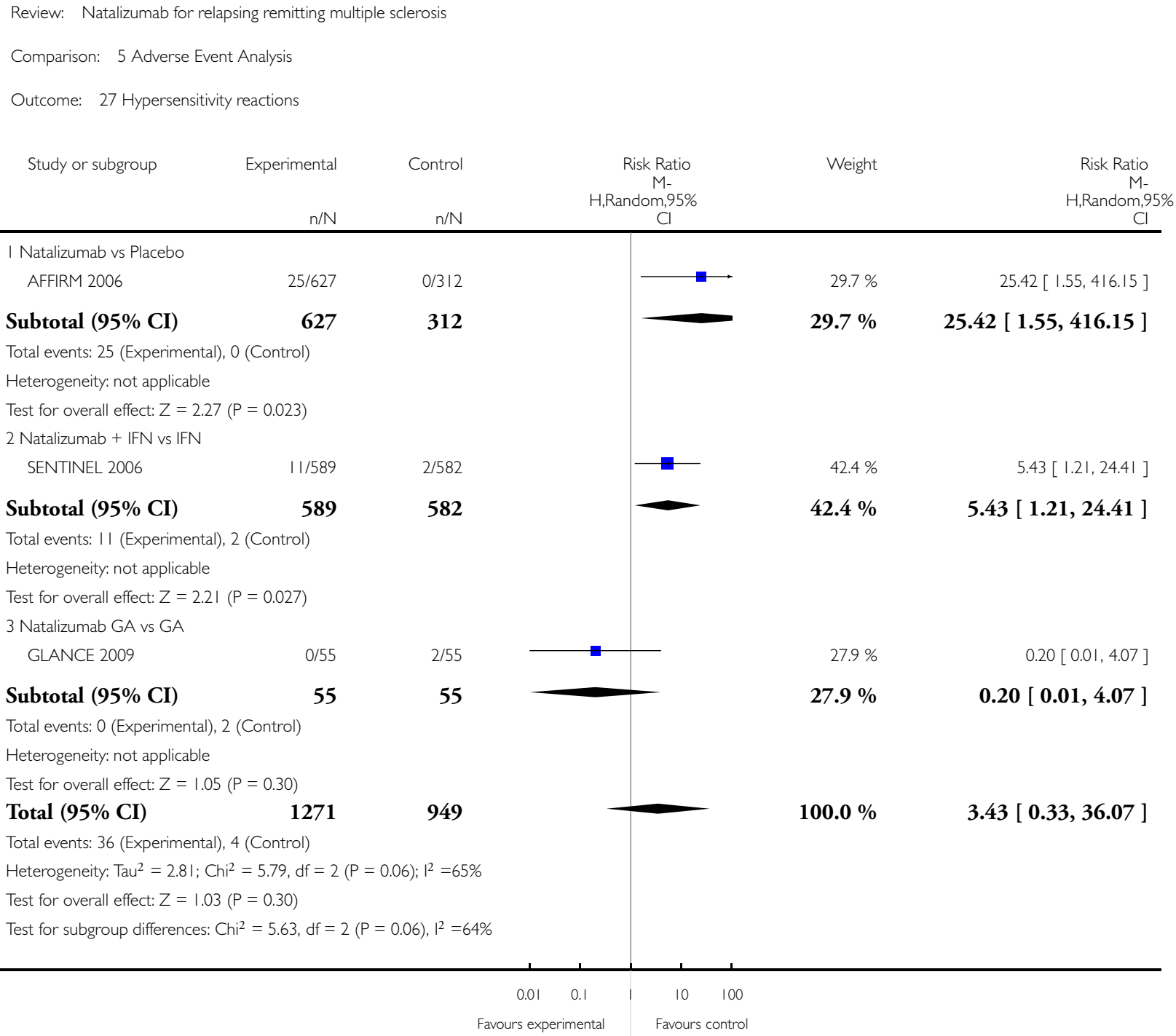




\section{Analysis 5.28. Comparison 5 Adverse Event Analysis, Outcome 28 Chest Discomfort.}

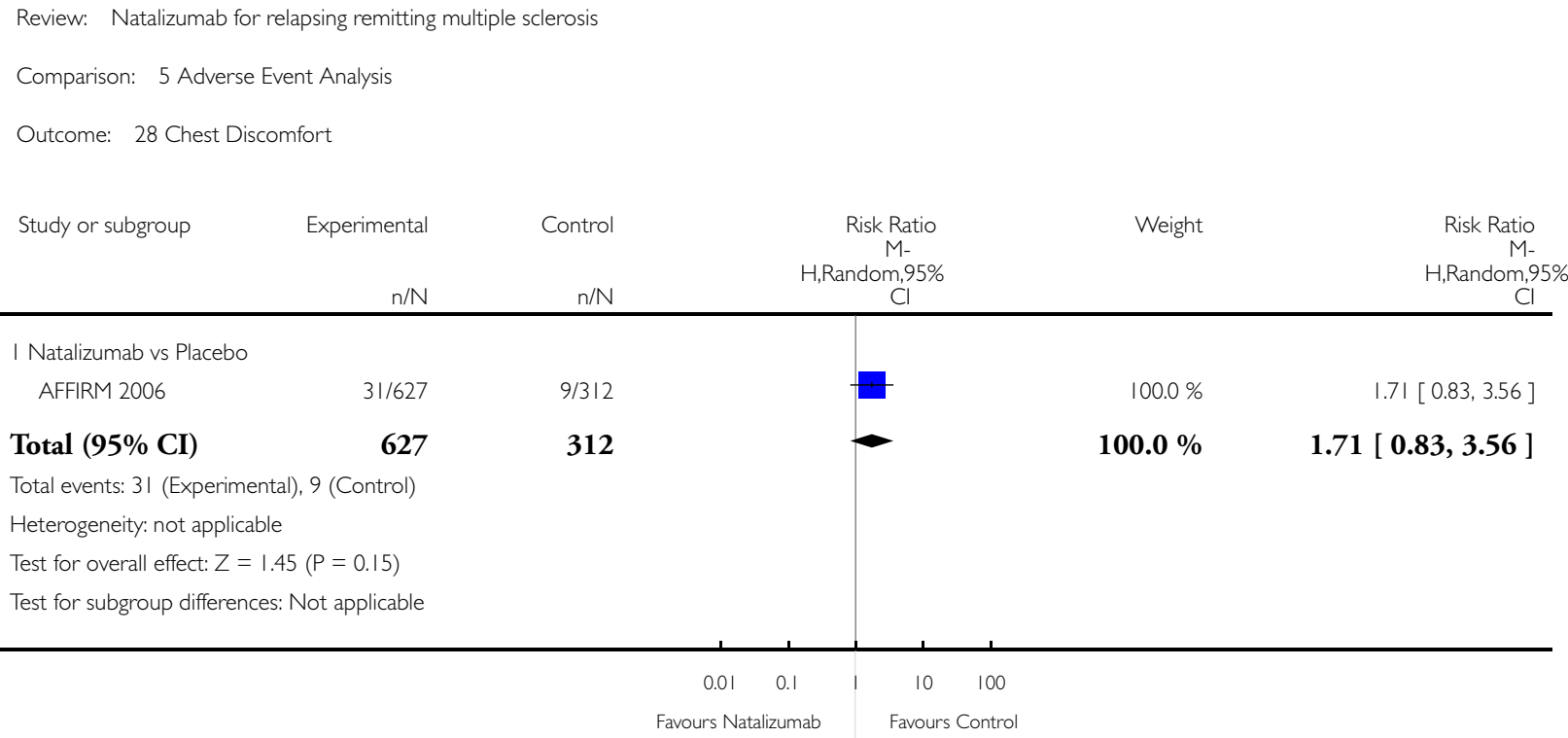

\section{Analysis 5.29. Comparison 5 Adverse Event Analysis, Outcome 29 Local Bleeding.}

Review: Natalizumab for relapsing remitting multiple sclerosis

Comparison: 5 Adverse Event Analysis

Outcome: 29 Local Bleeding

\begin{tabular}{|c|c|c|c|c|c|}
\hline Study or subgroup & Experimental & Control & $\begin{array}{c}\text { Risk Ratio } \\
\text { M- } \\
\text { H,Random,95\% } \\
\mathrm{Cl}\end{array}$ & Weight & $\begin{array}{c}\text { Risk Ratio } \\
\text { M- } \\
\text { H,Random,95\% } \\
\text { Cl }\end{array}$ \\
\hline \multicolumn{6}{|c|}{ I Natalizumab vs Placebo } \\
\hline AFFIRM 2006 & $19 / 627$ & $6 / 312$ & . & $100.0 \%$ & $1.58[0.64,3.9 \mid]$ \\
\hline
\end{tabular}

Total (95\% CI)

627

312

$100.0 \%$

$1.58[0.64,3.91]$

Total events: 19 (Experimental), 6 (Control)

Heterogeneity: not applicable

Test for overall effect: $Z=0.98(P=0.33)$

Test for subgroup differences: Not applicable

\section{$\begin{array}{lllll}0.01 & 0.1 & 1 & 10 & 100\end{array}$ \\ Favours Natalizumab Favours Control}




\section{Analysis 5.30. Comparison 5 Adverse Event Analysis, Outcome 30 Rigors.}

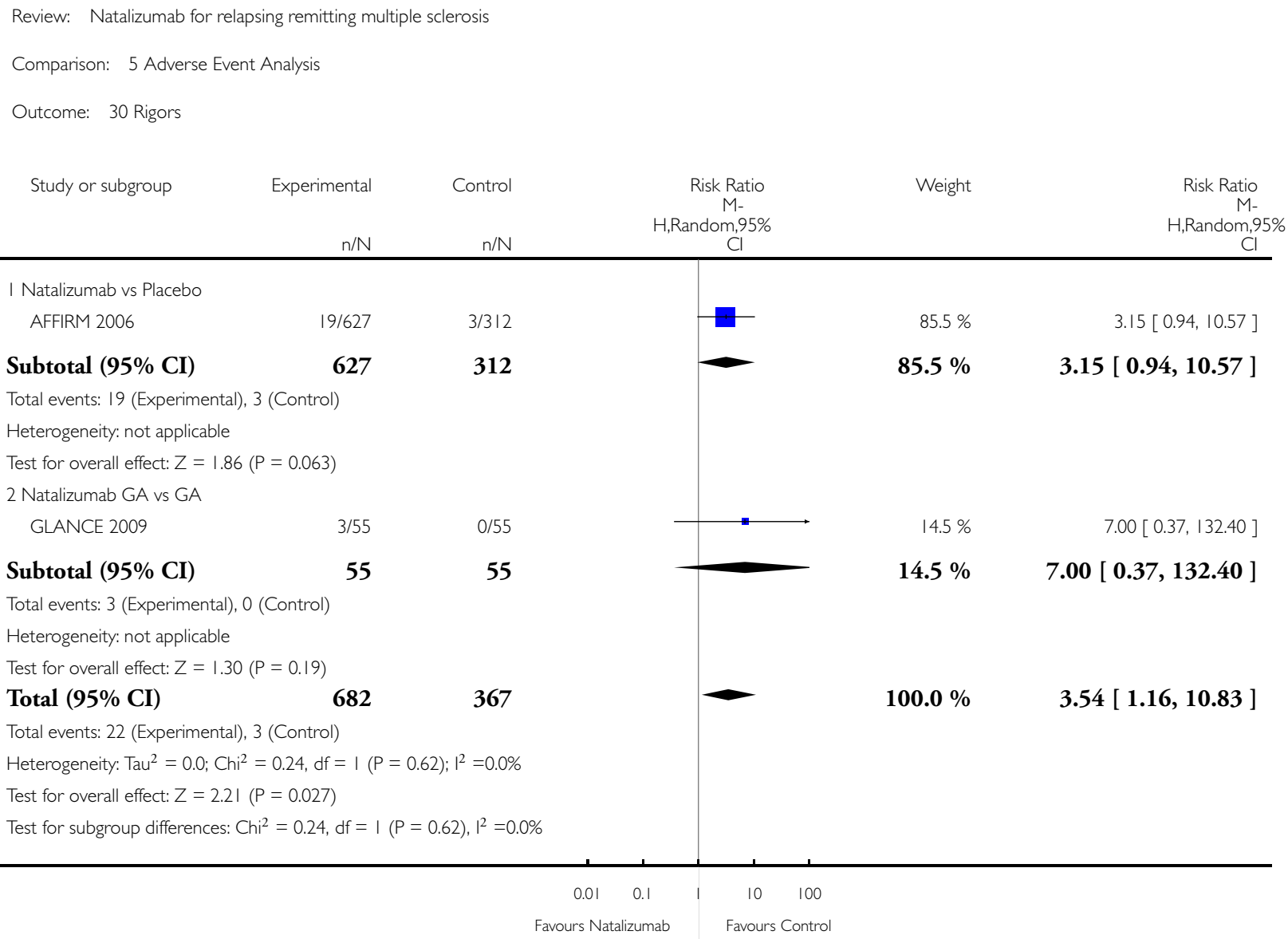




\section{Analysis 5.31. Comparison 5 Adverse Event Analysis, Outcome 3 I Syncope.}

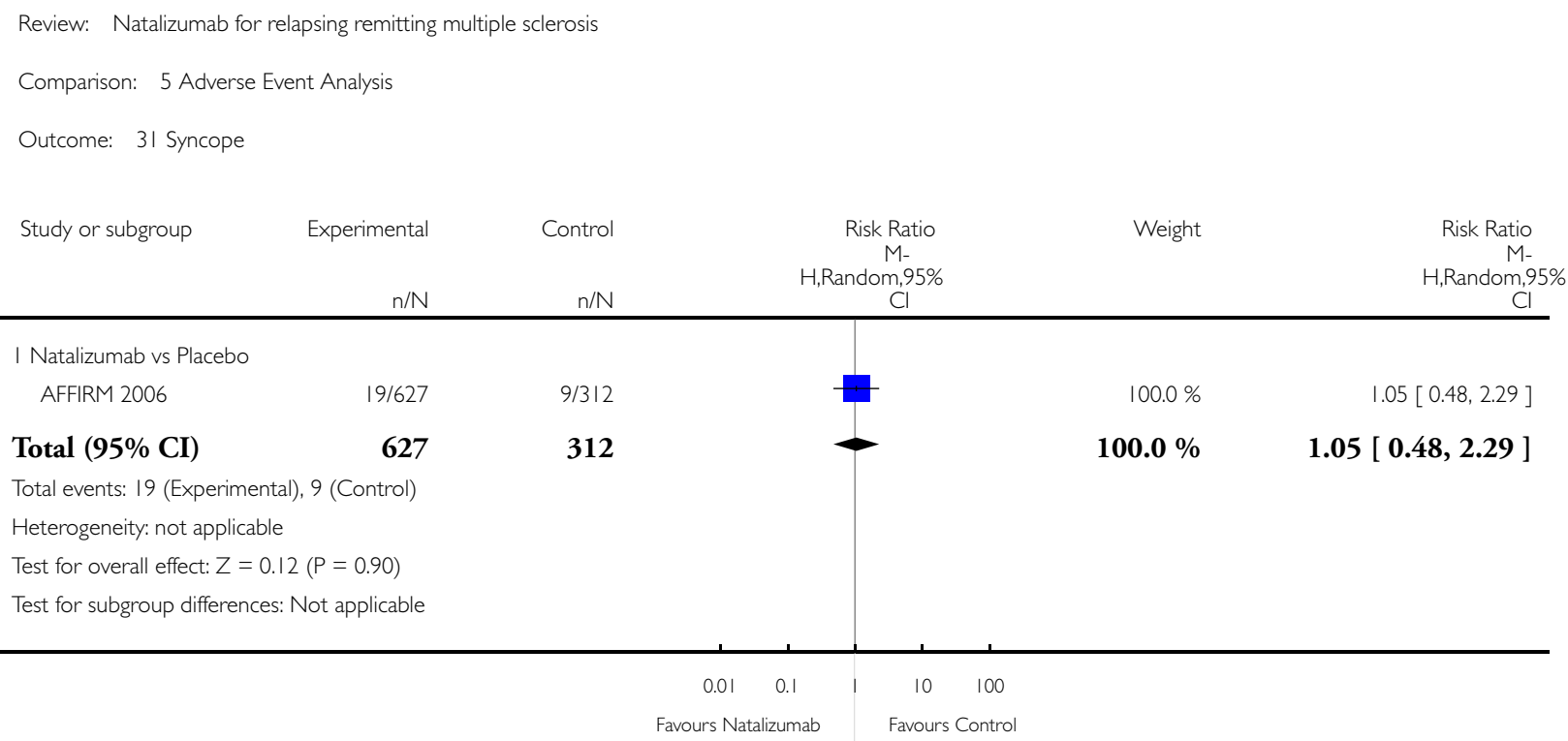




\section{Analysis 5.32. Comparison 5 Adverse Event Analysis, Outcome 32 Urinary Infection.}

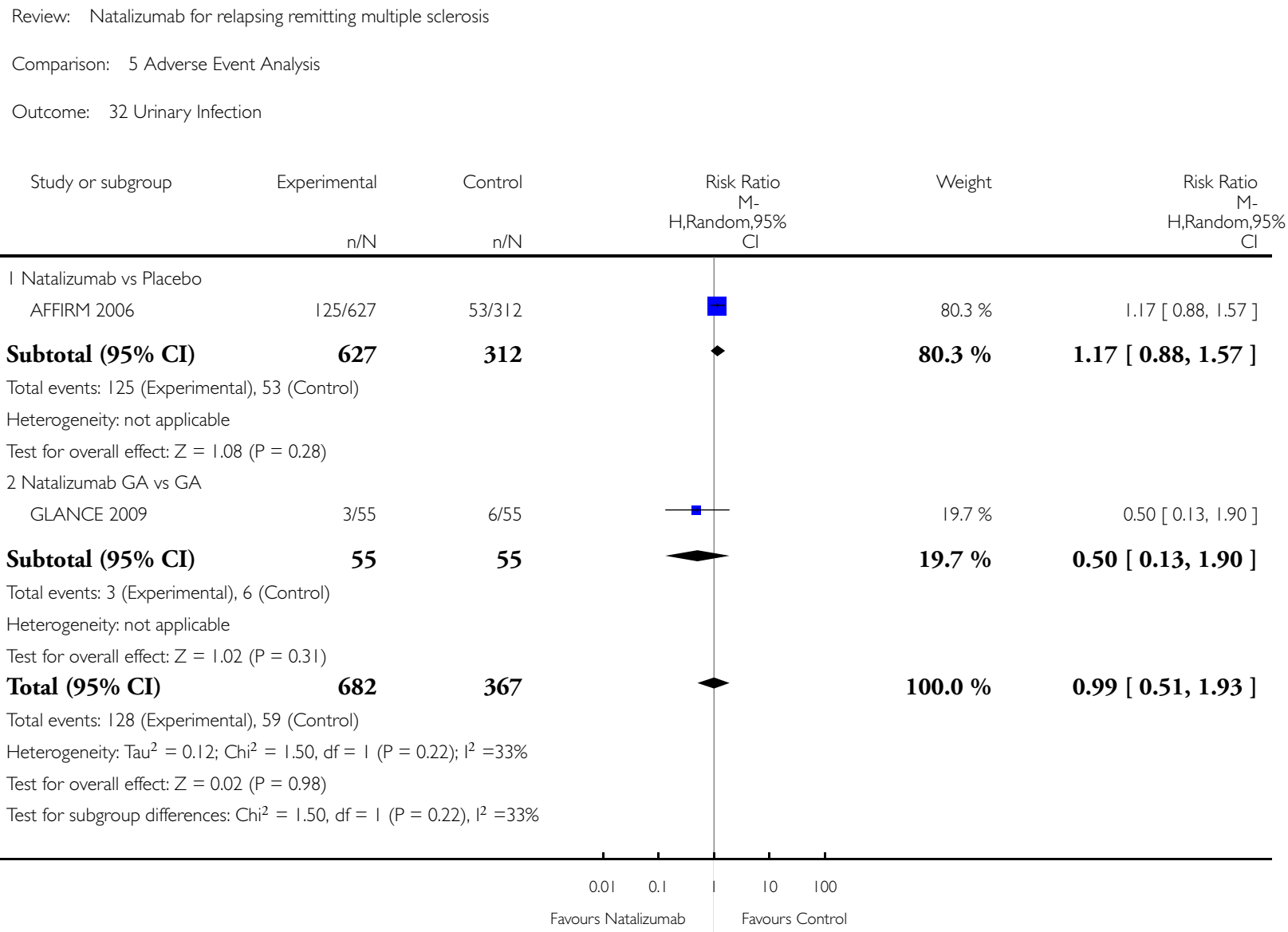




\section{Analysis 5.33. Comparison 5 Adverse Event Analysis, Outcome 33 Lower Respiratory Infection.}

Review: Natalizumab for relapsing remitting multiple sclerosis

Comparison: 5 Adverse Event Analysis

Outcome: 33 Lower Respiratory Infection

\begin{tabular}{|c|c|c|c|c|c|}
\hline Study or subgroup & Experimental & Control & $\begin{array}{r}\text { Risk Ratio } \\
\text { M- } \\
\text { H,Random,95\% } \\
\mathrm{Cl} \\
\end{array}$ & Weight & $\begin{array}{c}\text { Risk Ratio } \\
\text { M- } \\
\text { H,Random,95\% } \\
\mathrm{Cl} \\
\end{array}$ \\
\hline \multicolumn{6}{|c|}{ I Natalizumab vs Placebo } \\
\hline AFFIRM 2006 & $107 / 627$ & $50 / 312$ & - & $100.0 \%$ & $1.06[0.78,1.45]$ \\
\hline
\end{tabular}

Total (95\% CI)

627

312

$100.0 \%$

$1.06[0.78,1.45]$

Total events: 107 (Experimental), 50 (Control)

Heterogeneity: not applicable

Test for overall effect: $Z=0.40(P=0.69)$

Test for subgroup differences: Not applicable

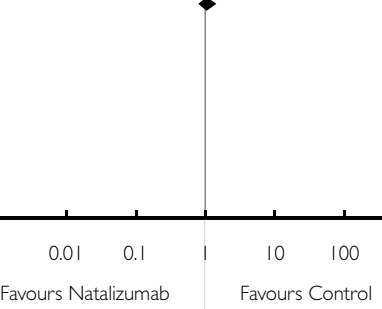

\section{Analysis 5.34. Comparison 5 Adverse Event Analysis, Outcome 34 Tonsillitis.}

Review: Natalizumab for relapsing remitting multiple sclerosis

Comparison: 5 Adverse Event Analysis

Outcome: 34 Tonsillitis

Control Risk Ratio

M-

H,Random,95\%

$\mathrm{n} / \mathrm{N} \quad \mathrm{n} / \mathrm{N}$

$\mathrm{Cl}$

Weight

Risk Ratio

I Natalizumab vs Placebo

AFFIRM 2006

$44 / 627$

$16 / 312$

$100.0 \%$

$1.37[0.78,2.39]$

Total (95\% CI)

627

312

$100.0 \%$

$1.37[0.78,2.39]$

Total events: 44 (Experimental), 16 (Control)

Heterogeneity: not applicable

Test for overall effect: $Z=1.1$ I $(P=0.27)$

Test for subgroup differences: Not applicable

\section{$\begin{array}{lllll}0.01 & 0.1 & 1 & 10 & 100\end{array}$}

Favours Natalizumab

Favours Contro

Copyright (c) 201 I The Cochrane Collaboration. Published by John Wiley \& Sons, Ltd. 


\section{Analysis 5.35. Comparison 5 Adverse Event Analysis, Outcome 35 Gastroenteritis.}

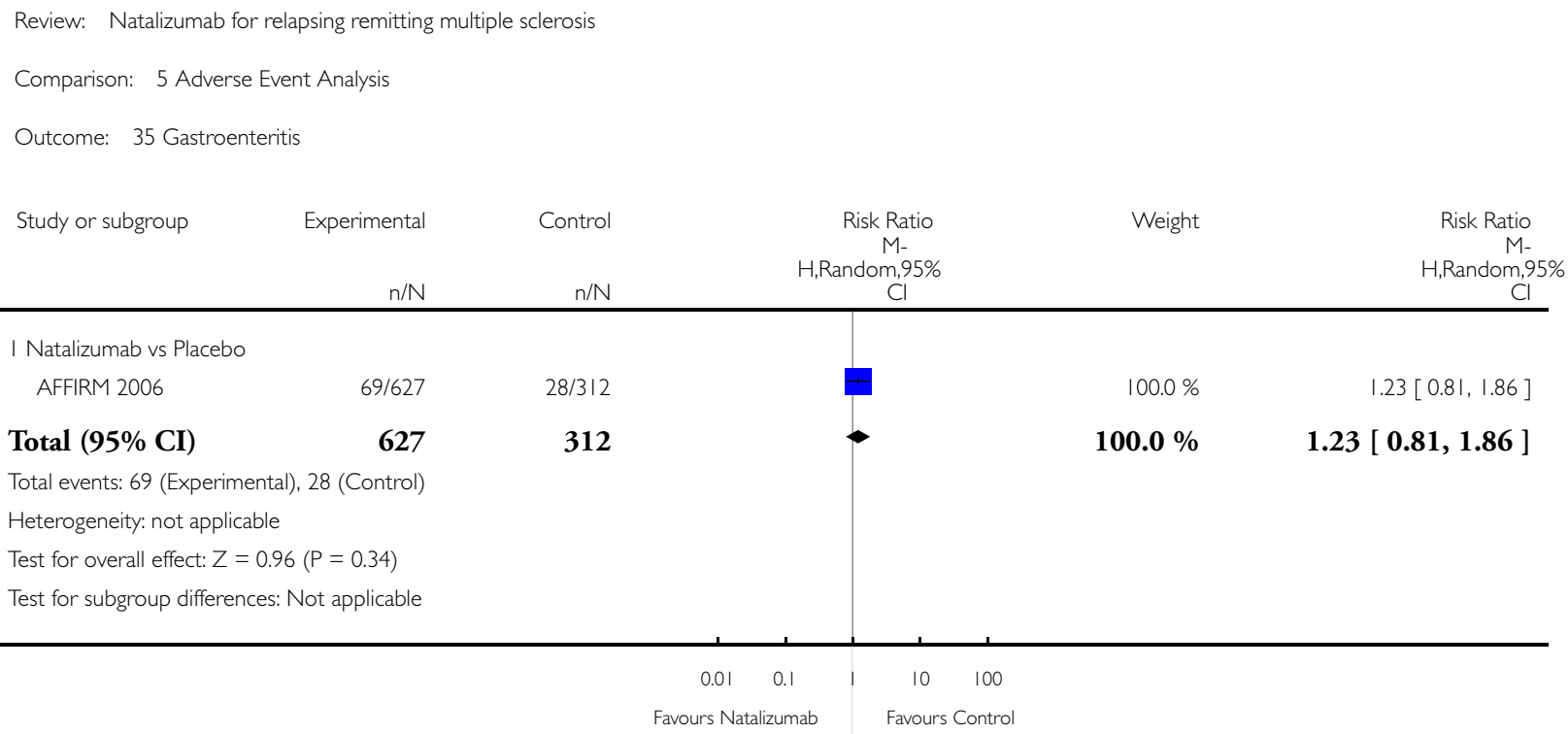




\section{Analysis 5.36. Comparison 5 Adverse Event Analysis, Outcome 36 Vaginitis.}

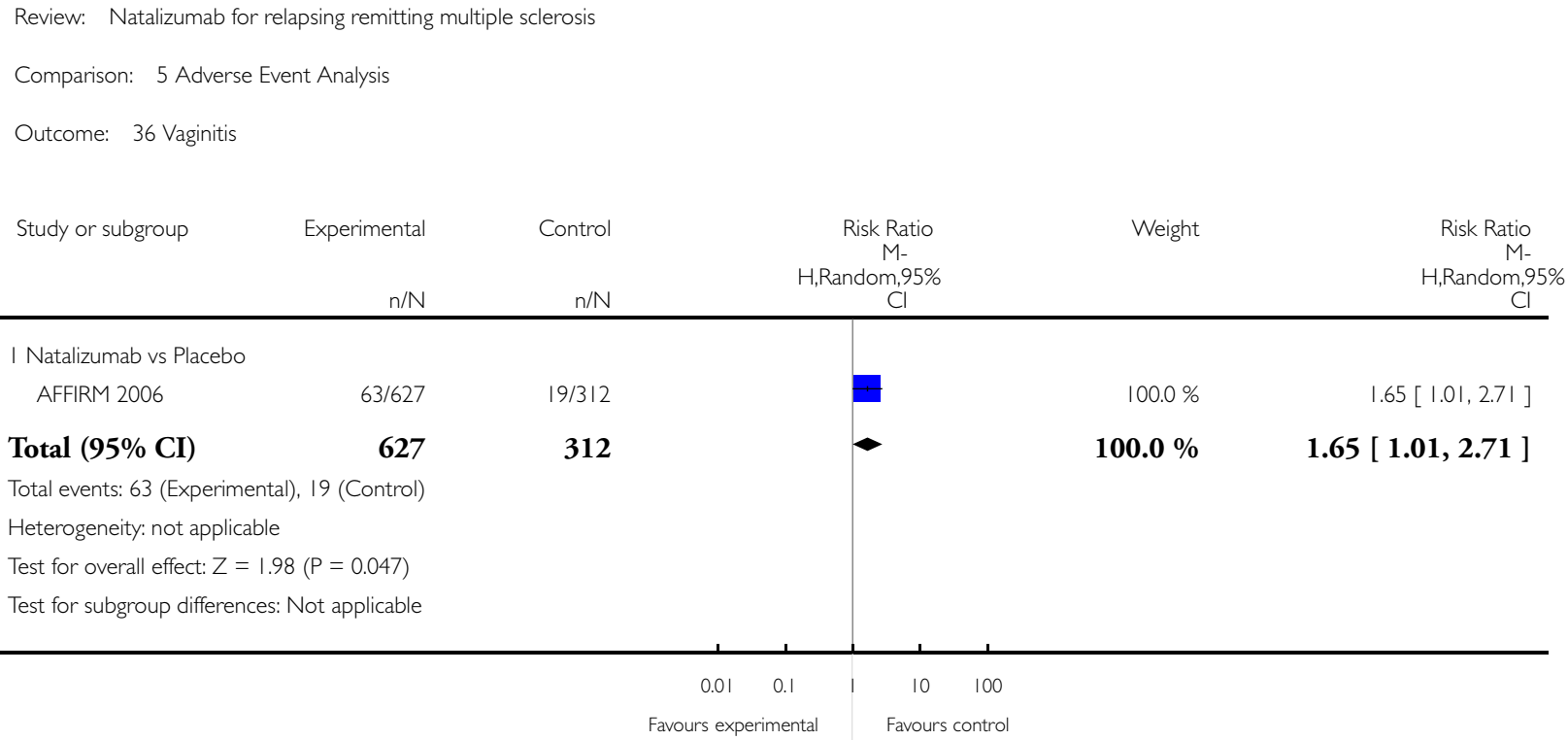

\section{Analysis 5.37. Comparison 5 Adverse Event Analysis, Outcome 37 Menstrual disorders.}

Review: Natalizumab for relapsing remitting multiple sclerosis

Comparison: 5 Adverse Event Analysis

Outcome: 37 Menstrual disorders

\begin{tabular}{|c|c|c|c|c|c|}
\hline Study or subgroup & Experimental & Control & $\begin{array}{c}\text { Risk Ratio } \\
\text { M- } \\
\text { H,Random,95\% } \\
\text { Cl }\end{array}$ & Weight & $\begin{array}{c}\text { Risk Ratio } \\
\text { M- } \\
\text { H,Random,95\% } \\
\text { Cl }\end{array}$ \\
\hline I Natalizu & & & & & \\
\hline AFFIRM 2006 & $57 / 627$ & $15 / 3 \mid 2$ & & $100.0 \%$ & $1.89[1.09,3.29]$ \\
\hline
\end{tabular}

Total (95\% CI)

627

312

$100.0 \%$

$1.89[1.09,3.29]$

Total events: 57 (Experimental), 15 (Control)

Heterogeneity: not applicable

Test for overall effect: $Z=2.26(P=0.024)$

Test for subgroup differences: Not applicable

$\begin{array}{ccccc}0.01 & 0.1 & 1 & 10 & 100 \\ \text { Favours Natalizumab } & & \text { Favours } & \text { Control }\end{array}$ 


\section{Analysis 5.38. Comparison 5 Adverse Event Analysis, Outcome 38 Skin Rash.}

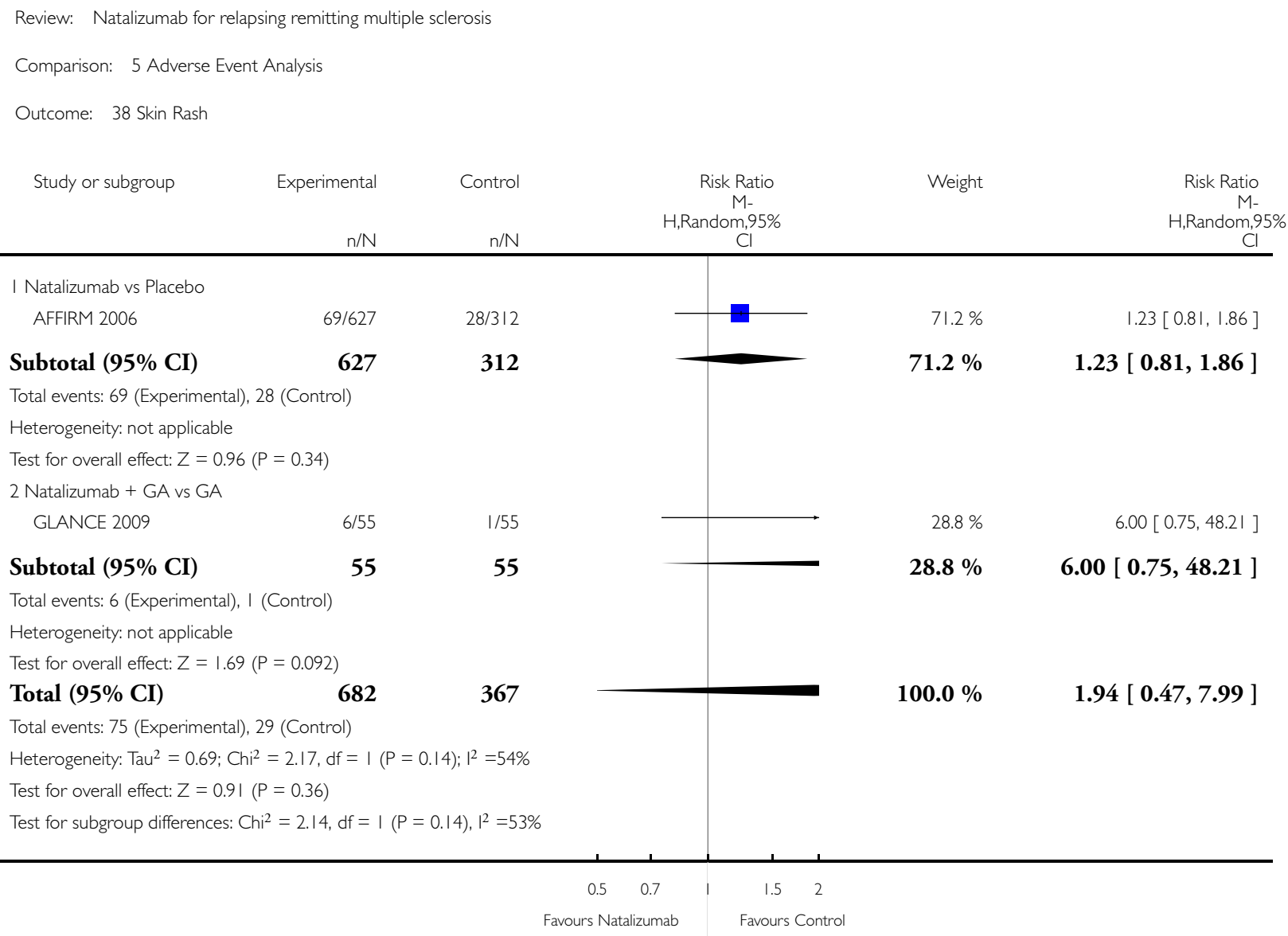




\section{Analysis 5.39. Comparison 5 Adverse Event Analysis, Outcome 39 Dermatitis.}

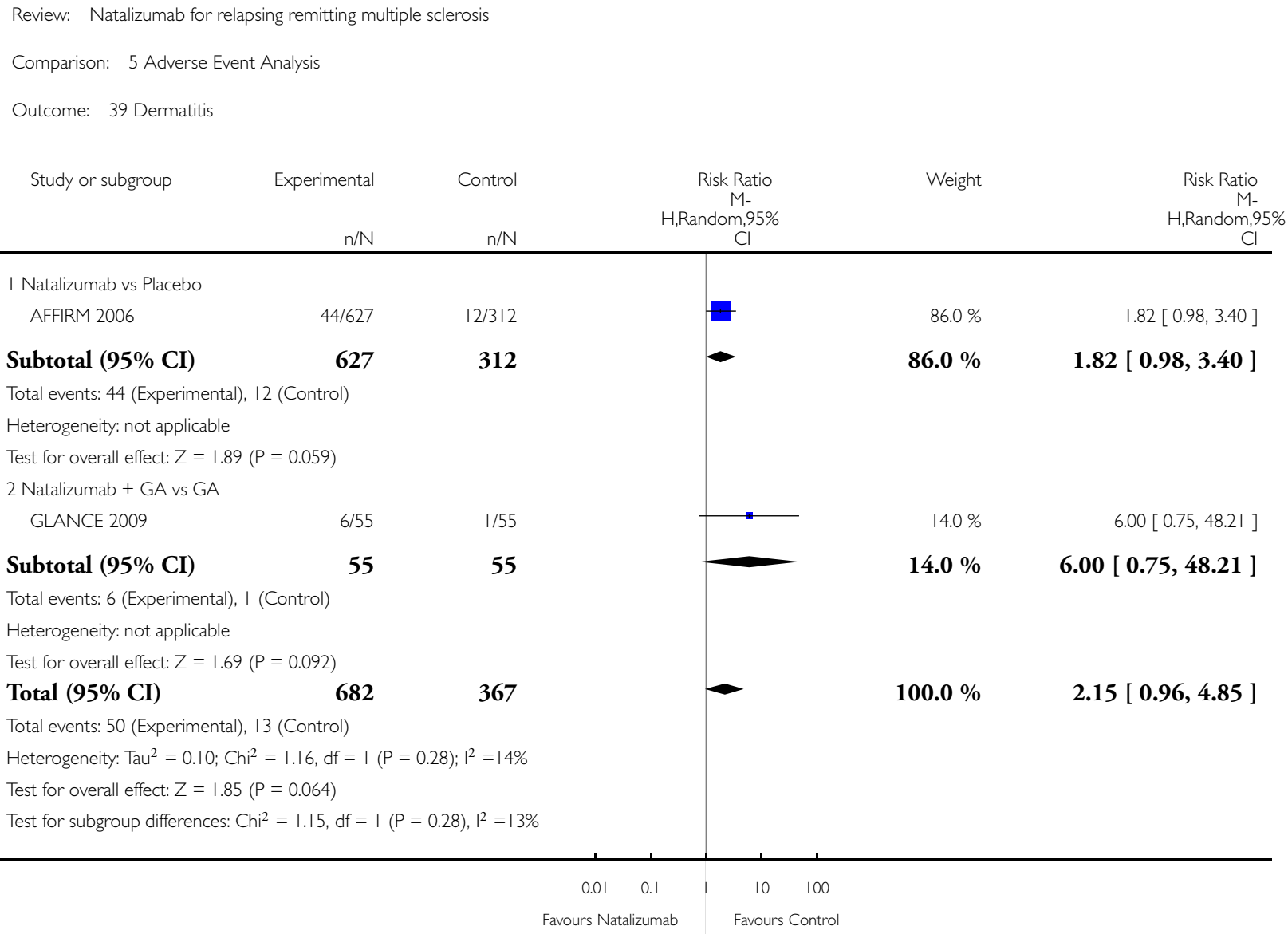




\section{Analysis 5.40. Comparison 5 Adverse Event Analysis, Outcome 40 Pruritus.}

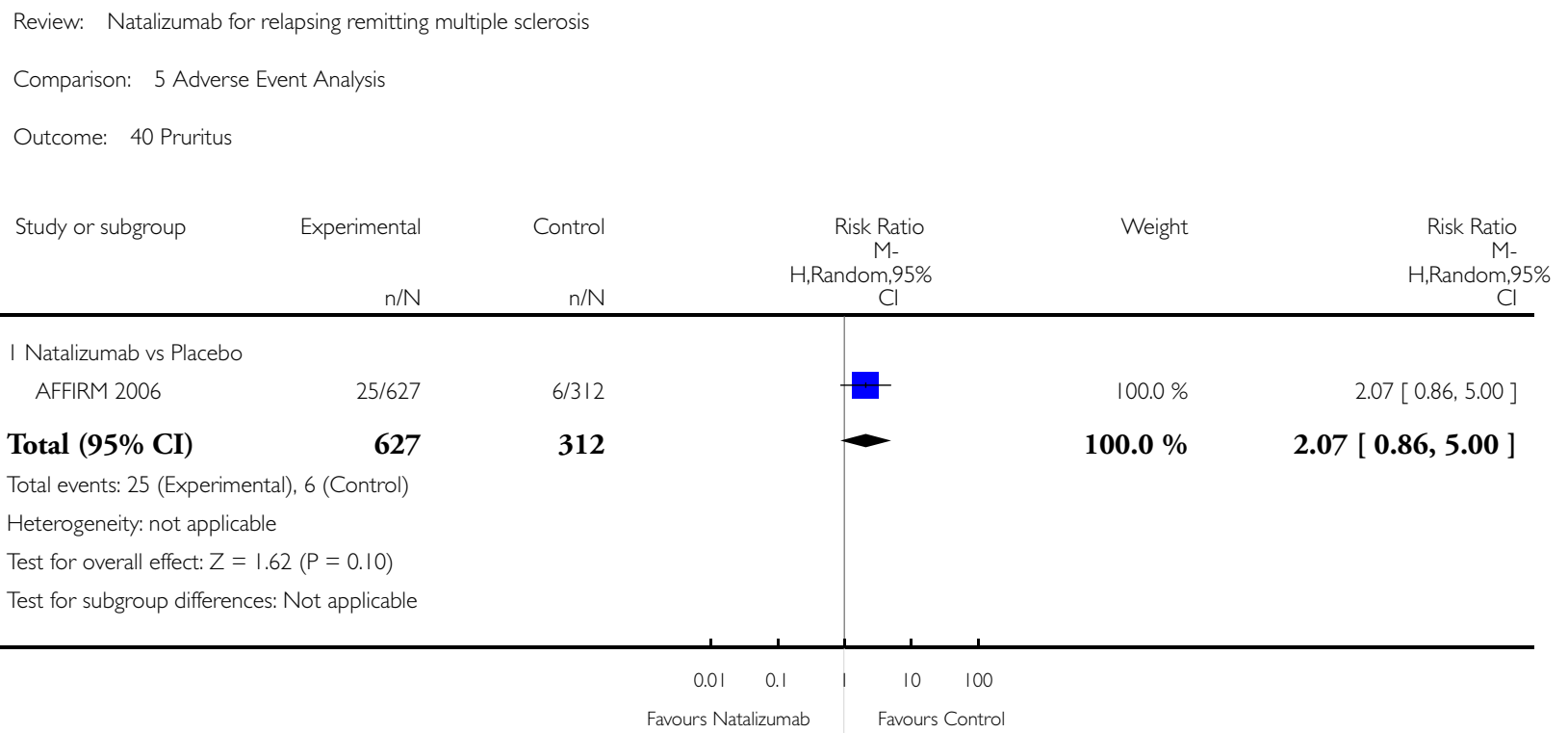

Analysis 5.41. Comparison 5 Adverse Event Analysis, Outcome 4 I Vertigo.

Review: Natalizumab for relapsing remitting multiple sclerosis

Comparison: 5 Adverse Event Analysis

Outcome: 41 Vertigo

$\begin{array}{llll}\text { Study or subgroup } & \text { Experimental Risk Ratio } & \text { Control } & \text { Wisk Ratio }\end{array}$

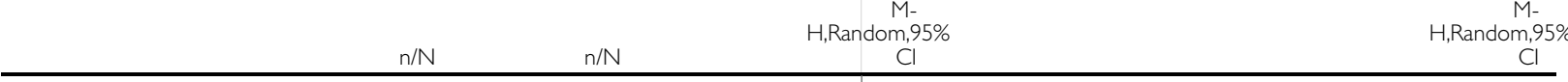

I Natalizumab vs Placebo

$\begin{array}{llll}\text { AFFIRM } 2006 & 38 / 627 & 16 / 312 & 100.0 \% \quad 0.67,2.09]\end{array}$

Total (95\% CI)

627

312

$100.0 \%$

$1.18[0.67,2.09]$

Total events: 38 (Experimental), 16 (Control)

Heterogeneity: not applicable

Test for overall effect: $Z=0.58(P=0.56)$

Test for subgroup differences: Not applicable

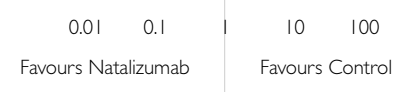




\section{Analysis 5.42. Comparison 5 Adverse Event Analysis, Outcome 42 Infection.}

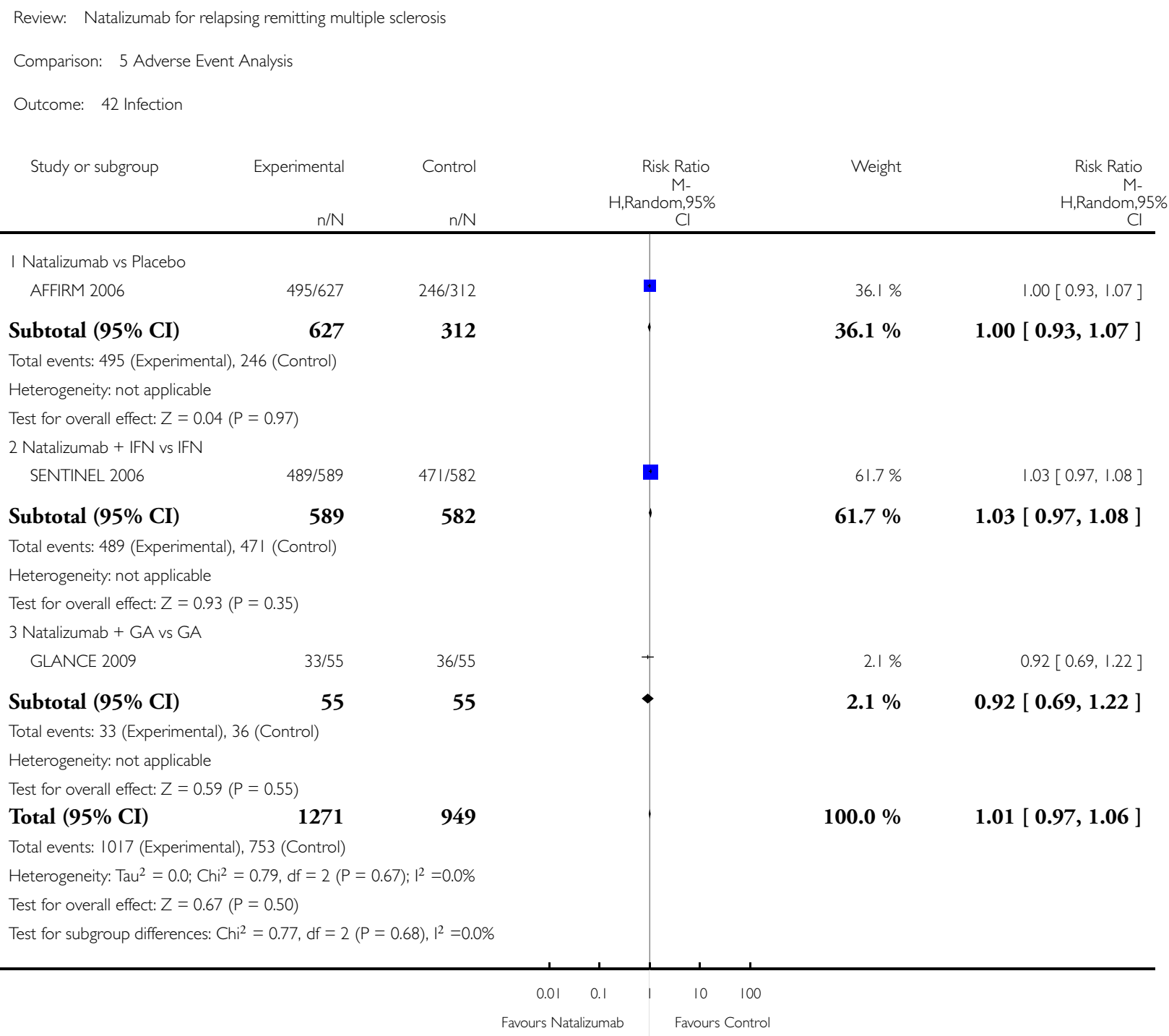




\section{Analysis 5.43. Comparison 5 Adverse Event Analysis, Outcome 43 Infusion reactions.}

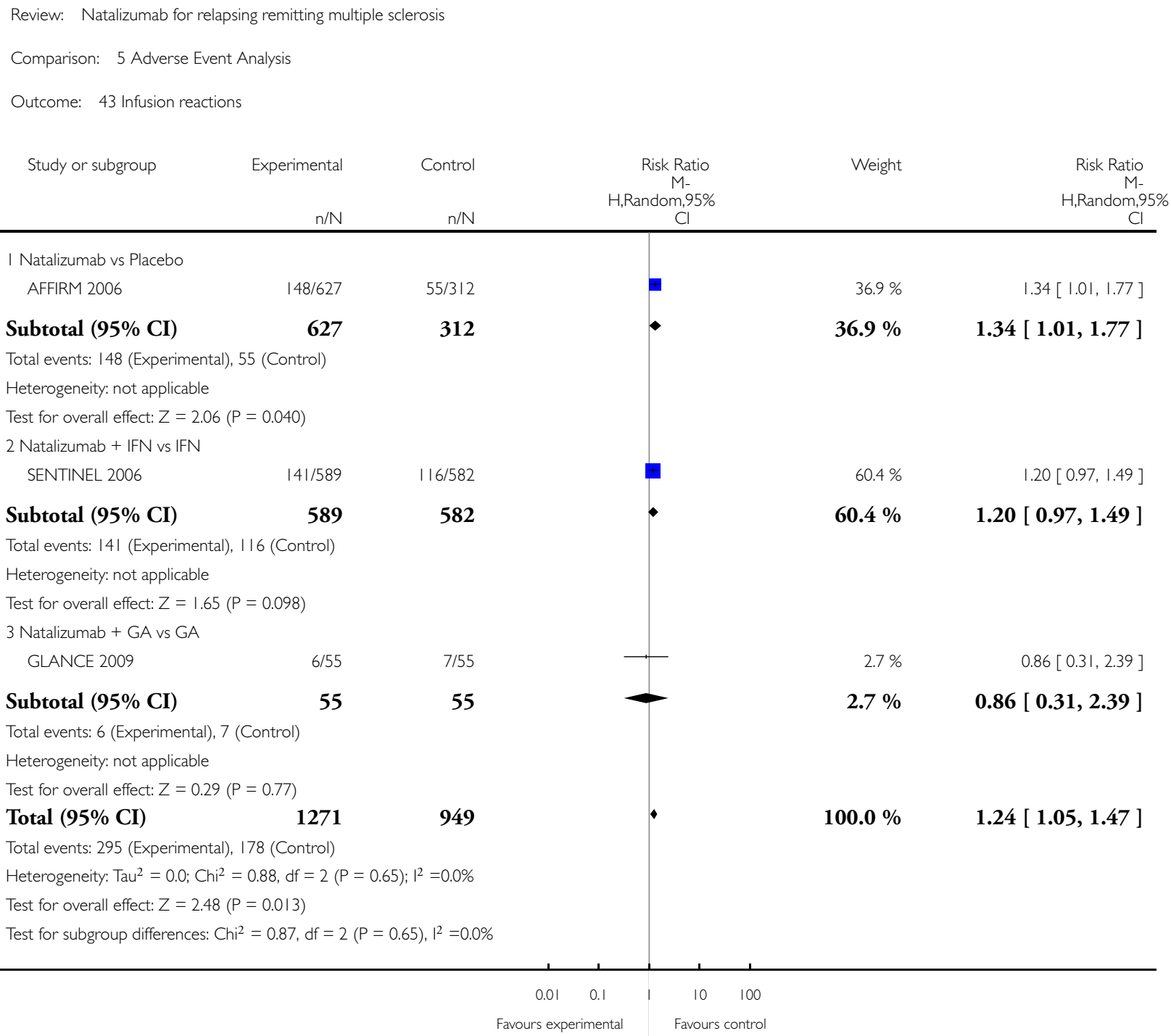




\section{Analysis 5.44. Comparison 5 Adverse Event Analysis, Outcome 44 Back Pain.}

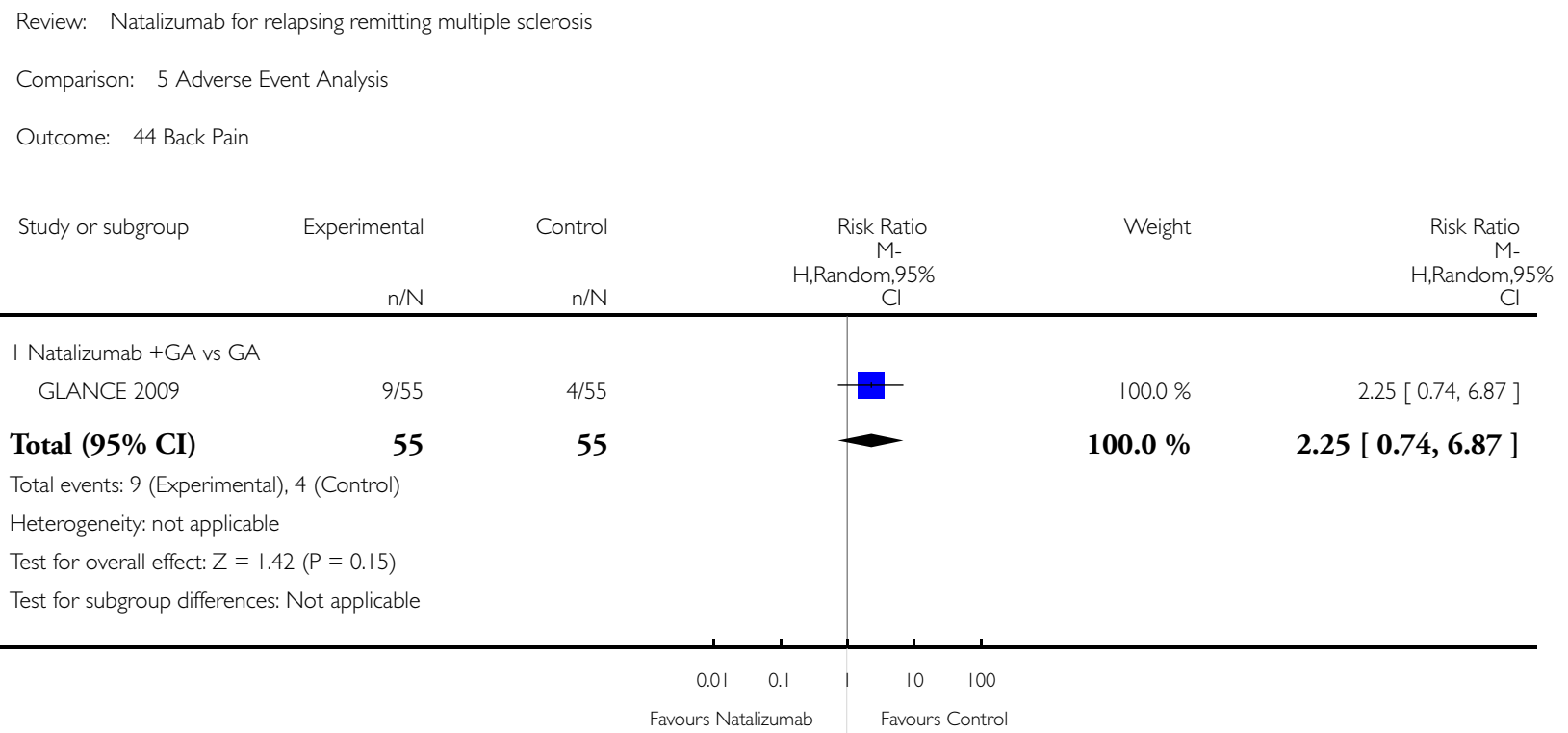

\section{Analysis 5.45. Comparison 5 Adverse Event Analysis, Outcome 45 Fall.}

Review: Natalizumab for relapsing remitting multiple sclerosis

Comparison: 5 Adverse Event Analysis

Outcome: 45 Fall

\begin{tabular}{|c|c|c|c|c|c|}
\hline Study or subgroup & $\begin{array}{r}\text { Experimental } \\
n / N\end{array}$ & $\begin{array}{l}\text { Control } \\
n / N\end{array}$ & $\begin{array}{c}\text { Risk Ratio } \\
\text { M- } \\
\text { H,Random,95\% } \\
\text { Cl }\end{array}$ & Weight & $\begin{array}{c}\text { Risk Ratio } \\
\text { M- } \\
\text { H,Random,95\% } \\
\mathrm{Cl}\end{array}$ \\
\hline AFFIRM 2006 & $5 / 627$ & $2 / 312$ & $\square$ & $64.5 \%$ & $1.24[0.24,6.38]$ \\
\hline SENTINEL 2006 & $5 / 589$ & 0/582 & + & $35.5 \%$ & $10.87[0.60,196.13]$ \\
\hline Total $(95 \%$ CI $)$ & 1216 & 894 & & $100.0 \%$ & $2.69[0.32,22.39]$ \\
\hline
\end{tabular}

Total events: 10 (Experimental), 2 (Control)

Heterogeneity: $\operatorname{Tau}^{2}=1.12 ; \mathrm{Ch}^{2}=1.78, \mathrm{df}=1(\mathrm{P}=0.18) ; \mathrm{I}^{2}=44 \%$

Test for overall effect: $Z=0.91(P=0.36)$

Test for subgroup differences: Not applicable

$\begin{array}{ccccc}0.01 & 0.1 & 1 & 10 & 100 \\ & \text { Favours experimental } & & \text { Favours control }\end{array}$ 


\section{Analysis 5.46. Comparison 5 Adverse Event Analysis, Outcome 46 Neoplasms.}

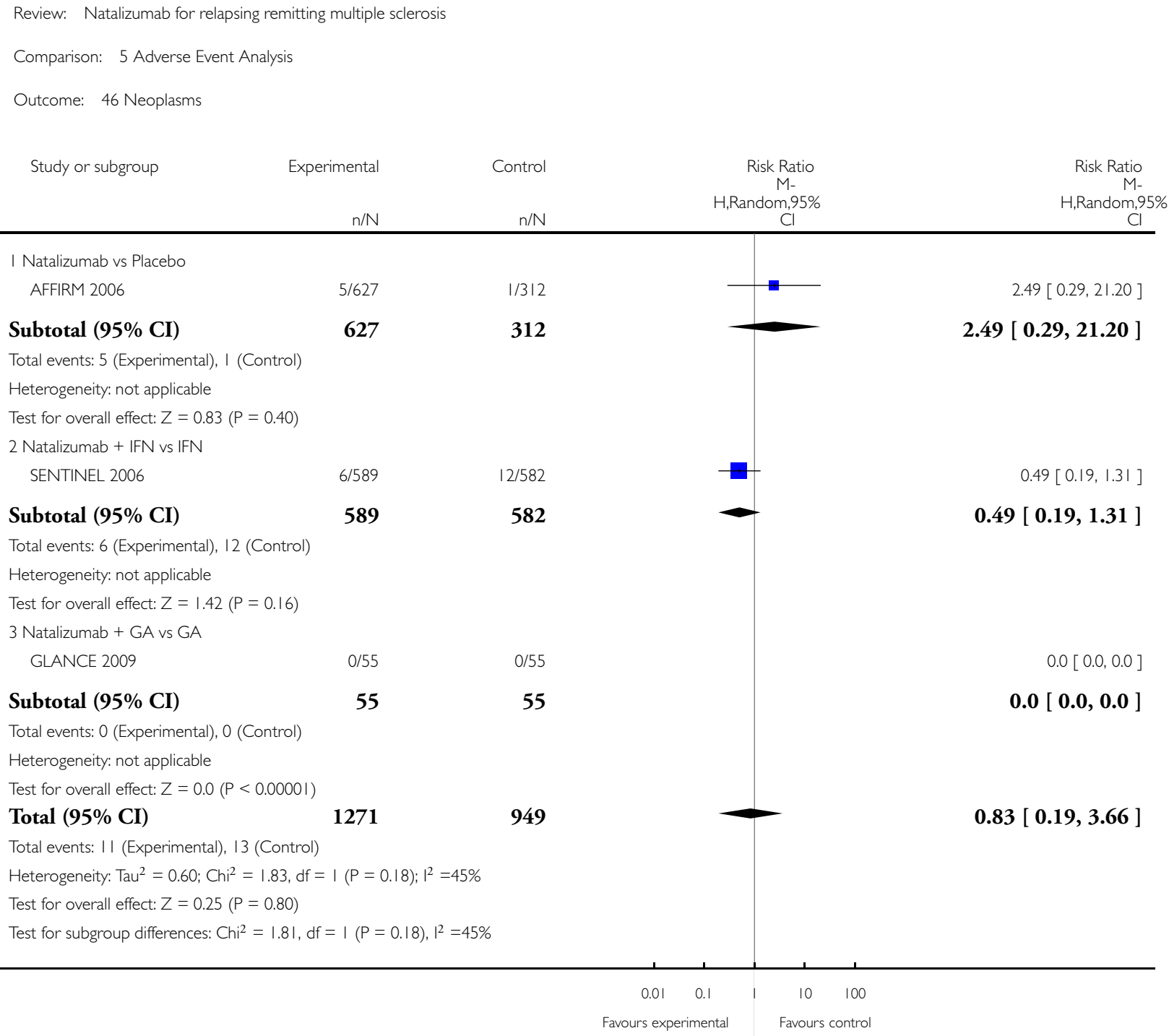




\section{Analysis 5.47. Comparison 5 Adverse Event Analysis, Outcome 47 Abnormal liver function tests.}

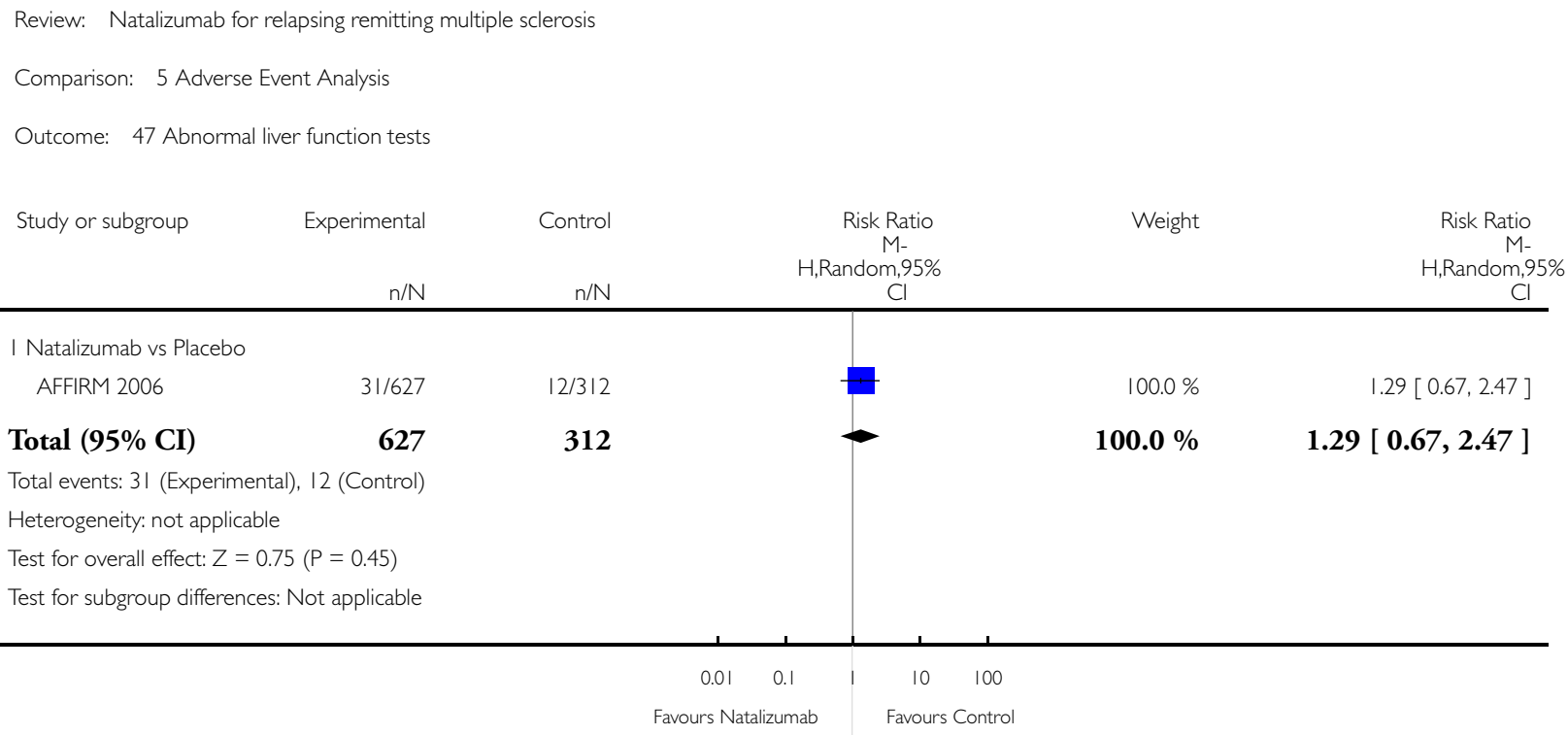




\section{Analysis 5.48. Comparison 5 Adverse Event Analysis, Outcome 48 Death.}

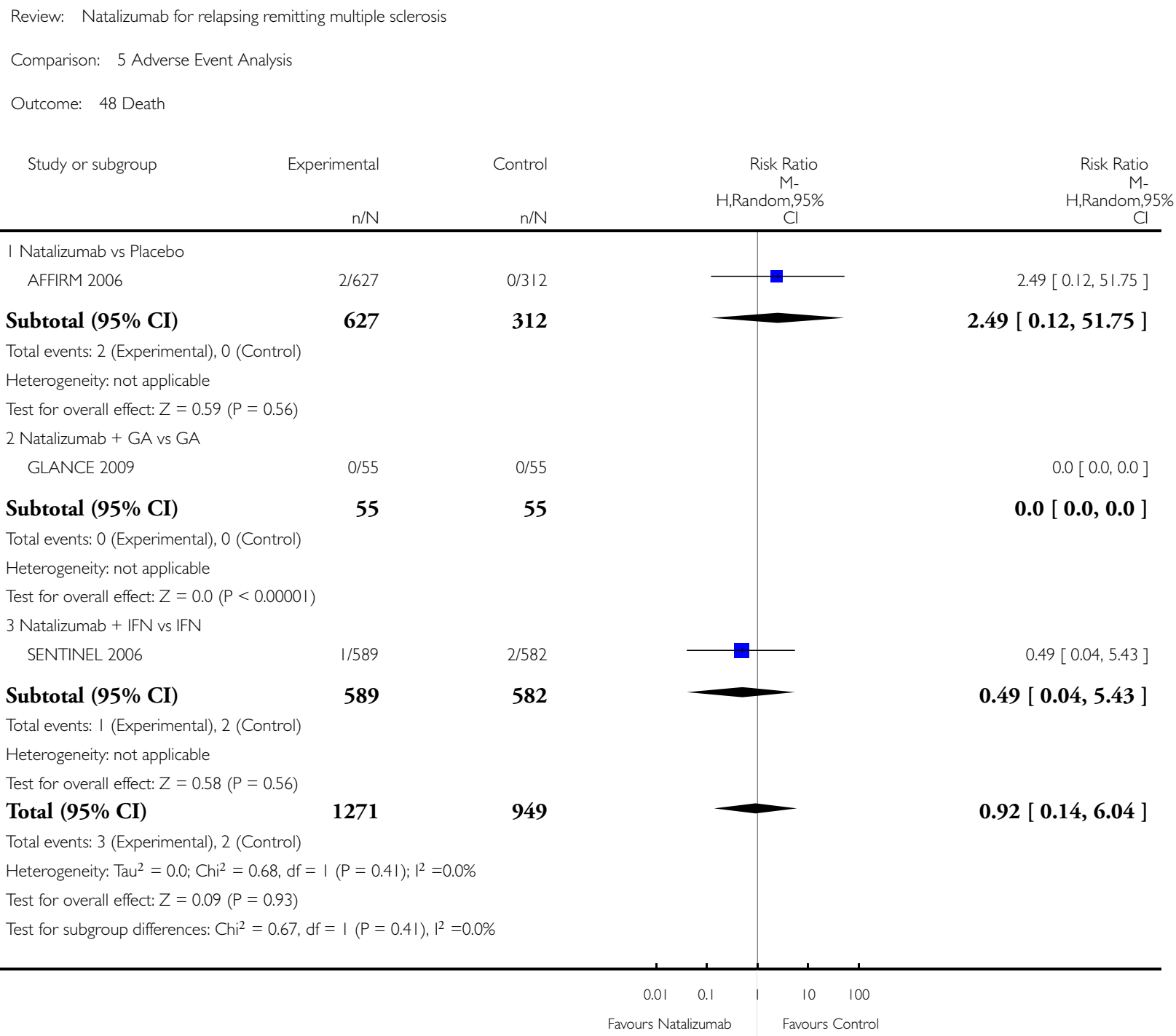




\section{Analysis 5.49. Comparison 5 Adverse Event Analysis, Outcome 49 MS relapse as a serious AE.}

Review: Natalizumab for relapsing remitting multiple sclerosis

Comparison: 5 Adverse Event Analysis

Outcome: $49 \mathrm{MS}$ relapse as a serious $\mathrm{AE}$

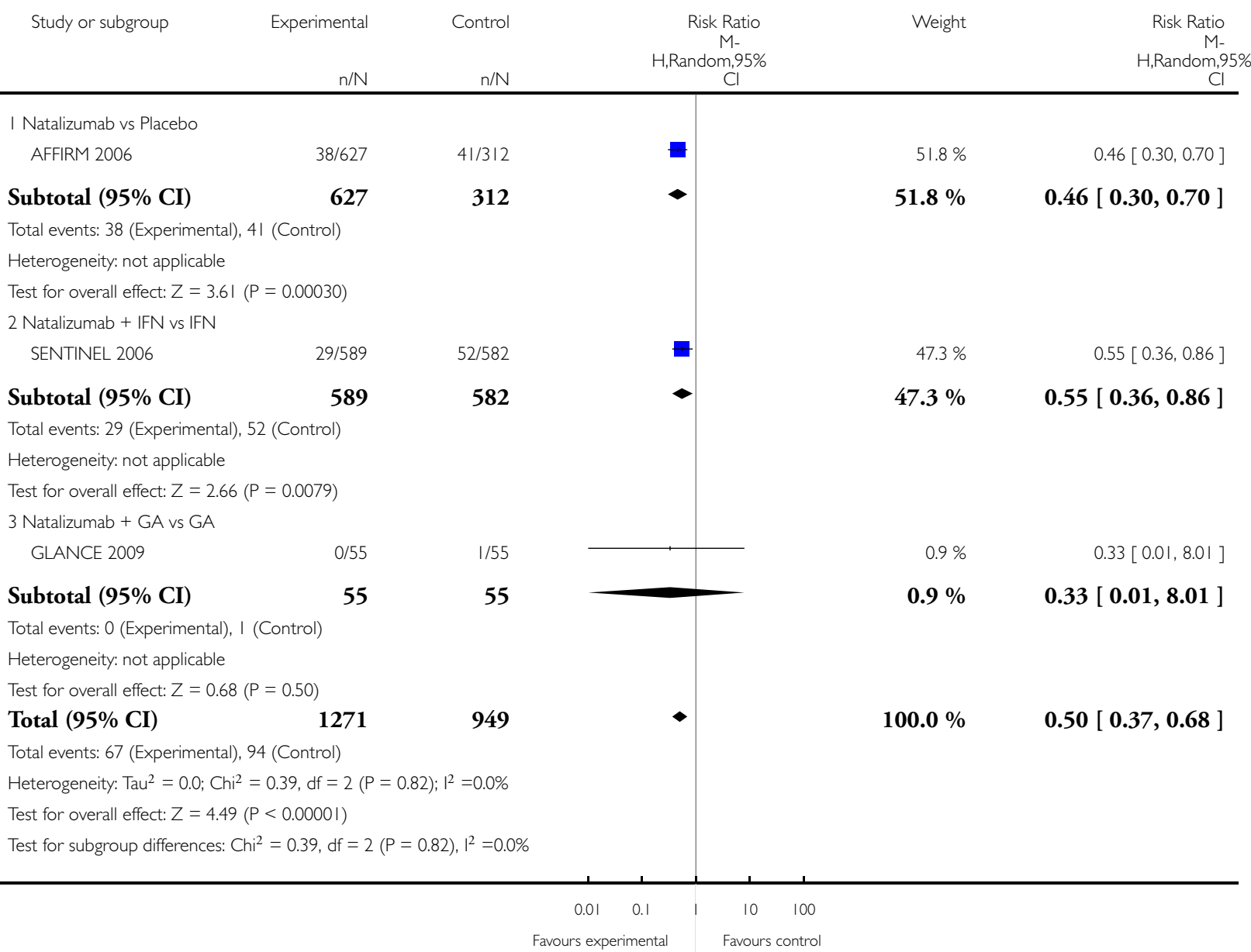


ADDITIONAL TABLES

Table 1. ABBREVIATIONS

\begin{tabular}{|c|c|}
\hline ABBREVIATION & TERM \\
\hline AIFA & Agenzia Italiana Farmaco \\
\hline $\mathrm{CD}$ & Crohn Disease \\
\hline CDER & Center for drug evaluation and research (FDA) \\
\hline $\mathrm{CI}$ & Confidence Interval \\
\hline CNS & Central Nervous System \\
\hline CIS & Clinically Isolated Syndrome \\
\hline DMDs & Disease-Modifying Drugs \\
\hline EDSS & Expanded Disability Status Scale \\
\hline EMA & European Medicines Agency \\
\hline FDA & Food and Drug Administration \\
\hline GA & Glatiramer Acetate $\left(\right.$ Copaxone ${ }^{\circledR}$ ) \\
\hline $\mathrm{Gd}+$ & Gadolinium enhancing lesion in MRI \\
\hline HRQoL & Health Related Quality of Life \\
\hline HSRs & hypersensitivity reactions \\
\hline IFNß & Interferon beta \\
\hline IFNß-1a & Interferon beta-1a \\
\hline $\operatorname{IgG}$ & Immunoglobulin $\mathrm{G}$ \\
\hline IRIS & Immune reconstitution inflammatory syndrome \\
\hline ITT & intention-to-treat \\
\hline IV & intravenous \\
\hline MCS & Mental Component Summary (composite scores of SF-36) \\
\hline MD & mean difference \\
\hline MFIS & Modified Fatigue Impact Scale \\
\hline
\end{tabular}


Table 1. ABBREVIATIONS (Continued)

\begin{tabular}{|c|c|}
\hline MSFC & Multiple Sclerosis Functional Composite \\
\hline MRI & Magnetic resonance imaging \\
\hline MS & Multiple Sclerosis \\
\hline $\mathrm{N}$ & number \\
\hline n.a. & not available \\
\hline NICE & National Institute for Clinical Excellence \\
\hline NNB & Number Needed to Benefit \\
\hline $\mathrm{NNH}$ & Number Needed to Harm \\
\hline NNT & Number Needed to Treat \\
\hline NTZ & natalizumab \\
\hline PASAT & Paced Auditory Serial Addition Task (one of the components of MSFC) \\
\hline PCS & Physical Component Summary (composite scores of SF-36) \\
\hline PML & Progressive Multifocal Leukoencephalopathy \\
\hline QoL & Quality of Life \\
\hline SF-36 & Short Form 36 \\
\hline VAS & Visual Analog Scale \\
\hline
\end{tabular}

Table 2. Baseline patient characteristics in studies which contributed to primary efficacy outcomes (AFFIRM and SENTINEL)

\begin{tabular}{l|l|l|l}
\hline Characteristic & $\begin{array}{l}\text { Patients randomised to NTZ } \\
(\text { with or without IFNß-1a) } \\
(\mathrm{n}=1216)\end{array}$ & $\begin{array}{l}\text { Patients randomised to placebo } \\
\text { or IFNß-1a alone } \\
(\mathrm{n}=897)\end{array}$ & $\begin{array}{l}\text { Total } \\
(\mathrm{n}=2113)\end{array}$ \\
\hline Age range & $18-55$ & $19-55$ & $18-55$ \\
\hline $\begin{array}{l}\text { Sex } \\
\mathrm{N} \text { of male: N of female }\end{array}$ & $325: 891$ & $266: 631$ & $591: 1522$ \\
\hline $\begin{array}{l}\text { Disease duration* } \\
\text { (range) }\end{array}$ & $1-41$ & $1-34$ & \\
\hline
\end{tabular}


Table 2. Baseline patient characteristics in studies which contributed to primary efficacy outcomes (AFFIRM and SENTINEL) (Continued)

\begin{tabular}{|c|c|c|c|}
\hline $\begin{array}{l}\mathrm{N} \text { of patients with } 1 \text { relapse in } \\
\text { previous } 1 \mathrm{yr}(\% \text { of total) }\end{array}$ & 758 & 537 & $1295(61)$ \\
\hline $\begin{array}{l}\mathrm{N} \text { of patients with } \geq 2 \text { relapse } \\
\text { in previous } 1 \mathrm{yr}(\% \text { of total })\end{array}$ & 450 & 353 & $803(38)$ \\
\hline $\begin{array}{l}\mathrm{N} \text { of patients with } \mathrm{EDSS} \leq 3.5 \\
(\% \text { of total })\end{array}$ & 1056 & 769 & 1825 \\
\hline $\begin{array}{l}\mathrm{N} \text { of patients with EDSS }>3.5 \\
(\% \text { of total })\end{array}$ & 160 & 128 & 288 \\
\hline $\begin{array}{l}\mathrm{N} \text { of patients with } 0 \mathrm{Gd}+(\% \text { of } \\
\text { total) }\end{array}$ & 699 & 544 & 1243 \\
\hline $\begin{array}{l}\mathrm{N} \text { of patients with } \geq 1 \mathrm{Gd}+(\% \\
\text { of total })\end{array}$ & 511 & 348 & $859(41)$ \\
\hline $\begin{array}{l}\text { Duration } \geq 10 \text { months of pre- } \\
\text { vious IFNß-1a therapy } \\
\text { ( } \% \text { of total) }\end{array}$ & 589 & 582 & $1171(55)$ \\
\hline
\end{tabular}

Table 3. Protocol violations in AFFIRM trial

\begin{tabular}{|c|c|c|c|c|c|c|c|c|}
\hline $\begin{array}{l}\text { Type of pro- } \\
\text { tocol viola- } \\
\text { tion }\end{array}$ & $\begin{array}{l}\mathrm{N} \text { of } \\
\text { violations in } \\
\text { NTZ group }\end{array}$ & $\begin{array}{l}\mathrm{N} \text { of } \\
\text { patients } \\
\text { with at least } \\
\text { one protocol } \\
\text { violation in } \\
\text { NTZ group }\end{array}$ & $\begin{array}{l}\mathrm{N} \text { of viola- } \\
\text { tions in con- } \\
\text { trol group }\end{array}$ & $\begin{array}{l}\mathrm{N} \text { of } \\
\text { patients } \\
\text { with at least } \\
\text { one protocol } \\
\text { viola- } \\
\text { tion in con- } \\
\text { trol group }\end{array}$ & $\begin{array}{l}\text { Total } \mathrm{N} \text { of } \\
\text { violations in } \\
\text { all ran- } \\
\text { domised pa- } \\
\text { tients }\end{array}$ & $\begin{array}{l}\text { Total } \mathrm{N} \text { of } \\
\text { patients } \\
\text { with at least } \\
\text { one protocol } \\
\text { violation in } \\
\text { all ran- } \\
\text { domised pa- } \\
\text { tients }\end{array}$ & Details & Reference \\
\hline $\begin{array}{l}\text { Inclusion } \\
\text { criteria: } \\
\text { diagnosis of } \\
\text { re- } \\
\text { lapsing mul- } \\
\text { tiple sclero- } \\
\text { sis according } \\
\text { to McDon- } \\
\text { ald criteria }\end{array}$ & 9 & 9 & 4 & 4 & 13 & $13(1.4 \%)$ & $\begin{array}{l}\text { These pa- } \\
\text { tients only } \\
\text { satisfied CIS } \\
\text { criteria }\end{array}$ & $\begin{array}{l}\text { Pol- } \\
\text { man } 2006 \\
\text { AFFIRM } \\
2006\end{array}$ \\
\hline
\end{tabular}


Table 3. Protocol violations in AFFIRM trial (Continued)

\begin{tabular}{|c|c|c|c|c|c|c|c|c|}
\hline $\begin{array}{l}\text { Inclu- } \\
\text { sion criteria: } \\
\text { at least one } \\
\text { med- } \\
\text { ically docu- } \\
\text { mented re- } \\
\text { lapse within } \\
12 \text { months } \\
\text { before ran- } \\
\text { domisation }\end{array}$ & 6 & $6(1 \%)$ & 6 & $6(2 \%)$ & 12 & $12(1.3 \%)$ & $\begin{array}{l}\text { No re- } \\
\text { lapse in pre- } \\
\text { vious year }\end{array}$ & $\begin{array}{l}\text { Pol- } \\
\text { man } 2006 \\
\text { AFFIRM } \\
2006\end{array}$ \\
\hline $\begin{array}{l}\text { Prohibited } \\
\text { concomi- } \\
\text { tant medica- } \\
\text { tion }\end{array}$ & 29 & $22(3.5 \%)$ & 17 & $11(3.5 \%)$ & 46 & $33(3.5 \%)$ & $\begin{array}{l}\text { Only data } \\
\text { from the } \\
\text { first year of } \\
\text { study is re- } \\
\text { ported. Data } \\
\text { for all the } \\
\text { duration of } \\
\text { the trial is } \\
\text { not available } \\
\text { Med- } \\
\text { ications pro- } \\
\text { hibited: cy- } \\
\text { clophospha- } \\
\text { mide, mi- } \\
\text { toxantrone } \\
\text { IFNß, } \\
\text { GA, cy- } \\
\text { closporine, } \\
\text { azathio- } \\
\text { prine, } \\
\text { methotrex- } \\
\text { ate, intra- } \\
\text { venous im- } \\
\text { mune glob- } \\
\text { ulin, experi- } \\
\text { mental } \\
\text { drugs }\end{array}$ & $\begin{array}{l}\text { Center for } \\
\text { drug eval- } \\
\text { uation and } \\
\text { research. } \\
\text { Medical } \\
\text { Review. } \\
\text { Novem- } \\
\text { ber 23, } \\
2004-\text { Drug } \\
\text { Approval } \\
\text { Package } \\
\text { - http:// } \\
\text { www.accessdata.fda.gov/ } \\
\text { drugsatfda docs/ } \\
\text { nda/2004/ } \\
\text { 125104s000 Natalizumab.cfm }\end{array}$ \\
\hline $\begin{array}{l}\text { Other eligi- } \\
\text { bility criteria }\end{array}$ & 58 & $46(7.3 \%)$ & 27 & $21(6.7 \%)$ & 85 & $67(7.1 \%)$ & $\begin{array}{l}\text { Only data } \\
\text { from the } \\
\text { first year of } \\
\text { study is re- } \\
\text { ported. Data } \\
\text { for all the } \\
\text { duration of } \\
\text { the trial is } \\
\text { not available }\end{array}$ & $\begin{array}{l}\text { Center for } \\
\text { drug eval- } \\
\text { uation and } \\
\text { research. } \\
\text { Medical } \\
\text { Review } \\
\text { November } \\
23, \quad 2004 \\
-\quad \text { Drug }\end{array}$ \\
\hline
\end{tabular}


Table 3. Protocol violations in AFFIRM trial (Continued)

No other de- Approval

tail is avail- Package

able.

- http://

www.accessdata.fda.gov/

drugsatfda docs/

nda/2004/

125104s000 Natalizumab.cfm

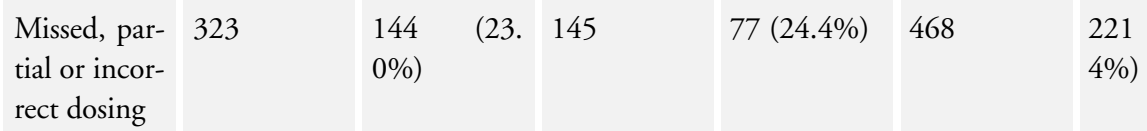

221
$4 \%)$

(23. Only data Center for

from the drug eval-

first year of uation and

study is re- research.

ported. Data Medical

for all the Review.

duration of November

the trial is 23, 2004

not available - Drug

No other de- Approval

tail is avail- Package

able.

- http://

www.accessdata.fda.gov/

drugsatfda docs/

nda/2004/

125104s000 Natalizumab.cfm

\begin{tabular}{|c|c|c|c|c|c|c|c|c|c|}
\hline $\begin{array}{l}\text { Effi- } \\
\text { cacy evalua- } \\
\text { tion not per- } \\
\text { formed or } \\
\text { not valid }\end{array}$ & 104 & $73(11.6 \%)$ & 60 & $45(14.3 \%)$ & 164 & $\begin{array}{l}118 \\
5 \%)\end{array}$ & (12. & $\begin{array}{l}\text { Only data } \\
\text { from the } \\
\text { first year of } \\
\text { study is re- } \\
\text { ported. Data } \\
\text { for all the } \\
\text { duration of } \\
\text { the trial is } \\
\text { not available } \\
\text { No other de- } \\
\text { tail is avail- } \\
\text { able. }\end{array}$ & $\begin{array}{l}\text { Center for } \\
\text { drug eval- } \\
\text { uation and } \\
\text { research. } \\
\text { Medical } \\
\text { Review. } \\
\text { November } \\
\text { 23, } 2004 \\
\text { - Drug } \\
\text { Approval } \\
\text { Package } \\
\text { - http:// } \\
\text { www.accessda } \\
\text { drugsatfda do } \\
\text { nda/2004/ } \\
\text { 125104s000 }\end{array}$ \\
\hline $\begin{array}{l}\text { Safety evalu- } \\
\text { ation not } \\
\text { performed } \\
\text { or not valid }\end{array}$ & 162 & $\begin{array}{l}103 \\
4 \%)\end{array}$ & 95 & 53 (16.8\%) & 257 & $\begin{array}{l}156 \\
6 \%)\end{array}$ & & $\begin{array}{l}\text { Only data } \\
\text { from the } \\
\text { first year of } \\
\text { study is re- } \\
\text { ported. Data } \\
\text { for all the } \\
\text { duration of }\end{array}$ & $\begin{array}{l}\text { Center for } \\
\text { drug eval- } \\
\text { uation and } \\
\text { research. } \\
\text { Medical } \\
\text { Review. } \\
\text { November }\end{array}$ \\
\hline
\end{tabular}

Natalizumab for relapsing remitting multiple sclerosis (Review) 
Table 3. Protocol violations in AFFIRM trial (Continued)

\begin{tabular}{|c|c|c|c|c|c|c|c|c|}
\hline & & & & & & & $\begin{array}{l}\text { the trial is } \\
\text { not available } \\
\text { No other de- } \\
\text { tail is avail- } \\
\text { able. }\end{array}$ & $\begin{array}{l}23, \quad 2004 \\
-\quad \text { Drug } \\
\text { Approval } \\
\text { Package } \\
-\quad \text { http:// } \\
\text { www.accessdata.fda.gov/ } \\
\text { drugsatfda docs/ } \\
\text { nda/2004/ } \\
125104 s 000 \cdot \text { Natalizumab.cfm }\end{array}$ \\
\hline $\begin{array}{l}\text { Outside ac- } \\
\text { ceptable } \\
\text { visit window }\end{array}$ & 1239 & $\begin{array}{l}406 \\
8 \%)\end{array}$ & 692 & $218(69.2)$ & 1931 & $\begin{array}{l}624 \quad(66 . \\
2 \%)\end{array}$ & $\begin{array}{l}\text { Only data } \\
\text { from the } \\
\text { first year of } \\
\text { study are re- } \\
\text { ported. Data } \\
\text { for all the } \\
\text { duration of } \\
\text { the trial are } \\
\text { not available } \\
\text { No other de- } \\
\text { tail is avail- } \\
\text { able. }\end{array}$ & $\begin{array}{l}\text { Center for } \\
\text { drug eval- } \\
\text { uation and } \\
\text { research. } \\
\text { Medical } \\
\text { Review. } \\
\text { November } \\
23, \quad 2004 \\
\text { - Drug } \\
\text { Approval } \\
\text { Package } \\
\text { - http:// } \\
\text { www.accessdata.fda.gov/ } \\
\text { drugsatfda docs/ } \\
\text { nda/2004/ } \\
\text { 125104s000 Natalizumab.cfm }\end{array}$ \\
\hline $\begin{array}{l}\text { Missed } \\
\text { study visit }\end{array}$ & 38 & $25(4.0 \%)$ & 22 & $13(4.1 \%)$ & 60 & $38(4.0 \%)$ & $\begin{array}{l}\text { Only data } \\
\text { from the } \\
\text { first year of } \\
\text { study is re- } \\
\text { ported. Data } \\
\text { for all the } \\
\text { duration of } \\
\text { the trial is } \\
\text { not available } \\
\text { No other de- } \\
\text { tail is avail- } \\
\text { able. }\end{array}$ & $\begin{array}{l}\text { Center for } \\
\text { drug eval- } \\
\text { uation and } \\
\text { research. } \\
\text { Medical } \\
\text { Review. } \\
\text { November } \\
23 \text {, } 2004 \\
\text { - Drug } \\
\text { Approval } \\
\text { Package } \\
\text { - http:// } \\
\text { www.accessdata.fda.gov/ } \\
\text { drugsatfda docs/ } \\
\text { nda/2004/ } \\
\text { 125104s000 Natalizumab.cfm }\end{array}$ \\
\hline $\begin{array}{l}\text { Discontinu- } \\
\text { a- } \\
\text { tion of study } \\
\text { treatment in } \\
\text { patients who } \\
\text { had HSRs }\end{array}$ & 2 & 2 & 0 & 0 & 2 & $2(\prec 1 \%)$ & $\begin{array}{l}\text { Two NTZ } \\
\text { patients } \\
\text { were } \\
\text { redosed after } \\
\text { experienc- }\end{array}$ & $\begin{array}{l}\text { Phillips } \\
2006 \\
\text { AFFIRM } \\
2006\end{array}$ \\
\hline
\end{tabular}


Table 3. Protocol violations in AFFIRM trial (Continued)

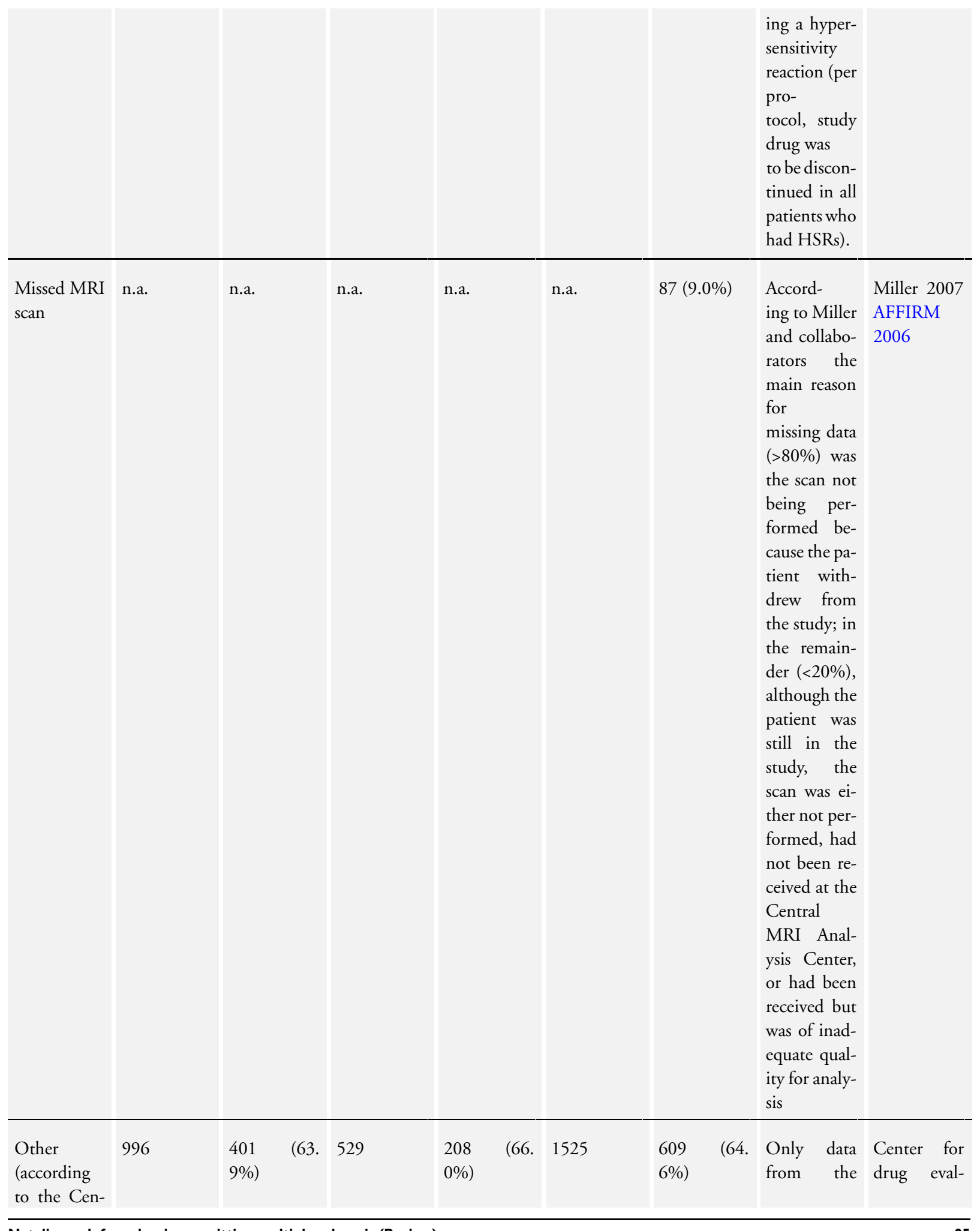

Natalizumab for relapsing remitting multiple sclerosis (Review)

Copyright @ 201 I The Cochrane Collaboration. Published by John Wiley \& Sons, Ltd. 
Table 3. Protocol violations in AFFIRM trial (Continued)

\begin{tabular}{|c|c|c|c|c|c|c|c|c|c|c|}
\hline $\begin{array}{l}\text { ter for } \\
\text { drug evalua- } \\
\text { tion and re- } \\
\text { search) }\end{array}$ & & & & & & & & & $\begin{array}{l}\text { first year of } \\
\text { study is re- } \\
\text { ported. Data } \\
\text { for all the } \\
\text { duration of } \\
\text { the trial is } \\
\text { not available } \\
\text { No other de- } \\
\text { tail is avail- } \\
\text { able. }\end{array}$ & $\begin{array}{l}\text { uation and } \\
\text { research. } \\
\text { Medical } \\
\text { Review. } \\
\text { November } \\
23, \quad 2004 \\
-\quad \text { Drug } \\
\text { Approval } \\
\text { Package } \\
\text { - http:// } \\
\text { www.accessdata.fda.gov/ } \\
\text { drugsatfda docs/ } \\
\text { nda/2004/ } \\
\text { 125104s000 } \text { Natalizumab.cfm }\end{array}$ \\
\hline
\end{tabular}

Table 4. Protocol violations in GLANCE trial

\begin{tabular}{|c|c|c|c|c|c|c|c|c|}
\hline $\begin{array}{l}\text { Type of pro- } \\
\text { tocol viola- } \\
\text { tion }\end{array}$ & $\begin{array}{l}\mathrm{N} \text { of } \\
\text { violations in } \\
\text { NTZ group }\end{array}$ & $\begin{array}{l}\mathrm{N} \text { of } \\
\text { patients } \\
\text { with at least } \\
\text { one protocol } \\
\text { violation in } \\
\text { NTZ group }\end{array}$ & $\begin{array}{l}\mathrm{N} \text { of viola- } \\
\text { tions in con- } \\
\text { trol group }\end{array}$ & $\begin{array}{l}\mathrm{N} \\
\text { patients } \\
\text { with at least } \\
\text { one protocol } \\
\text { viola- } \\
\text { tion in con- } \\
\text { trol group }\end{array}$ & $\begin{array}{l}\text { Total } \mathrm{N} \text { of } \\
\text { violations in } \\
\text { all ran- } \\
\text { domised pa- } \\
\text { tients }\end{array}$ & $\begin{array}{l}\text { Total } \mathrm{N} \text { of } \\
\text { patients } \\
\text { with at least } \\
\text { one protocol } \\
\text { violation in } \\
\text { all ran- } \\
\text { domised pa- } \\
\text { tients }\end{array}$ & Details & Reference \\
\hline $\begin{array}{l}\text { Incusion cri- } \\
\text { teria: at least } \\
\text { one med- } \\
\text { ically docu- } \\
\text { mented re- } \\
\text { lapse within }\end{array}$ & n.a. & n.a. & n.a. & n.a. & n.a. & n.a. & $\begin{array}{l}\text { the min- } \\
\text { imum of } \mathrm{N} \\
\text { of relapses in } \\
\text { previous } 12 \\
\text { mo is } 0 \text { In }\end{array}$ & $\begin{array}{l}\text { Good- } \\
\text { man 2009 } \\
\text { GLANCE } \\
2009\end{array}$ \\
\hline
\end{tabular}


Table 4. Protocol violations in GLANCE trial (Continued)

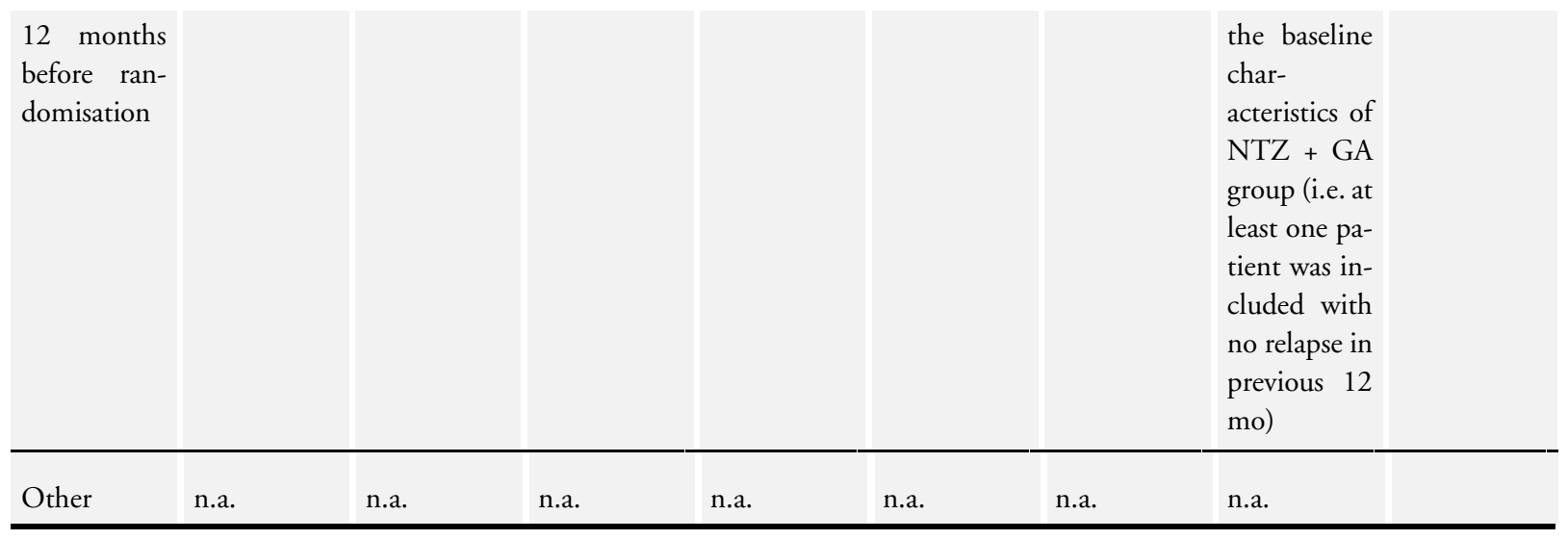

Table 5. Protocol violations in SENTINEL trial

\begin{tabular}{|c|c|c|c|c|c|c|c|c|}
\hline $\begin{array}{l}\text { Type of pro- } \\
\text { tocol viola- } \\
\text { tion }\end{array}$ & $\begin{array}{l}\mathrm{N} \text { of } \\
\text { violations in } \\
\text { NTZ group }\end{array}$ & $\begin{array}{l}\mathrm{N} \text { of } \\
\text { patients } \\
\text { with at least } \\
\text { one protocol } \\
\text { violation in } \\
\text { NTZ group }\end{array}$ & $\begin{array}{l}\mathrm{N} \text { of viola- } \\
\text { tions in con- } \\
\text { trol group }\end{array}$ & $\begin{array}{l}\mathrm{N} \text { of } \\
\text { patients } \\
\text { with at least } \\
\text { one protocol } \\
\text { viola- } \\
\text { tion in con- } \\
\text { trol group }\end{array}$ & $\begin{array}{l}\text { Total } \mathrm{N} \text { of } \\
\text { violations in } \\
\text { all ran- } \\
\text { domised pa- } \\
\text { tients }\end{array}$ & $\begin{array}{l}\text { Total } \mathrm{N} \text { of } \\
\text { patients } \\
\text { with at least } \\
\text { one protocol } \\
\text { violation in } \\
\text { all ran- } \\
\text { domised pa- } \\
\text { tients }\end{array}$ & Details & Reference \\
\hline $\begin{array}{l}\text { Inclu- } \\
\text { sion criteria: } \\
\text { at least one } \\
\text { med- } \\
\text { ically docu- } \\
\text { mented re- } \\
\text { lapse within } \\
12 \text { months } \\
\text { before ran- } \\
\text { domisation }\end{array}$ & 0 & 0 & 1 & $1(\prec 1 \%)$ & 1 & $1(\prec 1 \%)$ & $\begin{array}{l}\text { no relapse in } \\
\text { past } 12 \text { mo. }\end{array}$ & $\begin{array}{l}\text { Rudick } \\
2006 \\
\text { SENTINEL } \\
2006\end{array}$ \\
\hline $\begin{array}{l}\text { Prohibited } \\
\text { concomi- } \\
\text { tant medica- } \\
\text { tion }\end{array}$ & 69 & $55(9.3 \%)$ & 72 & $53(9.1 \%)$ & 141 & $108(9.2 \%)$ & $\begin{array}{l}\text { Only data } \\
\text { from the } \\
\text { first year of } \\
\text { study is re- } \\
\text { ported. Data } \\
\text { for all the } \\
\text { duration of } \\
\text { the trial is } \\
\text { not available } \\
\text { Medications } \\
\text { prohib- } \\
\text { ited: any ap- }\end{array}$ & $\begin{array}{l}\text { Center for } \\
\text { drug eval- } \\
\text { uation and } \\
\text { research. } \\
\text { Medical } \\
\text { Review. } \\
\text { November } \\
23, \quad 2004 \\
\text { Approval } \\
\text { Appro } \\
\text { Package }\end{array}$ \\
\hline
\end{tabular}


Table 5. Protocol violations in SENTINEL trial (Continued)

\begin{tabular}{|c|c|c|c|c|c|c|c|c|c|}
\hline & & & & & & & & $\begin{array}{l}\text { proved dis- } \\
\text { ease modify- } \\
\text { ing therapy } \\
\text { other than } \\
\text { IFNß-1a im } \\
\text { once a week, } \\
\text { experimen- } \\
\text { tal drugs }\end{array}$ & $\begin{array}{l}\text { - } \quad \text { http:// } \\
\text { www.accessdata.fda.gov/ } \\
\text { drugsatfda } \cdot \text { docs/ } \\
\text { nda/2004/ } \\
125104 \text { s000 Natalizumab.cfm }\end{array}$ \\
\hline $\begin{array}{l}\text { Other eligi- } \\
\text { bility criteria }\end{array}$ & 88 & $70(11.9 \%)$ & 87 & $66(11.3 \%)$ & 175 & $\begin{array}{l}136 \\
6 \%)\end{array}$ & (11. & $\begin{array}{l}\text { Only data } \\
\text { from the } \\
\text { first year of } \\
\text { study is re- } \\
\text { ported. Data } \\
\text { for all the } \\
\text { duration of } \\
\text { the trial is } \\
\text { not available } \\
\text { No other de- } \\
\text { tail is avail- } \\
\text { able. }\end{array}$ & $\begin{array}{l}\text { Center for } \\
\text { drug eval- } \\
\text { uation and } \\
\text { research. } \\
\text { Medical } \\
\text { Review. } \\
\text { November } \\
23, \quad 2004 \\
\text { - Drug } \\
\text { Approval } \\
\text { Package } \\
\text { - http:// } \\
\text { www.accessdata.fda.gov/ } \\
\text { drugsatfda } \text { docs/ } \\
\text { nda/2004/ } \\
\text { 125104s000 Natalizumab.cfm }\end{array}$ \\
\hline $\begin{array}{l}\text { Missed, par- } \\
\text { tial or incor- } \\
\text { rect dosing }\end{array}$ & 868 & $\begin{array}{l}306 \\
0 \%)\end{array}$ & 918 & $\begin{array}{l}310 \quad(53 . \\
3 \%)\end{array}$ & 1786 & $\begin{array}{l}616 \\
6 \%)\end{array}$ & (52. & $\begin{array}{l}\text { Only data } \\
\text { from the } \\
\text { first year of } \\
\text { study is re- } \\
\text { ported. Data } \\
\text { for all the } \\
\text { duration of } \\
\text { the trial is } \\
\text { not available } \\
\text { No other de- } \\
\text { tail is avail- } \\
\text { able. }\end{array}$ & $\begin{array}{l}\text { Center for } \\
\text { drug eval- } \\
\text { uation and } \\
\text { research. } \\
\text { Medical } \\
\text { Review. } \\
\text { November } \\
23 \text {, } 2004 \\
\text { Approval } \\
\text { Package } \\
\text { - http:// } \\
\text { www.accessdata.fda.gov/ } \\
\text { drugsatfda } \text { docs/ } \\
\text { nda/2004/ } \\
\text { 125104s000 } \text { Natalizumab.cfm }\end{array}$ \\
\hline $\begin{array}{l}\text { Ef- } \\
\text { ficay evalua- } \\
\text { tion not per- } \\
\text { formed or } \\
\text { not valid }\end{array}$ & 189 & $\begin{array}{l}113 \\
2 \%)\end{array}$ & 197 & $\begin{array}{l}107 \\
4 \%)\end{array}$ & 386 & $\begin{array}{l}220 \\
8 \%)\end{array}$ & (18. & $\begin{array}{l}\text { Only data } \\
\text { from the } \\
\text { first year of } \\
\text { study is re- } \\
\text { ported. Data } \\
\text { for all the }\end{array}$ & $\begin{array}{l}\text { Center for } \\
\text { drug eval- } \\
\text { uation and } \\
\text { research. } \\
\text { Medical } \\
\text { Review. }\end{array}$ \\
\hline
\end{tabular}


Table 5. Protocol violations in SENTINEL trial (Continued)

\begin{tabular}{|c|c|c|c|c|c|c|c|c|}
\hline & & & & & & & $\begin{array}{l}\text { duration of } \\
\text { the trial is } \\
\text { not available } \\
\text { No other de- } \\
\text { tail is avail- } \\
\text { able. }\end{array}$ & $\begin{array}{l}\text { November } \\
23, \quad 2004 \\
-\quad \text { Drug } \\
\text { Approval } \\
\text { Package } \\
\text { - http:// } \\
\text { www.accessdata.fda.gov/ } \\
\text { drugsatfda docs/ } \\
\text { nda/2004/ } \\
\text { 125104s000 } \text { Natalizumab.cfm }\end{array}$ \\
\hline $\begin{array}{l}\text { Safety evalu- } \\
\text { ation not } \\
\text { performed } \\
\text { or not valid }\end{array}$ & 185 & $\begin{array}{l}101 \\
1 \%)\end{array}$ & 213 & $\begin{array}{l}120 \\
6 \%)\end{array}$ & 398 & $\begin{array}{l}221 \\
9 \%)\end{array}$ & $\begin{array}{l}\text { Only data } \\
\text { from the } \\
\text { first year of } \\
\text { study is re- } \\
\text { ported. Data } \\
\text { for all the } \\
\text { duration of } \\
\text { the trial is } \\
\text { not available } \\
\text { No other de- } \\
\text { tail is avail- } \\
\text { able. }\end{array}$ & $\begin{array}{l}\text { Center for } \\
\text { drug eval- } \\
\text { uation and } \\
\text { research. } \\
\text { Medical } \\
\text { Review. } \\
\text { November } \\
23 \text {, } \quad 2004 \\
-\quad \text { Drug } \\
\text { Approval } \\
\text { Package } \\
\text { - http:// } \\
\text { www.accessdata.fda.gov/ } \\
\text { drugsatfda } \text { docs/ } \\
\text { nda/2004/ } \\
\text { 125104s000 } \text { Natalizumab.cfm }\end{array}$ \\
\hline $\begin{array}{l}\text { Outside ac- } \\
\text { ceptable } \\
\text { visit window }\end{array}$ & 1423 & $\begin{array}{l}418 \\
0 \%)\end{array}$ & 1504 & $\begin{array}{l}430 \\
9 \%)\end{array}$ & 2927 & $\begin{array}{l}848 \\
4 \%)\end{array}$ & $\begin{array}{l}\text { Only data } \\
\text { from the } \\
\text { first year of } \\
\text { study is re- } \\
\text { ported. Data } \\
\text { for all the } \\
\text { duration of } \\
\text { the trial is } \\
\text { not available } \\
\text { No other de- } \\
\text { tail is avail- } \\
\text { able. }\end{array}$ & $\begin{array}{l}\text { Center for } \\
\text { drug eval- } \\
\text { uation and } \\
\text { research. } \\
\text { Medical } \\
\text { Review. } \\
\text { November } \\
23, \quad 2004 \\
-\quad \text { Drug } \\
\text { Approval } \\
\text { Package } \\
\text { - http:// } \\
\text { www.accessdata.fda.gov/ } \\
\text { drugsatfda } \text { docs/ } \\
\text { nda/2004/ } \\
\text { 125104s000 } \text { Natalizumab.cfm }\end{array}$ \\
\hline $\begin{array}{l}\text { Missed } \\
\text { study visit }\end{array}$ & 39 & $29(4.9 \%)$ & 54 & $39(6.7 \%)$ & 93 & $68(5.8 \%)$ & $\begin{array}{l}\text { Only data } \\
\text { from the } \\
\text { first year of } \\
\text { study is re- }\end{array}$ & $\begin{array}{l}\text { Center for } \\
\text { drug eval- } \\
\text { uation and } \\
\text { research. }\end{array}$ \\
\hline
\end{tabular}


Table 5. Protocol violations in SENTINEL trial (Continued)

\begin{tabular}{|c|c|c|c|c|c|c|c|c|}
\hline & & & & & & & $\begin{array}{l}\text { ported. Data } \\
\text { for all the } \\
\text { duration of } \\
\text { the trial is } \\
\text { not available } \\
\text { No other de- } \\
\text { tail is avail- } \\
\text { able. }\end{array}$ & $\begin{array}{l}\text { Medical } \\
\text { Review. } \\
\text { November } \\
23, \quad 2004 \\
-\quad \text { Drug } \\
\text { Approval } \\
\text { Package } \\
\text { - http:// } \\
\text { www.accessdata.fda.gov/ } \\
\text { drugsatfda docs/ } \\
\text { nda/2004/ } \\
\text { 125104s000 } \text { Natalizumab.cfm }\end{array}$ \\
\hline $\begin{array}{l}\text { Other } \\
\text { (according } \\
\text { to the Cen- } \\
\text { ter for } \\
\text { drug evalua- } \\
\text { tion and re- } \\
\text { search) }\end{array}$ & 1639 & $\begin{array}{l}411 \\
8 \%)\end{array}$ & 1799 & $\begin{array}{l}425 \\
0 \%)\end{array}$ & 3438 & $\begin{array}{l}836 \\
4 \%)\end{array}$ & $\begin{array}{l}\text { Only data } \\
\text { from the } \\
\text { first year of } \\
\text { study is re- } \\
\text { ported. Data } \\
\text { for all the } \\
\text { duration of } \\
\text { the trial is } \\
\text { not available } \\
\text { No other de- } \\
\text { tail is avail- } \\
\text { able. }\end{array}$ & $\begin{array}{l}\text { Center for } \\
\text { drug eval- } \\
\text { uation and } \\
\text { research. } \\
\text { Medical } \\
\text { Review. } \\
\text { November } \\
23, \quad 2004 \\
\text { - Drug } \\
\text { Approval } \\
\text { Package } \\
\text { - http:// } \\
\text { www.accessdata.fda.gov/ } \\
\text { drugsatfda } \text { docs/ } \\
\text { nda/2004/ } \\
\text { 125104s } 000 \cdot \text { Natalizumab.cfm }\end{array}$ \\
\hline $\begin{array}{l}\text { All vi- } \\
\text { olations ac- } \\
\text { cording } \\
\text { to the Cen- } \\
\text { ter for } \\
\text { drug evalua- } \\
\text { tion and re- } \\
\text { search }\end{array}$ & 4500 & $\begin{array}{l}569 \\
6 \%)\end{array}$ & 4855 & $\begin{array}{l}568 \\
6 \%)\end{array}$ & 9355 & $\begin{array}{l}1137 \\
1 \%)\end{array}$ & & $\begin{array}{l}\text { Center for } \\
\text { drug eval- } \\
\text { uation and } \\
\text { research. } \\
\text { Medical } \\
\text { Review. } \\
\text { November } \\
23 \text {, } 2004 \\
-\quad \text { Drug } \\
\text { Approval } \\
\text { Package } \\
\text { - http:// } \\
\text { www.accessdata.fda.gov/ } \\
\text { drugsatfda docs/ } \\
\text { nda/2004/ } \\
\text { 125104s000 } \text { Natalizumab.cfm }\end{array}$ \\
\hline
\end{tabular}


Table 6. Other trials sponsored by the Pharmaceutical Industry

\begin{tabular}{|c|c|c|c|c|c|c|c|c|c|c|}
\hline $\begin{array}{l}\text { Study } \\
\text { label }\end{array}$ & Phase & Aims & $\begin{array}{l}\text { Popula- } \\
\text { tion }\end{array}$ & Design & $\begin{array}{l}\text { Dose regi- } \\
\text { men }\end{array}$ & $\begin{array}{l}\mathrm{N} \text { of par- } \\
\text { ticipants }\end{array}$ & Duration & $\begin{array}{l}\text { Planned } \\
\mathrm{N} \text { of doses }\end{array}$ & $\begin{array}{l}\text { Outcome } \\
\text { measures }\end{array}$ & $\begin{array}{l}\text { Main ref- } \\
\text { erences }\end{array}$ \\
\hline 200 & 1 & $\begin{array}{l}\text { Safety } \\
\text { Tolerabil- } \\
\text { ity }\end{array}$ & $\begin{array}{l}\text { RRMS } \\
\text { and } \\
\text { SPMS } \\
\text { subjects }\end{array}$ & $\begin{array}{l}\text { Ran- } \\
\text { domised, } \\
\text { Double- } \\
\text { blind, } \\
\text { Placebo- } \\
\text { con- } \\
\text { trolled, } \\
\text { Dose- } \\
\text { escalation }\end{array}$ & $\begin{array}{l}0 . \\
03 \quad(\mathrm{n}=3) \\
-0.1 \quad(\mathrm{n}= \\
\text { 3) } 0.3(\mathrm{n}= \\
\text { 3) } 1.0(\mathrm{n}= \\
\text { 6) } 3.0(\mathrm{n}= \\
\text { 6) } \mathrm{mg} / \mathrm{Kg} \text {; } \\
\text { (placebo } \\
\mathrm{n}=7)\end{array}$ & 28 & n.a. & 1 & $\begin{array}{l}\text { Safety } \\
\text { Tolerabil- } \\
\text { ity }\end{array}$ & $\begin{array}{l}\text { Shere- } \\
\text { mata } \\
1999\end{array}$ \\
\hline 221 & 1 & $\begin{array}{l}\text { Safety } \\
\text { Pharma- } \\
\text { cokinetics } \\
\text { Pharma- } \\
\text { codynam- } \\
\text { ics }\end{array}$ & $\begin{array}{l}\text { RRMS } \\
\text { and } \\
\text { SPMS } \\
\text { subjects }\end{array}$ & $\begin{array}{l}\text { Ran- } \\
\text { domised, } \\
\text { Placebo- } \\
\text { controlled }\end{array}$ & $\begin{array}{l}1-3-6 \mathrm{mg} / \\
\mathrm{Kg}\end{array}$ & 39 & n.a. & 1 & $\begin{array}{l}\text { Safety } \\
\text { Pharma- } \\
\text { codynam- } \\
\text { ics }\end{array}$ & $\begin{array}{l}\text { Center } \\
\text { for drug } \\
\text { evalua- } \\
\text { tion and } \\
\text { research. } \\
\text { Medical } \\
\text { Review } \\
\text { - Drug } \\
\text { Approval } \\
\text { Package } \\
\text { - http:// } \\
\text { www.accessdata.fda.gov/ } \\
\text { drugsatfda } \text { docs/ } \\
\text { nda/ } \\
2004 / \\
125104 \text { s000 Natalizumab.cfm } \\
\text { study } \\
\text { quoted } \\
\text { by Rudick } \\
2004\end{array}$ \\
\hline 224 & 1 & $\begin{array}{l}\text { Safety } \\
\text { Pharma- } \\
\text { cokinetics } \\
\text { Interac- } \\
\text { tion with } \\
\text { IFNB-1a }\end{array}$ & $\begin{array}{l}\text { RRMS } \\
\text { subjects } \\
\text { treated } \\
\text { with in- } \\
\text { tramuscu- } \\
\text { lar IFNß- } \\
\text { la }\end{array}$ & $\begin{array}{l}\text { Open la- } \\
\text { bel }\end{array}$ & $\begin{array}{l}3 \quad(n=15) \\
-6(n=23) \\
m g / K g\end{array}$ & 38 & n.a. & 1 & $\begin{array}{l}\text { Safety } \\
\text { Pharma- } \\
\text { cokinetics }\end{array}$ & $\begin{array}{l}\text { Center } \\
\text { for drug } \\
\text { evalua- } \\
\text { tion and } \\
\text { research. } \\
\text { Medical } \\
\text { Review } \\
\text { - Drug } \\
\text { Approval } \\
\text { Package } \\
\text { - http:// } \\
\text { www.accessdata.fda.gov/ } \\
\text { drugsatfda'docs/ }\end{array}$ \\
\hline
\end{tabular}


Table 6. Other trials sponsored by the Pharmaceutical Industry (Continued)

\begin{tabular}{|c|c|c|c|c|c|c|c|c|c|c|}
\hline & & & & & & & & & & $\begin{array}{l}\text { nda/ } \\
2004 / \\
125104 \mathrm{~s} 000 \\
\text { Vollmer } \\
2004\end{array}$ \\
\hline $\begin{array}{l}201 \\
\text { UK Ante- } \\
\text { gren } \\
\text { Study }\end{array}$ & 2 & $\begin{array}{l}\text { Prelim- } \\
\text { inary effi- } \\
\text { cacy }\end{array}$ & $\begin{array}{l}\text { RRMS } \\
\text { and } \\
\text { SPMS } \\
\text { subjects }\end{array}$ & $\begin{array}{l}\text { Ran- } \\
\text { domised, } \\
\text { Double- } \\
\text { blind, } \\
\text { Placebo- } \\
\text { controlled }\end{array}$ & $3 \mathrm{mg} / \mathrm{Kg}$ & $\begin{array}{l}72 \\
\text { (placebo } \\
\mathrm{n}=35 \text { ) }\end{array}$ & $24 \mathrm{wks}$ & 2 & $\begin{array}{l}\text { MRI pa- } \\
\text { rameters }\end{array}$ & $\begin{array}{l}\text { UK } \\
\text { Antegren } \\
\text { Study } \\
1999\end{array}$ \\
\hline $\begin{array}{l}202 \\
\text { Natal- } \\
\text { izumab } \\
\text { Mul- } \\
\text { tiple Scle- } \\
\text { rosis Trial }\end{array}$ & 2 & $\begin{array}{l}\text { Prelim- } \\
\text { inary effi- } \\
\text { cacy (on } \\
\text { relapse) }\end{array}$ & $\begin{array}{l}\text { RRMS } \\
\text { and } \\
\text { SPMS } \\
\text { subjects in } \\
\text { relapse }\end{array}$ & $\begin{array}{l}\text { Ran- } \\
\text { domised, } \\
\text { Double- } \\
\text { blind, } \\
\text { Placebo- } \\
\text { controlled }\end{array}$ & $\begin{array}{ll}1-3 & \mathrm{mg} / \\
\mathrm{Kg} & \end{array}$ & 180 & 14 wks & 1 & $\begin{array}{l}\text { MRI pa- } \\
\text { rameters } \\
\text { EDSS } \\
\text { Scripp } \\
\text { Neuro- } \\
\text { logic Rat- } \\
\text { ing Scale } \\
\text { Patient's } \\
\text { own } \\
\text { assess- } \\
\text { ment of } \\
\text { well-being }\end{array}$ & $\begin{array}{l}\text { O'Connor } \\
2004\end{array}$ \\
\hline
\end{tabular}

\section{A P P E N D I CES}

\section{Appendix I. CENTRAL search strategy}

\#1MeSH descriptor Multiple Sclerosis explode all trees \#2MeSH descriptor Demyelinating Diseases, this term only \#3MeSH descriptor Myelitis, Transverse, this term only \#4MeSH descriptor Optic Neuritis explode all trees \#5MeSH descriptor Encephalomyelitis, Acute Disseminated, this term only \#6(multiple sclerosis)

\#7(demyelinating disease*)

\#8(transverse myelitis)

\#9(neuromyelitis optica)

\#10(optic neuritis)

\#11(encephalomyelitis acute disseminated)

$\# 12$ (devic)

\#13(\#1 OR \#1 OR \#3 OR \#4 OR \#5 OR \#6 OR \#7 OR \#8 OR \#9 OR \#10 OR \#11 OR \#12)

\#14natalizumab OR antegren OR tysabri \#15(\#13 AND \#14)

Natalizumab for relapsing remitting multiple sclerosis (Review) 


\section{Appendix 2. MEDLINE (PubMed) search strategy}

((natalizumab OR antegren OR tysabri))) AND (((“"Multiple Sclerosis”[mh]) OR (“Myelitis, Transverse”[mh:noexp]) OR (“Demyelinating Diseases”[mh:noexp]) OR (“Encephalomyelitis, Acute Disseminated”[mh:noexp]) OR (“Optic Neuritis”[mh])) OR (((“multiple sclerosis") OR (“neuromyelitis optica”) OR (“transverse myelitis”) OR (encephalomyelitis) OR (devic) OR (“optic neuritis”)) OR (“demyelinating disease*”) OR (“acute disseminated encephalomyelitis"))) AND (((randomized controlled trial[pt]) OR (controlled clinical trial[pt]) OR (randomized[tiab]) OR (placebo[tiab]) OR (drug therapy[sh]) OR (randomly[tiab]) OR (trial[tiab]) OR (groups[tiab])) NOT ((animals[mh]) NOT ((animals[mh]) AND (human $[\mathrm{mh}]))))$ )

\section{Appendix 3. EMBASE search strategy}

(('encephalomyelitis'/exp) OR ('demyelinating disease'/exp) OR ('multiple sclerosis'/exp) OR ('myelooptic neuropathy'/exp) OR ('multiple sclerosis':ti,ab) OR ('neuromyelitis optica':ab,ti) OR (encephalomyelitis:ab,ti) OR (devic:ti,ab)) AND (('crossover procedure'/exp) OR ('double blind procedure'/exp) OR ('clinical trial'/exp) OR ('controlled clinical trial'/exp) OR ('single blind procedure'/exp) OR ('randomized controlled trial'/exp) OR (random*:ab,ti) OR (factorial*:ab,ti) OR (crossover:ab,ti) OR (cross:ab,ti AND over:ab,ti) OR (placebo:ab,ti) OR ('double blind':ab,ti) OR ('single blind':ab,ti) OR (assign*:ab,ti) OR (allocat*:ab,ti) OR (volunteer*ab,ti))) AND ((('natalizumab'/exp) OR (antegren:ab,ti OR tysabri:ab,ti OR natalizumab:ab,ti))) AND [humans]/lim AND [embase]/lim

\section{Appendix 4. Risk of bias criteria}

\begin{tabular}{|c|c|c|c|}
\hline & Item & Judgment & Description \\
\hline \multirow[t]{3}{*}{1} & $\begin{array}{l}\text { Random sequence generation (selection } \\
\text { bias) }\end{array}$ & low risk & $\begin{array}{l}\text { The investigators describe a random component in the sequence gener- } \\
\text { ation process such as: random number table; computer random num- } \\
\text { ber generator; coin tossing; shuffling cards or envelopes; throwing dice; } \\
\text { drawing of lots; minimization }\end{array}$ \\
\hline & & high risk & $\begin{array}{l}\text { The investigators describe a non-random component in the sequence } \\
\text { generation process such as: odd or even date of birth; date (or day) of } \\
\text { admission; hospital or clinic record number; alternation; judgement of } \\
\text { the clinician; results of a laboratory test or a series of tests; availability } \\
\text { of the intervention }\end{array}$ \\
\hline & & unclear risk & $\begin{array}{l}\text { Insufficient information about the sequence generation process to per- } \\
\text { mit judgement of 'Yes' or 'No' }\end{array}$ \\
\hline \multirow[t]{2}{*}{2} & Allocation concealment (selection bias) & low risk & $\begin{array}{l}\text { Investigators enrolling participants could not foresee assignment be- } \\
\text { cause one of the following, or an equivalent method, was used to con- } \\
\text { ceal allocation: central allocation (including telephone, web-based, and } \\
\text { pharmacy-controlled, randomization); sequentially numbered drug } \\
\text { containers of identical appearance; sequentially numbered, opaque, } \\
\text { sealed envelopes }\end{array}$ \\
\hline & & high risk & $\begin{array}{l}\text { Investigators enrolling participants could possibly foresee assignments } \\
\text { because one of the following method was used: open random allocation } \\
\text { schedule (e.g. a list of random numbers); assignment envelopes without } \\
\text { appropriate safeguards (e.g. if envelopes were unsealed or non opaque }\end{array}$ \\
\hline
\end{tabular}

Natalizumab for relapsing remitting multiple sclerosis (Review)

Copyright @ 2011 The Cochrane Collaboration. Published by John Wiley \& Sons, Ltd. 
or not sequentially numbered); alternation or rotation; date of birth; case record number; any other explicitly unconcealed procedure

unclear risk Insufficient information to permit judgement of 'Yes' or 'No'. This is usually the case if the method of concealment is not described or not described in sufficient detail to allow a definite judgement

3 Blinding of patients, provider, outcome low risk assessor (performance bias and detection bias)

Objective outcomes
Blinding of participants, providers and outcome assessor and unlikely that the blinding could have been broken;

Either participants or providers were not blinded, but outcome assessment was blinded and the non-blinding of others unlikely to introduce bias

No blinding, but the objective outcome measurement are not likely to be influenced by lack of blinding

high risk No blinding or incomplete blinding, and the outcome or outcome measurement is likely to be influenced by lack of blinding;

Blinding of key study participants and personnel attempted, but likely that the blinding could have been broken;

Either participants or outcome assessor were not blinded, and the nonblinding of others likely to introduce bias

unclear risk Insufficient information to permit judgement of 'Yes' or 'No';

4 Blinding of patients, provider, outcome low risk assessor (performance bias and detection bias)

Subjective outcomes
Blinding of participants, providers and outcome assessor and unlikely that the blinding could have been broken;

Either participants or providers were not blinded, but outcome assessment was blinded and the non-blinding of others unlikely to introduce bias

high risk
No blinding or incomplete blinding, and the outcome or outcome measurement is likely to be influenced by lack of blinding;

Blinding of key study participants and personnel attempted, but likely that the blinding could have been broken;

Either participants or outcome assessor were not blinded, and the nonblinding of others likely to introduce bias

unclear risk Insufficient information to permit judgement of 'Yes' or 'No';

5 Incomplete outcome data (attrition bias) low risk for all outcomes except retention in treatment or drop out
No missing outcome data;

Reasons for missing outcome data unlikely to be related to true outcome (for survival data, censoring unlikely to be introducing bias); Missing outcome data balanced in numbers across intervention groups, with similar reasons for missing data across groups;

For dichotomous outcome data, the proportion of missing outcomes compared with observed event risk not enough to have a clinically relevant impact on the intervention effect estimate;

For continuous outcome data, plausible effect size (difference in means 


\begin{tabular}{|c|c|c|c|}
\hline & & & $\begin{array}{l}\text { or standardized difference in means) among missing outcomes not } \\
\text { enough to have a clinically relevant impact on observed effect size; } \\
\text { Missing data have been imputed using appropriate methods } \\
\text { All randomized patients are reported/analyzed in the group they were } \\
\text { allocated to by randomization irrespective of non-compliance and co- } \\
\text { interventions (intention to treat) }\end{array}$ \\
\hline & & high risk & $\begin{array}{l}\text { Reason for missing outcome data likely to be related to true outcome, } \\
\text { with either imbalance in numbers or reasons for missing data across } \\
\text { intervention groups; } \\
\text { For dichotomous outcome data, the proportion of missing outcomes } \\
\text { compared with observed event risk enough to induce clinically relevant } \\
\text { bias in intervention effect estimate; } \\
\text { For continuous outcome data, plausible effect size (difference in means } \\
\text { or standardized difference in means) among missing outcomes enough } \\
\text { to induce clinically relevant bias in observed effect size; } \\
\text { 'As-treated' analysis done with substantial departure of the intervention } \\
\text { received from that assigned at randomization; }\end{array}$ \\
\hline & & unclear risk & $\begin{array}{l}\text { Insufficient reporting of attrition/exclusions to permit judgement of } \\
\text { 'Yes' or 'No' (e.g. number randomized not stated, no reasons for missing } \\
\text { data provided; number of drop out not reported for each group); }\end{array}$ \\
\hline \multirow[t]{5}{*}{6} & Selective reporting & low risk & $\begin{array}{l}\text { The study protocol is available and all of the study's pre-specified (pri- } \\
\text { mary and secondary) outcomes that are of interest in the review have } \\
\text { been reported in the pre-specified way; } \\
\text { The study protocol is not available but it is clear that the published } \\
\text { reports include all expected outcomes, including those that were pre- } \\
\text { specified (convincing text of this nature may be uncommon) }\end{array}$ \\
\hline & & high risk & $\begin{array}{l}\text { Not all of the study's pre-specified primary outcomes have been re- } \\
\text { ported; } \\
\text { One or more primary outcomes is reported using measurements, anal- } \\
\text { ysis methods or subsets of the data (e.g. subscales) that were not pre- } \\
\text { specified; } \\
\text { One or more reported primary outcomes were not pre-specified (unless } \\
\text { clear justification for their reporting is provided, such as an unexpected } \\
\text { adverse effect); } \\
\text { One or more outcomes of interest in the review are reported incom- } \\
\text { pletely so that they cannot be entered in a meta-analysis; } \\
\text { The study report fails to include results for a key outcome that would } \\
\text { be expected to have been reported for such a study }\end{array}$ \\
\hline & & unclear risk & Insufficient information to permit judgement of 'Yes' or 'No' \\
\hline & Independent funding source & low risk & Not sponsored by pharmaceutical industry \\
\hline & & high risk & Sponsored by pharmaceutical industry \\
\hline
\end{tabular}




\section{H I S T O R Y}

Protocol first published: Issue 1, 2009

Review first published: Issue 10, 2011

\begin{tabular}{l|ll}
\hline Date & Event & Description \\
\hline 13 May 2009 & Amended & The section "Criteria for considering studies for this review" has been amended \\
\hline 10 February 2009 & Amended & Search strategies \\
\hline 27 October 2008 & Amended & Converted to new review format. \\
\hline
\end{tabular}

\section{CONTRIBUTIONS OFAUTHORS}

Pucci, Giuliani, Solari, Simi and Minozzi drafted the protocol.

Pucci developed the search strategy.

Pucci, Giuliani and Solari performed screening of identified trials for possible inclusion.

Pucci and Galea extracted data from trials.

Pucci, Minozzi and Giuliani assessed methodological quality of each included trial.

Di Pietrantonj checked the extraction, structured the comparisons, entered the data into Review Manager (RevMan) 2008 and performed the analysis.

Pucci and Di Pietrantonj interpreted the analysis.

Pucci, Giuliani, Solari, Simi, Galea, Minozzi and Di Pietrantonj wrote the final report.

Pucci and Di Pietrantonj will update the review. 


\section{DECLARATIONSOF INTEREST}

Pucci has received funds from a non-profit association, the "Associazione Marchigiana sclerosi multipla e altre malattie neurologiche"; this association has received donations from Biogen Dompé, Merck-Serono and Bayer-Schering. In the last 5 years, Pucci has also received honoraria, reimbursement for attending congresses, and grant support for organising scientific activities from the abovementioned drug industries and from Aventis, UCB, Lundbeck and Novartis.

Solari has received research funding from Biogen Dompé and has also received consultancy payment from Merck-Serono.

Giuliani, Di Pietrantonj, Simi, Minozzi and Galea have no conflict of interests.

\section{SOURCES OF SUPPORT}

\section{Internal sources}

- Cochrane Vaccines Field - SSEpi / SeREMI - ASL Alessandria (Local Health Unit), Italy.

\section{External sources}

- Associazione Marchigiana Sclerosi Multipla e altre malattie neurologiche, Italy.

Travel expense reimbursement for meetings among the authors. Computer and Internet costs.

\section{DIFFERENCES BETWEEN PROTOCOLANDREVIEW}

In the protocol, we stated that "adverse event" did not include MS relapses. In the review we included MS relapses in AEs as the original trials did. Whenever possible, however, we analysed data including and excluding MS relapses.

Incidence of serious AE was moved from secondary outcomes to primary outcomes.

\section{N D EX TERMS}

\section{Medical Subject Headings (MeSH)}

Adjuvants, Immunologic [adverse effects; *therapeutic use]; Antibodies, Monoclonal [adverse effects; *therapeutic use]; Antibodies, Monoclonal, Humanized; Cell Migration Inhibition; Interferon-beta [ ${ }^{*}$ therapeutic use]; Multiple Sclerosis, Relapsing-Remitting [* drug therapy]; Peptides [adverse effects; *therapeutic use]; Randomized Controlled Trials as Topic

\section{MeSH check words}

Humans 